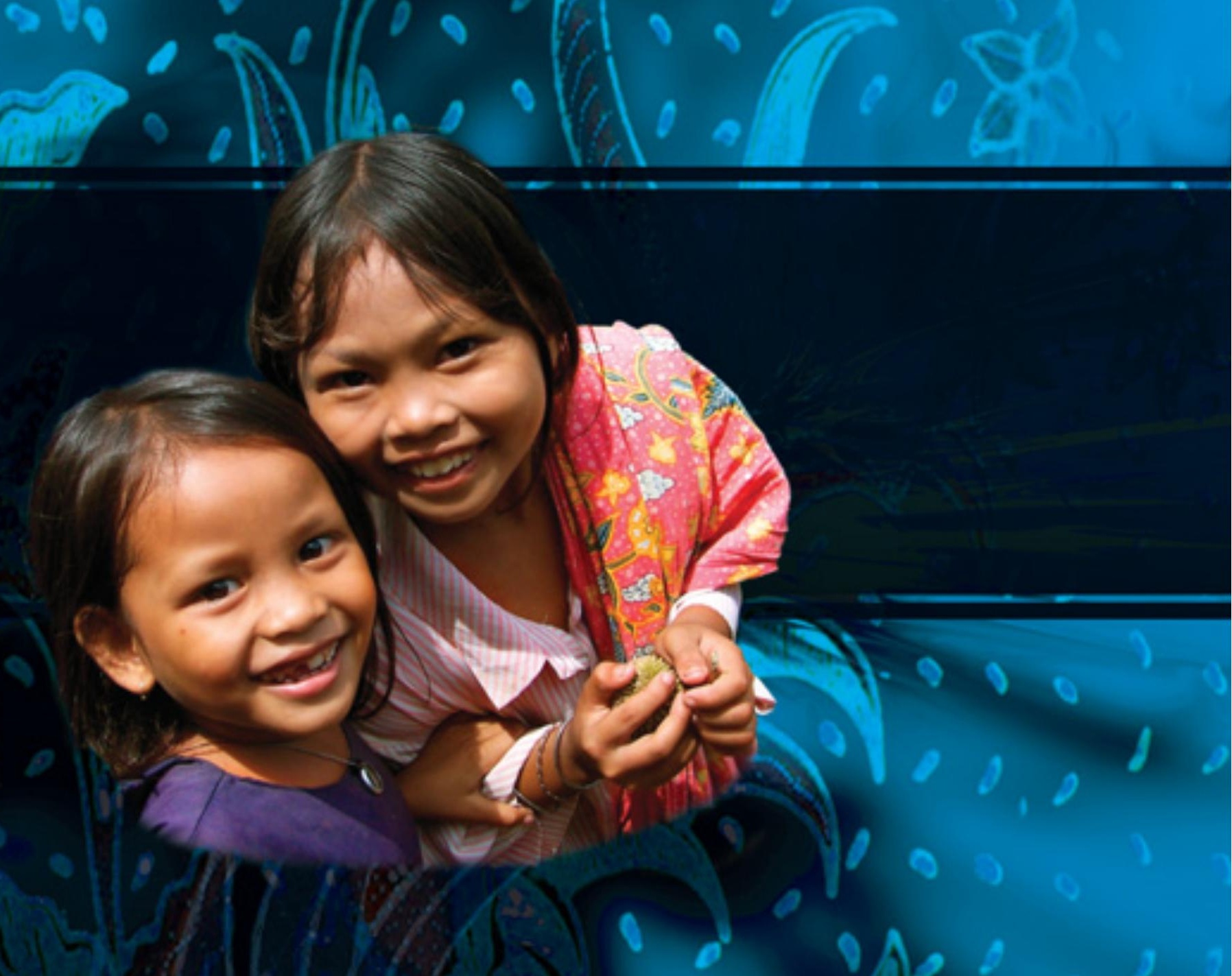

\title{
BELAJAR BERADAPTASI
}

\section{Bersama-sama Mengelola Hutan di Indonesia}

Trikurnianti Kusumanto, Elizabeth Linda Yuliani, Phil Macoun, Yayan Indriatmoko, dan Hasantoha Adnan 



\section{BELAJAR BERADAPTASI \\ Bersama-sama Mengelola Hutan di Indonesia}

Trikurnianti Kusumanto, Elizabeth Linda Yuliani, Phil Macoun, Yayan Indriatmoko, dan Hasantoha Adnan 


\section{BELAJAR BERADAPTASI \\ Bersama-sama Mengelola Hutan di Indonesia}

\section{Judul asli: \\ LEARNING TO ADAPT \\ Managing Forests Together in Indonesia}

Penulis: Trikurnianti Kusumanto, Elizabeth Linda Yuliani, Phil Macoun,

Yayan Indriatmoko, dan Hasantoha Adnan

Penyunting versi bahasa Indonesia: Ilya Moeliono

Tim alih bahasa: Riza Irfani, Paus Narutama Satya, dan Rianingsih Djohani

Dukungan editorial: Meilinda Wan

Desain Sampul: Edwin Yulianto

Tata letak: Catur Wahyu dan Vidya Fitrian

Ilustrasi: Deni Rodendo

Foto-foto: Hasantoha Adnan, Brian Belcher, Carol J.P. Colfer, Ismal Dobesto (PSHK-

ODA), Stepi Hakim, Yayan Indriatmoko, Trikurnianti Kusumanto, LATIN, Patrice Levang,

Marzoni (YGB), Muriadi, Parianto (PSHK-ODA), Yani Saloh, Plinio Sist, Herwasono

Soedjito, Eddy Harfia Surma (YGB), Tim ACM Jambi, Eva Wollenberg, dan Linda Yuliani

\section{Penerbit:}

Center for International Forestry Research (CIFOR)

Alamat Pos: P.O. Box 6596 JKPWB, Jakarta 10065, Indonesia

Alamat Kantor: Jalan CIFOR, Situ Gede, Sindang Barang,

Bogor Barat 16880, Indonesia

Telp.: +62 (0251) 622622. Fax.: +62 (0251) 622100

E-mail: cifor@cgiar.org

Situs web: http://www.cifor.cgiar.org

Pencetak:

SMK Grafika Desa Putera

(C) 2006 oleh CIFOR, Yayasan Gita Buana (YGB), dan Pusat Studi Hukum dan Kebijakan

Otonomi Daerah (PSHK-ODA)

Cetakan 1, Mei 2006

ISBN: 979-24-4615-X

Dengan dukungan dari:

- The Asian Development Bank (ADB)

- The Multistakeholder Forestry Programme (MFP), suatu program reformasi kehutanan yang dikelola bersama oleh Departemen Kehutanan R.I. dan the U.K. Department for International Development (DFID)

- The International Development Research Centre (IDRC)

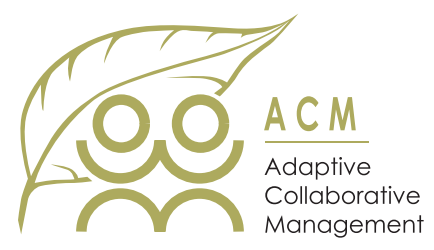




\section{DAFTAR ISI}

Daftar Kotak, Tabel, dan Gambar $\quad$ iv

Kata Pengantar vi

Ucapan Terima Kasih vii

Tentang Buku Ini $\quad$ ix

Daftar Istilah, Singkatan, dan Akronim $\quad$ xii

Bagian Satu: Pendahuluan 1

Bab 1. Perihal Penelitian ACM 3

Bab 2. Asal Usul ACM 9

Bagian Dua: Konteks 27

Bab 3. Pengelolaan Hutan Secara Kolaboratif di Indonesia 29

Bab 4. Lokasi Penelitian Kami 39

4.1. Hutan dan Para Pemangku Kepentingan 41

4.2. Konteks Pembelajaran: Menghadapi Ketidakpastian 51

4.3. Mengapa para Pemangku Kepentingan Kurang Mampu
Beradaptasi dan Berkolaborasi?

Bagian Tiga: Praktek $\quad 61$

Bab 5. Mempraktekkan ACM 63

5.1. Cara Kami Menciptakan Kondisi yang Memungkinkan Pembelajaran Multipihak $\quad 65$

5.2. Keluaran Pembelajaran 104

Bab 6. Tantangan, Keunggulan, dan Keterbatasan ACM 113

Bab 7. Hikmah Belajar 121

Bagian Empat: Implikasi dan Kesimpulan 127

Bab 8. Menerapkan ACM Secara Luas dalam Pengelolaan Hutan di Indonesia 129

Bab 9. Catatan Penutup 141

Lampiran $\quad 145$

Lampiran 1. Suatu Kerangka untuk Menerapkan ACM 147

Lampiran 2. Perangkat Alat Bantu ACM: Sebuah Contoh 177

Catatan Akhir 213

$\begin{array}{ll}\text { Daftar Pustaka } & 215\end{array}$ 


\section{DAFTAR KOTAK, TABEL, DAN GAMBAR}

\section{Kotak}

1. Sistem pengambilan keputusan secara top-down

2. Kelemahan pengelolaan secara kolaboratif yang sering terjadi

3. Definisi kami tentang kemampuan beradaptasi dan kemampuan berkolaborasi

4. Tiga proses umum yang terdapat dalam pendekatan ACM 18

5. Analisis pemangku kepentingan 19

6. Beberapa acuan dalam mengembangkan K\&I 22

7. Definisi fasilitasi 24

8. Pemangku kepentingan atas hutan 46

9. Para pemangku kepentingan di dalam masyarakat desa 46

10. Para pemangku kepentingan dari luar masyarakat desa 48

11. Ketidakpastian 51

12. Ketidakpastian tentang perilaku dan tindakan pihak lain 55

13. Ketidakpastian karena kebijakan 56

14. Mendefinisikan "pembelajaran" 65

15. Persepsi yang berbeda tentang permasalahan yang sama dengan pemecahan yang berbeda pula: Sebuah contoh dari Jambi 70

16. Proses mengidentifikasi pokok-pokok pembelajaran 70

17. Platform untuk mengorganisasikan pembelajaran 71

18. Membingkai kembali (reframe) beragam sudut pandang 73

19. Pokok-pokok pembelajaran yang diprioritaskan 74

20. Bersama-sama memetakan tata batas: Sebuah contoh pembelajaran berdasarkan pengalaman $\quad 79$

21. Meningkatkan pemerintahan desa: Contoh lain pembelajaran berdasarkan pengalaman $\quad 83$

22. Contoh-contoh prasangka (stereotyping) 91

23. Empat kebutuhan belajar para pemangku kepentingan: Beberapa contoh 96

24. Meningkatkan kemampuan strategis dalam bernegosiasi 97

25. Memotivasi para pemangku kepentingan untuk bersikap ingin tahu: $\begin{array}{ll}\text { Pembelajaran investigatif } & 98\end{array}$

26. Jangan cepat mengambil kesimpulan: Pembelajaran reflektif 99

27. Tiga cara memfasilitasi pembelajaran: Contoh dari Jambi 100

28. Tiga faktor yang menjadi motivasi para pemangku kepentingan untuk belajar bersama: Beberapa contoh 


\section{Tabel}

1. Contoh motivasi belajar para pemangku kepentingan dan peran fasilitasi

2. Keluaran ACM dari pembelajaran tentang tata batas desa: Contoh dari Pasir

3. Keluaran ACM dari pembelajaran tentang peningkatan pemerintahan desa: Contoh dari Jambi

\section{Gambar}

1. Peran ganda tim ACM dalam penelitian aksi partisipatif 7

2. Proses berulang-ulang pengelolaan adaptif 12

3. Menggabungkan ciri-ciri dua konsep untuk membentuk ACM 16

4. Langkah-langkah utama proses ACM 21

5. Berbagai peran fasilitasi dalam mengembangkan pembelajaran sosial 25

6. Rangkaian kesatuan kontinyu (continuum) dari partisipasi ke arah kolaborasi dalam pengelolaan hutan $\quad 35$

7. Lokasi-lokasi penelitian kami 42

8. Penurunan ketersediaan hasil hutan di kedua lokasi penelitian sebagaimana dilihat oleh para pemangku kepentingan desa 53

9. Tiga jenis kegiatan guna menciptakan kondisi pembelajaran 66

10. Dari identifikasi pokok-pokok permasalahan ke penentuan prioritasnya merupakan langkah yang BESAR

11. Menyeimbangkan kepemilikan individual dan kepemilikan kolektif atas pembelajaran

12. Dari banyak orang, sekelompok orang saja yang dipilih sebagai wakil untuk berpartisipasi

13. Menyelenggarakan pembelajaran bersama bagi para pemangku kepentingan dalam platform berjenjang (nested platforms)

14. Berbagai proses pembelajaran yang digunakan dalam memecahkan pokok permasalahan lokal

15. Siklus pembelajaran yang ditempuh para pemangku kepentingan dalam upaya penyelesaian masalah tata batas

16. Siklus pembelajaran untuk meningkatkan pemerintahan desa 87

17. Proses komunikasi yang terlihat sederhana

18. Bagaimananya pembelajaran para pemangku kepentingan:

Pembelajaran investigatif dan pembelajaran reflektif yang saling berurutan berulang-ulang

19. Sebuah gambar yang kami pakai untuk memicu diskusi di antara para pemangku kepentingan

20. Roda-roda perubahan karena pembelajaran sosial

21. Kaitan yang mungkin antara modal sosial sebagai "modal awal" dengan modal keuangan dan modal alam sebagai "modal terbentuk":

Contoh dari Pasir

22. Nilai tambah ACM terhadap strategi penghidupan 
Masyarakat Indonesia sangat menghargai hutan karena merupakan sumber pangan dan pendapatan bagi lebih dari seratus juta orang di daerah pedesaan dan perkotaan. Selain itu, hutan adalah dasar dari beragam kebudayaan dan kepercayaan yang menjadi kekayaan negeri ini. Walaupun begitu, di banyak tempat hutan telah diperlakukan dengan buruk. Tutupan hutan di negeri ini berkurang dengan cepat dan sumber daya hutan menghilang secara memprihatinkan. Di masa yang lalu, pemerintah, sektor nonpemerintah, masyarakat lokal, dan sektor kehutanan komersial telah mencoba berbagai program dan kebijakan untuk mengelola dan melindungi hutan, namun hasilnya masih sangat mengecewakan. Ada berbagai hal yang menghalangi usaha-usaha itu dan satu hal di antaranya memerlukan perhatian yang memadai dari kita semua: berbagai kelompok, organisasi, dan instansi yang bergiat di bidang kehutanan terlalu sombong untuk mengakui kekurangan mereka, sehingga hampir tidak ada upaya untuk saling belajar di antara mereka.

Ketika di tahun 2000 Center for International Forestry Research (CIFOR) meminta saya untuk menjadi anggota Panitia Penasihat Nasional dalam prakarsa penelitian tentang suatu pendekatan pengelolaan hutan yang disebut adaptive collaborative management (ACM), saya tidak dapat menolaknya. Saat itu kita berada dalam keadaan yang sarat dengan berbagai masalah mendesak. Masalahmasalah tersebut memerlukan segala upaya kita untuk dengan rendah hati belajar dari kekurangan masa lalu dan dari sesama kita guna membangun masa depan yang lebih baik bagi hutan dan masyarakat negeri ini.

Buku ini menawarkan kepada para pembaca suatu kesempatan untuk mengetahui pengalaman tim peneliti ACM Indonesia. Saya yakin bahwa pengalaman tim ini dapat menjadi sumber acuan bagi para praktisi, pengambil keputusan, dan peminat lainnya dalam mengembangkan strategi alternatif untuk pengelolaan hutan di Indonesia.

\section{Emil Salim}

Guru Besar Ekonomi di Universitas Indonesia dan Mantan Menteri Negara Kependudukan dan Lingkungan Hidup 


\section{UCAPAN TERIMA KASIH}

Banyak pihak berperan penting hingga buku ini dapat ditulis. Ucapan terima kasih kami sampaikan pertama-tama kepada masyarakat Baru Pelepat di Sumatera serta masyarakat Rantau Buta dan Rantau Layung di Kalimantan Timur. Rumah mereka telah menjadi tempat berteduh kami dan mereka telah banyak meluangkan waktu untuk memperbincangkan banyak hal bersama kami.

Selanjutnya kami menyampaikan apresiasi kami kepada staf LSM mitra CIFOREddy Harfia Surma, Marzoni, Effi Permata Sari, Budi Setiawan, dan Sutono dari Yayasan Gita Buana; Ahmad Albar, Ismal Dobesto, Helmi, Parianto, Dasril Rajab, dan Fauzi Syam dari Pusat Studi Hukum dan Kebijakan Otonomi Daerah; serta Amin Ja'far, Sarmiah, Suprihatin, dan Koesnadi Wiriasapoetra dari Yayasan Padi. Bersama mereka, kami telah menghabiskan banyak waktu dalam upaya bersama mendampingi kelompok-kelompok dan masyarakat di lokasi penelitian kami. Kami terutama berterimakasih atas persahabatan mereka.

Penelitian kami tidak mungkin terlaksana tanpa dukungan yang terus menerus dari BAPPEDA, Pemda, dan Dinas Kehutanan di Kabupaten Bungo, Propinsi Jambi di Sumatera, maupun dari BAPPEDA, Dinas Kehutanan, dan DPRD di Kabupaten Pasir, Kalimantan Timur. Di antara banyak pihak yang terlibat dalam penelitian kami, ucapan terima kasih kami sampaikan secara khusus kepada Iskandar Basri, Dewi, Mustafal Hadi, Budi Hartono, Usman Hasan, Dedy Irawan, Jasumbai, Mawardi, Ike Rachmawati, Safrizal, dan Iman Budi Setiawan di Bungo serta Muhamad Amin Ahmad, Abu Bakar Mahidin, Abdul Aziz Maulana, dan Romif di Pasir.

Penelitian kami di Sumatera dan Kalimantan Timur didanai oleh Bank Pembangunan Asia (ADB) sebagai bagian dari proyek CIFOR yang bernama Planning for Sustainability of Forests through Adaptive Co-Management (Perencanaan untuk Keberlanjutan Hutan melalui Pengelolaan Bersama secara Adaptif) yang dilaksanakan selama tahun 1999-2002. Namun demikian, penerbitan buku ini dapat terlaksana berkat dukungan dari Multistakeholder Forestry Programme (MFP), yang merupakan suatu program reformasi kehutanan yang dikelola bersama oleh Departemen Kehutanan R.I. dan U.K. Department for International Development (DFID) dari Inggris. Kami juga menyampaikan penghargaan kami kepada International Development Research Centre (IDRC) dari Kanada atas dukungannya terhadap sebagian dari kegiatan lapangan kami. Kami menyampaikan terima kasih kepada Muhammad A. Mannan dan Sivaguru Sahajananthan dari ADB dan Ivan Biot dari MFP atas dukungan mereka. 
Meskipun demikian, seluruh pandangan di dalam buku ini merupakan pemikiran tim penulis dan tidak mewakili pandangan serta kebijakan penyandangpenyandang dana tersebut.

Sebagai bagian dari penelitian ACM di tingkat global, tim kami sangat beruntung karena telah mendapat bimbingan intelektual dari International Steering Committee (Komite Pengarah Internasional). Ungkapan terima kasih yang tulus kami sampaikan kepada Peter Frost, Don Gilmour, Irene Guijt, Renato de Rueda, K.B. Shrestha, dan Yunita Winarto.

Di Indonesia, selama penelitian kami, tim kami mendapat banyak manfaat dari tinjauan kritis dan pandangan strategis yang diberikan oleh Komite Penasihat Nasional (National Advisory Committee): Erwidodo, Sandra Moniaga, Emil Salim, Djamaludin Suryohadikusumo, Trinugroho, dan Yunita Winarto. Pada saat menulis buku ini, penelitian kami telah memasuki tahapan baru dan kami menerima bimbingan dari Komite Pengarah Nasional (National Steering Committee) yang baru: Dani Wahyu Munggoro, Mustofa Agung Sardjono, Tetra Yanuariadi, dan Sih Yuniati. Kami berhutang budi kepada mereka semua.

Di CIFOR, Ravi Prabhu dan Carol J.P. Colfer tanpa bosan-bosannya membimbing tim kami baik dalam pemikiran maupun dalam pelaksanaan penelitian lapangan. Merupakan keberuntungan yang luar biasa bagi tim kami karena telah mendapat pengarahan dari mereka yang meletakkan dasar-dasar penelitian ACM di CIFOR. Kepada keduanya, kami berterimakasih secara mendalam. Kepada anggota tim ACM dari berbagai bagian dunia, terutama Herlina Hartanto dan Cynthia McDougall, kami menyampaikan terima kasih: mereka telah berbagi waktu, pemikiran, dan pandangan bersama kami. Terima kasih juga kepada Stepi Hakim, anggota tim Indonesia yang bertanggung jawab atas penelitian di Pasir dan dengan demikian memberi kontribusi yang penting terhadap penelitian ini, tetapi tidak sempat bergabung pada saat kami menulis buku ini.

Dalam mengembangkan buku ini, tinjauan kritis terhadap draft naskah buku ini diberikan oleh Carol Colfer, Ravi Prabhu, dan Moira Moeliono dari CIFOR, serta Dani Wahyu Munggoro dan Tetra Yanuriadi dari Komite Pengarah Nasional. Kami sangat berterimakasih untuk masukan-masukan kritis mereka. Sebagai bagian dari rangkaian penerbitan tentang penelitian ACM di Asia, tata letak buku ini mengikuti versi Filipina dengan beberapa perubahan kecil di sana sini. Karenanya, kami ucapkan terima kasih kepada tim ACM Filipina atas penggunaan rancangan tata letak mereka untuk buku ini. Akhirnya, terima kasih juga kami ucapkan kepada Gideon Suharyanto, Rahayu Koesnadi, Atie Puntodewo, dan Ahmad Yusuf atas bantuannya dalam proses produksi buku ini. 


\section{TENTANG BUKU INI}

\section{Apa Tujuan Buku Ini?}

Buku ini dimaksudkan untuk membantu staf proyek dan para fasilitator lapangan dalam mendampingi masyarakat dan lembaga lokal berkaitan dengan pengelolaan hutan. Buku ini menyarikan pengalaman tim peneliti CIFOR dan pendampingpendamping masyarakat serta staf lainnya dari tiga LSM mitranya ${ }^{1}$ di Indonesia, selanjutnya disebut tim.

Tim tersebut melaksanakan penelitian aksi partisipatif tentang suatu pendekatan yang disebut adaptive collaborative management (ACM). Apabila pendekatan ini diterjemahkan ke dalam bahasa Indonesia, kita dapat menggunakan istilah "pengelolaan bersama secara adaptif" (PBA). Walaupun demikian, buku ini menggunakan istilah dalam bahasa Inggris untuk menghindari kerancuan, mengingat berbagai istilah, singkatan, ataupun akronim yang berkenaan dengan pengelolaan hutan banyak bermunculan dewasa ini di Indonesia. Meskipun begitu, dalam merujuk pada pendekatan ini, pembaca tentu memiliki kebebasan dalam memilih penggunaan bahasa yang dipandangnya tepat untuk konteks kegiatannya.

Proses penelitian berlangsung dari tahun 2000 sampai 2002 dan dilaksanakan di dua lokasi di Indonesia, yaitu di Propinsi Jambi di Sumatera dan Propinsi Kalimantan Timur.

Penelitian serupa dilaksanakan juga di Bolivia, Brasilia, Filipina, Gana, Kamerun, Kirgistan, Madagaskar, Malawi, Nepal, dan Zimbabwe. Sama seperti penelitian di Filipina dan Nepal, Bank Pembangunan Asia (ADB) membiayai penelitian yang dilaksanakan di Indonesia.

Buku ini dimaksudkan untuk berbagi pengalaman dan temuan-temuan yang diperoleh dari penelitian ACM di Indonesia.

\section{Apa yang Ada Dalam Buku Ini?}

Buku ini memadukan pengalaman konkret tim dengan konsep-konsep abstrak tentang pendekatan ACM yang berkembang sewaktu diterapkan di lapangan. Buku ini dibagi ke dalam empat bagian sebagai berikut: 


\section{Bagian Pertama: Pendahuluan}

Bab 1 menyampaikan tinjauan umum tentang apa yang dimaksudkan dengan penelitian tentang ACM dan mengangkat pertanyaan-pertanyaan penelitian yang ingin dicari jawabannya.

Bab 2 membahas asal muasal ACM sebagai sebuah pendekatan dan menyajikan latar belakang pendekatan ACM secara teoretis.

\section{Bagian Kedua: Konteks}

Bab 3 merinci perkembangan berbagai bentuk partisipasi dalam konteks pengelolaan hutan serta tantangan-tantangan yang dihadapinya, dengan perhatian khusus pada "pengelolaan hutan secara kolaboratif" di Indonesia.

Bab 4 menggambarkan lokasi penelitian ACM dan membahas hasil kajian tim tentang mengapa di lokasi-lokasi tersebut kurang terjadi kolaborasi dan adaptasi pada saat penelitian dimulai.

\section{Bagian Tiga: Praktek}

Bab 5 menyampaikan pengalaman tim dalam menerapkan pendekatan ACM dalam mendampingi pemangku-pemangku kepentingan lokal untuk meningkatkan sumber penghidupannya.

Bab 6 merinci tantangan yang dihadapi tim ketika menerapkan ACM, diikuti dengan pembahasan mengenai keunggulan dan keterbatasan ACM sebagaimana dialami tim.

Bab 7 menyajikan pelajaran yang diperoleh dari penelitian aksi partisipatif (participatory action research (PAR)) mengenai ACM.

\section{Bagian Empat: Implikasi dan Kesimpulan}

Bab 8 membahas implikasi dari hasil penelitian tim terhadap program-program kehutanan di Indonesia.

Bab 9 menawarkan kesimpulan yang dapat ditarik dari pelaksanaan penelitian tentang pendekatan ACM di Indonesia.

Selanjutnya, Lampiran 1 dan Lampiran 2 menyajikan secara berturut-turut suatu kerangka untuk menerapkan ACM dan sebuah contoh kumpulan alat bantu yang dapat digunakan dalam menerapkan pendekatan ini. 


\section{Siapa yang Dapat Menggunakan Buku Ini?}

Buku ini ditujukan bagi para pendamping masyarakat lokal, staf organisasi dan instansi yang bekerja di lapangan seperti staf LSM dan petugas penyuluh instansi pemerintah (terutama dari dinas kehutanan), para pelatih, dan pembaca lainnya yang berminat. Karena setiap hari berhubungan dengan masyarakat, kelompokkelompok, dan pemangku kepentingan lokal lainnya dalam pengelolaan sumber daya alam, mereka dapat menggunakan buku ini sebagai bahan acuan, sebagai "alat bantu" dalam memfasilitasi aksi oleh pemangku kepentingan lokal, atau sekedar sebagai catatan pengalaman tim.

Buku ini disusun sedemikian rupa agar semua bagian di dalamnya bisa dibaca secara berurutan, seperti sebuah cerita, ataupun dibaca bagian-bagian tertentu saja sebagai dasar pemikiran untuk mengembangkan metode, "alat bantu", atau konsep pengelolaan hutan yang baru. Harapannya, pembaca tidak hanya senang membaca buku ini, tetapi juga akan terilhami untuk mencari cara-cara baru dalam mendampingi pemangku kepentingan lokal dalam mengelola hutan secara bersama. 


\section{DAFTAR ISTILAH, SINGKATAN, DAN AKRONIM}

\begin{tabular}{|c|c|c|}
\hline $\begin{array}{l}\text { Istilah/Singkatan/ } \\
\text { Akronim }\end{array}$ & Bahasa Indonesia & Bahasa Inggris \\
\hline 4Rs framework & $\begin{array}{l}\text { kerangka tanggung jawab, } \\
\text { hak, hasil, dan hubungan } \\
\text { (TH3) }\end{array}$ & $\begin{array}{l}\text { rights, responsibilities, } \\
\text { returns, and relationships }\end{array}$ \\
\hline $\mathrm{ACM}$ & $\begin{array}{l}\text { pengelolaan bersama secara } \\
\text { adaptif (PBA) }\end{array}$ & $\begin{array}{l}\text { adaptive collaborative } \\
\text { management }\end{array}$ \\
\hline $\mathrm{ADB}$ & Bank Pembangunan Asia & Asian Development Bank \\
\hline BAPPEDA & $\begin{array}{l}\text { Badan Perencanaan } \\
\text { Pembangunan Daerah }\end{array}$ & - \\
\hline $\mathrm{BPD}$ & Badan Perwakilan Desa & - \\
\hline C\&I & $\begin{array}{l}\text { kriteria dan indikator } \\
(K \& I)\end{array}$ & criteria and indicators \\
\hline CBFM & $\begin{array}{l}\text { Pengelolaan Hutan } \\
\text { Berbasis Masyarakat } \\
(\text { PHBsM) }\end{array}$ & $\begin{array}{l}\text { Community-Based Forest } \\
\text { Management }\end{array}$ \\
\hline CIFOR & $\begin{array}{l}\text { Pusat Penelitian } \\
\text { Kehutanan Internasional } \\
\text { (suatu organisasi } \\
\text { internasional, bermarkas } \\
\text { besar di Bogor, Indonesia) }\end{array}$ & $\begin{array}{l}\text { Center for International } \\
\text { Forestry Research }\end{array}$ \\
\hline DFID & $\begin{array}{l}\text { Departemen Pembangunan } \\
\text { Internasional Kerajaan } \\
\text { Inggris }\end{array}$ & $\begin{array}{l}\text { UK Department for } \\
\text { International Development }\end{array}$ \\
\hline Dishut & $\begin{array}{l}\text { Dinas kehutanan (tingkat } \\
\text { propinsi/kabupaten) }\end{array}$ & - \\
\hline Dis-PTK & $\begin{array}{l}\text { Dinas pertanian dan } \\
\text { tanaman keras (tingkat } \\
\text { propinsi/kabupaten) }\end{array}$ & - \\
\hline DPRD & $\begin{array}{l}\text { Dewan Perwakilan Rakyat } \\
\text { Daerah (tingkat propinsi/ } \\
\text { kabupaten) }\end{array}$ & - \\
\hline $\mathrm{FAO}$ & $\begin{array}{l}\text { Organisasi Pangan dan } \\
\text { Pertanian Perserikatan } \\
\text { Bangsa-Bangsa } \\
\text { diskusi kelompok terfokus }\end{array}$ & $\begin{array}{l}\text { Food and Agriculture } \\
\text { Organization of the United } \\
\text { Nations } \\
\text { focus group discussion }\end{array}$ \\
\hline
\end{tabular}




\begin{tabular}{|c|c|c|}
\hline $\begin{array}{l}\text { Istilah/Singkatan/ } \\
\text { Akronim }\end{array}$ & Bahasa Indonesia & Bahasa Inggris \\
\hline GPS & $\begin{array}{l}\text { sistem penentuan posisi } \\
\text { global }\end{array}$ & global positioning system \\
\hline $\mathrm{HKm}$ & $\begin{array}{l}\text { Program Hutan } \\
\text { Kemasyarakatan }\end{array}$ & $\begin{array}{l}\text { Community Forestry } \\
\text { Programme }\end{array}$ \\
\hline $\mathrm{HPH}$ & hak pengusahaan hutan & - \\
\hline ICDP & $\begin{array}{l}\text { Proyek Konservasi dan } \\
\text { Pembangunan secara } \\
\text { Terpadu }\end{array}$ & $\begin{array}{l}\text { Integrated Conservation } \\
\text { and Development Project }\end{array}$ \\
\hline IDRC & $\begin{array}{l}\text { Pusat Penelitian } \\
\text { Pembangunan } \\
\text { Internasional (suatu } \\
\text { instansi pemerintah } \\
\text { Kanada) }\end{array}$ & $\begin{array}{l}\text { International Development } \\
\text { Research Centre }\end{array}$ \\
\hline IIED & $\begin{array}{l}\text { Lembaga Internasional } \\
\text { untuk Lingkungan dan } \\
\text { Pembangunan (suatu } \\
\text { lembaga nonpemerintah } \\
\text { Inggris) }\end{array}$ & $\begin{array}{l}\text { International Institute } \\
\text { for Environment and } \\
\text { Development }\end{array}$ \\
\hline IPPK & $\begin{array}{l}\text { Izin Pemungutan dan } \\
\text { Pemanfaatan Kayu }\end{array}$ & - \\
\hline K\&I & Kriteria dan Indikator & $\begin{array}{l}\text { criteria and indicators } \\
\text { (C\&I) }\end{array}$ \\
\hline KdTI & $\begin{array}{l}\text { Kawasan dengan Tujuan } \\
\text { Istimewa }\end{array}$ & - \\
\hline LATIN & $\begin{array}{l}\text { Lembaga Alam Tropika } \\
\text { Indonesia (suatu LSM) }\end{array}$ & - \\
\hline LSM & $\begin{array}{l}\text { Lembaga Swadaya } \\
\text { Masyarakat }\end{array}$ & $\begin{array}{l}\text { nongovernmental } \\
\text { organisation }\end{array}$ \\
\hline MFP & $\begin{array}{l}\text { Program Kehutanan } \\
\text { Multipihak (suatu program } \\
\text { reformasi kehutanan yang } \\
\text { dikelola bersama oleh } \\
\text { Departemen Kehutanan } \\
\text { R.I. dan DFID) }\end{array}$ & $\begin{array}{l}\text { Multistakeholder Forestry } \\
\text { Programme }\end{array}$ \\
\hline NGO & $\begin{array}{l}\text { organisasi nonpemerintah/ } \\
\text { lembaga swadaya } \\
\text { masyarakat }\end{array}$ & $\begin{array}{l}\text { nongovernmental } \\
\text { organisation }\end{array}$ \\
\hline PAR & penelitian aksi partisipatif & $\begin{array}{l}\text { participatory action } \\
\text { research }\end{array}$ \\
\hline PBA & $\begin{array}{l}\text { pengelolaan bersama secara } \\
\text { adaptif }\end{array}$ & $\begin{array}{l}\text { adaptive collaborative } \\
\text { management (ACM) }\end{array}$ \\
\hline
\end{tabular}




\begin{tabular}{|c|c|c|}
\hline $\begin{array}{l}\text { Istilah/Singkatan/ } \\
\text { Akronim }\end{array}$ & Bahasa Indonesia & Bahasa Inggris \\
\hline PCSPP & $\begin{array}{l}\text { Pengkajian Cepat System } \\
\text { Pengetahuan Pertanian }\end{array}$ & $\begin{array}{l}\text { Rapid Assessment of } \\
\text { Agricultural Knowledge } \\
\text { Systems (RAAKS) }\end{array}$ \\
\hline Pemda & Pemerintah Daerah & 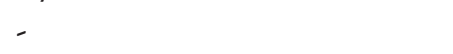 \\
\hline PHB & $\begin{array}{l}\text { pengelolaan hutan } \\
\text { berkelanjutan }\end{array}$ & $\begin{array}{l}\text { sustainable forest } \\
\text { management (SFM) }\end{array}$ \\
\hline PHBM & $\begin{array}{l}\text { Pengelolaan Hutan } \\
\text { Bersama Masyarakat }\end{array}$ & $\begin{array}{l}\text { Collaborative Forest } \\
\text { Management }\end{array}$ \\
\hline PHBsM & $\begin{array}{l}\text { Pengelolaan Hutan } \\
\text { Berbasis Masyarakat }\end{array}$ & $\begin{array}{l}\text { Community-Based Forest } \\
\text { Management (CBFM) }\end{array}$ \\
\hline PMDH & $\begin{array}{l}\text { Program Pembinaan } \\
\text { Masyarakat Desa Hutan }\end{array}$ & - \\
\hline PRA & $\begin{array}{l}\text { pengkajian pedesaan secara } \\
\text { partisipatif }\end{array}$ & participatory rural appraisal \\
\hline PSHK-ODA & $\begin{array}{l}\text { Pusat Studi Hukum dan } \\
\text { Kebijakan Otonomi } \\
\text { Daerah (salah satu lembaga } \\
\text { mitra CIFOR) }\end{array}$ & $\begin{array}{l}\text { Study Center for Regional } \\
\text { Autonomy, Law and Policy }\end{array}$ \\
\hline PT & $\begin{array}{l}\text { perseroan terbatas (suatu } \\
\text { bentuk perusahaan) }\end{array}$ & limited company (ltd.) \\
\hline RAAKS & $\begin{array}{l}\text { Pengkajian Cepat Sistem } \\
\text { Pengetahuan Pertanian } \\
\text { (PCSPP) }\end{array}$ & $\begin{array}{l}\text { Rapid Appraisal of } \\
\text { Agricultural Knowledge } \\
\text { Systems }\end{array}$ \\
\hline RECOFTC & $\begin{array}{l}\text { Pusat Pelatihan Hutan } \\
\text { Kemasyarakatan untuk } \\
\text { Asia dan Pasifik (suatu } \\
\text { lembaga internasional, } \\
\text { berkedudukan di Thailand) }\end{array}$ & $\begin{array}{l}\text { Regional Community } \\
\text { Forestry Training Center for } \\
\text { Asia and the Pacific }\end{array}$ \\
\hline SFM & $\begin{array}{l}\text { pengelolaan hutan } \\
\text { berkelanjutan (PHB) }\end{array}$ & $\begin{array}{l}\text { sustainable forest } \\
\text { management }\end{array}$ \\
\hline TH3 & $\begin{array}{l}\text { kerangka tanggung jawab, } \\
\text { hak, hasil, dan hubungan }\end{array}$ & $\begin{array}{l}\text { rights, responsibilities, } \\
\text { returns, and relationships } \\
\text { (4Rs framework) }\end{array}$ \\
\hline ToT & $\begin{array}{l}\text { pelatihan untuk para } \\
\text { pelatih }\end{array}$ & training of trainers \\
\hline UK & Kerajaan Inggris & The United Kingdom \\
\hline YGB & $\begin{array}{l}\text { Yayasan Gita Buana } \\
\text { (salah satu lembaga mitra } \\
\text { CIFOR) }\end{array}$ & - \\
\hline
\end{tabular}




\section{Bagian Satu}

\section{Pendahuluan}

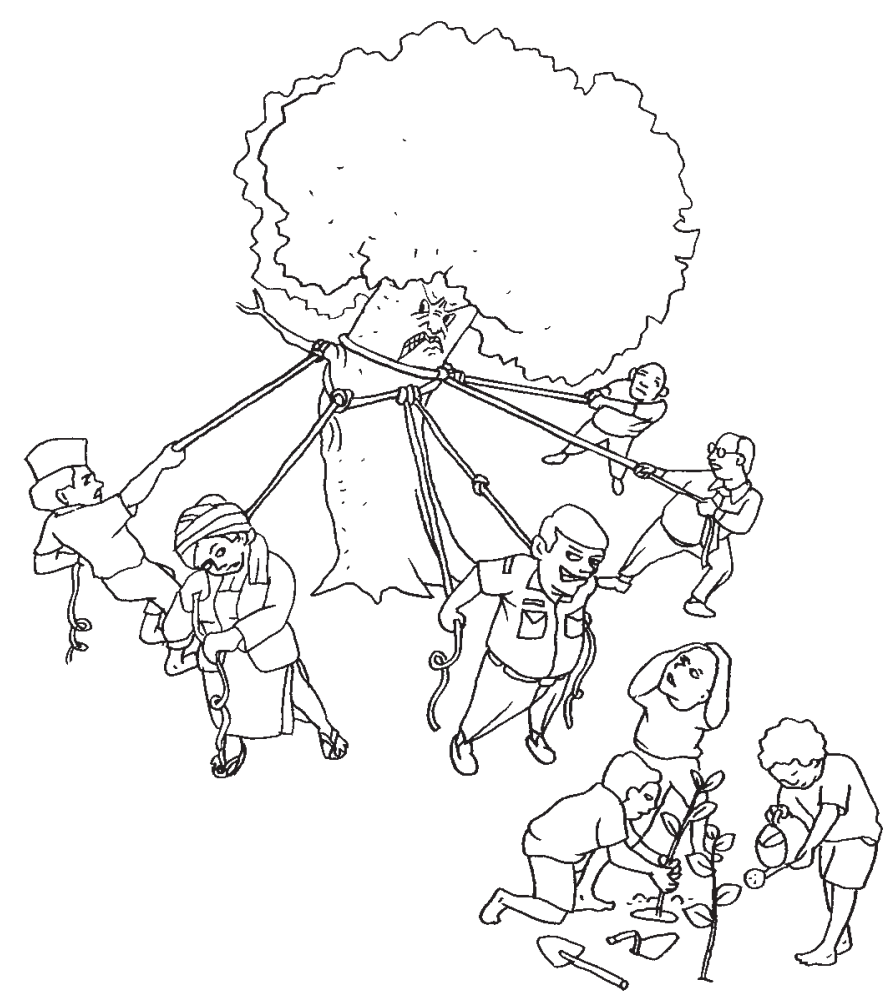

Di berbagai tempat di dunia ada kebutuhan yang kian meningkat untuk memperbaiki pengelolaan hutan. Kebutuhan ini sering muncul karena perbedaan pandangan antara pemangku-pemangku kepentingan yang menggunakan tanah hutan dan sumber daya hutan yang sama. Meskipun secara umum diterima bahwa permasalahan ini harus diselesaikan melalui kerja sama di antara kelompok-kelompok yang bersaing, masih terdapat banyak pertanyaan mengenai bagaimana mempraktekkannya. Buku ini mencoba menjawab sebagian dari pertanyaan tersebut.

Bagian Satu merupakan pengantar: Bab 1 memberikan gambaran umum tentang apa yang dimaksud dengan penelitian ACM, serta memaparkan pertanyaan-pertanyaan yang ingin kami cari jawabannya, sementara Bab 2 memperinci asal muasal konsep ACM. 



\section{PERIHAL PENELITIAN ACM}

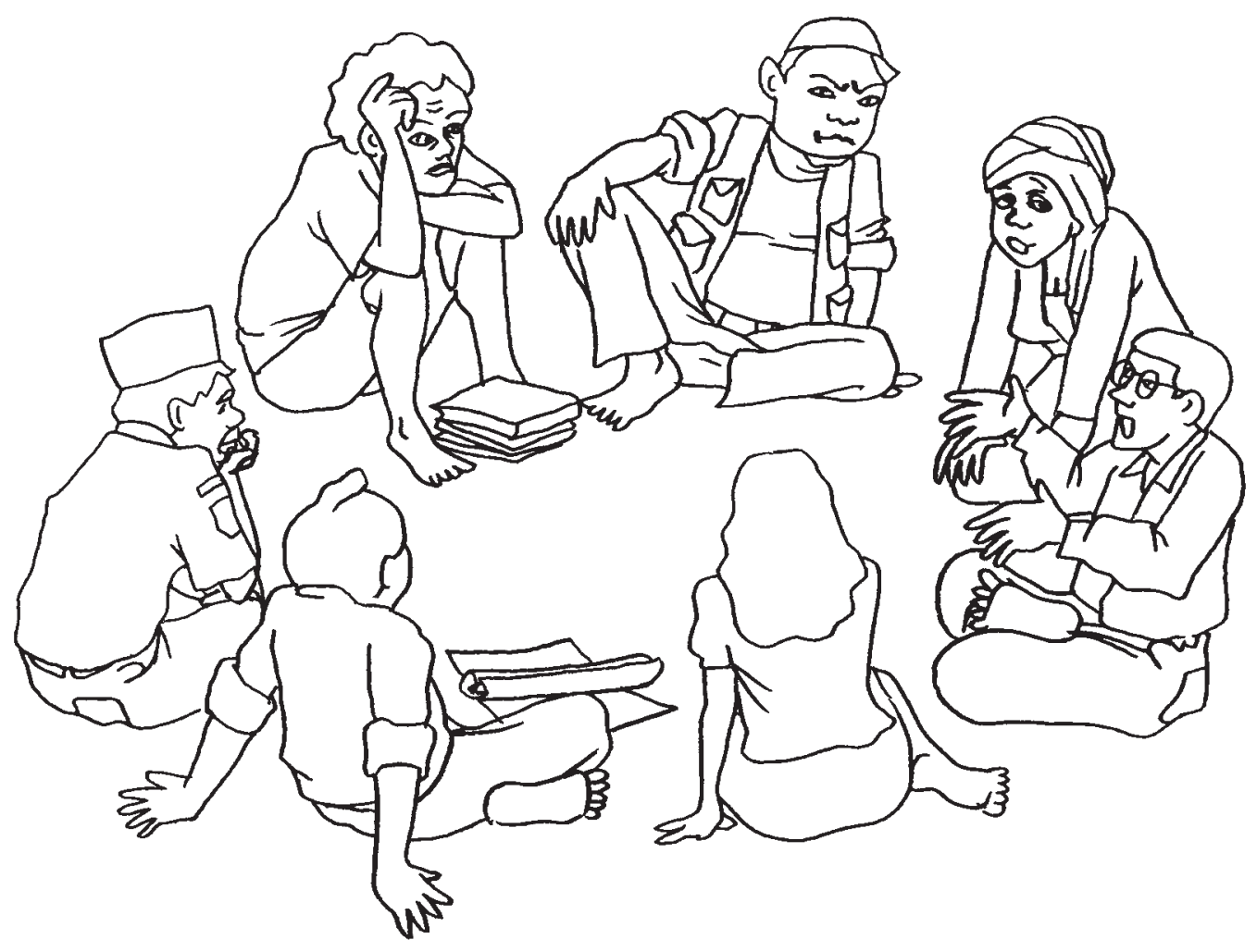


Nyaris tidak dapat dipercaya jika semua hal adalah seperti nampaknya, jika tidak ada rahasia tersembunyi.

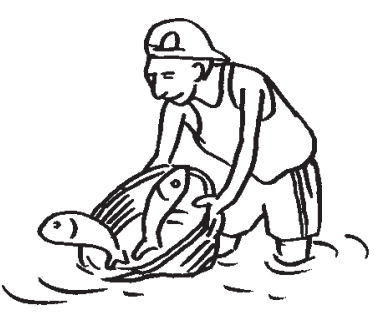

(It is incredible, that is, if things are what they seem, if there is not a secret hidden somewhere.)

Rebecca West, wartawati, dalam "The Strange Necessity" 1926 
Pada awal tahun 2000, ketika para peneliti dari berbagai belahan dunia berkumpul di CIFOR untuk membentuk Kelompok Peneliti ACM (ACM Group), Indonesia sedang mengalami goncangan sosial yang cukup hebat. Krisis ekonomi pada tahun-tahun sebelumnya, jatuhnya kepemimpinan autokratis Soeharto secara dramatis dua tahun sebelumnya, dan kekecewaan masyarakat yang terpendam terhadap pemerintahan yang korup telah mendorong proses-proses perubahan tersebut. Gelombang perubahan yang kemudian terjadi dirasakan di semua tingkatan masyarakat.

Ketika perubahan-perubahan itu terus bergulir, meluas serta mulai menyentuh ranah kehutanan Indonesia, terbukalah berbagai peluang upaya perbaikan pengelolaan hutan. Hal ini penting karena sudah begitu lama hutan di Indonesia dikelola dengan cara yang tidak adil, tidak berkelanjutan, dan hanya menguntungkan segelintir kelompok tertentu yang diistimewakan negara.

Sebagai bagian dari Kelompok Peneliti ACM internasional yang baru terbentuk itu, tim Indonesia berpandangan bahwa tidak ada saat yang lebih tepat untuk memulai penelitian ACM ini. Pertanyaan yang menarik bagi tim adalah, ketika banyak peluang untuk terjadinya perubahan muncul di Indonesia, ke manakah arah perubahan yang akan terjadi?

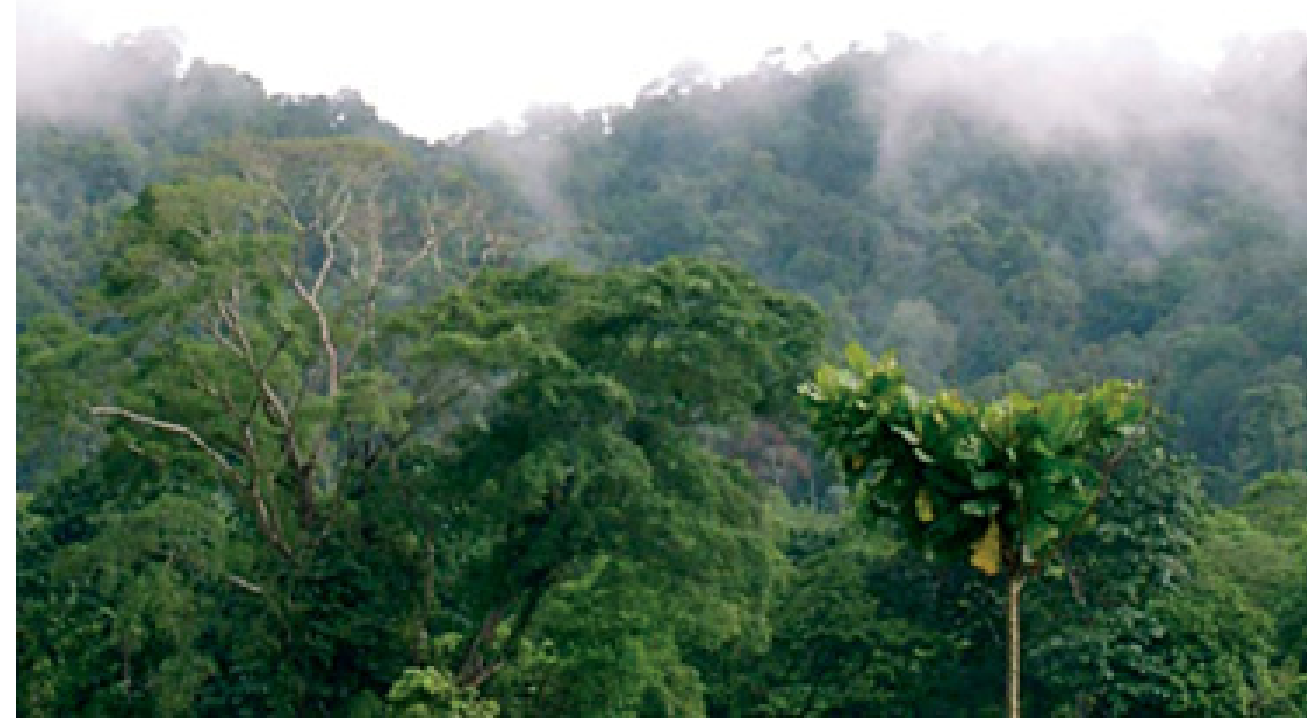

Hutan yang tersisa di Jambi, Sumatera, sebagaimana diperlihatkan di sini adalah keadaan umum yang dapat diamati di seluruh Indonesia. 
Dalam semangat demokratisasi yang berkembang, arah perubahan itu semestinya menjadi hasil dari keputusan bersama dan tindakan bersama. Tetapi selama ini pembelajaran bersama antara berbagai pemangku kepentingan dalam pengelolaan hutan di Indonesia sangat kurang. Keadaan itu tidak mendorong kolaborasi, ataupun memicu kelompok-kelompok yang berkepentingan terhadap hutan untuk secara bersama dan bertanggung jawab memanfaatkan dan mengelola hutan.

Tim kami berkeyakinan bahwa kolaborasi dan pembelajaran merupakan hal yang mendesak di Indonesia. Meskipun memang banyak perubahan terjadi yang kemudian merangsang berbagai kelompok untuk mengajukan tuntutannya masing-masing terhadap hutan, sangatlah sulit untuk diketahui apakah perubahanperubahan itu akan bergerak demi kebaikan hutan dan masyarakat, atau justru sebaliknya.

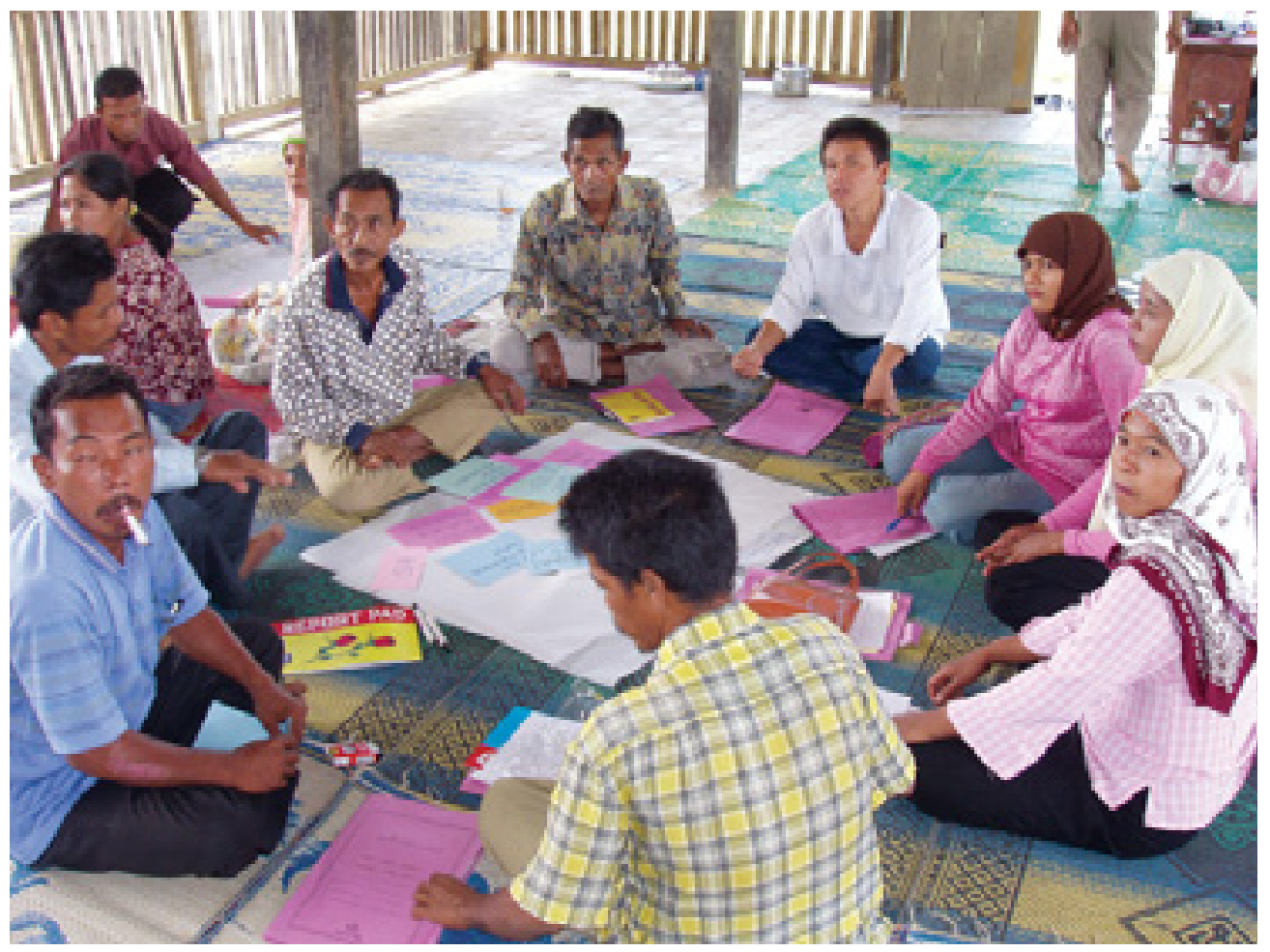

Kelompok-kelompok lokal bertindak sebagai peneliti aksi, berdampingan dengan tim kami sepanjang proses penelitian aksi.

Tim kami berharap ACM dapat menawarkan kepada para pemangku kepentingan sarana pembelajaran bersama sebagai dasar untuk memperbaiki secara kolaboratif strategi-strategi pengelolaan hutan. Dengan penelitian ACM, kami mencari jawaban atas tiga pertanyaan berikut: 
1. Dapatkah kerja sama di antara para pemangku kepentingan dalam pengelolaan hutan diperkuat oleh proses pembelajaran sosial yang kemudian dapat meningkatkan kesejahteraan masyarakat dan memperbaiki kondisi hutan?

2. Pendekatan-pendekatan apakah yang terfokus pada pembelajaran sosial dan aksi kolaboratif antara para pemangku kepentingan yang dapat mendorong pengelolaan hutan yang berkelanjutan?

3. Bagaimanakah pembelajaran sosial dalam ACM mempengaruhi fungsi sosial, ekonomi, dan ekologi?

Penelitian kami menggunakan penelitian aksi partisipatif (participatory action research (PAR)) sebagai metodologi penelitian. Ini berarti ada dua hal yang kami lakukan: kami mengamati apa yang dilakukan orang lain terhadap hutan, dan pada saat yang sama kami mencari tahu bagaimana keadaan hutan dapat ditingkatkan. Dengan demikian, tim kami bersama kelompok-kelompok lokal bertindak sebagai peneliti-peneliti aksi. Hal ini merupakan pengalaman baru bagi kami dalam melakukan penelitian.

Kami melakukan penelitian aksi partisipatif pada dua "lapisan" (lihat Gambar 1). Di lapisan dalam, tim kami memfasilitasi berbagai pemangku kepentingan untuk berkolaborasi dan belajar bersama, sementara di lapisan luar kami mengamati proses kolaborasi dan pembelajaran, yang terjadi di lapisan dalam. Pada saatsaat tertentu kami menempatkan diri kami di lapisan dalam sebagai fasilitator pembelajaran. Sementara pada kesempatan lain kami berada di lapisan luar sebagai pengamat.

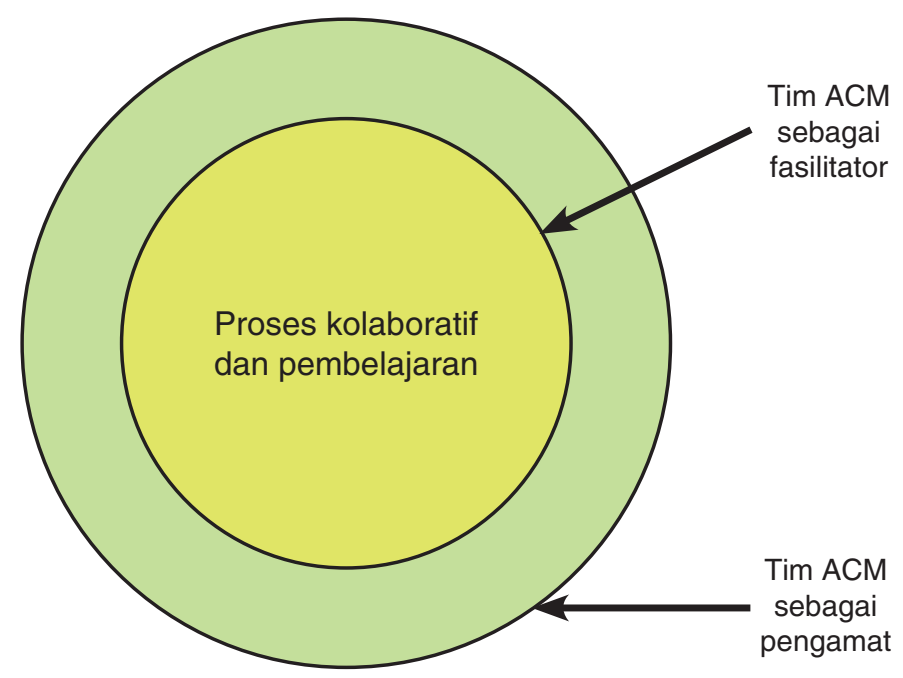

Gambar 1. Peran ganda tim ACM dalam penelitian aksi partisipatif 



\section{ASAL USUL ACM}

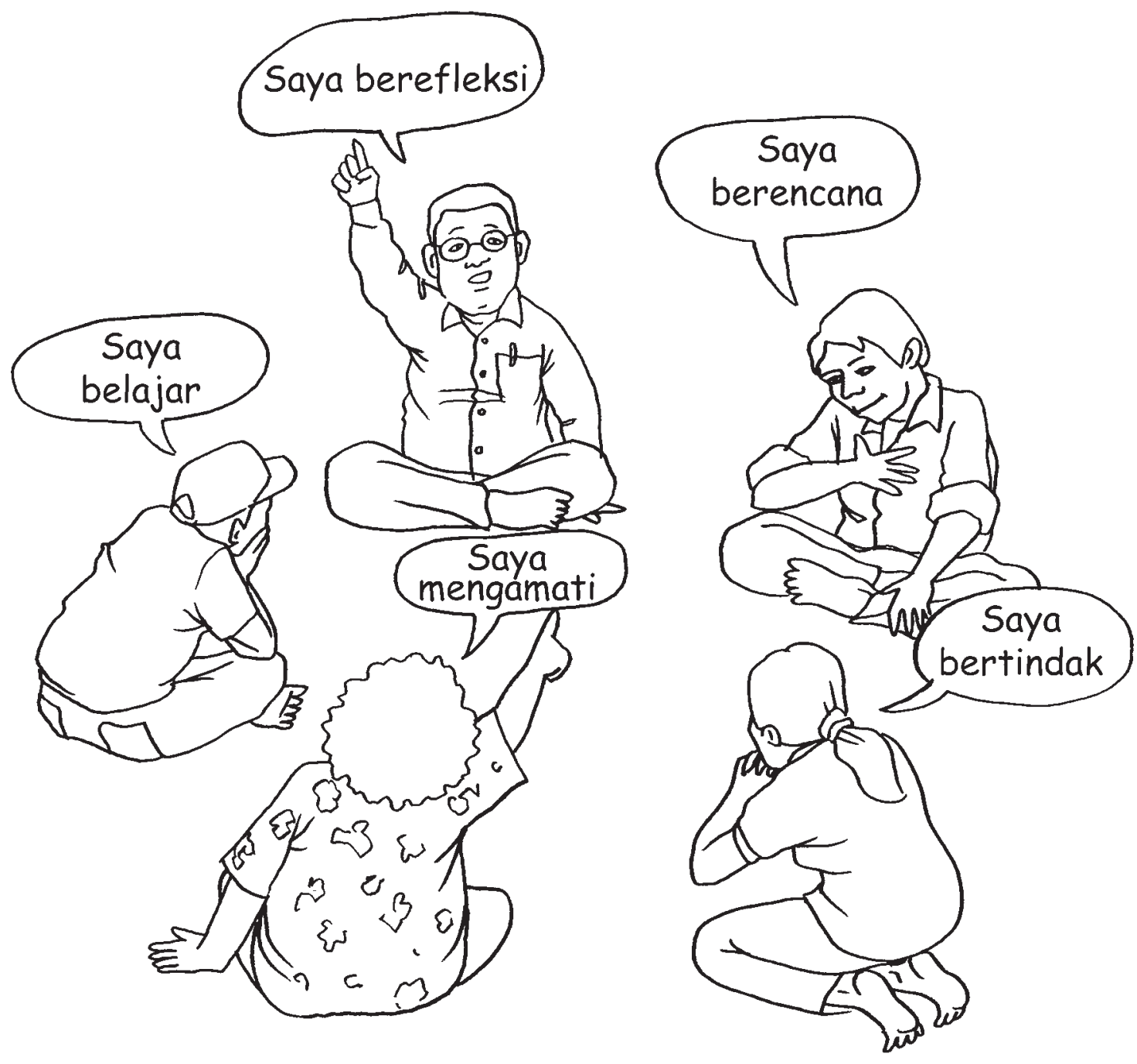




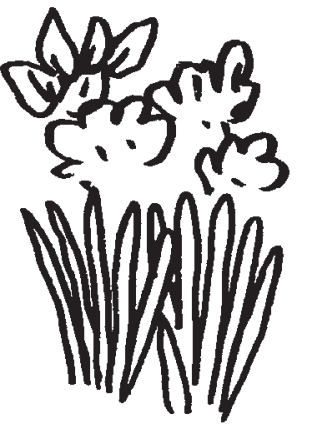

Akhirnya eukariot mempelajari suatu kiat baru yang mengesankan. Hal itu membutuhkan waktu yang lamakurang-lebih semilyar tahun - tetapi setelah dikuasai ternyata kiat yang baik. Mereka belajar untuk bersamasama membentuk makhluk multisel yang kompleks. Berkat inovasi ini, kesatuan yang besar, rumit, dan nampak nyata seperti kita menjadi mungkin. Planet Bumi siap untuk bergerak ke tahapan ambisius berikutnya.

(Eventually the eukaryotes learned an even more singular trick. It took a long timea billion years or so-but it was a good one when they mastered it. They learned to form together into complex multicellular beings. Thanks to this innovation, big, complicated, visible entities like us were possible. Planet Earth was ready to move on to its next ambitious phase.)

Bill Bryson, dalam "A Short History of Nearly Everything”, buku yang memenangkan hadiah Aventis untuk buku-buku ilmu pengetahuan, 2004 
Pendekatan ACM adalah suatu proses yang bertujuan mendorong para pemangku kepentingan untuk bekerja sama dalam merencanakan, melaksanakan, mengamati, dan mengambil pelajaran dari pelaksanaan rencana mereka di masa lalu. Untuk adanya gambaran yang memadai tentang ACM, proses-proses, dan unsurunsur kuncinya, kita perlu mencermati asal muasal ACM, yakni pengelolaan adaptif dan pengelolaan bersama/kolaboratif.

Dalam bab ini, kami akan menggambarkan ciri dari masing-masing konsep di atas dan menjelaskan apa dan bagaimana kami menggabungkannya. Selain itu, kami akan mencoba menjelaskan secara sederhana teori-teori yang mendasari pendekatan ACM, termasuk komponen-komponen inti dan proses-proses yang menjadi "jiwa" pendekatan ini, maupun gambaran tentang bagaimana ACM dapat diterapkan.

\section{ADAPTIF}

dari "adaptasi", proses mengadaptasi atau menyesuaikan dengan kondisi yang baru.

\section{KOLABORATIF}

dari "kolaborasi", tindakan bekerja bersama, kerja yang dipersatukan, kerja sama. $^{2}$

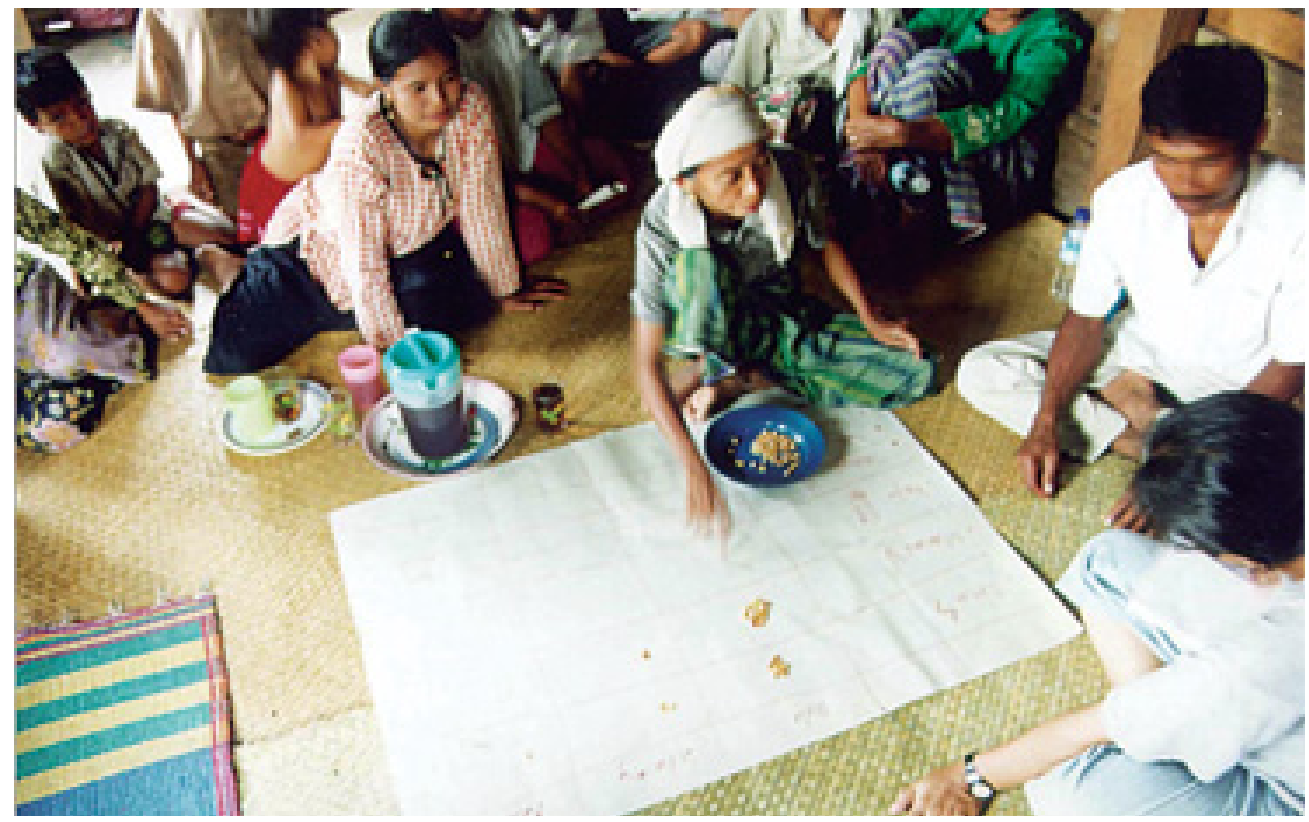

Interaksi dinamis sangat mungkin merangsang terjadinya adaptasi dan kerja sama. 


\section{Pengelolaan Adaptif}

Mereka yang bekerja dalam pengelolaan sumber daya alam dan bidang ekologi sering menghadapi keadaan yang tidak pasti, dinamis dan kompleks karena nilainilai sosial, kebijakan, dan lingkungan biofisik senantiasa berubah dengan cepat dan berlanjut. Walaupun menghadapi ketidakpastian seperti itu, mereka tetap harus mengambil keputusan dan melaksanakan apa yang telah direncanakan. Padahal menjalankan suatu rencana berdasarkan informasi yang tidak pasti bisa menghasilkan keputusan yang tidak efektif.

Salah satu jalan keluar dari dilema ini adalah menerapkan suatu pendekatan pengelolaan yang memungkinkan penyesuaian keputusan secara sistematis dan berlanjut. Proses penyesuaian keputusan itu terjadi ketika terkumpulnya informasi yang baru dan terjadinya proses pembelajaran. Gagasan pengelolaan adaptif ini muncul ketika masyarakat menyadari pentingnya menghadapi ketidakpastian, dengan cara merancang intervensi untuk mendorong pembelajaran.

Pengelolaan adaptif merupakan suatu cara bagi para pemangku kepentingan untuk mengambil langkah secara bertanggung jawab ketika menghadapi ketidakpastian. Pendekatan ini memungkinkan dilakukannya perbaikan sesering dibutuhkan melalui proses yang berulang-ulang seperti digambarkan dalam Gambar 2.

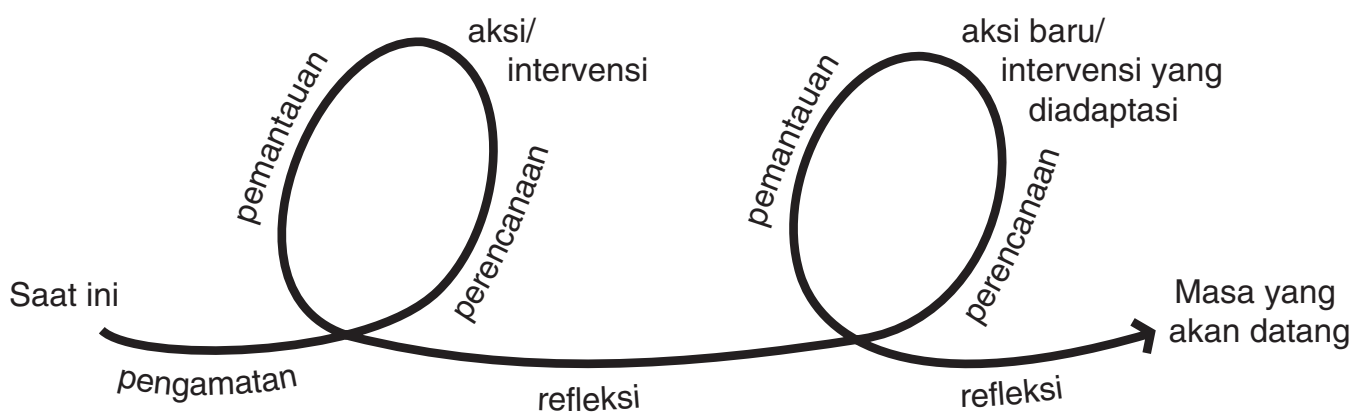

Gambar 2. Proses berulang-ulang pengelolaan adaptif

Proses pengelolaan adaptif dimulai dengan refleksi untuk mengidentifikasi masalah-masalah mendasar, peluang, dan pokok persoalan. Hasil refleksi itu kemudian diangkat sebagai faktor yang penting untuk dipertimbangkan dalam perencanaan, diikuti dengan tindakan nyata untuk mencapai tujuan pengelolaan. Pada saat membuat perencanaan, para pengelola juga harus merancang bagaimana mereka akan memantau apakah rencana tersebut dapat memenuhi tujuan dan apakah rencana itu efektif. Hasil pemantauan digunakan dalam proses evaluasil refleksi untuk: 
- menemukan penyebab tidak efektifnya suatu rencana atau tindakan tertentu dan mengidentifikasi keunggulan dan kelemahan keputusan yang telah diambil sebelumnya

- menjajaki apakah tujuan masih tetap relevan

- mengidentifikasi perubahan yang terjadi-seperti perubahan akibat kebakaran hutan, kebijakan baru, atau perubahan demografi-di dalam keseluruhan sistem sosial dan sumber daya alam yang membutuhkan penyesuaian rencana

- mempertimbangkan langkah selanjutnya, termasuk kemungkinan perlunya penyesuaian rencana dan tujuan semula.

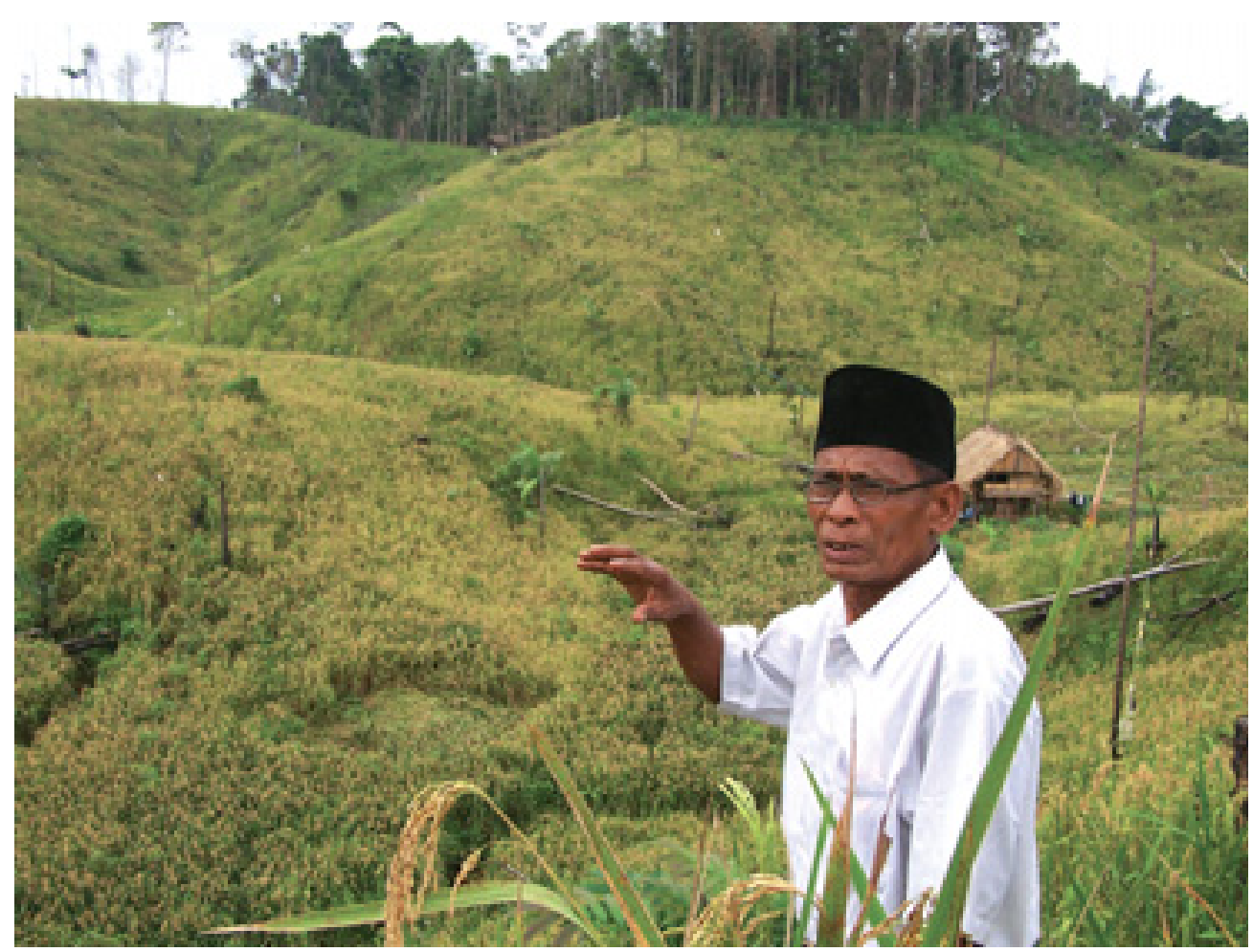

Pengelolaan sumber daya alam lokal mencakup sistem alam dan sistem sosial yang rumit dan dinamis.

Kunci keberhasilan pengelolaan adaptif adalah belajar dari pengalaman yang lalu untuk merencanakan masa depan yang lebih baik. Proses berulang-ulang sebagaimana digambarkan di atas mengharuskan para pengelola untuk terusmenerus menilai efektivitas rencana dan tindakan mereka. Dengan sendirinya mereka akan menyadari perubahan yang terjadi dalam lingkungan mereka karena tindakan-tindakan mereka. Dengan langkah ini, mereka dapat menyesuaikan diri terhadap lingkungan yang terus berubah. 
Namun bisa saja seseorang atau suatu kelompok tertentu (misalnya para pengambil keputusan atau pelaksana proyek kehutanan) melakukan proses berulang-ulang tersebut tanpa melibatkan pihak lain. Hal ini bisa mengakibatkan rendahnya keterlibatan pemangku kepentingan lainnya, yang kemudian dapat membawa kita pada sistem pengambilan keputusan dan perencanaan yang "top-down" dan kurangnya proses pembelajaran antarpihak. Karenanya, agar proses pembelajaran dan adaptasi dapat berjalan dengan baik, menjadi suatu keharusan bahwa semua pemangku kepentingan mengadopsi pendekatan ini secara bersama-sama.

Para praktisi pengelolaan sumber daya alam di berbagai penjuru dunia telah menyadari bahwa kebiasaan umum pengambilan keputusan secara top-down adalah penyebab utama dari banyaknya kegagalan proyek pengelolaan sumber daya alam. Hal ini terutama karena para pengambil keputusan itu kurang memahami kondisi lokal.

Kotak 1. Sistem pengambilan keputusan secara top-down

Pada sistem pengambilan keputusan secara top-down, biasanya pengambil keputusan berada di lokasi dan posisi yang jauh dari dampak keputusan yang mereka buat. Keputusan dibuat oleh mereka yang berada di puncak hirarki (misalnya pemerintah pusat) dan dipaksakan untuk diterapkan oleh mereka yang berada di lapisan bawah hirarki tersebut (misalnya kelompok-kelompok pengguna hutan).

\section{Pengelolaan Kolaboratif}

Seperti juga pendekatan pengelolaan adaptif, pengelolaan kolaboratif bukanlah konsep yang baru. Berbagai bentuk kerja sama dalam pengelolaan sumber daya sudah dikenal di berbagai negara dalam beberapa dasawarsa belakangan ini. Namun, di Indonesia, bentuk pengelolaan sumber daya hutan semacam ini baru dikenal pada akhir tahun 1990-an. Gambaran lebih rinci sejarah pengelolaan secara kolaboratif di Indonesia dapat dilihat dalam Bab 3.

Istilah collaborative management (pengelolaan secara kolaboratif) dalam bahasa Inggris sering digunakan secara bergantian dengan berbagai istilah lainnya seperti co-management (pengelolaan secara kemitraan), participatory management (pengelolaan partisipatif), joint management (pengelolaan bersama), shared management (pengelolaan berbagi), multistakeholder management (pengelolaan multipihak), atau round-table management (pengelolaan meja bundar). Dalam 
bentuk aslinya, pengelolaan secara kolaboratif merupakan proses partisipatif yang melibatkan semua pemangku kepentingan secara aktif dalam berbagai kegiatan pengelolaan, termasuk pengembangan visi bersama, belajar bersama, dan penyesuaian praktek-praktek pengelolaan mereka. Walaupun demikian, pengelolaan secara kolaboratif memiliki beberapa kelemahan yang perlu diperhatikan para pengelola hutan dan pengambil kebijakan (Kotak 2).

Kotak 2. Kelemahan pengelolaan secara kolaboratif yang sering terjadi

- Para pengelola hutan sering menggunakan istilah "kolaborasi" dan "partisipasi" dengan maksud yang sama. Hal ini bisa menjadi masalah jika istilah "kolaborasi" hanya diartikan sebagai ajakan bagi masyarakat dan kelompok-kelompok lokal untuk "berpartisipasi" di tahap pelaksanaan saja, sehingga mereka tidak terlibat dalam menentukan cara menganalisis permasalahan maupun melaksanakan dan memantau rencana yang dibuat.

- Dengan demikian, tujuan, metode, dan rencana pengelolaan hutan dalam kenyataannya masih berada dalam ranah kegiatan "orang luar". Jika "orang luar" itu kurang mengenal konteks lokal dan cenderung melihat permasalahannya dari sudut pandang mereka sendiri saja, rancangan pengelolaan bisa jadi tidak sesuai dengan kebutuhan lokal dan mengakibatkan gagalnya pengelolaan.

- Potensi pengelolaan secara kolaboratif (seperti menciptakan peluang bagi berbagai kelompok untuk belajar bersama dan bernegosiasi) tidak bisa dicapai jika "partisipasi" tidak diartikan sebagai upaya penentuan nasib sendiri oleh kelompok-kelompok lokal.

Kunci keberhasilan pengelolaan kolaboratif adalah:

1) Para pemangku kepentingan kunci tidak hanya berpartisipasi dalam pelaksanaan saja, tetapi dalam semua tahapan pengelolaan: pengamatan, perencanaan, aksi, pemantauan, dan refleksi.

2) Pengembangan minat, keterampilan, dan kemampuan lokal yang dapat membantu para pemangku kepentingan menyesuaikan diri dengan dinamika perubahan yang sangat cepat setelah proyek selesai. Salah satu cara untuk meningkatkan kemampuan para pemangku kepentingan dalam menanggapi perubahan adalah dengan mengikuti pembelajaran yang berkelanjutan dan terstruktur yang dapat membantu dalam mengadaptasi pendekatan pengelolaan mereka. 


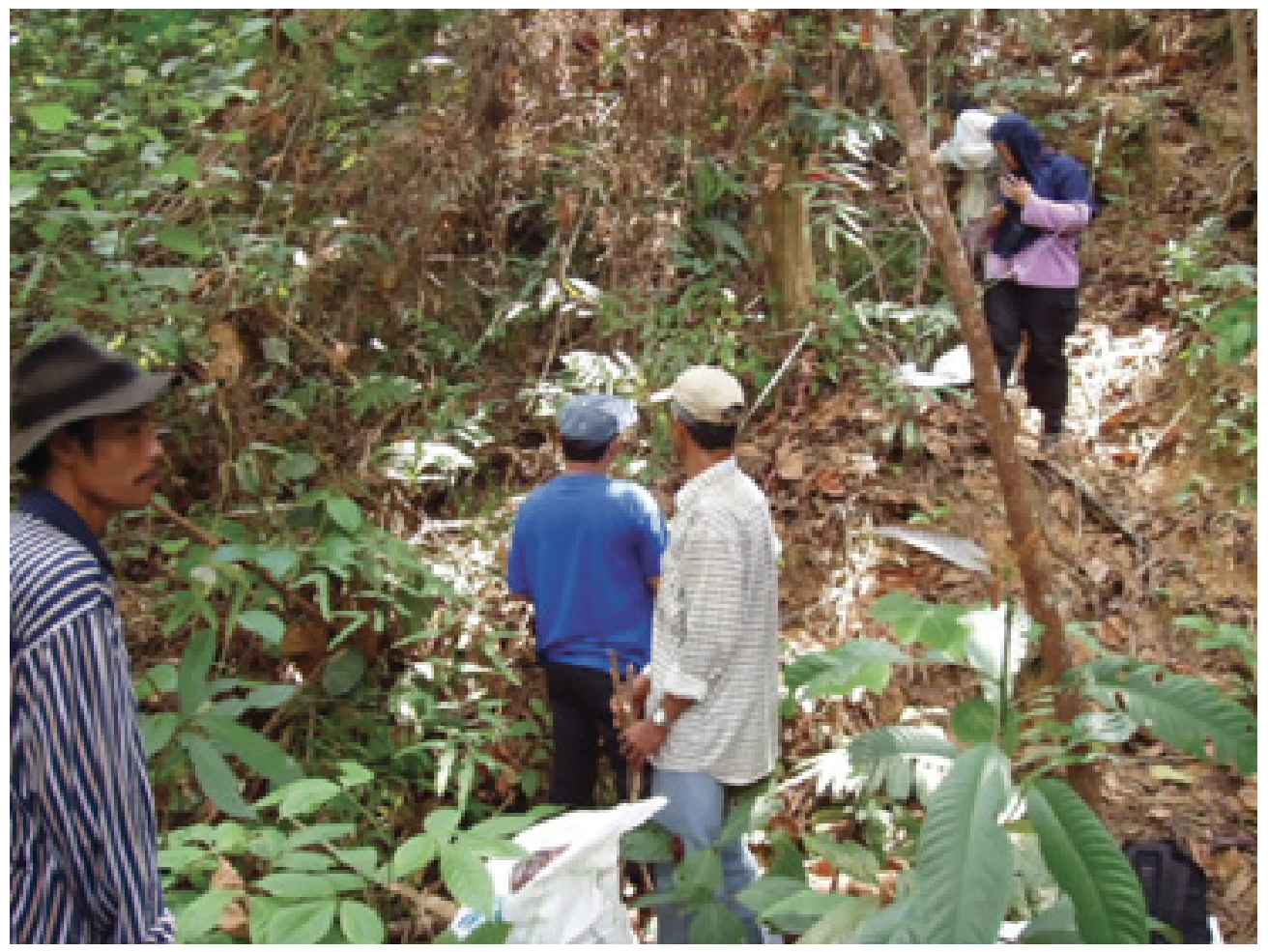

Keterlibatan semua pemangku kepentingan, termasuk masyarakat lokal, dalam seluruh tahapan pengelolaan dapat membantu pengembangan keterampilan, minat, dan kapasitas lokal. Gambar ini menunjukkan bagaimana masyarakat lokal berperan serta dalam analisis vegetasi hutan adat mereka.

\section{ACM: Menggabungkan Pengelolaan Adaptif dan Pengelolaan Kolaboratif}

Adaptive Collaborative Management (ACM) menggabungkan prinsip-prinsip pengelolaan adaptif dan pengelolaan kolaboratif untuk memanfaatkan keunggulan-keunggulan dan mengatasi kelemahan-kelemahan masing-masing pendekatan itu (Gambar 3).

Ciri-ciri utama pengelolaan adaptif
Ciri-ciri utama pengelolaan

kolaboratif/bersama

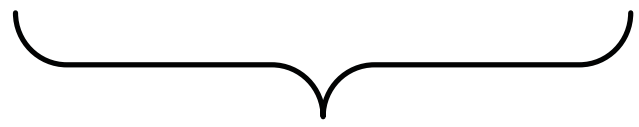

Adaptive Collaborative Management

(Pengelolaan Bersama Secara Adaptif)

Gambar 3. Menggabungkan ciri-ciri dua konsep untuk membentuk ACM 
Sebagaimana telah disebutkan di bagian awal bab ini, ACM merupakan suatu pendekatan yang mendorong para pemangku kepentingan untuk bekerja sama dalam merencanakan, mengamati, dan menarik pelajaran dari perencanaan yang telah dibuat sebelumnya. Maka penting untuk dilihat bahwa ciri khas proses ACM adalah usaha-usaha sadar dari para pemangku kepentingan untuk secara berkelanjutan menjalin komunikasi, kolaborasi, dan negosiasi serta mencari peluang untuk belajar secara bersama mengenai dampak dari tindakan-tindakan mereka.

Kotak 3. Definisi kami tentang kemampuan beradaptasi dan kemampuan berkolaborasi: ${ }^{3}$

KEMAMPUAN BERADAPTASI: kemampuan sesuatu, seseorang, masyarakat, atau sebuah kelompok di dalam masyarakat untuk menanggapi secara aktif dan positif faktor-faktor luar (eksternal) atau faktor-faktor dalam (internal).

KEMAMPUAN BERKOLABORASI: partisipasi secara sukarela para pemangku kepentingan dalam proses pengelolaan, khususnya dalam proses pembelajaran.

Penting untuk dicatat bahwa kemampuan berkolaborasi tidak mengacu pada tatanan tertentu pengelolaan hutan. Kemampuan berkolaborasi tidak mensyaratkan siapa saja yang bisa dilibatkan dalam suatu upaya kolaborasi, ataupun tentang pembagian peran dan tanggung jawab di antara mereka. Apabila aspek etika dipertimbangkan dan agar tujuan suatu upaya bersama benar-benar bermakna bagi mereka yang terlibat, maka kolaborasi akan sangat ditentukan oleh partisipasi para pemangku kepentingan yang memainkan peran kunci dalam suatu kawasan hutan, khususnya mereka yang tersingkirkan selama ini.

\section{Unsur-unsur ACM}

Ada tiga proses umum yang tercakup dalam pendekatan ACM (Kotak 4) yang jika kita cermati secara keseluruhan memiliki ciri-ciri sebagai berikut:

- Komunikasi dan arus informasi yang efektif antara anggota kelompok atau antara para pemangku kepentingan

- Partisipasi aktif dan keterwakilan yang memadai dari semua pemangku kepentingan dalam pengambilan keputusan dan dalam setiap proses negosiasi dengan pemangku kepentingan lain

- Adanya mekanisme untuk menangani konflik dan menghadapi ketidakpastian serta perubahan-perubahan yang cepat dan mendadak 
- Pembelajaran dan eksperimen yang dilakukan secara sengaja

- Adanya kemauan (sikap) dan kapasitas (keterampilan dan sumber daya) organisasi untuk belajar dan menanggapi hasil pembelajaran

- Sikap saling menghormati dan saling mempercayai serta keterbukaan

- Saling berbagi pengetahuan dan keterampilan

- Perencanaan, pengambilan keputusan, tindakan, dan pemantauan yang dilakukan bersama; kesemuanya dengan memperhatikan secara cermat hubungan-hubungan di dalam sistem sosial dan sistem alam, maupun kaitankaitan di antara sistem-sistem itu.

Kotak 4. Tiga proses umum yang terdapat dalam pendekatan ACM

ACM terdiri dari siklus-siklus adaptif yang dilakukan secara kolaboratif dengan melibatkan semua pemangku kepentingan kunci. Secara sederhana ACM dapat digambarkan sebagai proses yang mencakup:

1. Interaksi antara para pemangku kepentingan

2. Komunikasi dan pembelajaran di antara para pemangku kepentingan

3. Tindakan bersama, yang menghasilkan perubahan atau penyesuaian pengelolaan.

\section{Bagaimana kita memfasilitasi proses ACM?}

Sebelum memfasilitasi sebuah proses ACM, kita mulai dengan beberapa pertanyaan berikut ini:

- Siapa yang harus dilibatkan dalam proses ini?

- Siapa saja para pemangku kepentingan pengelolaan hutan yang berada di kawasan ini?

- Apakah di masa lalu telah terjadi perubahan-perubahan yang signifikan terhadap kondisi hutan dan, jika "ya", apa saja perubahan itu dan mengapa perubahan itu terjadi?

- Apa saja permasalahan utama yang telah menyebabkan berkurangnya luas hutan?

Memperoleh jawaban-jawaban yang tepat atas pertanyaan-pertanyaan tersebut dan pemahaman yang mendalam tentang konteks lokal, merupakan hal yang penting dan mendasar bagi para fasilitator ACM. Itulah sebabnya mengapa para fasilitator sedini mungkin harus:

- Membangun kepercayaan dan kemitraan. Kemitraan yang baik antara fasilitator dan para pemangku kepentingan, maupun antara pemangku-pemangku kepentingan. Membangun kepercayaan merupakan langkah yang utama 
bagi fasilitator, karena tanpa kepercayaan kepada fasilitator bisa jadi para pemangku kepentingan tidak akan mau berbagi pandangan secara bebas sehingga informasi dan masalah-masalah penting tetap tersembunyi.

- Memahami konteks lokal. Hal ini mencakup identifikasi para pemangku kepentingan di lokasi yang bersangkutan, termasuk peran, wewenang, dan tanggung jawab masing-masing pemangku kepentingan, serta sejarah lokal yang terkait dengan pengelolaan hutan.

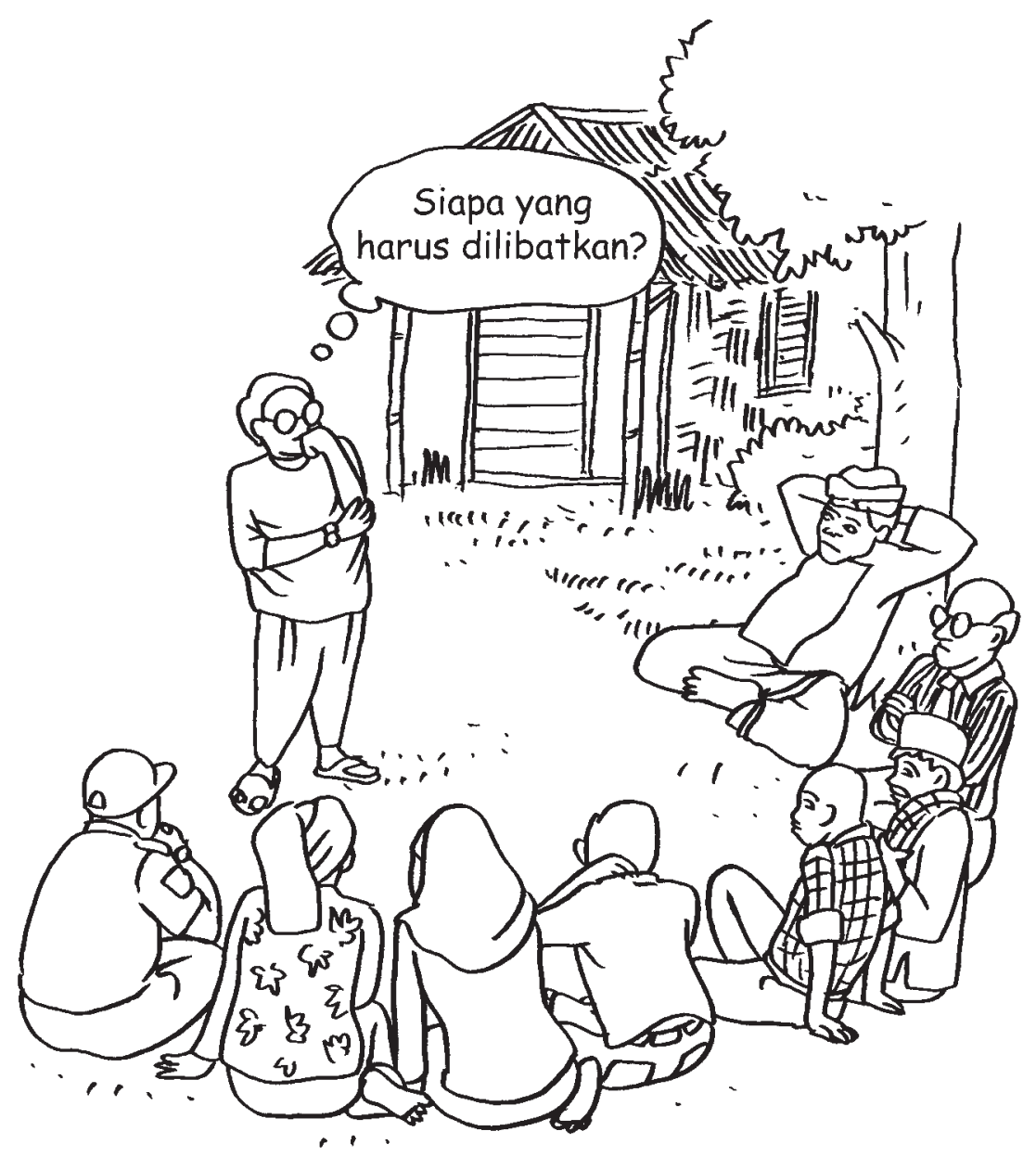

Kotak 5. Analisis pemangku kepentingan

Analisis ini bertujuan untuk mengidentifikasi para pemangku kepentingan dalam suatu sistem dan untuk menjajaki kepentingan-kepentingan mereka masingmasing dalam sistem tersebut. Beberapa acuan dan metode untuk menganalisis pemangku kepentingan dapat dilihat pada Lampiran 1 dan Lampiran 2. 
Setelah memperoleh pemahaman yang memadai tentang konteks lokal dan kepercayaan di antara pihak yang terlibat sudah cukup terbangun, fasilitator dapat menyelenggarakan pertemuan/lokakarya untuk mengidentifikasi masalahmasalah utama yang dihadapi para pemangku kepentingan lokal dalam pengelolaan hutan.

Pada tahap itu, pertemuan/lokakarya diselenggarakan juga untuk bersama-sama merencanakan bagaimana menghadapi pokok-pokok permasalahan tersebut, diikuti dengan pelaksanaan, pemantauan dan evaluasi/refleksi, serta penyesuaian untuk rencana baru. Pemangku-pemangku kepentingan kunci yang peran dan kepentingannya relevan dengan pokok-pokok permasalahan tersebut harus dilibatkan dalam pertemuan ini.

Seluruh langkah dalam proses ACM digambarkan pada Gambar 4. Dalam gambar ini kita dapat melihat adanya proses iteratif yang menjadi ciri khas pengelolaan adaptif dan memungkinkan perbaikan pengelolaan sesering dibutuhkan (lihat hlm. 21). Aspek kolaborasi dalam proses ini adalah bahwa semua pemangku kepentingan dilibatkan secara aktif sepanjang proses iteratif itu.

\section{ACM dan kriteria dan indikator}

Pada tahap awal proses ACM, masyarakat dan/atau para pemangku kepentingan lainnya mungkin akan menyampaikan harapan-harapannya, permasalahannya, rasa frustasinya, dll. Bisa jadi hal ini mempersulit penentuan prioritas pokok permasalahan. Karena itulah, penting untuk selalu mengingat tujuan utama dari ACM.

Dalam rangka penelitian ACM yang diselenggarakan CIFOR, tujuan ACM adalah mengembangkan pengelolaan hutan berkelanjutan (PHB atau sustainable forest management (SFM)). Untuk "membingkai" kegiatan agar dapat mencapai PHB, pertama-tama kita perlu mengidentifikasi permasalahan kunci dalam PHB, kemudian menentukan kegiatan atau keluaran (outcomes) yang dapat membantu tercapainya PHB. Dengan cara ini, akan terbentuk kerangka kerja yang terdiri dari tujuan, kegiatan, dan hasil di bidang sosial, ekonomi, kebijakan, ekologi, dan produksi. Ini menjadi dasar untuk menentukan kriteria dan indikator (K\&I) PHB.

K\&I adalah salah satu alat bantu yang dapat digunakan untuk mengidentifikasi permasalahan kunci di suatu tempat/unit manajemen hutan, peluang, dan pokok persoalan lain serta mengembangkan sistem pemantauan. Lebih penting lagi, K\&I dapat mengidentifikasi kendala-kendala dalam mencapai keadaan yang diinginkan. Hal ini termasuk upaya untuk memahami hubungan sebab 

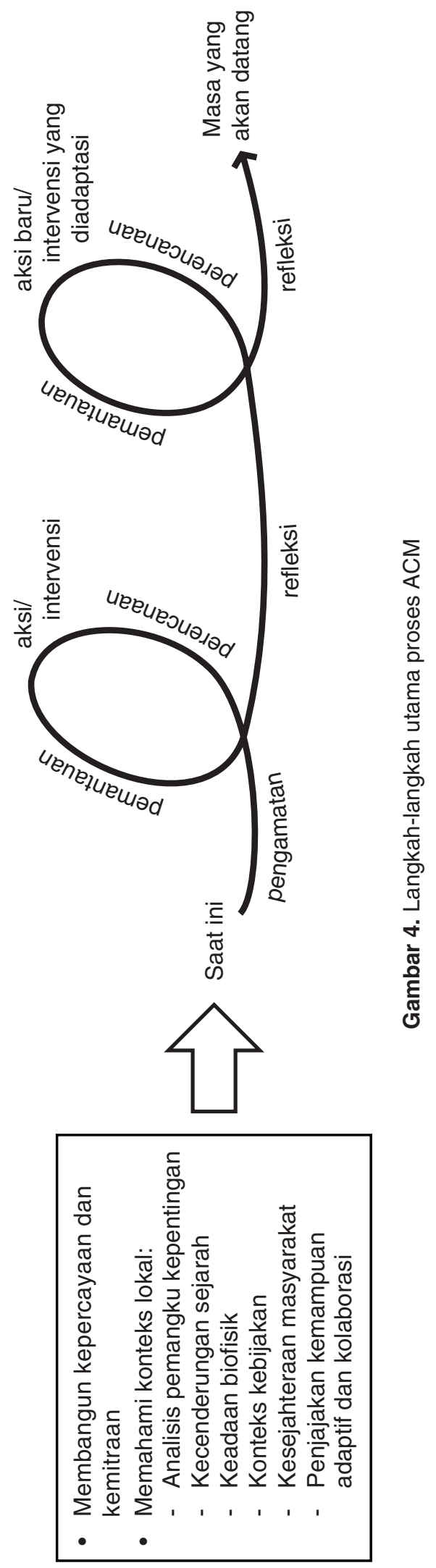
akibat antara masalah-masalah yang berbeda, misalnya dengan menggunakan metode "pohon masalah". Dalam Kotak 6 disajikan beberapa acuan untuk mengembangkan K\&I.

Kotak 6. Beberapa acuan dalam mengembangkan K\&I

Alat-alat sebagai berikut dapat membantu kita dalam mengembangkan dan menilai K\&I pengelolaan hutan yang berkelanjutan dan berkeadilan:

Perangkat K\&l (C\&/ Toolbox)

Adalah serangkaian panduan dan perangkat lunak yang dikembangkan oleh CIFOR dalam proyek tentang Pengujian Kriteria dan Indikator Pengelolaan Hutan secara Berkelanjutan pada tahun 1999 (lihat Lampiran 2 untuk bahan bacaan lebih lanjut).

Pedoman Pendahuluan: Kriteria dan Indikator Kelestarian Hutan yang Dikelola oleh Masyarakat.

Ritchie, B., C. McDougall, M. Haggith \& N. Burford de Oliveira. 2001. CIFOR, Bogor, Indonesia.

\section{ACM dan pembelajaran sosial}

Sebagaimana telah disebutkan sebelumnya, kunci keberhasilan dalam mengembangkan suatu proses adaptif yang mengarah pada peningkatan kemampuan pengelolaan, adalah pembelajaran sosial di antara para pemangku kepentingan. Pembelajaran sosial dalam hal ini adalah pembelajaran yang terjadi di dalam sekelompok orang, bukannya pembelajaran yang dialami oleh masingmasing orang secara terpisah. ${ }^{4}$

Indikator yang menunjukkan apakah pembelajaran sosial telah terjadi adalah antara lain: perubahan pemahaman, persepsi, tingkah laku, tindakan kelompok, dll. Untuk lokasi tertentu akan diperlukan indikator-indikator yang sesuai dengan keadaan di lokasi tersebut, misalnya cara-cara kelompok mengkaji atau menanggapi informasi baru berkaitan dengan lokasi itu.

Untuk membangun minat para pemangku kepentingan agar belajar dan memastikan bahwa pembelajaran sosial akan terjadi, ada tiga elemen yang diperlukan:

- Pokok persoalan atau fokus yang jelas

- Gagasan atau informasi baru

- Platform komunikasi (forum ataupun basis untuk berkomunikasi). 


\section{ACM dan fasilitasi}

Fasilitasi memainkan peran penting dalam mendorong pembelajaran sosial melalui interaksi yang konstruktif. ${ }^{5}$ Pada situasi konflik yang tinggi atau saingan yang kuat di antara para pemangku kepentingan mengenai tanah hutan dan sumber daya hutan, fasilitasi sangat menentukan sejauh mana mereka dapat dipertemukan dan hubungan konstruktif di antara mereka dapat dibangun melalui dialog terbuka. Fasilitasi dapat didefinisikan sebagaimana terlihat di Kotak 7.

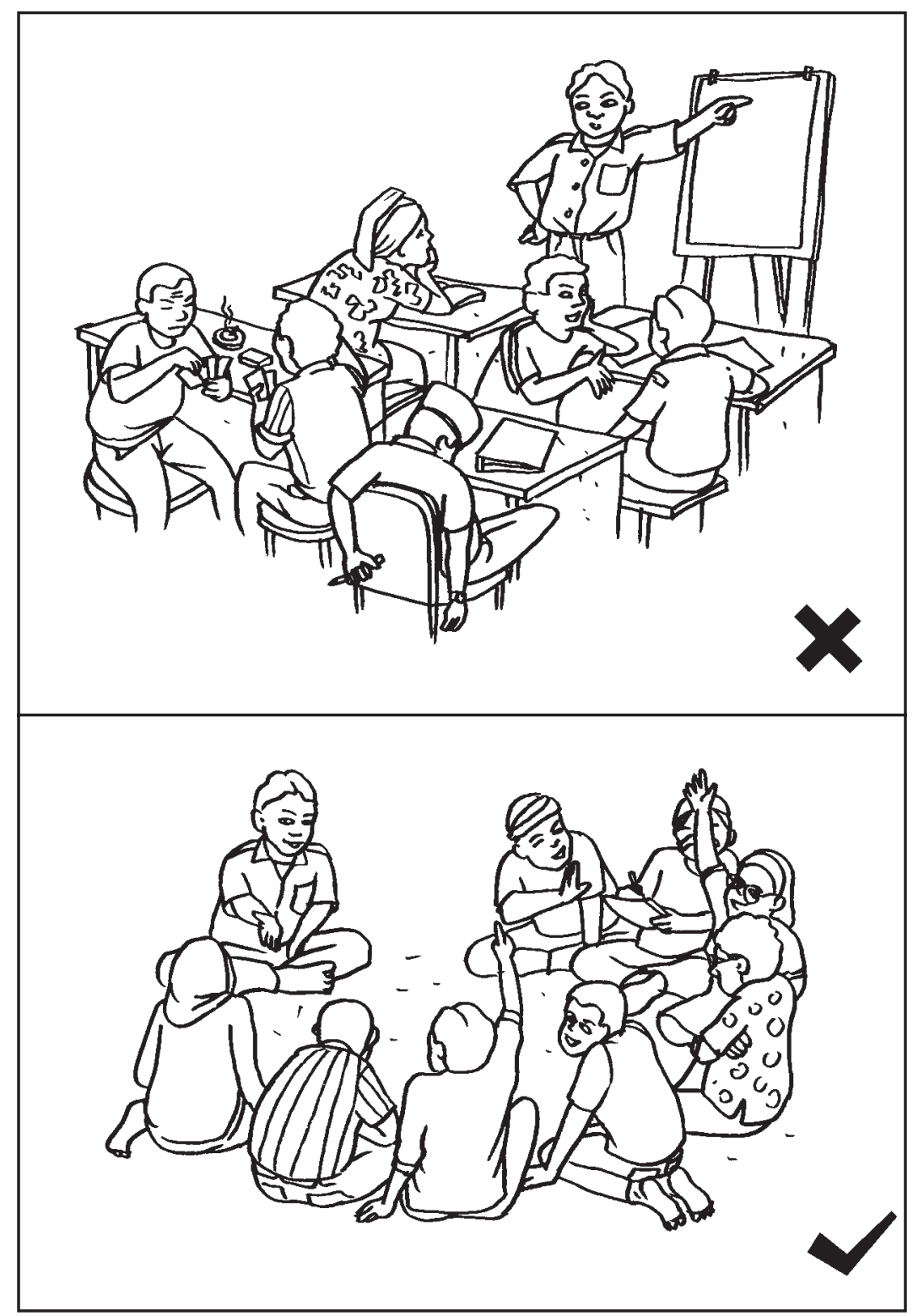


Kotak 7. Definisi fasilitasi ${ }^{6}$

Kita dapat mendefinisikan fasilitasi sebagai proses sadar dalam mendampingi suatu kelompok agar secara berhasil mencapai tujuan-tujuan kelompok itu, dengan tetap berfungsi sebagai kelompok. Patut diperhatikan bahwa fasilitasi bukan berarti memimpin pertemuan kelompok, memberi pengarahan, atau berceramah.

Dalam pengelolaan hutan, pihak-pihak yang dominan tidak seharusnya menjadi satu-satunya pengambil keputusan. Karenanya, fasilitator perlu mengembangkan strategi, mekanisme, dan kondisi yang dapat membantu menyeimbangkan kekuatan antara para pemangku kepentingan dengan tujuan untuk:

- Mendorong dinamika kelompok yang baik dan komunikasi yang konstruktif

- Memfasilitasi adanya keterwakilan atau kesempatan yang setara bagi semua pihak untuk berbicara dan untuk didengar

- Memastikan adanya akuntabilitas (pertanggungjawaban) para wakil pemangku-pemangku kepentingan

- Memastikan bahwa semua pikiran atau gagasan para pemangku kepentingan dihargai dan dipertimbangkan dalam proses pengambilan keputusan.

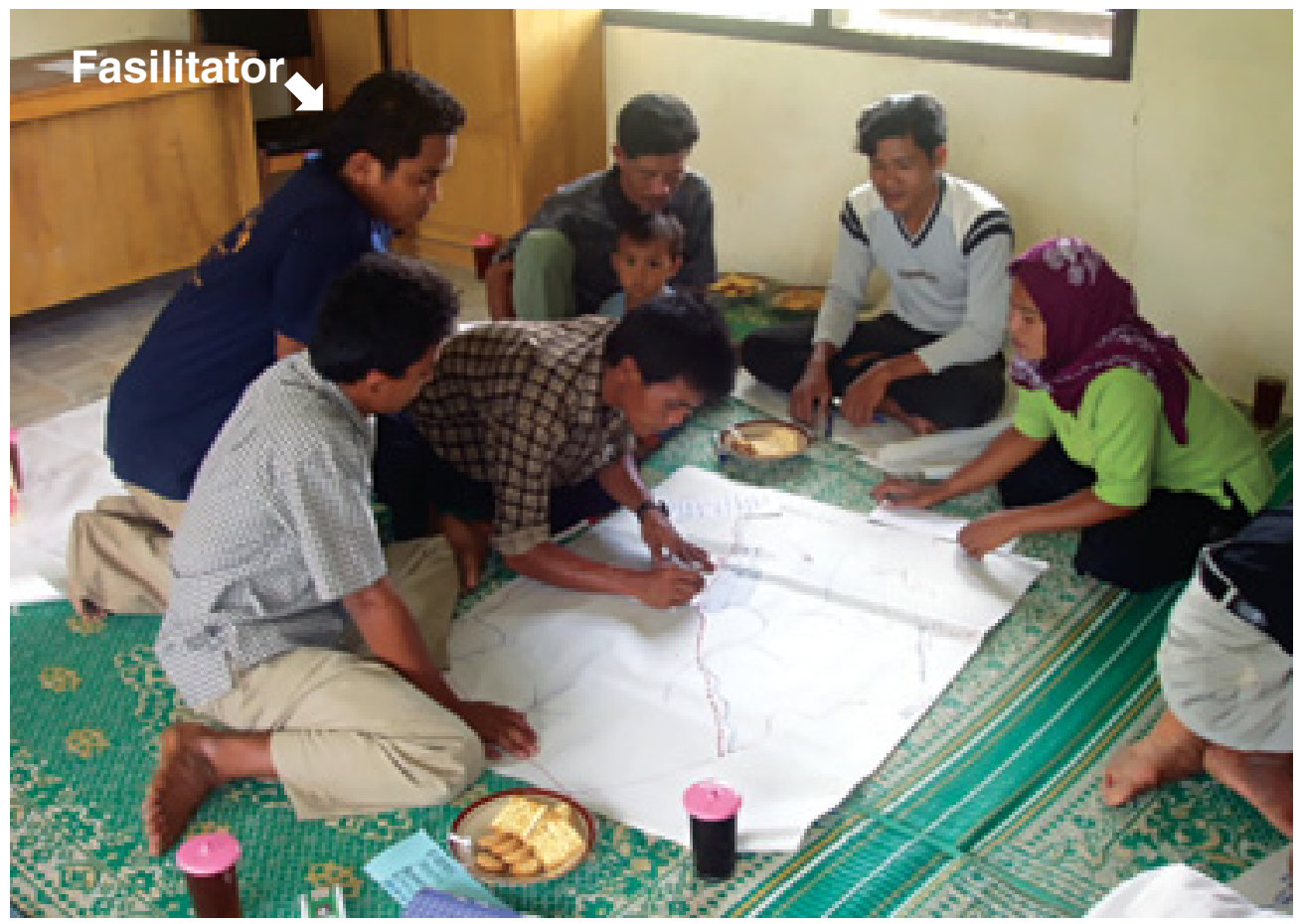

Seorang fasilitator memastikan agar proses-proses dalam kelompok cukup dinamis dan komunikasi di antara peserta konstruktif. Idealnya, hal ini dapat mendorong pembelajaran di antara peserta dan setiap gagasan peserta akan dipertimbangkan dalam pengambilan keputusan. 
Namun, keterwakilan yang baik dan berimbang serta adanya peluang yang merata bagi semua pemangku kepentingan tidak akan terjadi begitu saja. Mengembangkan pembelajaran sosial melalui interaksi yang konstruktif antara para pemangku kepentingan perlu didorong dengan membangun komunikasi yang terbuka dan responsif, maupun dengan mengatasi kendala-kendala yang terdapat di dalam komunikasi itu sendiri. ${ }^{7}$ Sebagai contoh, perbedaan sosial dan pendidikan kadang menjadi hambatan psikologis. Dalam situasi semacam itu kelompok marjinal biasanya merasa inferior dan kurang percaya diri untuk berkomunikasi dengan pejabat pemerintah. Dalam hal ini diperlukan proses peningkatan kapasitas dan rasa percaya diri kelompok yang lebih lemah dalam hal:

- mengelola informasi baru

- negosiasi

- kemampuan organisasi dan lembaga ${ }^{8}$

- pemecahan masalah.

Gambar 5 secara sederhana menggambarkan berbagai peran yang harus dimainkan fasilitator dalam mengembangkan pembelajaran sosial. Penting untuk diperhatikan bahwa pada kenyataannya peran-peran ini bisa saja terjadi tidak secara berurutan atau sesederhana seperti terlihat pada diagram ini.

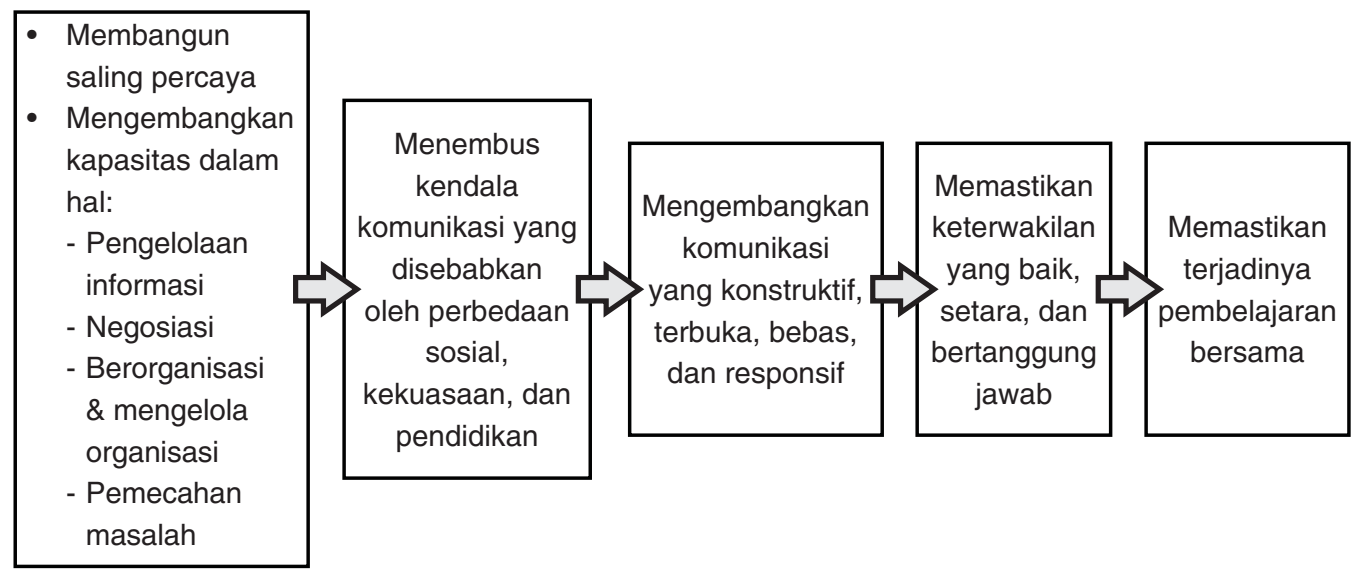

Gambar 5. Berbagai peran fasilitasi dalam mengembangkan pembelajaran sosial

Agar pengelolaan hutan secara kolaboratif dapat tercapai, baik fasilitator maupun para pemangku kepentingan perlu meningkatkan kemampuan mereka dalam hal-hal berikut ini:

- penanganan konflik dan pembuatan keputusan politis

- inovasi dan pemecahan masalah

- pengembangan komunikasi dan hubungan baik

- peningkatan kemampuan masyarakat untuk berorganisasi. 


\section{Apakah nilai tambah yang diharapkan dari penerapan ACM di Indonesia?}

Indonesia telah mengenal berbagai bentuk pendekatan partisipatif dalam pengelolaan hutan (lihat juga Bab 3). Pertanyaan yang muncul kemudian adalah, apakah nilai tambah yang dapat ditawarkan ACM terhadap pengelolaan hutan di negara ini? Harapan tim kami, pendekatan ACM dan hasil penelitian kami akan bermanfaat untuk hal-hal berikut:

- Pendekatan ACM dapat memfasilitasi berbagai pemangku kepentingan dalam mengorganisasi dirinya guna bertindak dan memantau perkembangan maupun akibat tindakannya

- Pendekatan ACM dapat menciptakan kondisi yang memungkinkan terjadinya pembelajaran di antara para pemangku kepentingan yang dilakukan secara sadar

- Pendekatan ACM membantu dalam membuat proses pembelajaran lebih terstruktur

- Pendekatan ACM meningkatkan kapasitas para pemangku kepentingan untuk beradaptasi

- Pendekatan ACM memungkinkan proses fasilitasi dan proses penelitian terjadi secara bersamaan.

\section{ACM dalam praktek}

Bab ini mencoba memaparkan teori-teori yang menjadi latar belakang pendekatan ACM, sementara prakteknya diuraikan dalam bab-bab berikut ini. Bab-bab tersebut menggambarkan bagaimana kami menerapkan ACM di dua lokasi di Indonesia, termasuk proses dan keluarannya. Ketika pemahaman kami tentang konteks lokal dan tentang pendekatan ACM itu sendiri berkembang, kami membuat penyesuaian-penyesuaian penerapan konsep ACM dengan kondisi lokal dan dinamika para pemangku kepentingan. 


\section{Bagian Dua}

\section{Konteks}

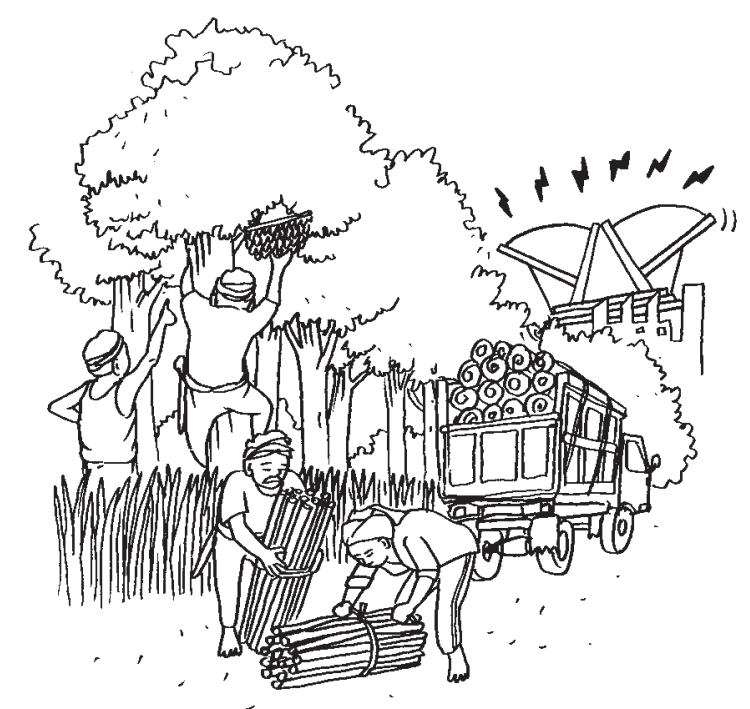

Kemelut sosial yang terjadi di Indonesia pada pergantian abad ke-20 juga mempengaruhi keadaan hutan di Indonesia. Sebuah perkembangan yang positif adalah munculnya berbagai bentuk pengelolaan hutan kolaboratif.

Bagian Dua ini diawali dengan melihat apa yang berada di balik perkembangan tersebut karena hal itu merupakan konteks luas penelitian kami (Bab 3). Tantangan-tantangan yang dihadapi pengelolaan hutan kolaboratif itu juga dibahas dalam bab ini.

Bagian Dua ini kemudian mengkaji konteks lokal penelitian kami. Bab 4 menggambarkan lokasi-lokasi penelitian, masyarakat yang tinggal di sana, pihak-pihak luar yang tertarik pada sumber daya hutan, dan persepsi-persepsi berbagai kelompok tersebut tentang pemanfaatan dan pengelolaan hutan. Keadaan tidak pasti yang dihadapi kelompokkelompok itu dan disebabkan oleh perubahan sumber penghidupan, hubungan sosial, dan kebijakan juga merupakan salah satu aspek dari konteks lokal penelitian kami. Maka dari itu, Bab 4 juga membahas kondisi tidak pasti tersebut. Selanjutnya, bab ini memaparkan penilaian tim kami tentang kemampuan kolaboratif dan kemampuan adaptif kelompok-kelompok lokal di lokasi penelitian. 

3

PENGELOLAAN HUTAN SECARA KOLABORATIF DI INDONESIA

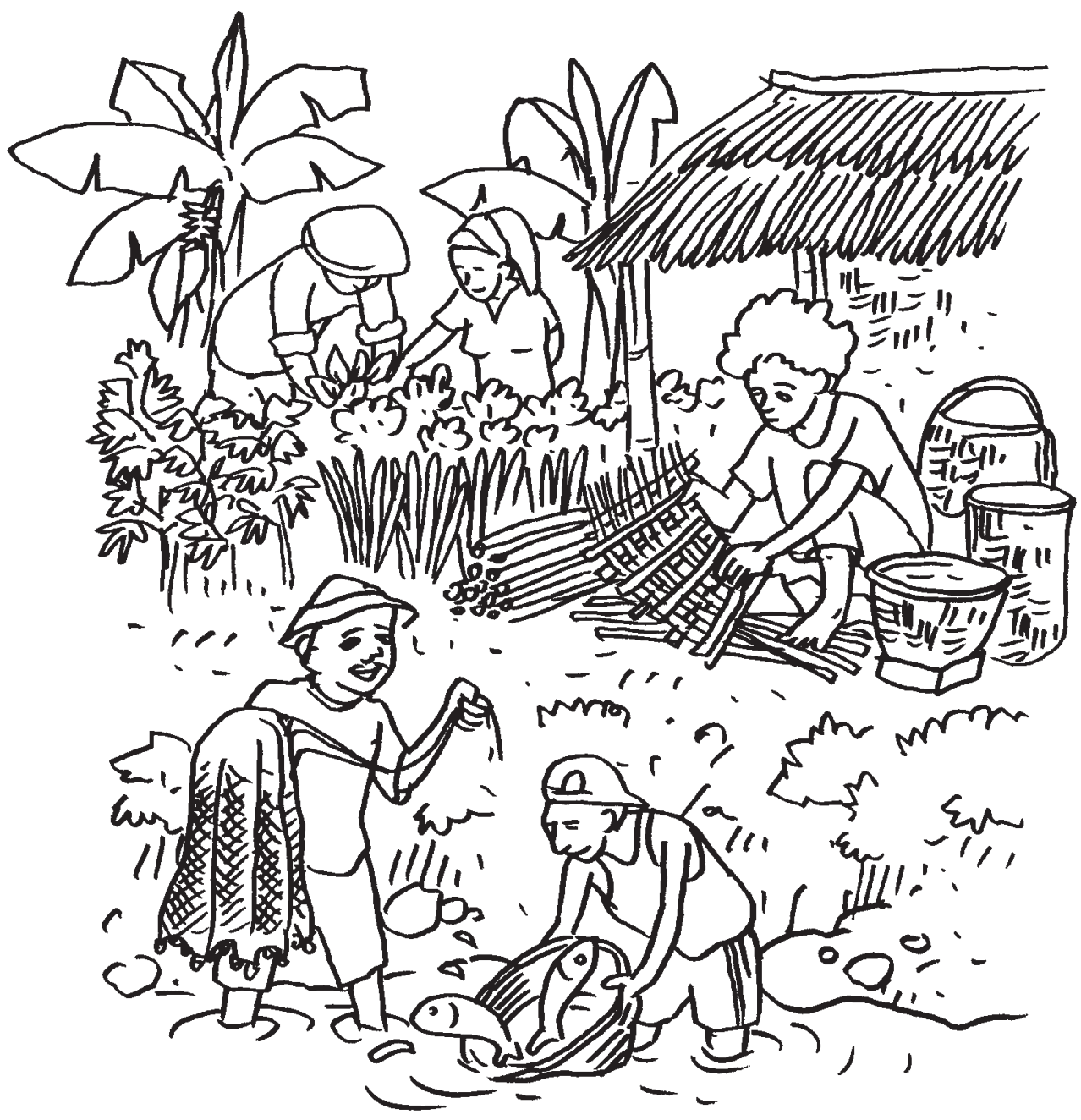


Kemerdekaanmu dan kemerdekaanku tidak terpisahkan.

(Your freedom and mine cannot be separated.)

Nelson Mandela, pemimpin tingkat dunia 
Sebagaimana telah kami sampaikan, kami memulai penelitian ACM di tengahtengah krisis ekonomi dan sosial-politik di Indonesia. Didorong oleh tuntutan yang meluas akan pengelolaan hutan yang lebih berkelanjutan dan lebih berkeadilan, pendekatan kolaboratif dalam pengelolaan hutan muncul hanya beberapa saat sebelum kami memulai penelitian ACM. Karena keadaan ini menjadi konteks utama penelitian kami, bab ini mengulas hal tersebut.

\section{Sejarahnya}

Walaupun pengelolaan hutan secara kolaboratif di Indonesia relatif baru, perkembangannya berpangkal pada awal tahun 1970-an, ketika pemerintah mulai bereksperimen dengan partisipasi masyarakat dalam pengelolaan hutan. Pemerintah pada saat itu dihadapkan dengan konflik-konflik sosial yang kian meningkat di antara masyarakat lokal dan proyek-proyek kehutanan, serta tekanan publik dan tuntutan internasional untuk meningkatkan partisipasi masyarakat.

Dalam dua dasawarsa selanjutnya, berbagai prakarsa pengelolaan hutan partisipatif dikembangkan dan diujicobakan. Selain pemerintah, aktivis LSM, peneliti, dan penyandang dana juga memainkan peranan penting dalam prakarsa ini. Seiring dengan berjalannya waktu, prakarsa-prakarsa itu berkembang dari pendekatan yang sekedar "mengajak" kelompok lokal untuk berpartisipasi dalam kegiatan lapangan, menjadi pendekatan yang memberi mereka kewenangan dalam pengambilan keputusan (bandingkan juga Kotak 2 dalam Bab 2). Dalam evolusi ini ada tiga tahapan umum yang dapat dibedakan dengan jelas, yakni:

1) peningkatan akses para pemangku kepentingan lokal terhadap sumber daya hutan

2) pengakuan sistem pengelolaan hutan masyarakat lokal

3) peningkatan kewenangan masyarakat lokal dalam pengambilan keputusan tentang hutan.

\section{Peningkatan akses para pemangku kepentingan lokal terhadap sumber daya hutan}

Di antara kebijakan dan program kehutanan partisipatif pada tahap ini, yang terutama perlu dicatat adalah perhutanan sosial (social forestry). ${ }^{9}$ Secara umum, kebijakan dan program perhutanan sosial pemerintah diarahkan pada peningkatan kondisi sosial-ekonomi pemangku-pemangku kepentingan lokal. Kebijakan ini pertama kali diterapkan pada awal tahun 1970-an di perkebunan kayu jati di pulau Jawa yang dikelola Perum Perhutani. Program ini mengijinkan masyarakat lokal untuk menanam tanaman tahunan/tanaman semusim nonkayu di antara pohon-pohon jati dengan syarat mereka menyediakan tenaga kerja 


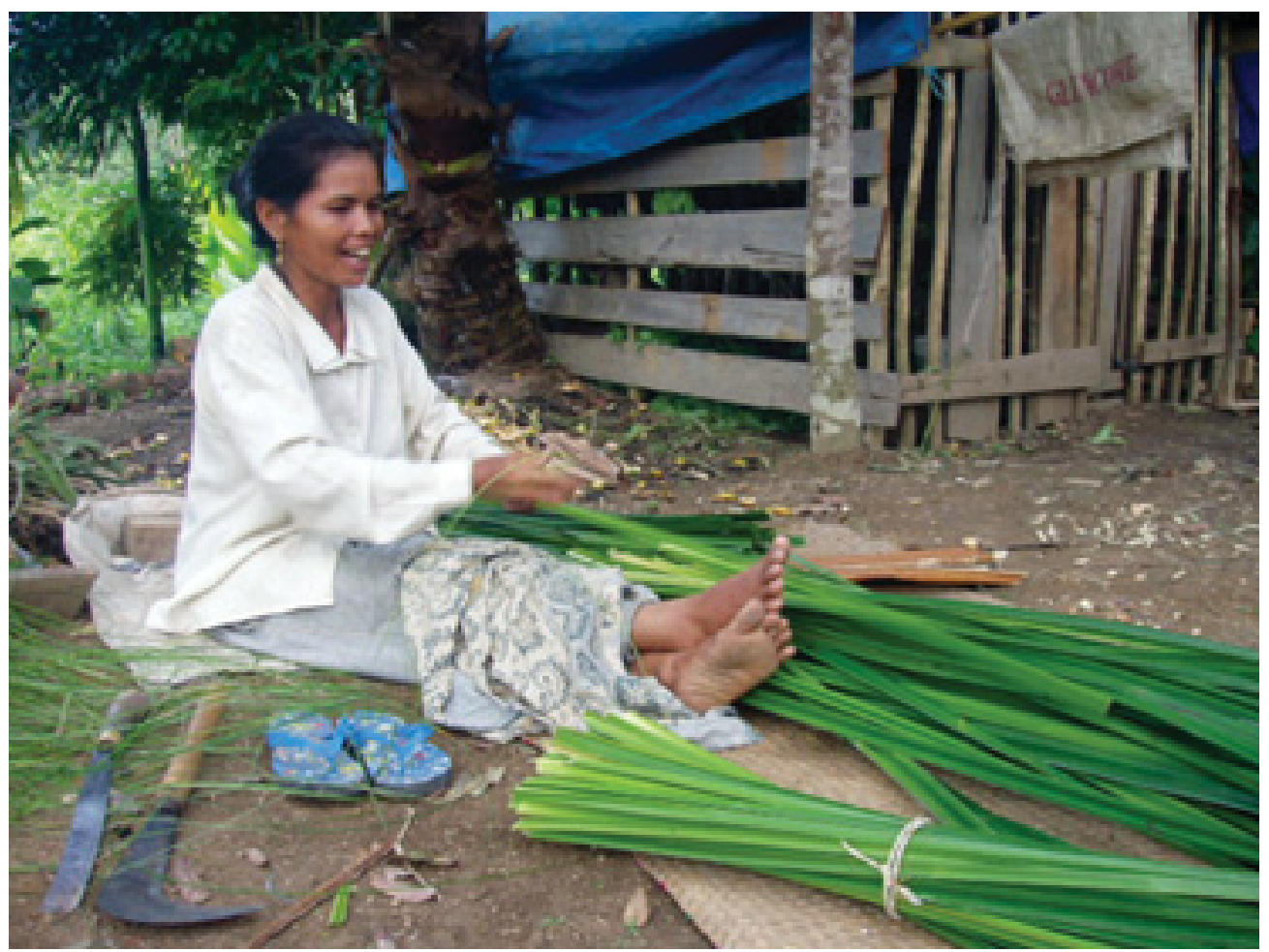

Tujuan umum kebanyakan program perhutanan sosial adalah perbaikan kondisi sosial-ekonomi masyarakat lokal dengan cara meningkatkan akses mereka terhadap sumber daya hutan.

untuk kegiatan penanaman jatinya. Pada awalnya, para pemangku kepentingan lokal tidak diperkenankan memanen kayu, tetapi belum lama ini mereka diperbolehkan memanfaatkan kayu jati yang mereka tanam sendiri.

Pada tahun 1980-an, kebijakan perhutanan sosial yang diawali pada awal tahun 1970-an itu dimodifikasi dan mengambil bentuk program pengembangan masyarakat (seperti Pembinaan Masyarakat Desa Hutan atau PMDH) dan program hutan komunitas (seperti Hutan Kemasyarakatan atau HKm). PMDH tidak memungkinkan partisipasi masyarakat yang luas tetapi mengharuskan para pemegang konsesi hutan untuk memberikan kompensasi finansial kepada masyarakat yang berada dalam wilayah konsesi mereka. HKm memperbolehkan kelompok-kelompok dan masyarakat lokal untuk mengelola wilayah hutan yang sudah terdegradasi dan menciptakan peluang ekonomi untuk mereka. Hal ini memberi mereka hak pemanfaatan hutan, tetapi pemerintah tetap mempunyai wewenang untuk memberikan dan mencabut kembali hak tersebut sesuai dengan pertimbangan-pertimbangan dalam menjalankan kewenangannya.

Dalam tahap pertama ini peran pemerintah sangat penting karena mengadopsi partisipasi masyarakat dalam arus-utama (mainstream) program kehutanan dan mengalokasikan sumber daya untuk pengembangannya. Namun demikian, peran 
LSM lokal, peneliti, aktivis, maupun donor asing tidak kalah pentingnya karena memberi bantuan teknis, evaluasi kritis, dan dana.

Pada tahun 1999, dalam semangat desentralisasi, dikeluarkanlah kebijakan pemerintah yang mengijinkan pembagian keuntungan dari pemanfaatan hasil kayu antara pengusaha hutan dan masyarakat lokal. Meskipun begitu, para pemangku kepentingan lokal tidak turut menentukan besarnya keuntungan yang dibagi.

\section{Pengakuan sistem pengelolaan hutan lokal}

Tahapan kedua menampilkan pergeseran fokus dari pengelolaan hutan skala besar ke arah pengelolaan hutan berbasis masyarakat (PHBsM).

Dari pertengahan tahun 1980-an hingga awal tahun 1990-an ada berbagai upaya pengkajian lapangan yang diprakarsai untuk mengembangkan pemahaman mengenai keanekaragaman sistem pengelolaan hutan lokal yang tersebar di kepulauan Indonesia. Dengan dukungan pendanaan dari donor asing, staf lapangan dinas kehutanan ditugaskan untuk meneliti sistem-sistem lokal pengelolaan hutan. Kajian awal ini kemudian dijadikan dasar pengetahuan bagi pemerintah untuk mengembangkan kebijakan dan program perhutanan sosial.

Perkembangan yang patut dicatat adalah bahwa pada tahun 1998 pemerintah mengakui kewenangan masyarakat adat Krui (Sumatera Selatan) untuk mengelola suatu wilayah di dalam wilayah hutan negara. Kebijakan ini, yang disebut Kawasan dengan Tujuan Istimewa (KdTI), mengakui hak pengelolaan masyarakat Krui dan juga memberi hak pemanfaatan hutan kepada mereka.

Pada saat ini, berbagai prakarsa pengelolaan hutan berbasis masyarakat telah diterapkan di seluruh Indonesia, sebagian besar didanai oleh donor asing dan dilaksanakan oleh LSM lokal. Prakarsa-prakarsa khas ini diperjuangkan oleh aktivis LSM, peneliti, dan donor agar dapat diadopsi secara luas.

\section{Peningkatan kewenangan dalam pengambilan keputusan tentang hutan/ kemitraan dalam pengelolaan hutan}

Berbagai kebijakan dan program pemerintah yang bertujuan meningkatkan kewenangan para pemangku kepentingan lokal dalam pengambilan keputusan tentang hutan baru muncul akhir-akhir ini. Pada akhir tahun 1990-an Perum Perhutani memprakarsai suatu program uji coba yang didukung donor asing dan difasilitasi di lapangan oleh LSM lokal, disebut Pengelolaan Hutan Bersama Masyarakat (PHBM). 
Uji coba tersebut dirancang dengan tujuan untuk mengembangkan kemitraan yang sesungguhnya antara perusahaan dan masyarakat lokal. Berbeda dengan program-program perhutanan sosial terdahulu, program tersebut melibatkan kelompok-kelompok masyarakat lokal bukan sekedar sebagai pekerja pada penanaman pohon jati seperti terjadi sebelumnya, tetapi sebagai mitra yang juga berperan dalam pengambilan keputusan. Dalam upaya ini, peran LSM lokal sangat penting, terutama sebagai mediator antara Perhutani dan masyarakat lokal.

\section{Tantangan dalam Pengembangan Partisipasi Masyarakat dan Pergeseran ke arah Kolaborasi}

Meskipun ada niat baik pemerintah dalam program-program yang menggunakan pendekatan partisipatif, hasilnya tidak seperti yang diharapkan. Pemanfaatan hutan secara tidak berkelanjutan dan tidak berkeadilan masih saja berlangsung. Ada beberapa tantangan dalam penerapan pendekatan partisipatif yang menyebabkan terbatasnya sukses program-program kehutanan itu.

Banyak upaya partisipatif beranggapan bahwa para pemangku kepentingan lokal merupakan kelompok-kelompok homogen yang memiliki kepentingan bersama dalam mengelola hutan. Namun sering, kenyataan di lapangan tidaklah demikian. Masyarakat lokal dan kelompok-kelompok lokal lainnya sering mempunyai kepentingan-kepentingan terhadap hutan yang saling berbeda, atau bahkan bertentangan. Kendati demikian, banyak pemrakarsa upaya partisipatif tidak peka terhadap perbedaan-perbedaan antara kelompok, tidak mengetahui bagaimana menangani konflik, atau tidak memiliki cara untuk mendorong kerja sama. Jadi, tantangan terbesar dalam upaya-upaya partisipatif adalah ketidakmampuan pelaksana upaya-upaya tersebut dalam menghadapi tuntutan-tuntutan yang beragam atas hutan melalui kolaborasi.

Selanjutnya, masih banyak upaya yang walaupun disebut "partisipatif", sesungguhnya tetap bersifat top-down dan kaku terhadap perubahan dan ketidakpastian pada tingkat pengelolaan hutan. Pendekatan top-down semacam itu pada dasarnya hanya menguntungkan negara atau mereka yang cukup berkuasa untuk memperoleh apa yang mereka inginkan. Karenanya, sementara perubahan dan ketidakpastian pada tingkat pengelolaan hutan menuntut cara pengelolaan yang fleksibel, pengambilan keputusan pengelolaan hutan tetap berada di tangan para profesional pengelolaan hutan resmi dan negara. Dengan kata lain, tantangan kedua dalam upaya-upaya partisipatif adalah kekakuan upaya-upaya tersebut dalam mengakomodasi perubahan dan menghadapi ketidakpastian.

Tantangan-tantangan ini telah mempengaruhi perkembangan pendekatan partisipatif di Indonesia, dan bahkan tetap berpengaruh hingga saat ini. 


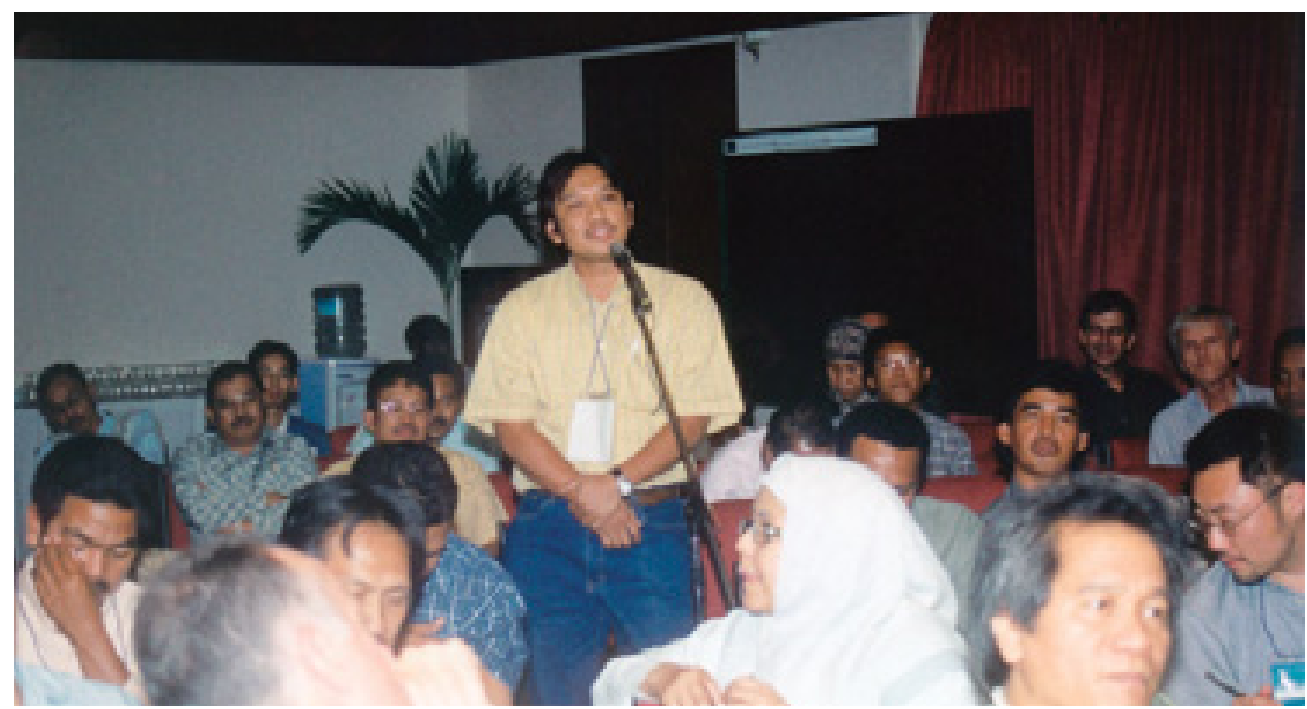

Seminar, pertemuan, dan lokakarya tentang pendekatan partisipatif dalam pengelolaan hutan tidak sedikit jumlahnya. Foto ini memperlihatkan sebuah lokakarya nasional tentang reformasi perhutanan sosial yang diselenggarakan pada bulan September 2002 dan melibatkan wakil masyarakat lokal, pemerintah, LSM, peneliti, dan donor.

Perkembangan terakhir dalam proses ini adalah pergeseran dari pendekatanpendekatan terdahulu yang ternyata tidak mampu menghadapi perbedaanperbedaan tuntutan atas hutan, perubahan dan ketidakpastian, ke arah pengelolaan hutan bersama atau kolaboratif.

Upaya desentralisasi pemerintah dan meningkatnya kekuatan pasar menjadi faktor-faktor penting di belakang pergeseran ini. Faktor-faktor itulah yang mendorong pelibatan berbagai kelompok kepentingan yang lebih luas. Di samping itu, munculnya kelompok-kelompok kepentingan baru dan berubahnya pola-pola hubungan antara kelompok, menjadikan kerja sama suatu kebutuhan pokok.

Gambar 6 menampilkan sebuah rangkaian kesatuan kontinyu (continuum) yang menunjukkan pergeseran dari upaya-upaya pengelolaan hutan yang bersifat partisipatif ke arah kolaborasi.

\begin{tabular}{|ccc|}
\hline Partisipasi & Kolaborasi \\
\cline { 2 - 3 } $\begin{array}{c}\text { Peningkatan akses } \\
\text { sumber daya hutan }\end{array}$ & $\begin{array}{c}\text { Pengakuan sistem lokal } \\
\text { pengelolaan hutan }\end{array}$ & $\begin{array}{c}\text { Peningkatan wewenang } \\
\text { dalam pengambilan } \\
\text { keputusan/kemitraan } \\
\text { dalam pengelolaan hutan }\end{array}$ \\
& & dalam \\
\hline
\end{tabular}

Gambar 6. Rangkaian kesatuan kontinyu (continuum) dari partisipasi ke arah kolaborasi dalam pengelolaan hutan 


\section{Tantangan yang Dihadapi Pengelolaan Hutan Kolaboratif}

Pergeseran dari partisipasi menjadi kolaborasi merupakan perkembangan yang positif dalam pencarian pendekatan pengelolaan hutan yang lebih baik. Namun demikian, belum sepenuhnya jelas apakah pengelolaan hutan kolaboratif dapat mengatasi secara efektif tantangan-tantangan yang gagal dihadapi oleh pendekatan-pendekatan sebelumnya.

Pengelolaan hutan secara kolaboratif di negara-negara Asia lainnya (seperti Joint Forest Management di India, Community Forestry di Nepal, atau CommunityBased Forest Management di Filipina) telah mengalami tantangan-tantangan serupa. Sekalipun merupakan program-program yang relatif mapan, sering dalam

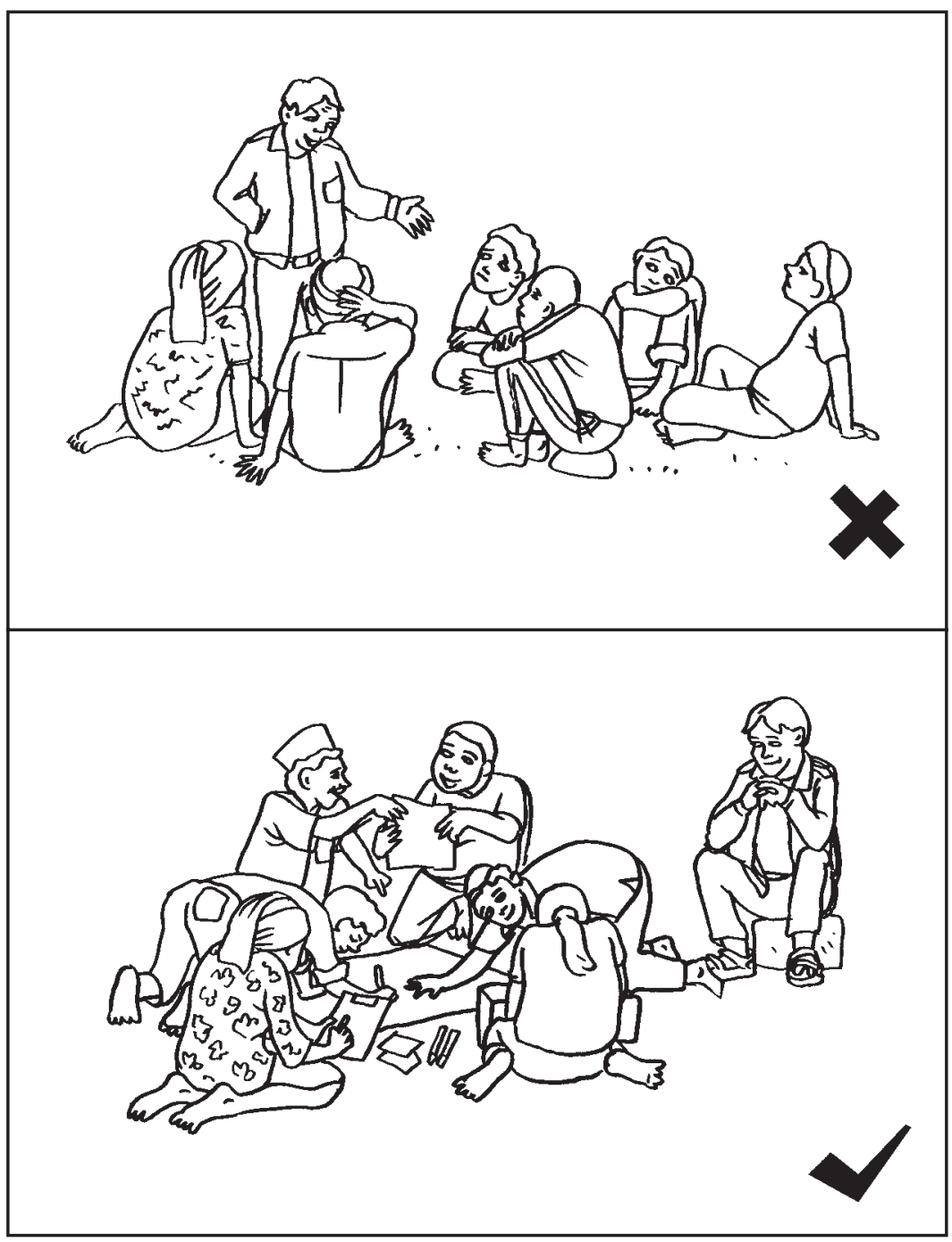


penerapannya proses-proses sosial pada tingkat lokal tidak mendapat perhatian yang memadai. Hal ini telah mengakibatkan pembagian manfaat pengelolaan hutan yang tidak adil dan justru merugikan kelompok-kelompok marginal di tingkat lokal. ${ }^{10}$

Dari perkembangan pendekatan partisipatif dalam pengelolaan hutan di Indonesia kita dapat melihat bahwa yang telah terjadi adalah proses pembelajaran "coba dan ralat" (trial and error) antara berbagai kelompok kepentingan. Pembelajaran semacam ini masih berlangsung hingga hari ini. Tetapi walaupun pembelajaran telah terjadi, laju pembelajaran tersebut berjalan lamban dan partisipasi masih dilihat terutama sebagai cara untuk memastikan agar hutan tetap dapat dijadikan sumber pendapatan dan kekayaan bagi mereka yang memiliki kekuasaan.

Kami menduga bahwa kendala utama yang menghambat pembelajaran adalah tidak berubahnya kerangka berpikir mereka yang secara sosial dan politik kuat. Penguasaan atas tanah dan sumber daya hutan dipertahankan oleh mereka yang berkuasa karena penguasaan tersebut telah memberi kenyamanan. Dapat disimpulkan bahwa pembelajaran yang terjadi sesungguhnya tidak nyata. Artinya, pembelajaran semu semacam itu tidak membawa perubahan-perubahan yang langgeng. 



\section{4}

\section{LOKASI PENELITIAN KAMI}

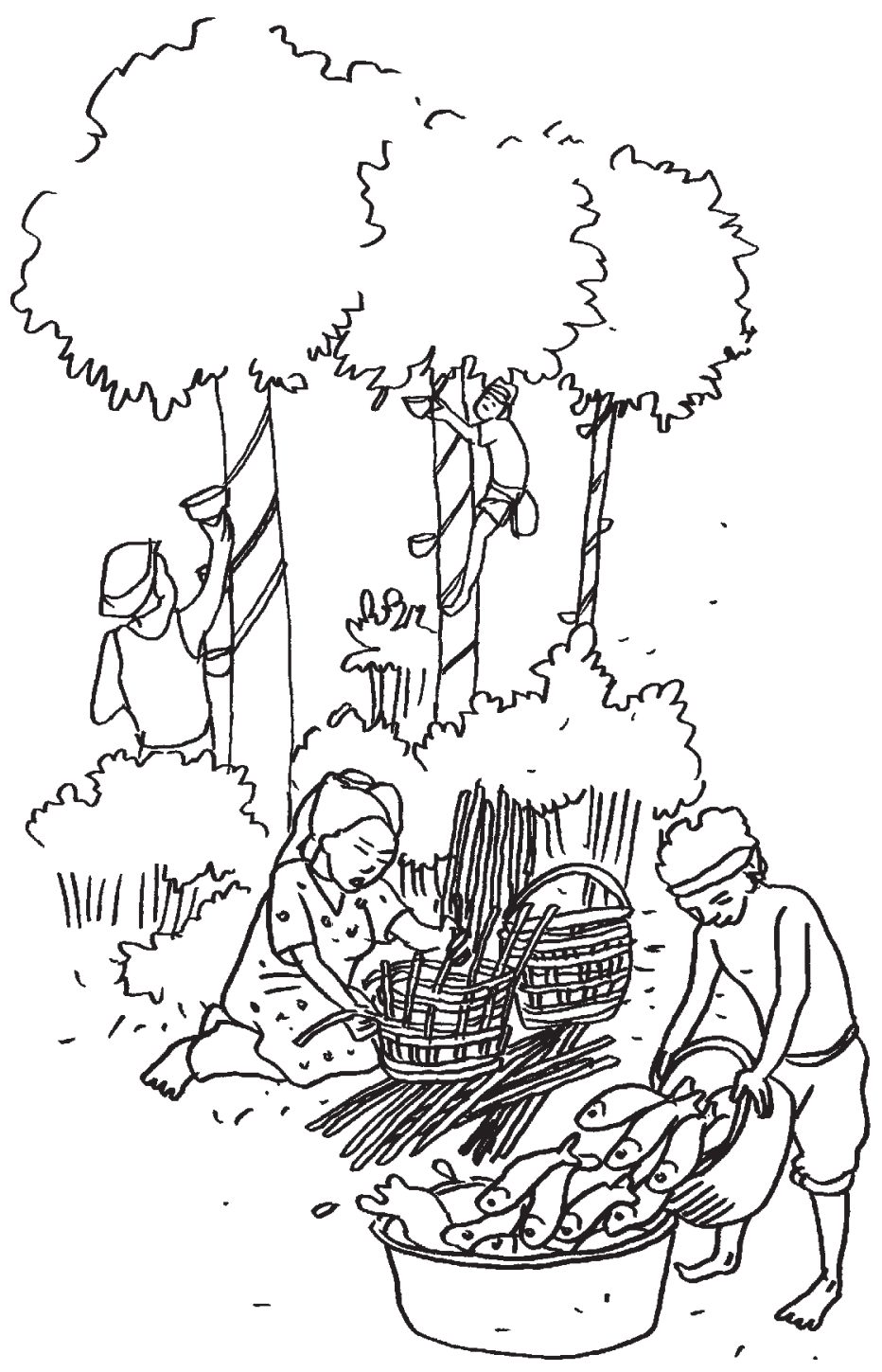


Karena merupakan makhluk yang berkesadaran, manusia tidak saja berada "dalam" dunia, tetapi juga "bersama" dunia.

(It is because he is a conscious being that man is not only "in" the world, but "with" the world.)

Paulo Freire, filsuf, ilmuwan, dan pembaharu 
Setelah pencarian yang ekstensif untuk menemukan lokasi penelitian, tim kami memilih dua tempat: Desa Baru Pelepat di Kabupaten Bungo, Propinsi Jambi, Sumatera, serta Desa Rantau Layung dan Desa Rantau Buta di Kabupaten Pasir, Propinsi Kalimantan Timur (Gambar 7).

Sementara bab sebelumnya menyampaikan konteks luas penelitian kami, dalam bab ini dipaparkan konteks lokalnya. Bab 4 ini menggambarkan lokasi penelitian, pemangku kepentingan yang berada di lokasi tersebut, dan ketidakpastian yang mereka hadapi. Selanjutnya bab ini membahas tingkat kemampuan adaptif dan kemampuan kolaboratif yang dimiliki para pemangku kepentingan tersebut karena hal ini merupakan salah satu aspek dari konteks lokal yang penting.

\subsection{Hutan dan Para Pemangku Kepentingan}

\section{Hutan dan masyarakat}

Dari lanskapnya, dengan mudah kita dapat melihat bahwa hutan di kedua lokasi penelitian telah dipengaruhi oleh berbagai kegiatan manusia: berladang, berkebun wanatani, menebang kayu, dan pada kasus di Jambi, berkebun kelapa sawit, serta transmigrasi. Hutan dipterocarp, yang dikenal memiliki nilai kayu yang tinggi seperti jenis meranti (Shorea spp.), mengelilingi desa.

Saat memasuki Baru Pelepat kami melihat bahwa sebagian besar wilayah itu tertutup oleh hutan sekunder yang hingga saat itu telah berkembang dikarenakan sistem rotasi pertanian masyarakat lokal maupun penebangan kayu skala besar. Sisa-sisa hutan primer masih dapat kami temukan di sana-sini pada daerah yang lebih tinggi dan wilayah perbukitan.

Baru Pelepat terletak sekitar 65 kilometer di sebelah timur Taman Nasional Kerinci Seblat, yang merupakan salah satu dari empat wilayah konservasi terbesar di Asia Tenggara. Luas wilayah desa adalah 7.265 hektar dan dihuni oleh 557 jiwa pada saat kami memasuki lokasi. Lokasi desa ini berada di bagian hulu Sungai Batang Pelepat sehingga merupakan bagian dari daerah tangkapan air untuk wilayah pertanian, perkebunan, dan wilayah perkotaan ke arah hilir. Tekanan akibat penebangan kayu komersial seperti jenis meranti, Parashorea aptera, dan balam (Palaquium spp.) cukup tinggi. Keanekaragaman fauna di wilayah ini tinggi.

Lokasi penelitian lainnya, Rantau Layung dan Rantau Buta, adalah dua desa yang berdampingan dan terletak di antara Gunung Lumut dan Sungai Kasungai, sekitar 202 kilometer sebelah timur Balikpapan. Jaraknya kurang lebih satu kilometer dari hutan Gunung Lumut yang pada tahun 1993 ditetapkan sebagai Hutan Lindung oleh pemerintah. Kedua desa ini terdapat di wilayah operasi beberapa 

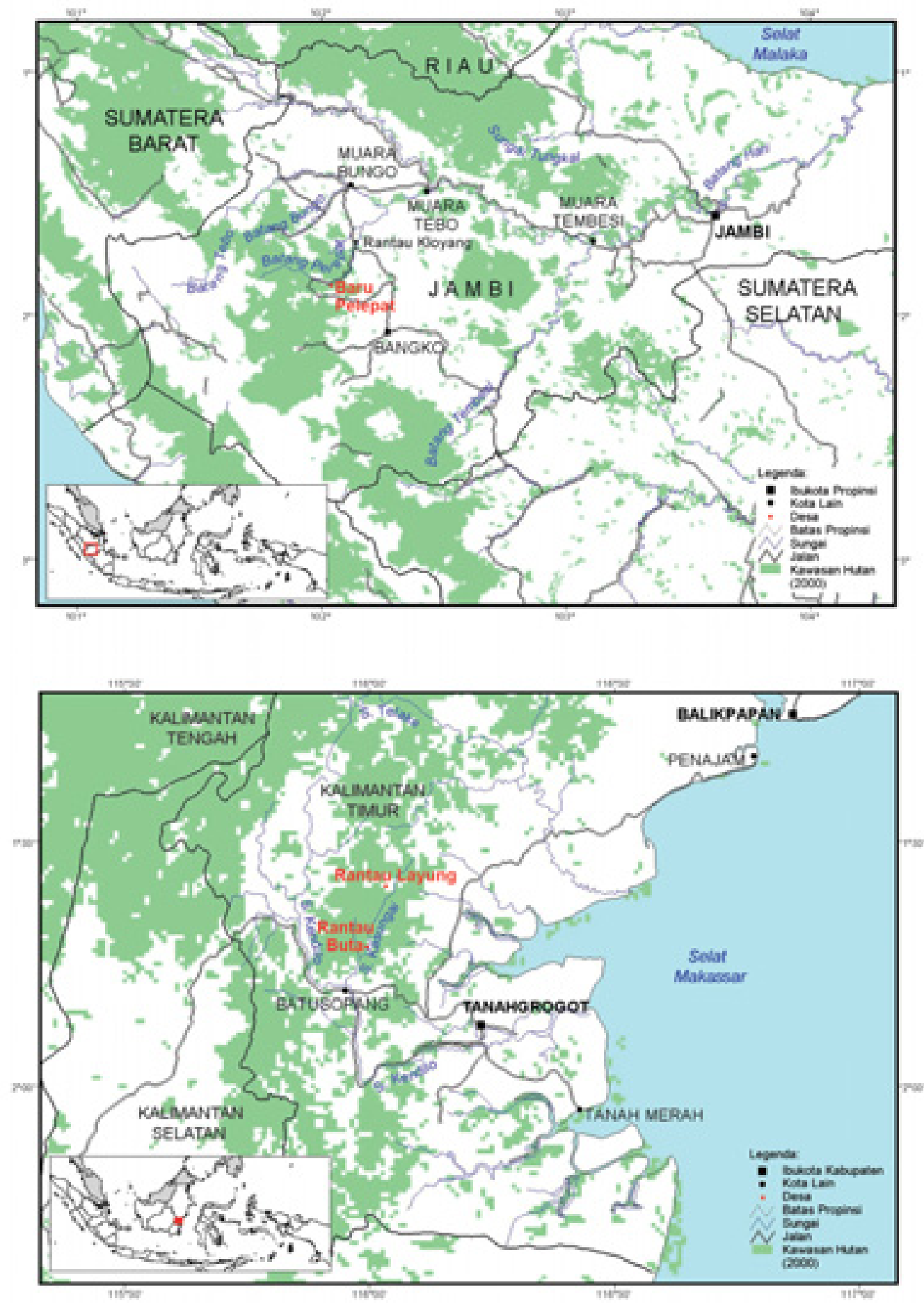

Gambar 7. Lokasi-lokasi penelitian kami 


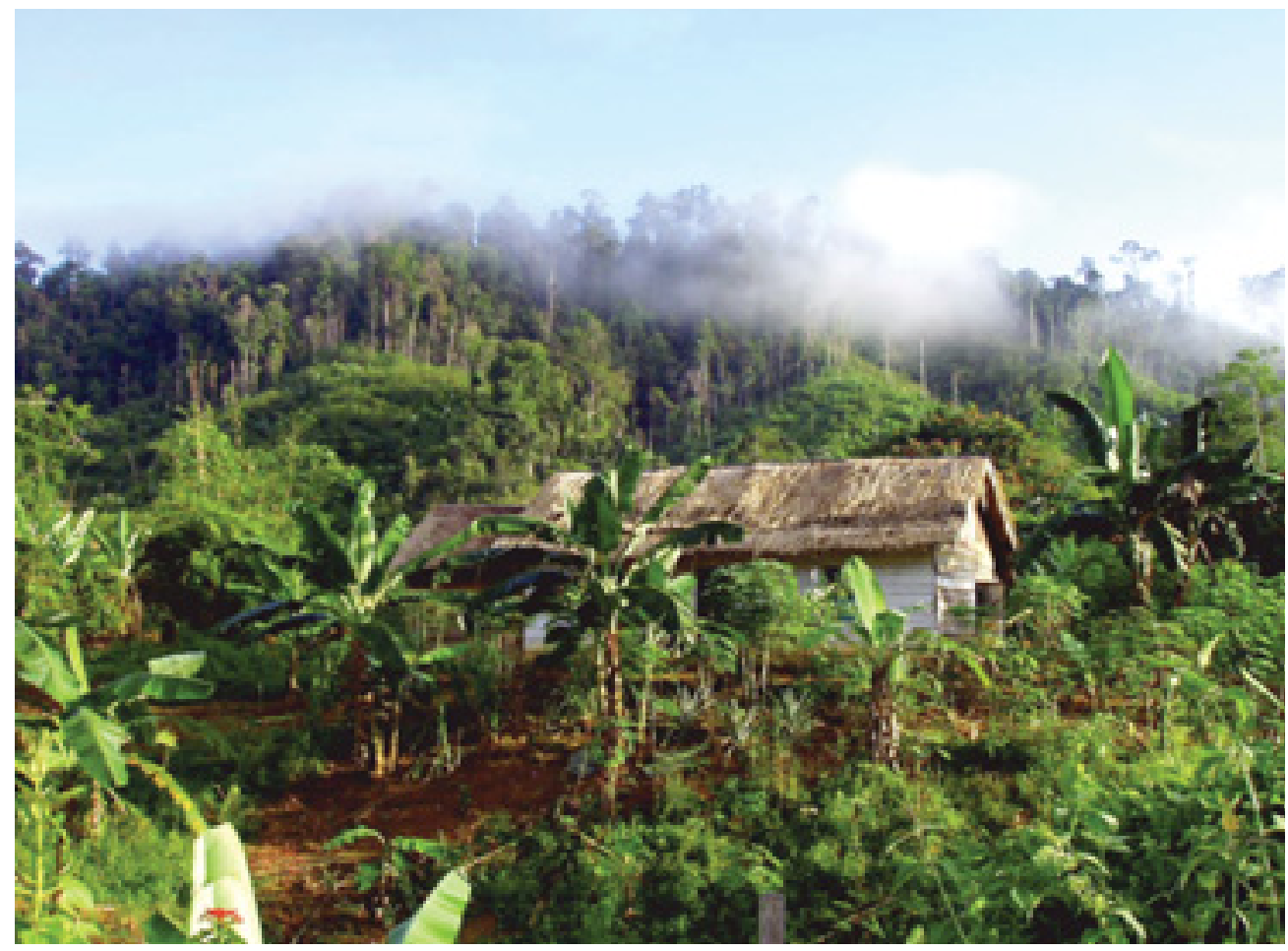

Pemandangan yang umum terdapat di lokasi penelitian di Jambi: rumah kayu yang dikelilingi kebun dan ladang dengan tanaman pangan, sementara hutan sekunder nampak di latar belakang.

perusahaan penebangan kayu skala besar. Luas wilayah Rantau Buta adalah 18.913 hektar dengan penduduk 210 jiwa, sementara Rantau Layung luasnya 16.546 hektar dan berpenduduk 85 jiwa.

Seperti halnya di Baru Pelepat, sebagian besar dari hutan di sini adalah hutan sekunder. Kami mengamati bahwa hutan mengikuti sebuah pola lanskap mosaik yang khas, yakni lahan kering pertanian berselang-seling dengan kebun-kebun wanatani masyarakat dan wilayah hutan penebangan skala besar. Hutan primer dapat ditemukan sepanjang batas hutan lindung. Vegetasi di sini mencakup wayan (Aglaia tomentosa), terap (Artocarpus elasticus), dan meranti merah (Shorea leprosula). Hewan yang umum terdapat di sini adalah rusa (seperti Cervus unicolor), burung layang-layang, dan beberapa jenis reptil.

Seperti halnya banyak komunitas yang hidup di pinggir atau di dalam hutan di Indonesia, masyarakat di ketiga desa sangat bergantung pada hasil-hasil hutan, semak belukar, lahan kering, daerah berhutan, kebun wanatani, dan pekarangan. Secara sosial, penduduk desa beranekaragam: mereka berasal dari berbagai kelompok etnis dan sosial yang berbeda. Selain itu, di dalam masyarakat terdapat perbedaan status sosial di antara individu dan di dalam kelompok. 
Kami mengamati bahwa hal tersebut telah menimbulkan ketimpangan sosial dalam hal kesejahteraan, jender, dan kekuasaan. Contoh struktur sosial yang timpang di lokasi penelitian adalah lebih tingginya status sosial para tokoh adat dibandingkan status sosial anggota masyarakat lainnya. Hal ini berarti bahwa tokoh-tokoh adat tersebut dipandang mempunyai hak yang lebih dalam pengambilan keputusan dalam masyarakat (bandingkan Kotak 1 dalam Bab 2).

\section{Berbagai pandangan masyarakat tentang hutan}

Mengingat keanekaragaman kelompok masyarakat di lokasi-lokasi penelitian kami, tidaklah mengherankan bahwa terdapat berbagai pandangan yang dimiliki masing-masing kelompok tentang penggunaan wilayah hutan dan sumber daya alam lainnya di sekitar desa mereka.

Kelompok-kelompok atau perseorangan yang berbeda mempunyai nilai yang berbeda pula terhadap hutan, seperti misalnya:

- hutan sebagai sumber makanan dan pendapatan

- hutan sebagai sumber bahan bakar dan bahan masukan untuk pertanian

- hutan sebagai milik atau investasi bagi generasi sekarang dan yang akan datang.

Berikut ini diberikan beberapa contoh pandangan yang berbeda-beda tentang pemanfaatan sumber daya hutan.

Warga masyarakat yang lebih kaya memandang hutan dari sudut pandang kepentingannya, yakni guna memperoleh manfaat dari eksploitasi hutan secara komersial yang dilakukan perusahaan penebangan kayu dari luar yang nyaris tidak peduli terhadap masyarakat lokal. Warga masyarakat tersebut bekerja sama dengan pihak luar dalam menyediakan tenaga/buruh untuk penebangan kayu. Lain halnya dengan warga desa yang lebih miskin; mereka bergantung pada hutan terutama untuk mencukupi kebutuhannya, seperti mengumpulkan buahbuahan, umbi-umbian, dan hewan buruan. Kelompok masyarakat yang relatif miskin adalah Orang Rimba di Jambi dan kaum perempuan di Pasir.

Contoh lain dari Baru Pelepat adalah perbedaan pandangan mengenai sumber daya alam terjadi antara penduduk asli dan pendatang dari Sumatera dan Jawa. Masyarakat asli setempat adalah keturunan Minangkabau yang datang ke wilayah Baru Pelepat dari Sumatera Barat lebih dari 100 tahun yang lalu. Masyarakat pendatang berada di wilayah tersebut melalui program transmigrasi pemerintah tahun 1997; dari program ini mereka telah memperoleh tanah untuk dihuni dan bertani. 


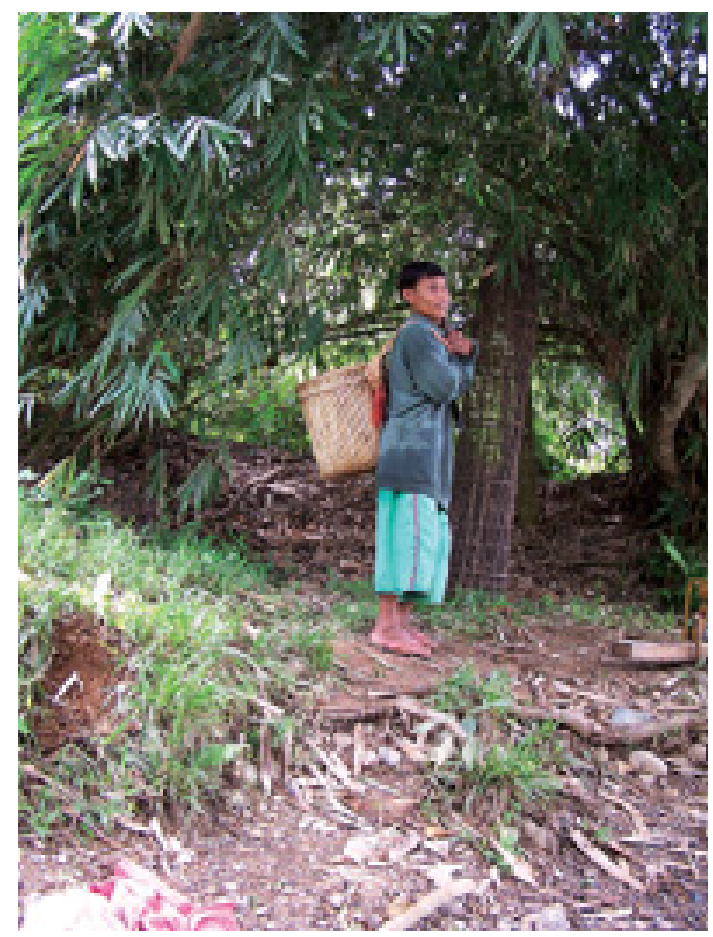

Hutan: sumber pangan dan pendapatan bagi masyarakat lokal.

Bagi warga Minangkabau, hutan merupakan sumber makanan dan pendapatan. Mereka membuka hutan untuk menanam padi, tanaman musiman lainnya, dan tanaman karet, serta memanen hasil-hasil hutan seperti kayu, rotan, dan buah-buahan.

Masyarakat pendatang, di lain pihak, memandang hutan dan semak belukar sekitar desa sebagai sumber bahan bakar dan bahan masukan untuk kegiatan pertanian mereka, seperti galah bambu atau keranjang rotan. Mereka menanam tanaman pangan dan pepohonan pada tanah yang telah diberikan pemerintah kepada mereka.

Kedatangan anggota masyarakat baru ini telah meningkatkan jumlah pengguna sumber daya alam di Baru Pelepat dan pada saat yang sama membuat masyarakat semakin beragam. Di samping itu, perbedaan pandangan di antara mereka turut menyebabkan kurangnya visi bersama di dalam masyarakat tentang bagaimana hutan dan sumber daya alam lainnya dapat dimanfaatkan.

Contoh lain bagaimana masyarakat memandang hutan secara berbeda kami ambil dari lokasi di Pasir. Keturunan Aji Sulaiman, penguasa setempat yang memimpin Kerajaan Pasir pada abad ke-19, mengaku memiliki kewenangan atas wilayah hutan yang mencakup kedua desa penelitian. Namun, pada saat kami melakukan penelitian kami, pemerintah kabupatenlah yang menjalankan kewenangan resmi berkenaan dengan pengelolaan hutan. Contoh ini menggambarkan bahwa di lokasi Pasir ada perbedaan persepsi tentang siapa yang memiliki kewenangan atas wilayah hutan.

\section{Mendefinisikan para pemangku kepentingan}

Kelompok atau perseorangan yang berbeda dalam masyarakat mempunyai pandangan masing-masing mengenai bagaimana semestinya sumber daya alam di desanya digunakan. Perbedaan pandangan ini terjadi karena mereka 
menggunakan sumber daya tersebut dengan cara yang berbeda-beda dan memberi nilai yang berbeda pula pada sumber daya tersebut. Namun pada saat yang sama, mereka menggunakan sumber daya yang sama pula. Hal ini berarti bahwa masa depan setiap kelompok dan perseorangan sangat tergantung pada sumber daya alam apa yang digunakan, keputusan apa yang diambil, dan apa yang dilakukan oleh pihak lain. Dengan kata lain, ada saling ketergantungan di antara mereka. Para pakar ilmu sosial menjelaskan ketergantungan timbal balik ini dengan mengatakan bahwa kelompok-kelompok atau perseorangan tersebut merupakan bagian dari suatu sistem, dalam hal ini sistem hutan. Kelompok-kelompok atau perseorangan itulah yang kami sebut sebagai pemangku kepentingan. Kotak 8 mendefinisikan pemangku kepentingan, sementara Kotak 9 menampilkan para pemangku kepentingan yang kami identifikasi di kedua lokasi penelitian kami. Tim kami menggunakan berbagai pendekatan untuk mengidentifikasi para pemangku kepentingan. Pendekatan-

Kotak 8. Pemangku kepentingan atas hutan

Pemangku kepentingan atas hutan adalah perseorangan, kelompok sosial, lembaga, suatu komunitas, atau kumpulan orang di dalam masyarakat yang memiliki kepentingan dalam penggunaan dan pengelolaan hutan. Dengan demikian, satu pemangku kepentingan mempengaruhi dan/atau dipengaruhi oleh keputusan dan tindakan pemangku kepentingan lainnya yang berhubungan dengan sistem hutan tersebut.

Kotak 9. Para pemangku kepentingan di dalam masyarakat desa

Desa Baru Pelepat, Jambi

- Orang Rimba (perempuan dan lakilaki)

- Masyarakat asli (perempuan dan laki-laki)

- Masyarakat pendatang (perempuan dan laki-laki)

- Elit desa

- Kaum muda

- Lembaga adat

- Pemerintah desa

- Lembaga keagamaan

- Kelompok perempuan
Desa Rantau Layung dan Desa Rantau Buta, Kalimantan Timur

- Berbagai kelompok tani (perempuan dan laki-laki)

- Kaum muda (perempuan dan lakilaki)

- Pekerja di hutan (semua laki-laki)

- Tetua desa (semua laki-laki)

- Elit desa (para pejabat pemerintah resmi dan pemimpin adat) 
pendekatan tersebut disajikan pada Lampiran 1, sedangkan Lampiran 2 berisikan beberapa alat bantu untuk mengidentifikasi pemangku kepentingan serta beberapa acuan pustakanya.

\section{Para pemangku kepentingan baru: Pihak luar}

Di atas telah digambarkan bahwa di dalam masyarakat desa terdapat berbagai pemangku kepentingan yang masing-masing mengaku berhak atas sumber daya alam di wilayah desa mereka. Namun, tim kami telah menemukan bahwa para pemangku kepentingan ternyata tidak terbatas pada kelompok dan perseorangan dari dalam masyarakat desa itu sendiri. Di masa lalu hingga saat ini pihak-pihak dari luar desa telah bermunculan dan menunjukkan minat mereka terhadap sumber daya desa. Seperti disampaikan warga desa kepada kami, dalam beberapa dasawarsa terakhir ini jumlah pemangku kepentingan dari luar desa cukup meningkat dan hal ini telah mengakibatkan meningkatnya tekanan pada sumber daya alam desa. Perkembangan ini paling jelas jika kita mengambil lokasi Jambi sebagai contoh.

Sampai sekitar 25 tahun yang lalu, hutan di sekitar desa menyediakan sumber daya alam yang melimpah untuk masyarakat Baru Pelepat. Ketika itu hanya warga keturunan Minangkabau yang tinggal di wilayah tersebut. Mereka mengandalkan pengaturan berbasiskan adat dalam memanfaatkan dan mengelola hutan.

Namun, sejak pertengahan tahun 1970-an berbagai pihak luar mulai tertarik untuk turut memperoleh manfaat dari hutan di wilayah desa, khususnya kayu. Hal ini dimulai dengan usaha berskala kecil (seperti oleh perseorangan dari desadesa tetangga) dan kemudian mencakup usaha berskala besar oleh para pengusaha hutan komersial. Untuk usaha skala besar ini berbagai perusahaan diberi ijin resmi (hak pengusahaan hutan $(\mathrm{HPH})$ ) oleh pemerintah untuk menebang kayu di wilayah tersebut. Akibatnya, berbagai pelaku luar nyaris secara terus-menerus melanggar batas-batas wilayah yang sebenarnya telah dianggap masyarakat sebagai milik mereka. Kotak 10 menunjukkan para pemangku kepentingan yang berasal dari luar masyarakat desa.

Masyarakat kemudian menyadari bahwa lembaga adat mereka ternyata tidak mampu untuk menghentikan "pelanggaran" seperti digambarkan di atas dan untuk menjaga sumber daya desa. Masyarakat juga nyaris tidak mendapat dukungan dari pemerintah dalam menjaga sumber daya mereka dari para "pengganggu" itu. Bahkan sebaliknya, pemerintah sering berpihak pada perusahaan dengan cara memberi HPH, sekalipun wilayah hutan yang bersangkutan telah dianggap masyarakat sebagai hutan mereka. Dengan begitu, penggunaan sumber daya hutan dan sumber daya alam lainnya menjadi tidak terkendali. Banyak pemangku 
kepentingan mulai memperlakukan hutan seolah-olah merupakan sumber daya bebas dengan akses terbuka (open access). Mereka kemudian bersikap bahwa jika sumber daya hutan bagaimanapun akan habis, sebaiknya mereka mengambil apa yang masih bisa diperoleh selagi sumber daya itu masih ada.

Walaupun menggunakan dan mengelola hutan pada wilayah yang sama, karena beroperasi dengan sistem pengelolaan yang berbeda, masing-masing pemangku kepentingan memiliki cara mereka sendiri dalam mengambil keputusan tentang hutan. Di satu sisi, pengelolaan hutan lokal diarahkan terutama pada usaha pemenuhan kebutuhan manusia. Di sisi lain, perusahaan dan pemerintah menerapkan suatu sistem pengelolaan hutan formal yang diarahkan terutama untuk menghasilkan pendapatan bagi mereka, sementara mengabaikan kebutuhan masyarakat. Sistem ini menggunakan aturan-aturan dan teknikteknik pengelolaan yang biasanya dikembangkan di kantor pusat perusahaan atau kantor pemerintah tanpa terlalu memperhitungkan kondisi dan kebutuhan masyarakat lokal.

Kotak 10. Para pemangku kepentingan dari luar masyarakat desa

Desa Baru Pelepat, Jambi

- Dusun tetangga, yakni Lubuk Telau

- 6 desa tetangga lainnya

- Pekerja hutan dari desa tetangga

- Pemilik penggergajian kayu dan pekerja hutan dari Baru Pelepat

- Proyek ICDP, LSM dan staf Taman Nasional Kerinci Seblat

- Pemerintah kecamatan

- Pemerintah kabupaten

- Perusahaan penebangan kayu (Inhutani V dan Koperasi Lamusa)

- $\operatorname{Tim} \mathrm{ACM}$

\section{Desa Rantau Layung dan Desa} Rantau Buta, Kalimantan Timur

- Desa-desa tetangga (Kasungai, Batu Kajang)

- Pekerja hutan dari desa tetangga

- Pemilik penggergajian kayu

- Pemerintah kecamatan

- Pemerintah kabupaten

- Perusahaan penebangan kayu (PT Telaga Mas dan Teguh Maronda Prima)

- $\operatorname{Tim}$ ACM

\section{Berbagai kepentingan yang berasal dari kebijakan pemerintah}

Keputusan dan kebijakan pemerintah sering tidak sesuai dengan bagaimana masyarakat desa memanfaatkan dan mengelola sumber daya alam di wilayah desa mereka. Kita telah melihat ketidakcocokkan semacam itu dalam contoh di atas 
ketika pemerintah memberi HPH kepada perusahaan yang beroperasi di Baru Pelepat tanpa mengakui masyarakat desa sebagai pengguna yang berhak atas sumber daya. Pada saat kami memasuki desa tersebut, masyarakat mengisahkan kembali bagaimana sejak pertengahan tahun 1970-an empat perusahaan kayu telah melakukan penebangan kayu besar-besaran di wilayah desa mereka. Tumpang tindih wilayah operasi perusahaan HPH dan wilayah desa seperti itu terjadi karena kebijakan pemerintah pada tahun 1970-an yang menetapkan berbagai luasan hutan sebagai Hutan Negara yang dikuasai oleh negara. Dalam penetapan kebijakan tersebut, pada umumnya pemerintah mengabaikan keadaan masyarakat lokal yang selama beberapa generasi telah hidup di dalam dan di sekitar wilayah hutan tersebut dan memperoleh penghidupan dari sumber daya alam di sana. Pada saat penelitian kami sekitar 60\% wilayah Desa Baru Pelepat merupakan hutan negara.

Ada dua contoh lain tentang ketidakcocokkan antara kebijakan dan penggunaan sumber daya hutan oleh masyarakat lokal yang layak kita perhatikan. Di Pasir, peraturan pemerintah kabupaten pada tahun 2000 memberi hak kepada petani secara perseorangan untuk mengambil hasil hutan dari lahan mereka sendiri, disebut IPPK (izin pemungutan dan pemanfaatan kayu). Melalui kesepakatan resmi, masyarakat Rantau Buta dan Rantau Layung "berkolaborasi" dengan perusahaan komersial yang membeli hasil hutan tersebut. Walaupun dimaksudkan untuk memberi manfaat kepada masyarakat, kebijakan itu menjadi sarana bagi

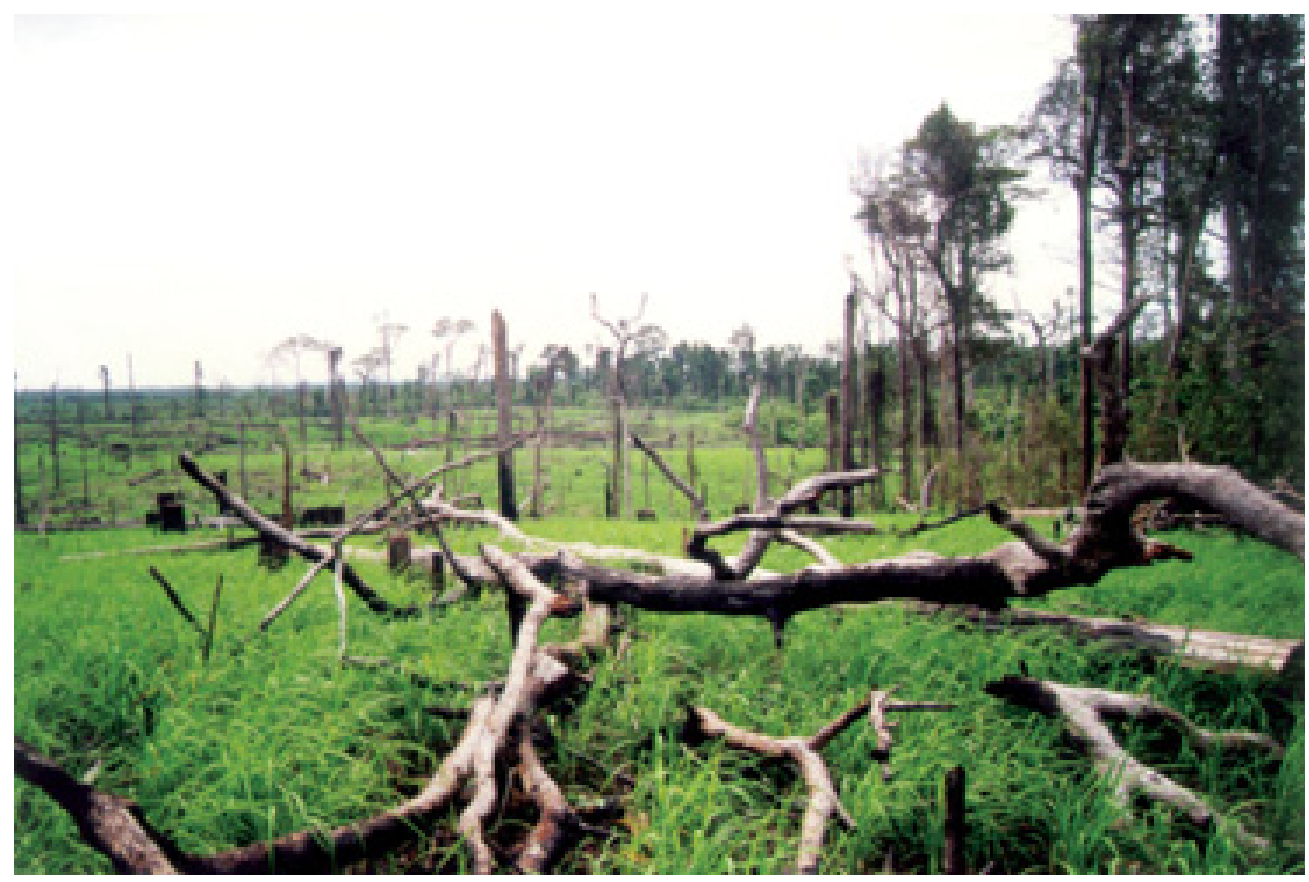

Kebanyakan lanskap hutan sudah dibuka, seperti dapat ditemukan di banyak tempat di Indonesia. 
perusahaan dan elit desa untuk memenuhi kepentingan mereka sendiri saja. Mereka melakukannya dengan mendorong petani untuk "bekerja sama" dengan perusahaan dengan cara mengajukan permohonan IPPK kepada pemerintah. Dalam prakteknya, usaha ini menghasilkan keuntungan besar bagi perusahaan dan elit desa, sementara warga masyarakat hanya memperoleh keuntungan yang tidak berarti.

Contoh kedua dari Jambi. Pada tahun 1980-an pemerintah menetapkan kebijakan nasional tentang "penyeragaman desa". ${ }^{11}$ Sesuai dengan kebijakan ini, pemerintah desa dapat ditetapkan hanya jika disetujui oleh pemerintah kabupaten. Kebijakan tersebut juga menentukan luas dan cakupan wilayah desa tanpa mempertimbangkan wilayah yang sebelumnya ditempati oleh masyarakat. Walaupun pada tahun 2001 kebijakan tersebut sudah ditarik kembali, namun bagi kelompok Minangkabau dampaknya sudah sangat jauh. Misalnya, kebijakan tersebut tidak memungkinkan lembaga adat untuk tetap mengatur kehidupan masyarakat dan penggunaan sumber daya alam. Tambahan pula, sebagian dari kelompok Minangkabau yang tinggal ke arah hilir diharuskan menjadi bagian dari desa lain; hal ini jelas memperlemah ikatan sosial yang ada di dalam kelompok Minangkabau tersebut.

Sejak awal tahun 2001, pada saat pemerintah mulai menerapkan kebijakan desentralisasi, banyak pihak mengharapkan akan terjadinya perubahanperubahan yang positif di dalam masyarakat. Kebijakan ini antara lain berarti bahwa lembaga lokal diberi kewenangan atas pengelolaan hutan di wilayah desanya. Tetapi dukungan pemerintah bagi penerapan desentralisasi ternyata sangat kurang. Akibatnya, masyarakat di kedua lokasi dibiarkan sendiri dalam menghadapi tantangan-tantangan baru dan cenderung rumit yang menyertai desentralisasi ini.

Lembaga adat yang ada di kedua lokasi penelitian ternyata tidak mampu memainkan peran koordinasi pengelolaan sumber daya hutan, maupun mengupayakan pengakuan pemerintah atas hak-hak masyarakat yang berkenaan dengan sumber daya alam. Lembaga ini juga lemah dalam menciptakan akses yang setara bagi semua pemangku kepentingan di dalam masyarakatnya sendiri. Misalnya, pada saat kami memasuki lokasi di Jambi, perempuan, Orang Rimba, dan masyarakat pendatang hampir tidak pernah dilibatkan dalam pengambilan keputusan tingkat desa. Kepentingan kelompok-kelompok ini nyaris tidak terwakili. Pada umumnya keputusan-keputusan masyarakat diambil oleh segelintir warga masyarakat yang berpengaruh, dan biasanya mereka semua lakilaki. Seperti di kebanyakan masyarakat lokal di Indonesia, lembaga lokal ternyata tidak cukup mampu untuk menangani perbedaan-perbedaan kepentingan yang ada. 
Adanya tumpang tindih kepentingan mengenai hutan dan cara-cara lama dalam pengambilan keputusan tentang sumber daya hutan menunjukkan perlunya cara pandang baru tentang bagaimana hutan seharusnya digunakan dan dikelola, baik di tingkat pemerintah maupun tingkat masyarakat.

\subsection{Konteks Pembelajaran: Menghadapi Ketidakpastian}

Tim kami melihat bahwa ada suatu kondisi yang dihadapi para pemangku kepentingan pada saat pembelajaran dan aksi ACM dimulai, yakni kondisi ketidakpastian. Karena keadaan semacam ini dapat menentukan proses pembelajaran dalam ACM, kondisi tersebut perlu mendapat perhatian lebih lanjut.

Namun apa sebenarnya yang dimaksud dengan "ketidakpastian"? Kapan kita bisa mengatakan bahwa suatu keadaan bersifat "tidak pasti"? Selama ini masyarakat di kedua lokasi penelitian dihadapkan dengan berbagai perubahan dalam lingkungan alam dan sosial yang menjadi gantungan hidup mereka. Banyak perubahan yang terjadi menimbulkan kegalauan pada diri mereka tentang masa depan mereka karena sering perubahan terjadi tak terduga. Akibatnya, menjadi sulit bagi mereka untuk memperkirakan masa depan dan merencanakannya. Nah, keadaan semacam inilah yang bisa kita sebut ketidakpastian (lihat Kotak 11). Di lokasi penelitian, kami menemukan tiga sumber ketidakpastian utama, yakni ketidakpastian karena perubahan sumber penghidupan masyarakat, perubahan hubungan sosial, dan kebijakan pemerintah.

Kotak 11. Ketidakpastian

Orang mempersepsikan bahwa mereka berada dalam keadaan yang tidak pasti ketika mereka sulit mengetahui terlebih dahulu apa yang akan terjadi. Mereka tidak dapat mengidentifikasi faktor-faktor yang pada akhirnya menentukan apa yang akan terjadi sehingga masa depan sulit diperkirakan dan karena itu juga sulit direncanakan.

\section{Perubahan-perubahan yang mempengaruhi sumber penghidupan masyarakat}

Keprihatinan utama para pemangku kepentingan di Baru Pelepat, Rantau Buta, dan Rantau Layung berkenaan dengan perubahan-perubahan yang mempengaruhi sumber penghidupan mereka. Sementara manfaat hutan bagi 
kehidupan masyarakat mengalami penurunan yang cukup besar, hanya sedikit sumber penghidupan alternatif yang tersedia. Hal ini khususnya dialami kelompok Minangkabau dan Orang Rimba di Jambi, dan kelompok Dayak Adang di Pasir.

Di masa lalu, bagi kelompok-kelompok ini hutan selalu menjadi sumber yang penting untuk memenuhi kebutuhan subsistensi dan mengatasi kekurangan pangan di masa-masa sulit. Tetapi pada saat penelitian kami, penyempitan wilayah hutan telah mengurangi kesempatan bagi masyarakat yang membuka hutan untuk memulai pertanian ladang berpindah. Penurunan ketersediaan hasil hutan juga mempengaruhi hasil pertanian masyarakat karena mereka makin sulit memperoleh hasil hutan yang diperlukan untuk kegiatan pertanian seperti serasah, pakan ternak, tempat penggembalaan ternak, dan kayu untuk peralatan pertanian. Pada akhirnya, semua itu menyebabkan menurunnya pendapatan banyak rumah tangga. Sebelumnya, sumber penghasilan rumah tangga itu berasal dari penjualan hasil hutan seperti rotan dan kayu, hasil pertanian, pekerjaan sebagai buruh, atau penjualan barang-barang seperti anyaman keset dan keranjang yang berbahan baku dari hutan. Gambar 8 menggambarkan penurunan ketersediaan hasil hutan di lokasi kegiatan kami, termasuk skenario masa depan, sebagaimana dilihat oleh kelompok-kelompok masyarakat desa.

\section{Perubahan-perubahan dalam hubungan sosial}

Sumber ketidakpastian lain yang dihadapi para pemangku kepentingan di kedua lokasi penelitian adalah terjadinya berbagai perubahan dalam hubungan antara individu, kelompok, atau lembaga. Kadangkala ketidakpastian ini muncul karena berubahnya sifat dari hubungan yang telah ada, sementara dalam kasus lain ketidakpastian terjadi karena terbentuknya hubungan baru. Kami berikan contoh dari lokasi di Baru Pelepat untuk menggambarkan kedua macam ketidakpastian ini.

Ketika masyarakat Minangkabau masih merupakan satu-satunya kelompok penduduk di Baru Pelepat, lembaga adat mereka mengatur penggunaan sumber daya alam, hak dan kewajiban anggota masyarakat, serta hubungan antara para pemangku kepentingan. Tetapi peran pengaturan ini berubah ketika pada awal tahun 1980-an kebijakan pemerintah tentang "penyeragaman desa" menentukan bahwa lembaga adat harus berbagi kewenangan dengan pemerintah desa yang ditunjuk secara resmi (lihat juga hlm. 50).

Keadaan itu bertambah rumit ketika banyak warga masyarakat merasa tidak puas terhadap beberapa pemimpin adat yang menurut mereka hanya mementingkan diri mereka sendiri. Jadi, lembaga adat yang semestinya mengatur kehidupan 

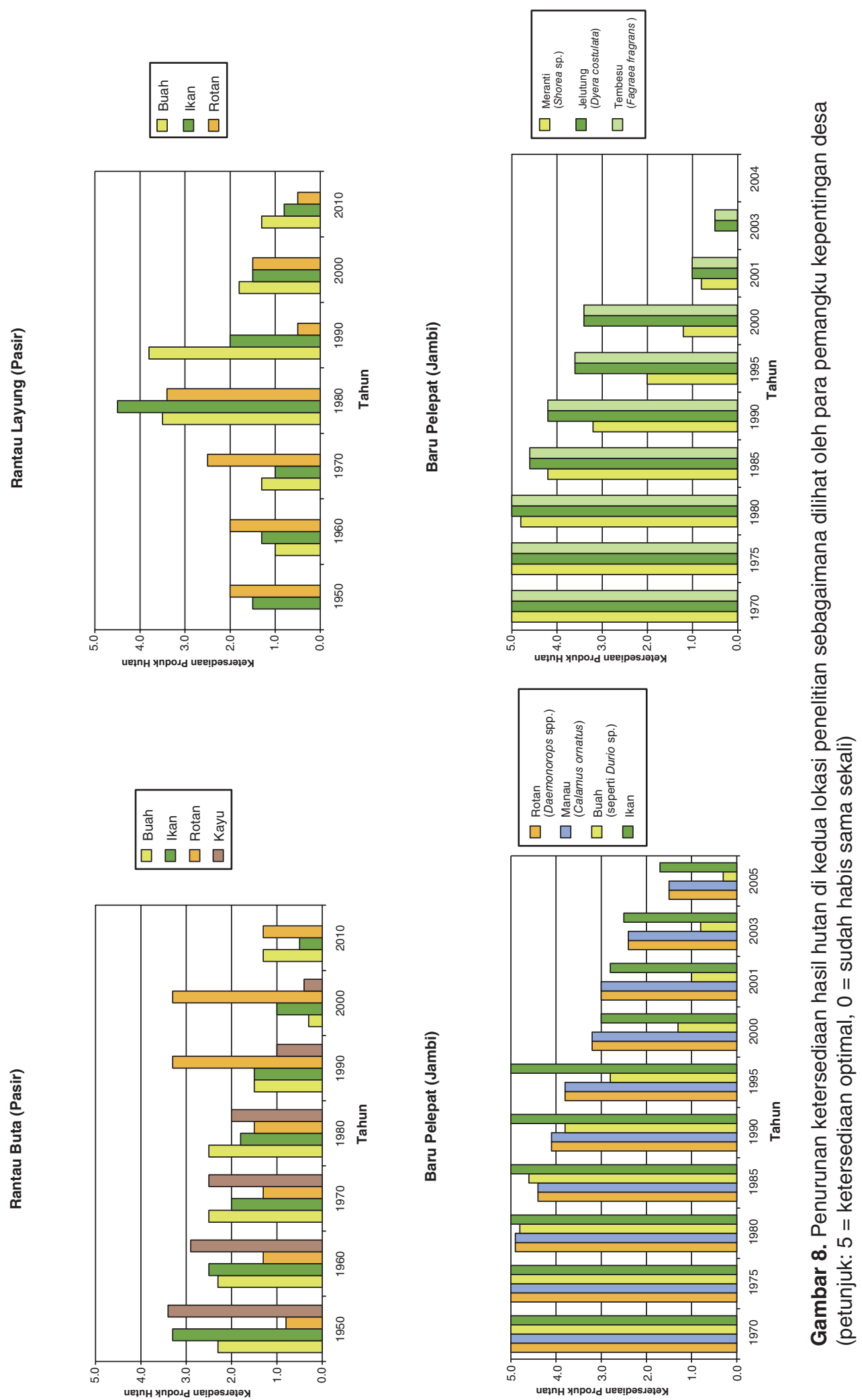


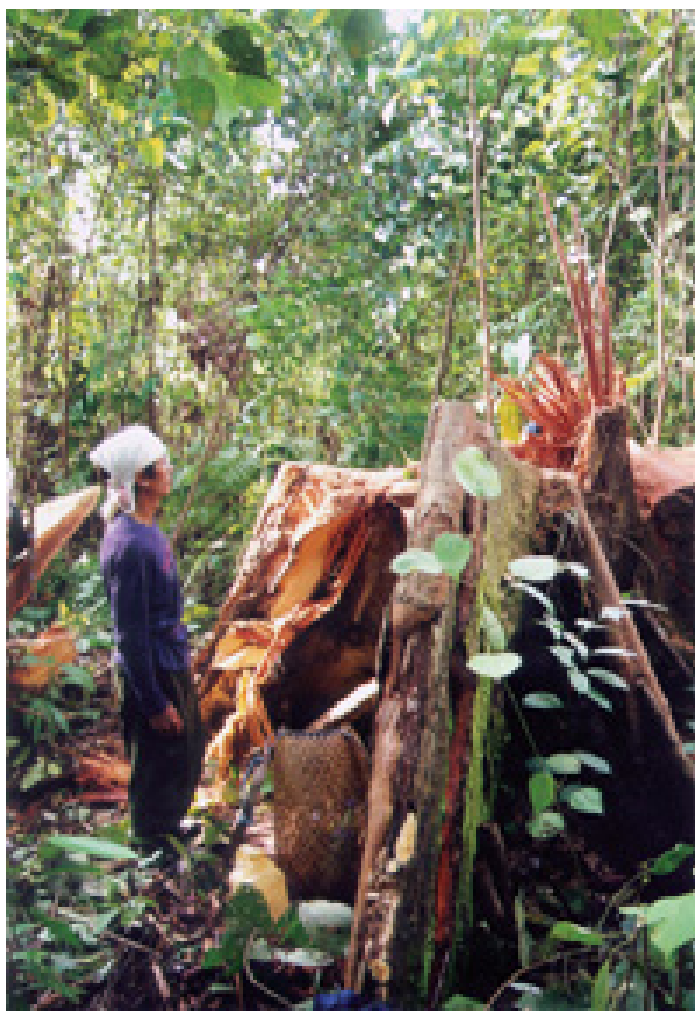

Ketidakpastian karena menurunnya sumber penghidupan telah mengakibatkan akses terbuka (open access) terhadap sumber daya hutan: warga desa sering mengatakan, "Tebanglah pohon sebelum orang luar melakukannya."

masyarakat, justru kehilangan kepercayaan dan kewenangan yang pernah dimilikinya di masa lalu. Akibat melemahnya rambu-rambu adat, perilaku warga masyarakat menjadi sulit diperhitungkan jika saling berhubungan (lihat Kotak 12). Akibat lebih jauh lagi, hubungan sosial antarwarga melemah.

Sementara itu, pada tahun 1997 melalui program transmigrasi pemerintah menempatkan kelompok etnis dan kelompok sosial lain di Baru Pelepat. Kelompok-kelompok tersebut menjadi bagian dari masyarakat desa. Kehadiran kelompok baru itu menciptakan hubungan sosial baru dan adanya pandangan hidup dan norma sosial yang berbeda-beda. Perubahan-perubahan tersebut sering menciptakan situasi yang kabur. Dalam situasi tersebut niat satu pihak tidak jelas bagi pihak lainnya dan perilaku satu pihak tidak dapat diperkirakan pihak lainnya. Dengan kata lain, kehadiran kelompok-kelompok baru telah menciptakan kondisi yang tidak pasti bagi warga masyarakat.

\section{Perubahan yang berasal dari kebijakan pemerintah}

Para pemangku kepentingan dalam masyarakat di kedua lokasi pengkajian juga harus menghadapi berbagai ketidakpastian yang merupakan dampak sosial, ekonomi, dan politik dari kebijakan-kebijakan pemerintah. Misalnya, seperti dicatat sebelumnya, kebijakan pemerintah menentukan bahwa hutan di sekitar desa adalah hutan negara sementara masyarakat menganggapnya sebagai hutan desa mereka. Artinya, kedua pihak (pemerintah dan masyarakat) masing-masing menuntut hak mereka atas pemanfaatan hutan. Masyarakat melihat hutan sebagai sumber penghidupan penting, sementara pemerintah melihat hutan sebagai sumber daya yang bisa dieksploitasi. Sesuai dengan pandangan pemerintah itu, sejak pertengahan tahun 1970-an pemerintah memberi konsesi hutan kepada 
Kotak 12. Ketidakpastian tentang perilaku dan tindakan pihak lain

Suatu malam, tidak lama setelah tim kami tiba di Baru Pelepat, sekelompok kecil warga desa laki-laki berkumpul di rumah kepala desa hingga larut malam. Mereka mendiskusikan kejadian beberapa hari sebelumnya ketika seorang tokoh masyarakat tertangkap mengambil kayu berharga dari hutan desa mereka. Walaupun mereka sepakat bahwa tokoh itu telah melakukan kesalahan karena mengambil kayu tanpa persetujuan warga masyarakat lainnya, namun karena ia orang yang berpengaruh dan terpandang di masyarakat, tidak seorang pun berani menuntut agar ia mempertanggungjawabkan tindakannya. Selain itu, saat itu tidak ada pihak yang berwewenang dalam masyarakat yang dapat menuntut tokoh masyarakat tersebut.

Para warga desa tersebut tidak tahu apa yang harus mereka lakukan karena mereka sulit menilai apa konsekuensinya jika mereka menuduh warga masyarakat tersebut melakukan kesalahan. Lebih dari itu, sulit bagi mereka untuk memperkirakan bagaimana tokoh masyarakat itu akan bereaksi jika dituduh; misalnya apakah ia akan melakukan pembalasan. Mereka juga mencoba membayangkan apa dampak terbesar yang mungkin akan dirasakan masyarakat: kerugian materi dan peluang finansial berkaitan dengan kayu curiannya, ataukah "kerugian emosional" yang akan terjadi jika sang "pencuri" bereaksi dengan cara yang mungkin akan berdampak negatif terhadap masyarakat. Memang dapat dibayangkan bahwa kalau sang "pencuri" dipermalukan, apapun bisa dilakukannya sebagai pembalasan.

para penebang kayu komersial, yakni perusahaan, koperasi, maupun perseorangan. Akibatnya, sejak kira-kira 25 tahun silam masyarakat mulai merasakan tekanan terhadap hutan dan mengkhawatirkan penebangan hutan oleh pihak luar (lihat Kotak 13).

Di Baru Pelepat tumpang tindih antara hak negara dan hak masyarakat juga membuka peluang untuk mengkonversi sebagian wilayah masyarakat menjadi wilayah proyek pemukiman transmigran.

Pada tahun 1985 Baru Pelepat menjadi unit administratif dalam hirarki pemerintahan. Sesuai dengan kebijakan ini, pemerintahan desa menjadi tanggung jawab resmi pemerintah desa yang baru, sementara lembaga adat terkesampingkan. Implikasi dari kebijakan pemerintahan tersebut, secara resmi dilakukan penataulangan batas desa. Akibatnya, masyarakat Minangkabau terpecah menjadi dua bagian: satu bagian digabungkan dengan masyarakat desa tetangga. Dapat dipahami bahwa kebijakan pemerintah ini melemahkan kohesi sosial masyarakat Minangkabau di wilayah ini. 


\section{Kotak 13. Ketidakpastian karena kebijakan}

Ketika kami memasuki Baru Pelepat pada awal penelitian kami, warga desa mengisahkan bahwa sejak perusahaan pertama mulai beroperasi pada pertengahan tahun 1970-an, sudah ada empat perusahaan penebangan kayu yang beroperasi di sekitar Baru Pelepat. Dalam upayanya memanfaatkan kayu berharga, perusahaanperusahaan itu menebang kayu di wilayah hutan yang cukup luas di sekitar desa. Selama itu masyarakat diabaikan dan tidak sekali pun warga masyarakat diberitahukan tentang akan beroperasinya perusahaan-perusahaan itu, apalagi dimintai persetujuannya.

Pernah ada pembicaraan informal dengan pekerja perusahaan yang memberi pemahaman kepada warga desa bahwa perusahaan-perusahaan tersebut memiliki ijin pemerintah untuk melakukan penebangan kayu. Mereka diberitahukan bahwa hutan yang sedang ditebang berada di bawah penguasaan negara dan karenanya siapa pun yang ingin menggunakan hutan harus mendapat persetujuan pemerintah. Padahal selama itu warga masyarakat mengira bahwa hutan adalah milik masyarakat adat mereka. Karena penebangan terus berlangsung dan kayu dalam jumlah besar terus dikeluarkan dari hutan, masyarakat mulai cemas. Mereka mulai mengkhawatirkan masa depan mereka dan mempertanyakan apakah yang akan didapatkan mereka maupun generasi mendatang jika hutan tidak ada lagi.

Masyarakat Rantau Buta dan Rantau Layung di Pasir mempunyai pengalaman yang hampir sama seperti masyarakat Baru Pelepat. Ketika pada tahun 1993 Menteri Kehutanan memutuskan bahwa sebagian hutan di Gunung Lumut menjadi Hutan Lindung secara resmi, masyarakat tidak dilibatkan ataupun diberitahukan bahwa keputusan semacam itu akan diambil. Pada suatu hari di tahun tersebut, sebagaimana dikisahkan beberapa anggota masyarakat, mereka menemukan beberapa patok tanda tapal batas dipancangkan di kebun wanatani mereka, yang berarti bahwa sebagian dari kebun mereka itu telah dijadikan wilayah Hutan Lindung resmi. Kehilangan sumber utama hidup mereka menimbulkan perasaan tidak pasti bagi anggota masyarakat.

Terakhir, kebijakan pemerintah tentang desentralisasi yang diberlakukan sejak awal 2001 juga ikut menciptakan kondisi baru dan tidak pasti bagi masyarakat desa di kedua lokasi. Di bawah kebijakan desentralisasi tersebut, masyarakat desa diharapkan mengambil tanggung jawab atas pengelolaan dan pelestarian sumber daya alam mereka serta berkontribusi pada pembangunan sosial dan ekonomi di desa mereka. Dalam memenuhi tuntutan tanggung jawab tersebut, masyarakat di lokasi Pasir dan Jambi merasa bahwa perhatian dan bantuan pemerintah yang mereka dapatkan sangat kurang. 


\subsection{Mengapa para Pemangku Kepentingan Kurang Mampu Beradaptasi dan Berkolaborasi?}

Pada awal penelitian, kami melihat bahwa ada kebutuhan akan suatu mekanisme yang memungkinkan para pemangku kepentingan menyesuaikan pandangan dan perilaku lama mereka dengan perubahan-perubahan yang terjadi. Selain itu mereka juga perlu mengembangkan kemampuan untuk bekerja sama dalam menghadapi perubahan-perubahan itu. Namun, tidak lama setelah mulai menetap di lokasi penelitian, kami menemukan bahwa mekanisme semacam itu tidak ada. Baiklah, mari kita cermati mengapa demikian.

\section{Kurangnya kemampuan beradaptasi}

Kami mengamati bahwa kurangnya kemampuan beradaptasi terdapat baik pada pemangku-pemangku kepentingan yang bersifat kolektif maupun individual. Contoh hal yang pertama adalah masyarakat, instansi pemerintah dan perusahaan kayu secara bersama di Pasir, sementara contoh hal yang kedua adalah tokoh adat di Jambi.

Terdapat tiga hal yang menurut kami dapat menjelaskan keadaan ini. Pertama, lembaga lokal dan instansi-instansi pemerintah sangat lemah dalam mengkoordinasikan pola-pola pengelolaan sumber daya yang ada. Karena itu, tidak ada dasar struktural bagi para pemangku kepentingan untuk bertindak dengan cara terkoordinasi dalam menghadapi perubahan sosial dan perubahan alam yang rumit. Karena kelemahan koordinasi itu, baik di tingkat masyarakat maupun di tingkat pemerintah kabupaten, para pemangku kepentingan tidak dapat menilai perubahan-perubahan yang terjadi secara sistematis sehingga tidak mampu mencari strategi untuk menghadapinya secara efektif.

Kedua, tidak ada mekanisme yang dapat membantu para pemangku kepentingan untuk belajar bersama dari aksi mereka sebagai kelompok dalam mengelola sumber daya alam. Karena itu mereka tidak dapat menilai akibat dari tindakan atau keputusan yang telah diambil. Pemantauan secara sadar dan terencana hampir tidak pernah dilakukan sehingga masukan yang dapat digunakan sebagai dasar keputusan untuk menentukan tindakan berikutnya nyaris tidak ada. Setiap pihak mengambil keputusan dan bertindak menurut pola pengelolaan masing-masing dan jarang berbagi informasi dan pengetahuan dengan pihak lain.

Ketiga, adanya ketimpangan dalam distribusi informasi antara para pemangku kepentingan. Pada gilirannya hal ini tidak mendukung terjadinya umpan-balik (feedback) informasi. Contohnya adalah keterbatasan arus informasi antara kelompok Orang Rimba dan para penanam modal dari luar desa. Masing-masing 
pihak ini mempunyai pola pengelolaan sumber daya sendiri dan hampir tidak pernah berbagi informasi. Lain halnya dengan para penebang kayu di desa dan para penanam modal dari luar desa: mereka berbagi informasi secara intensif karena keduanya merupakan bagian dari sistem pengelolaan hutan yang sama.

Ketiga hal di atas, berdasarkan pengamatan kami, disebabkan oleh tetap berkutatnya pemangku-pemangku kepentingan dalam cara-cara pandang lama tentang lingkungan alam dan sosial mereka. Akibatnya, peluang untuk mencari dan mempelajari cara-cara baru menjadi sangat terbatas. Sering para pemangku kepentingan yang "enggan belajar" ini adalah mereka yang sudah lama memiliki hak istimewa dalam mengatur kehidupan masyarakat, seperti para tokoh masyarakat dan pejabat pemerintah.

\section{Terbatasnya kemampuan berkolaborasi}

Tidak lama setelah mulai berhubungan dengan masyarakat di lokasi penelitian, kami menemukan bahwa terbatasnya kolaborasi terjadi karena beberapa faktor. Pertama, di kedua lokasi hubungan antara para pemangku kepentingan maupun hubungan dalam kelompok-kelompok pemangku kepentingan tertentu ternyata lemah. Kepercayaan timbal balik antara para pemangku kepentingan sangat kurang dan jaringan-jaringan sosial di antara mereka hampir tidak ada. Beberapa hal yang melatarbelakangi lemahnya hubungan tersebut:

- Hubungan antara pengambil keputusan dengan pemangku kepentingan lainnya pada umumnya didasarkan pada hubungan kewenangan (misalnya, hubungan antara tokoh adat dan anggota masyarakat lainnya, atau hubungan antara masyarakat dan pemerintah kabupaten). Hubungan semacam ini sangat rapuh karena tidak banyak memberikan ruang untuk rasa saling percaya dan saling menghargai.

- Latar belakang sosial-budaya para pemangku kepentingan yang berbeda-beda mengakibatkan terbatasnya komunikasi di antara mereka.

- Latar belakang sejarah. Misalnya, masyarakat di lokasi Pasir pernah terlibat secara tidak sengaja dalam gerakan politik yang mengakibatkan adanya ketidakpercayaan terhadap mereka di kalangan pemerintah.

- Konteks legal dan kebijakan. Sebagai contoh, oleh karena kebijakan transmigrasi mengalokasikan tanah kepada pendatang, penduduk asli merasa cemburu terhadap para pendatang.

Kedua, kami juga mengamati bahwa faktor lain yang menyebabkan terbatasnya kerja sama antara pemangku kepentingan, adalah lemahnya komunikasi di antara mereka. Walaupun lemahnya komunikasi itu sebenarnya terkait dengan lemahnya hubungan sosial (yang sudah dibahas di atas), karena penting perlu dijelaskan secara terpisah di sini. Kami melihat bahwa masing-masing pemangku kepentingan 


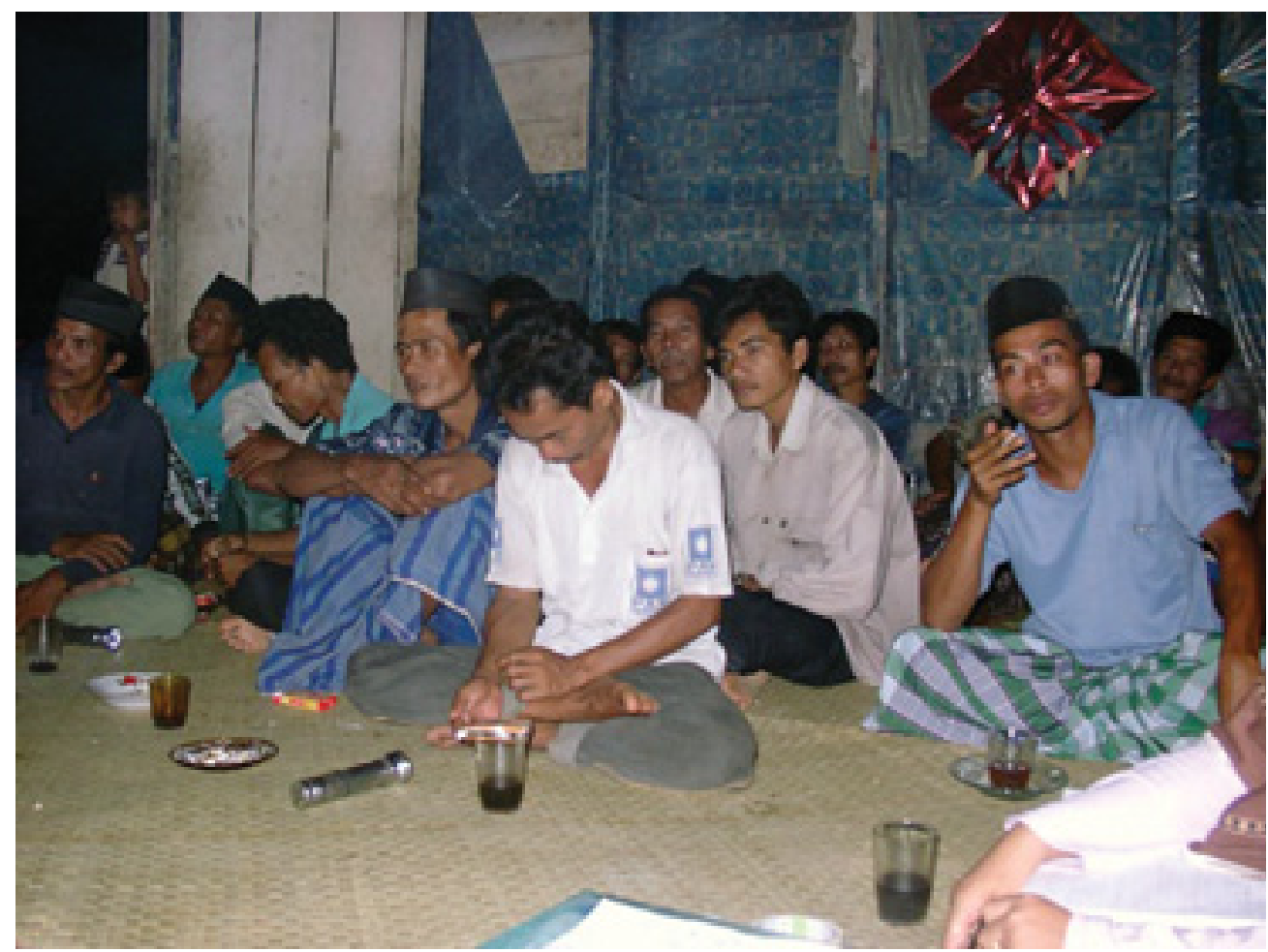

Foto ini menunjukkan suasana pertemuan yang umum terjadi ketika tim kami baru saja datang di lokasi. Proses pertemuan cenderung menjemukan dan perempuan kurang terwakili, kalaupun ada yang diundang.

tidak saja memiliki kemampuan komunikasi yang berbeda, tetapi sering juga dianggap berbeda kemampuan komunikasinya oleh pihak lain. Akibatnya, sering kita temukan bahwa ada pemangku kepentingan tertentu yang dipandang lebih layak untuk diajak berkomunikasi dibandingkan pihak lain. Contohnya, di kedua lokasi, ketika kami memulai penelitian, secara umum perempuan dianggap oleh masyarakat sebagai pihak yang kurang mampu berkomunikasi. Hal tersebut bukan karena dalam kenyataannya memang demikian, misalnya karena kurangnya pengetahuan perempuan, tetapi lebih karena budaya setempat menilainya demikian. Banyak warga masyarakat meyakini bahwa peran utama perempuan adalah mengurus rumah tangga dan membesarkan anak dan karenanya dianggap hanya memiliki sedikit pengetahuan selain tentang urusan rumah tangga dan keluarga. Akibatnya, perempuan nyaris tidak dilibatkan dalam pengambilan keputusan tingkat desa.

Terakhir, kami melihat bahwa lemahnya peran lembaga-lembaga lokal dalam mengkoordinasikan pemanfaatan dan pengelolaan hutan mengakibatkan tidak berkembangnya dasar struktural bagi para pemangku kepentingan untuk berkolaborasi. 



\section{Bagian Tiga}

\section{Praktek}

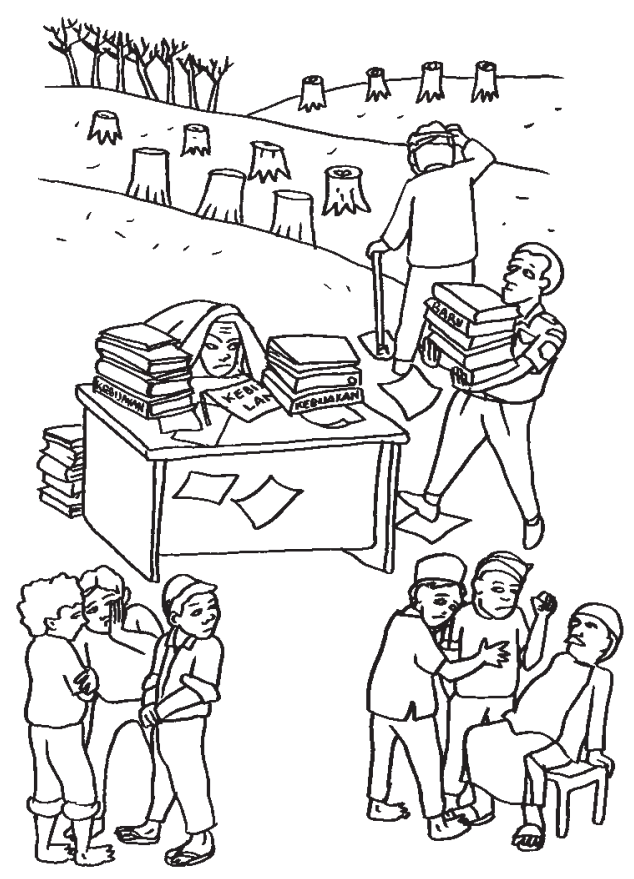

Bagian Dua telah menggambarkan konteks penelitian dan penerapan ACM kami. Dalam Bagian Tiga ini kami hendak berbagi pengalaman tim kami dalam menerapkan pendekatan ini guna memfasilitasi pembelajaran bersama di antara pemangku kepentingan di lokasi penelitian. Bagian ini dimulai dengan menggambarkan cara kami mendampingi para pemangku kepentingan dalam menerapkan ACM dan dengan menyajikan penilaian kami terhadap keluarannya (Bab 5).

Kemudian kita akan mendiskusikan tantangan yang dihadapi tim kami ketika menerapkan ACM, keunggulan pendekatan ini, maupun keterbatasannya sebagaimana kami alami (Bab 6).

Selanjutnya, kami menyampaikan pelajaran yang dapat kami petik dari pengalaman dalam menerapkan ACM, termasuk nilai tambah yang ditawarkan pendekatan ini bagi pengelolaan hutan di Indonesia (Bab 7). 



\section{5}

\section{MEMPRAKTEKKAN ACM}

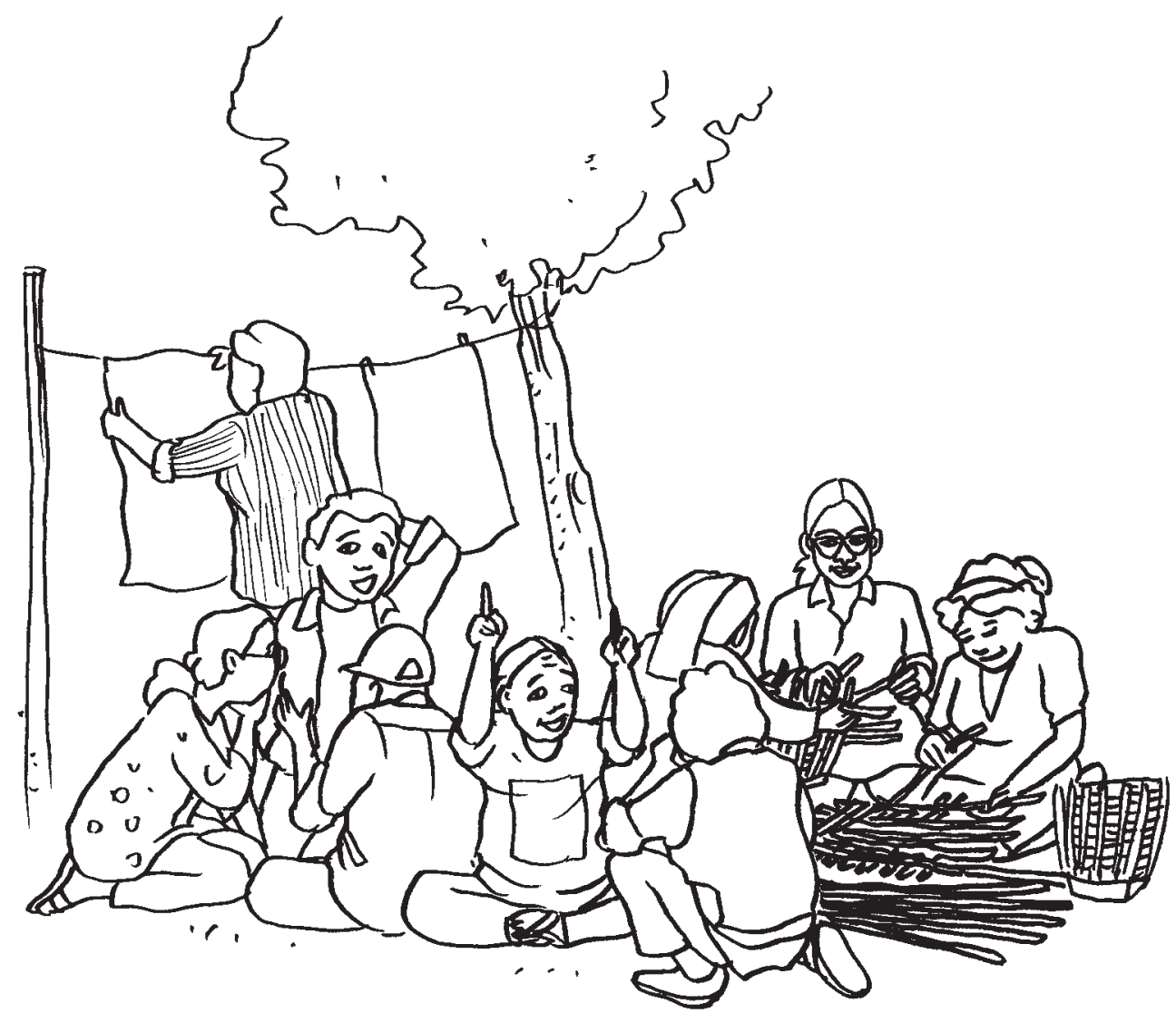




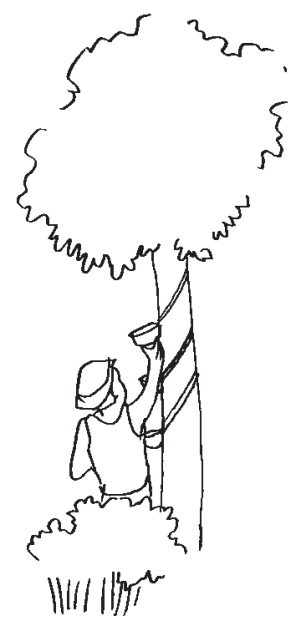

Hiduplah bersama masyarakat: tinggallah bersama mereka, belajarlah dari mereka, cintailah mereka, mulailah dengan apa yang mereka ketahui, bangunlah di atas apa yang telah mereka miliki. Tentang pemimpin yang terbaik, ketika pekerjaan terselesaikan, tugas-tugas terlaksana, warga masyarakat akan berkata, "Kami sendirilah yang telah melakukannya."

Lau Tzu, begawan Tao 
Pada bab terdahulu kami telah menggambarkan konteks penerapan dan penelitian ACM yang kami lakukan. Dalam Bab ini kami akan berbagi pengalaman dalam menerapkan pendekatan ini di lapangan mapun penilaian kami tentang keluarannya. Pengalaman kami ini secara umum berkenaan dengan penciptaan kondisi yang memungkinkan para pemangku kepentingan belajar bersama dan mengadaptasi cara mereka mengelola lingkungan alam dan sosial mereka.

\subsection{Cara Kami Menciptakan Kondisi yang Memungkinkan Pembelajaran Multipihak}

Ketika tim kami mulai terlibat dalam masyarakat di kedua lokasi penelitian, warga desa menghadapi ketidakpastian akibat menghilangnya hutan mereka, berubahnya hubungan antara para pemangku kepentingan dalam masyarakat, dan diterapkannya berbagai kebijakan pemerintah. Terdorong oleh keadaan ini, para pemangku kepentingan termotivasi untuk belajar bagaimana meningkatkan penghidupan mereka dan menghadapi keadaan yang tidak pasti itu, dan untuk itu kami diminta untuk mendampingi mereka.

Seperti telah kita lihat sebelumnya, pembelajaran adalah jiwa dari ACM. Jika kami menggunakan kata "pembelajaran", yang kami maksudkan adalah upayaupaya para pemangku kepentingan dalam memahami dunia di sekitar mereka maupun proses yang mereka tempuh untuk mencari gagasan dan pemahaman baru. Karena dalam hal ACM pembelajaran berlangsung ketika para pemangku kepentingan saling berinteraksi di antara mereka, pembelajaran ini disebut "pembelajaran sosial". Pembelajaran semacam ini terjadi ketika para individu atau kelompok dengan pandangan yang berbeda saling berinteraksi serta bertukar pikiran, gagasan, atau pengetahuan sehingga pandangan lama bisa diadaptasi atau pandangan baru dibentuk. Kotak 14 menguraikan definisi "pembelajaran" kami.

Kotak 14. Mendefinisikan "pembelajaran"

"Pembelajaran" terjadi ketika seseorang mencoba memahami dunia di sekitarnya. Manakala orang atau kelompok dengan berbagai cara pandang bertemu kita bisa berbicara tentang "pembelajaran sosial". Cara pandang lama bisa saja disesuaikan atau pandangan baru dibentuk karena pertukaran pemikiran, gagasan, atau pengetahuan di antara mereka. 
Terdapat tiga macam kegiatan utama yang diperlukan dalam menciptakan kondisi pembelajaran antara para pemangku kepentingan (lihat Gambar 9):

- Mempersiapkan pembelajaran

- Mengorganisasikan pembelajaran

- Memfasilitasi pembelajaran

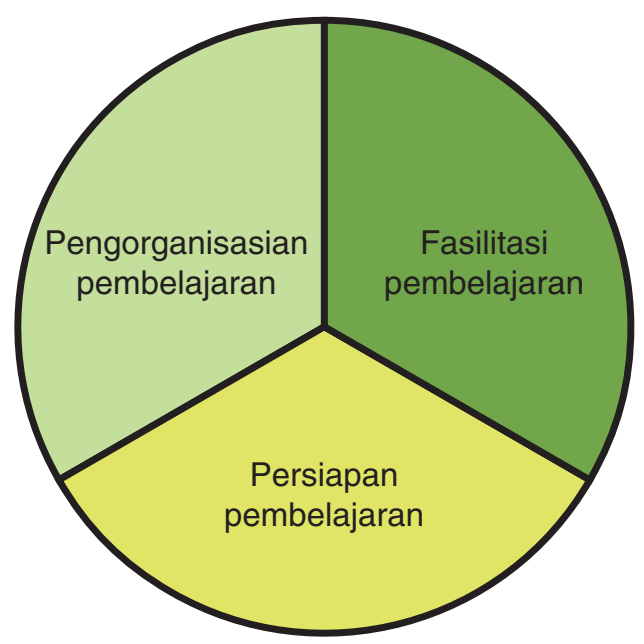

Gambar 9. Tiga jenis kegiatan guna menciptakan kondisi pembelajaran

\section{Mempersiapkan pembelajaran}

Tujuan utama dari kegiatan ini adalah untuk:

- Membangun hubungan dengan para pemangku kepentingan lokal

- Mengenali konteks pembelajaran

- Mengidentifikasi pokok-pokok permasalahan yang ingin ditangani bersama oleh para pemangku kepentingan

Di dalam kegiatan ini, membangun hubungan dengan pemangku kepentingan lokal dan mengenali konteks lokal sangat penting apabila ACM dipraktekkan oleh "orang luar" (seperti tim kami). Namun mengidentifikasi pokok-pokok permasalahan merupakan hal penting terlepas dari apakah "orang luar" ataupun "orang dalam" yang mendampingi dalam penerapan ACM. Di lapangan kami tidak terlalu membedakan pemisahan dan urutan ketiga kegiatan persiapan pembelajaran ini: dalam prakteknya mereka saling bertumpang tindih. Secara keseluruhan kami membutuhkan lima sampai delapan bulan untuk persiapan pembelajaran di setiap lokasi penelitian.

Kegiatan pertama dalam mempersiapkan pembelajaran para pemangku kepentingan adalah membangun kepercayaan dan hubungan baik dengan 
masyarakat lokal dan para pemangku kepentingan lainnya. Kami mulai melakukan hal ini sedini mungkin dengan cara melibatkan diri dalam berbagai kegiatan sehari-hari masyarakat. Selain itu, membangun hubungan dengan berbagai pihak juga terjadi pada saat melakukan dua kegiatan persiapan lainnya, yakni mengenali konteks dan mengidentifikasi pokok-pokok permasalahan. Sementara tim kami mengumpulkan data untuk mengenali konteks lokal dan berkegiatan untuk mengidentifikasi pokok-pokok permasalahan, terbangunlah keakraban dan rasa saling percaya antara tim dan berbagai pemangku kepentingan. Dalam hal ini staf CIFOR banyak terbantu oleh staf dari mitra-mitra LSM yang fasih berbahasa daerah setempat dan mengenal adat-istiadat lokal. Tim kami membutuhkan waktu empat sampai enam bulan untuk mengembangkan hubungan baik dengan para pemangku kepentingan dan untuk mengembangkan komunikasi yang efektif dengan mereka.

Kegiatan kedua adalah mengenali konteks lokal. Pertama, kami perlu mengembangkan pengetahuan kami tentang para pemangku kepentingan di wilayah tersebut, pola hubungan di antara mereka, dan kepentingan mereka masing-masing berkaitan dengan hutan. Walaupun kajian yang dilakukan sebelumnya untuk memilih lokasi telah menyediakan informasi tentang keadaan di lokasi, kami perlu mengumpulkan data yang lebih rinci dan secara spesifik

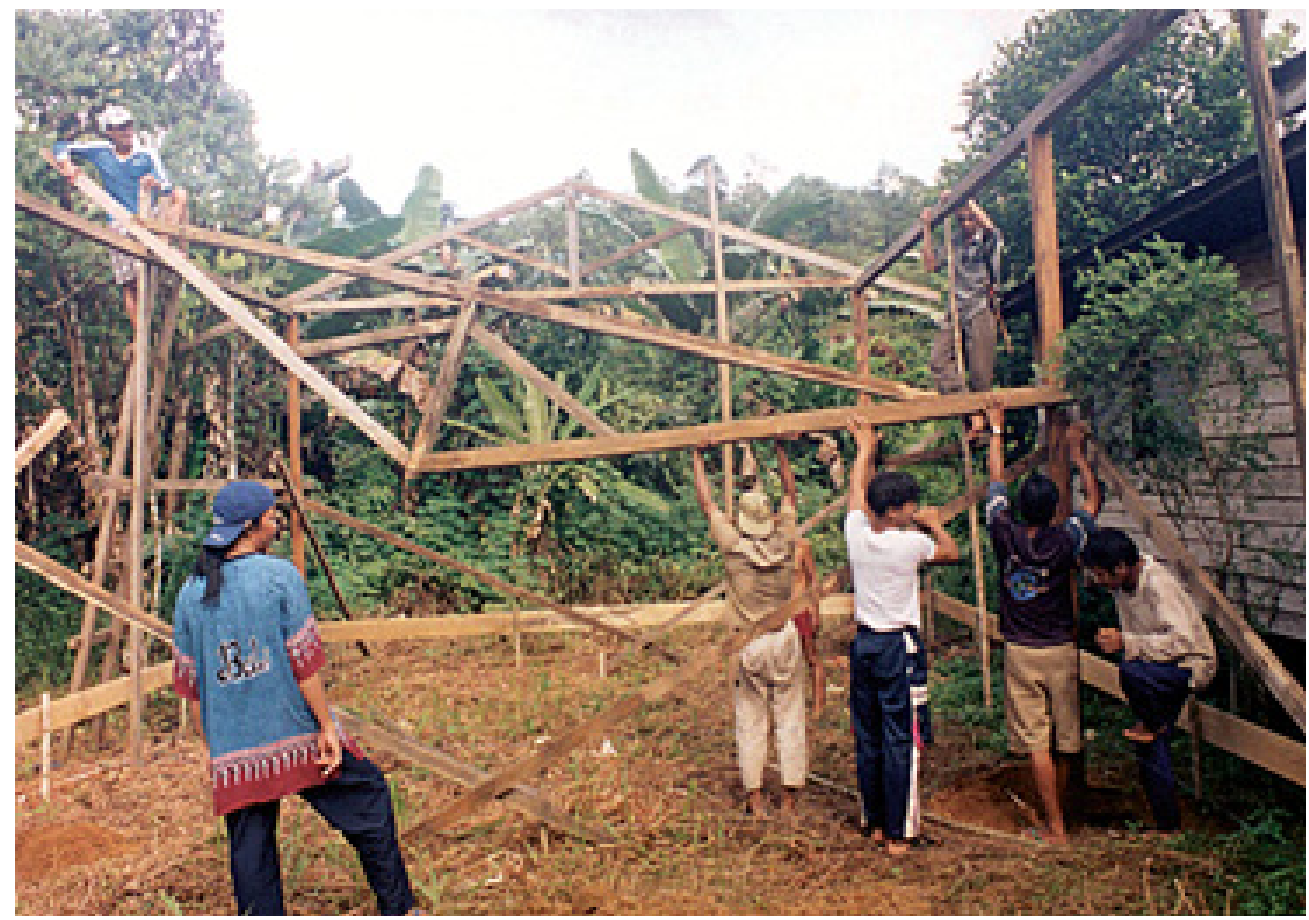

Menjadi bagian dari kegiatan sehari-hari masyarakat merupakan cara yang penting untuk membangun hubungan baik dan mengenali konteks lokal. 
diarahkan untuk penerapan ACM. Untuk itu, kami menggunakan berbagai pendekatan dan alat bantu guna mengidentifikasi dan menganalisis para pemangku kepentingan (lihat Lampiran 1 dan Lampiran 2).

Selain pengetahuan tentang para pemangku kepentingan, kami juga mengembangkan pengetahuan dasar tentang konteks pembelajaran para pemangku kepentingan. Dasar informasi yang kami kembangkan meliputi informasi biofisik, sosial-ekonomi, kebijakan, dan aspek kelembagaan lokal. Dalam melakukan hal ini, kami menggunakan beranekaragam metode pengumpulan data secara partisipatif dan juga beberapa metode yang lebih "konvensional". Lampiran 1 menyajikan berbagai acuan guna melakukan kajian konteks lokal, sedangkan Lampiran 2 menguraikan berbagai alat bantu yang dapat digunakan dalam melakukannya.

Terakhir, bersama para pemangku kepentingan, kami menjajaki kebutuhan pembelajaran mereka dengan cara mengidentifikasi pokok-pokok permasalahan yang ingin mereka tangani bersama serta merumuskan pertanyaan-pertanyaan yang mereka ingin cari jawabannya melalui pembelajaran. Dari kajian konteks lokal yang kami lakukan, kami telah mempunyai informasi dasar tentang pokokpokok permasalahan yang dihadapi para pemangku kepentingan, tetapi pada tahap ini adalah penting jika pengidentifikasian pokok permasalahan dilakukan oleh mereka sendiri.

Kami menyadari bahwa mengidentifikasi pokok-pokok permasalahan merupakan tahap yang penting dan menentukan untuk proses selanjutnya, dan karenanya patut diberi waktu dan perhatian yang memadai. Seperti telah kami catat sebelumnya, kegiatan ini penting juga dalam penerapan ACM yang tidak melibatkan "orang luar", melainkan hanya para pemangku kepentingan lokal saja.

Dalam waktu yang tidak terlalu lama kami temukan bahwa di kedua lokasi penelitian permasalahan yang mendesak cenderung berkisar di sekitar berkurangnya ketersediaan sumber daya hutan. Hal tersebut mempengaruhi penghidupan masyarakat secara negatif.

Memprioritaskan pokok-pokok permasalahan yang ada bersama para pemangku kepentingan ternyata bukanlah suatu hal yang mudah. Hal ini karena berbagai kelompok sosial dan perseorangan memiliki pandangan yang saling berbeda tentang bagaimana meningkatkan penghidupan mereka (Gambar 10). Kami menyadari bahwa keadaan nyata cukup kompleks. Hubungan sosial antara para pemangku kepentingan membentuk suatu pola hubungan yang saling berkaitan dan rumit. Dalam situasi seperti ini tingkah laku dan tindakan pemangku kepentingan yang satu berpengaruh terhadap penghidupan pemangku kepentingan lainnya, dan sebaliknya. 


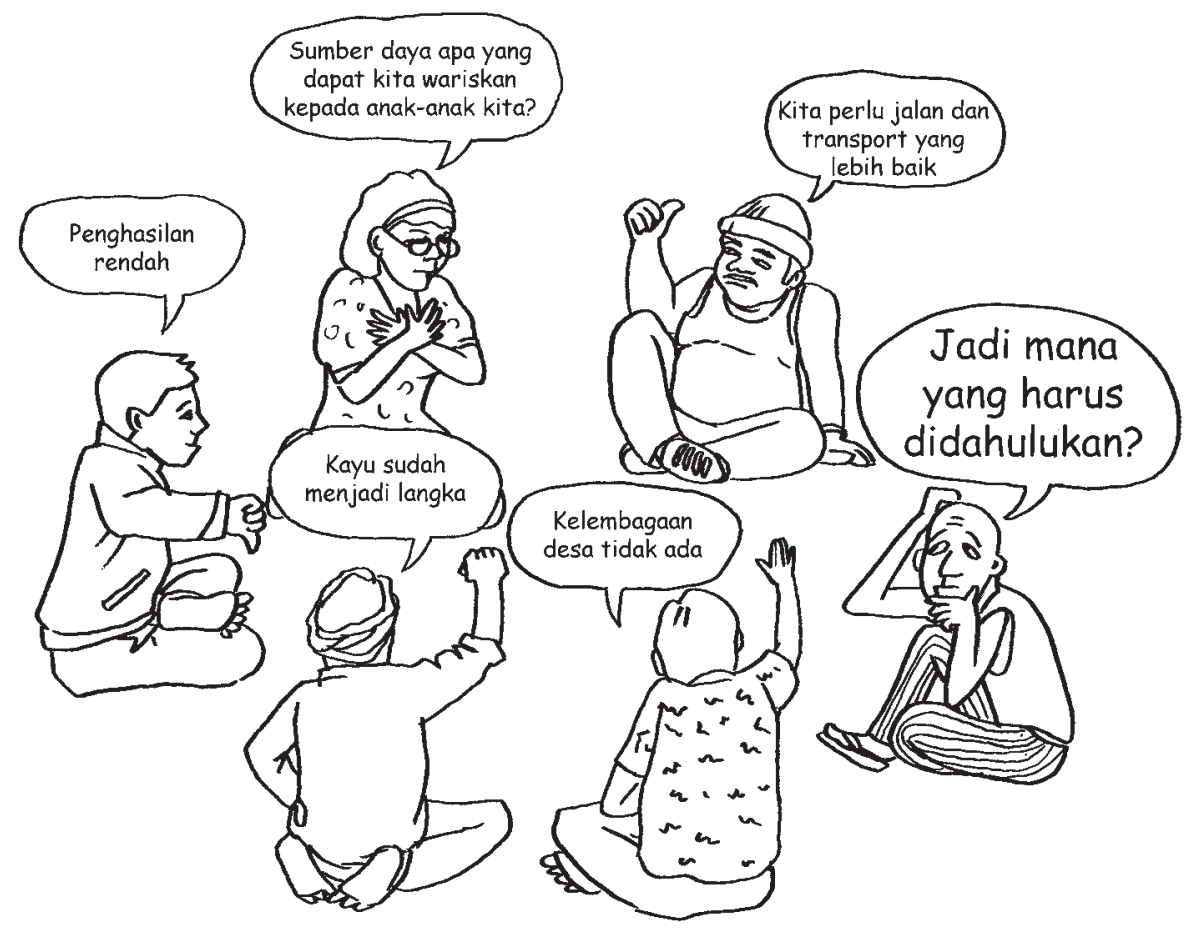

Gambar 10. Dari identifikasi pokok-pokok permasalahan ke penentuan prioritas merupakan langkah BESAR

Bersama para pemangku kepentingan, kami melakukan pengkajian terhadap berbagai masalah penghidupan yang mereka hadapi. Masalah-masalah itu sangat berbeda untuk masing-masing pemangku kepentingan. Tim kami membutuhkan waktu sekitar enam bulan untuk mendampingi para pemangku kepentingan di kedua lokasi memprioritaskan pokok-pokok permasalahan yang telah diidentifikasi. Proses ini membutuhkan waktu yang tidak sedikit karena masingmasing pemangku kepentingan melihat penting atau tidaknya suatu masalah berdasarkan persepsi dan penilaian mereka masing-masing. Sering mereka bahkan tidak menyadari bahwa pihak lain melihat dan menilai sesuatu dengan cara yang berbeda.

Kami sering menemukan, ketika para pemangku kepentingan menghadapi masalah yang sama, masing-masing merumuskannya dengan cara yang berbeda dan bahkan bisa saja memikirkan pemecahan masalah yang berbeda pula (Kotak 15). Hal ini terjadi karena setiap pemangku kepentingan melihat suatu masalah melalui "saringan" pengalaman dan latar belakang sejarah dan dengan tujuan masa depan masing-masing. Kotak 16 menunjukkan bagaimana para pemangku kepentingan dengan pendampingan tim kami mengidentifikasi pokok-pokok pembelajaran mereka. 
Kotak 15. Persepsi yang berbeda tentang permasalahan yang sama dengan pemecahan yang berbeda pula: Sebuah contoh dari Jambi

Sekelompok Orang Rimba yang berada di hutan Desa Baru Pelepat melihat diserangnya tanaman pangan dan karet oleh hama babi sebagai masalah yang berasal dari luar (faktor eksternal). Babi-babi tersebut datang dari lokasi yang sumber daya hutannya sudah menurun sehingga mereka terdorong untuk mencari habitat baru. Dengan sudut-pandang lain, sekelompok penduduk desa yang kami ajak membicarakan permasalahan ini, cenderung melihat hama tersebut sebagai akibat dari pembukaan lahan untuk perladangan oleh masyarakat secara tersebar, bukannya berdekatan dalam satu hamparan (faktor internal). Mereka berpikir bahwa jika mereka membuka ladang secara berkelompok di tempat yang berdekatan, seperti pernah mereka lakukan di masa lalu, kemungkinan dirambahnya ladangladang mereka oleh babi akan lebih kecil.

Kelompok Orang Rimba disebut tadi percaya bahwa jalan keluar dari masalah ini adalah memburu babi-babi tersebut. Sementara penduduk desa disebut di atas cenderung melihat perladangan secara berkelompok, bukan terpisah, sebagai pemecahannya. Ini adalah suatu contoh bagaimana terhadap masalah yang sama, masing-masing pemangku kepentingan melihat persoalan dan solusi dari sudut pandang yang berbeda.

Kotak 16. Proses mengidentifikasi pokok-pokok pembelajaran

Untuk mengidentifikasi pokok-pokok pembelajaran, kami memfasilitasi pertemuan bersama antara para pemangku kepentingan dari lima dusun di Desa Baru Pelepat. Proses seperti ini juga dilakukan di Pasir. Dengan menggunakan diskusi kelompok terfokus (focus group discussion), kami mendiskusikan dengan para peserta pertemuan masalah-masalah penghidupan yang menurut mereka perlu diatasi. Beberapa kelompok, seperti kaum perempuan, tidak terbiasa untuk berbicara dalam suatu pertemuan umum. Oleh karena itu, kami memberikan kesempatan terlebih dahulu kepada mereka untuk berbagi pendapat dalam diskusi kelompok kecil yang dirasakan lebih nyaman dibandingkan pertemuan besar. Pokok-pokok masalah yang teridentifikasi dalam pertemuan-pertemuan kecil ini kemudian dikomunikasikan kepada kelompok-kelompok lainnya dalam pertemuan tingkat dusun. Pertemuan semacam ini biasanya dilakukan pada hari Jumat siang setelah kaum laki-laki kembali dari hutan yang menjadi tempat bekerja mereka sebagai pembalak hutan selama 3 sampai 5 hari seminggu.

Pertemuan-pertemuan di atas dilengkapi pula dengan berbagai pertemuan informal di tingkat desa. Pertemuan-pertemuan ini membantu kami dalam mengembangkan pemahaman tentang aspirasi para pemangku kepentingan maupun kondisi penghidupan yang ingin mereka rubah dan tingkatkan. 


\section{Mengorganisasikan pembelajaran}

Tujuan kegiatan ini adalah untuk meletakkan landasan struktural yang dapat membantu kami mengorganisasikan pembelajaran bagi para pemangku kepentingan. Sambil bergiat bersama para pemangku kepentingan di kedua lokasi, kami mencoba memahami kondisi semacam apa yang dapat mendorong terjadinya pembelajaran bersama, baik dari lingkungan sosial maupun lingkungan alam mereka. Dengan kata lain, kami bertanya pada diri kami, prinsip-prinsip dasar apakah yang bisa kami gunakan sebagai acuan dalam mengorganisasikan pembelajaran agar terbentuk kondisi yang memicu pembelajaran bersama. Seiring dengan berjalannya kegiatan di lapangan, kami mengamati bahwa ada empat prinsip yang menjadi pokok, yakni:

- Para pemangku kepentingan harus merasa memiliki pembelajaran yang terjadi

- Semua pemangku kepentingan harus terwakili dalam kegiatan pembelajaran

- Pembelajaran harus berdasarkan pengalaman

- Pembelajaran harus terjadi melalui komunikasi.

Langkah selanjutnya adalah merancang suatu aransemen organisasi (tata organisasi) sebagai "ruang" untuk menciptakan kondisi pembelajaran yang bertumpu pada keempat prinsip di atas. Kami menyebut aransemen organisasi semacam ini sebagai platform ${ }^{12}$ untuk mengorganisasikan pembelajaran (Kotak 17). Contoh-contoh platform pengorganisasian pembelajaran semacam ini dari lokasi penelitian adalah kegiatan simpan-pinjam kelompok kaum perempuan di Jambi, lokakarya tingkat kecamatan untuk memprioritaskan pokok-pokok pembelajaran di Pasir, dan pertemuan negosiasi antardesa tentang batas-batas desa.

Kotak 17. Platform untuk mengorganisasikan pembelajaran

Suatu platform adalah tata pengorganisasian yang memenuhi persyaratan untuk terjadinya pembelajaran antara para pemangku kepentingan terpenuhi. Platform semacam ini dapat membantu kita dalam menyelenggarakan kegiatan yang mendorong pembelajaran bersama dan bertumpu pada empat prinsip berikut:

- Pembelajaran dimiliki oleh semua pemangku kepentingan

- Keterwakilan semua pemangku kepentingan

- Pembelajaran melalui pengalaman

- Pembelajaran melalui komunikasi.

\section{Prinsip 1: Kepemilikan proses pembelajaran}

Dari pengalaman kami sebelumnya dalam bergiat bersama masyarakat lokal di tempat lain, kami yakin mengenai satu prinsip: untuk terjadinya pembelajaran 
secara efektif, maka pembelajaran harus menjadi milik semua pihak yang terlibat dalam proses. Namun, yang merupakan tantangan sekarang ini, adalah keragaman dari mereka yang harus kami dampingi pembelajarannya. Setiap pemangku kepentingan mempunyai cara pandang sendiri tentang bagaimana mengelola sumber daya alam. Jika proses pembelajaran harus menjadi milik semua pemangku kepentingan yang terlibat di dalamnya, kegiatan pembelajaran bukan saja harus membantu mereka masing-masing dalam mengembangkan pengetahuannya, tetapi juga semua pihak sebagai satu kelompok untuk mencapai tujuan pembelajaran kolektif.

Jadi, dalam mengorganisasikan pembelajaran penting untuk tidak hanya terfokus pada pembelajaran yang bermakna bagi para pemangku kepentingan secara perseorangan (kepemilikan individual), tetapi juga bagi semua pemangku kepentingan sebagai sebuah kelompok (kepemilikan kolektif). Meskipun begitu, tim kami makin menyadari bahwa ketika suatu kelompok pemangku kepentingan belajar bersama, perhatian yang cukup tetap harus diberikan terhadap pembelajaran setiap pemangku kepentingan secara individual. Dengan kata lain, ketika berbicara tentang pembelajaran multipihak, kita bukan saja berhadapan dengan proses kolektif, tetapi pada saat yang sama juga dengan pembelajaran dari masing-masing pemangku kepentingan. Karenanya, pembelajaran multipihak harus mendorong kedua-duanya secara berimbang: baik pembelajaran para pemangku kepentingan secara individual maupun sebagai kelompok.

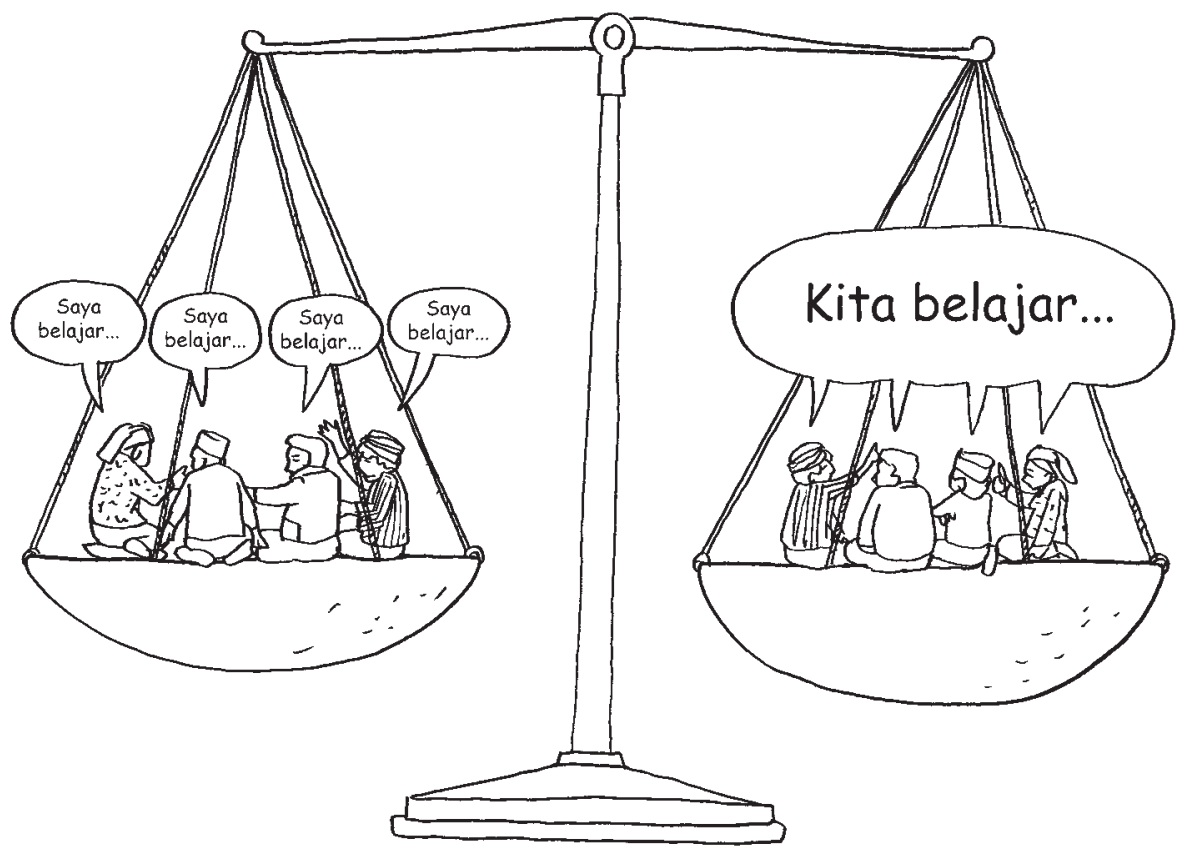

Gambar 11. Menyeimbangkan kepemilikan individual dan kepemilikan kolektif atas pembelajaran 
Suatu contoh kebutuhan pembelajaran individual adalah kasus seorang tokoh adat di Jambi. Karena kepentingannya sendiri, pada awal kegiatan lapangan tokoh ini sering sulit menerima pandangan orang lain. Dia perlu belajar untuk lebih memahami pihak lain dan menghargai pandangan orang yang berstatus sosial lebih rendah daripada dirinya. Berdasarkan kebutuhan belajar individual ini, tim kami memberi perhatian khusus terhadap kebutuhan belajar orang tersebut. Kami berusaha untuk membantu tokoh tersebut mengembangkan pengetahuan dan kesadaran tentang konsep kepemimpinan dan tentang perlunya mendengarkan orang lain jika ia menginginkan orang lain melihatnya sebagai seorang pemimpin.

Sebagai contoh kebutuhan kolektif dapat diberikan kebutuhan dari baik masyarakat Rantau Buta dan Rantau Layung maupun dinas kehutanan akan kejelasan batas desa dengan Hutan Lindung Gunung Lumut.

\section{Apa arti Prinsip 1 untuk kegiatan lapangan?}

Untuk mewujudkan baik kepemilikan individual maupun kepemilikan kolektif, kami melihat bahwa kegiatan pembelajaran harus terpusat pada pokok-pokok permasalahan yang menjadi perhatian masing-masing pemangku kepentingan dan pada saat yang sama relevan untuk mereka semua sebagai suatu kelompok. Persoalan bagaimana memprioritaskan pokok-pokok permasalahan oleh keseluruhan kelompok menjadi sangat penting, bahkan mutlak diperlukan. Masing-masing pemangku kepentingan harus mengembangkan pemahaman tentang pandangan pemangku kepentingan lainnya, dan kemudian masalahnya harus dibingkai kembali (reframe) dalam suatu perspektif bersama. Dengan kata lain, para pemangku kepentingan harus dapat memasukkan berbagai sudut pandang tentang masalah tersebut dalam satu bingkai bersama. Kotak 18 menggambarkan

Kotak 18. Membingkai kembali (reframe) beragam sudut pandang

Salah satu masalah yang mempengaruhi penghidupan masyarakat di lokasi Jambi adalah bahwa para pendatang merasa diperlakukan tidak adil karena tidak diikutsertakan dalam pengambilan keputusan masyarakat tentang sumber daya alam. Para tokoh adat dan penduduk asli, kelompok Minangkabau, adalah pihak yang "berkuasa" dan biasanya merekalah yang mengambil keputusan-keputusan penting tentang sumber daya alam desa.

Menurut sudut pandang penduduk asli, karena mereka yang paling lama tinggal di Baru Pelepat, wajarlah jika mereka yang paling berwenang dan berhak atas "posisi khusus" mereka itu. Dari sudut pandang mereka, masalahnya bukan terutama rendahnya partisipasi kaum pendatang, melainkan tidak pahamnya kaum pendatang akan posisi dan wewenang kelompok Minangkabau. 
Untuk terjadinya pembelajaran yang bermakna bagi kedua kelompok pemangku kepentingan ini, kami mengembangkan kegiatan belajar yang berkenaan dengan persoalan perwakilan masyarakat. Dalam kegiatan itu perspektif keduanya diperlakukan sama penting. Kegiatan-kegiatan ini memungkinkan pihak pendatang untuk mulai belajar mengapa kelompok Minang dan para pemimpin adat memperlakukan mereka dengan cara berbeda. Demikian pula, kegiatan itu terfokus pada kebutuhan belajar kelompok Minang dan para pemimpin adat untuk memahami mengapa kaum pendatang merasa bahwa mereka ingin menyuarakan pendapat mereka.

Dengan menyelenggarakan kegiatan belajar yang mendorong kedua kelompok yang berbeda itu untuk saling memahami perspektif pihak lainnya dan untuk menilai secara kritis pemikiran mereka sendiri, terciptalah sebuah ruang untuk pertukaran pandangan yang positif dan penelaahan pandangan lama secara bersama.

Kotak 19. Pokok-pokok pembelajaran yang diprioritaskan

\section{Pokok-pokok pembelajaran Jambi}

1. Bagaimana wilayah adat masyarakat dapat diakui oleh desa tetangga dan pemerintah?

2. Bagaimana meningkatkan kapasitas pengorganisasian dan kelembagaan masyarakat dalam hal pengelolaan sumber daya alam? Bagaimana meningkatkan keterwakilan para pemangku kepentingan masyarakat, termasuk kelompok perempuan? Bagaimana meningkatkan kolaborasi antara para pemangku adat dan pemerintah desa?

3. Strategi apa yang bisa dikembangkan untuk meningkatkan penghidupan masyarakat?

\section{Pokok-pokok pembelajaran Pasir}

1. Bagaimana wilayah adat masyarakat dapat diakui oleh desa tetangga, pemerintah, dan perusahaan pemilik $\mathrm{HPH}$ ?

2. Bagaimana meningkatkan kapasitas kelembagaan masyarakat?

3. Apa saja alternatif pemanfaatan hasil hutan yang bisa dikembangkan untuk meningkatkan penghidupan masyarakat? Apakah peningkatan akses ke pasar rotan merupakan pilihan yang mungkin? Apakah pemanfaatan lahan bekas perladangan merupakan alternatif untuk meningkatkan penghidupan? 
sebuah contoh tentang bagaimana kami mengorganisasikan pembelajaran di Jambi agar para pemangku kepentingan dapat membingkai kembali perspektif yang ada. Kotak 19 menunjukkan pokok-pokok permasalahan yang kemudian diprioritaskan.

Prinsip 2: Keterwakilan semua pemangku kepentingan dalam pembelajaran Sejalan dengan perkembangan kegiatan lapangan, kami semakin menyadari bahwa semua pihak yang bisa mempengaruhi atau dipengaruhi oleh tindakantindakan dalam sistem sosial dan alam yang bersangkutan harus terlibat dalam kegiatan belajar. Jika pembelajaran tidak melibatkan mereka semua, kecil kemungkinannya, persoalan-persoalan pengelolaan sistem tersebut bisa ditangani secara efektif karena pembelajaran tidak akan mencakup seluruh sistem.

Namun karena para pemangku kepentingan jumlahnya cukup banyak, tidaklah mungkin bagi kami untuk melibatkan mereka semua secara langsung. Kami hanya bisa menyelenggarakan pembelajaran untuk wakil-wakil mereka saja. Walaupun begitu, kami perlu memastikan bahwa semua pemangku kepentingan akan merasa memiliki pembelajaran itu. Dengan kata lain, menyelenggarakan pembelajaran bagi para wakil berarti bahwa sebuah mekanisme diperlukan untuk memastikan semua hasil pembelajaran dapat sampai juga kepada semua anggota masing-masing kelompok.

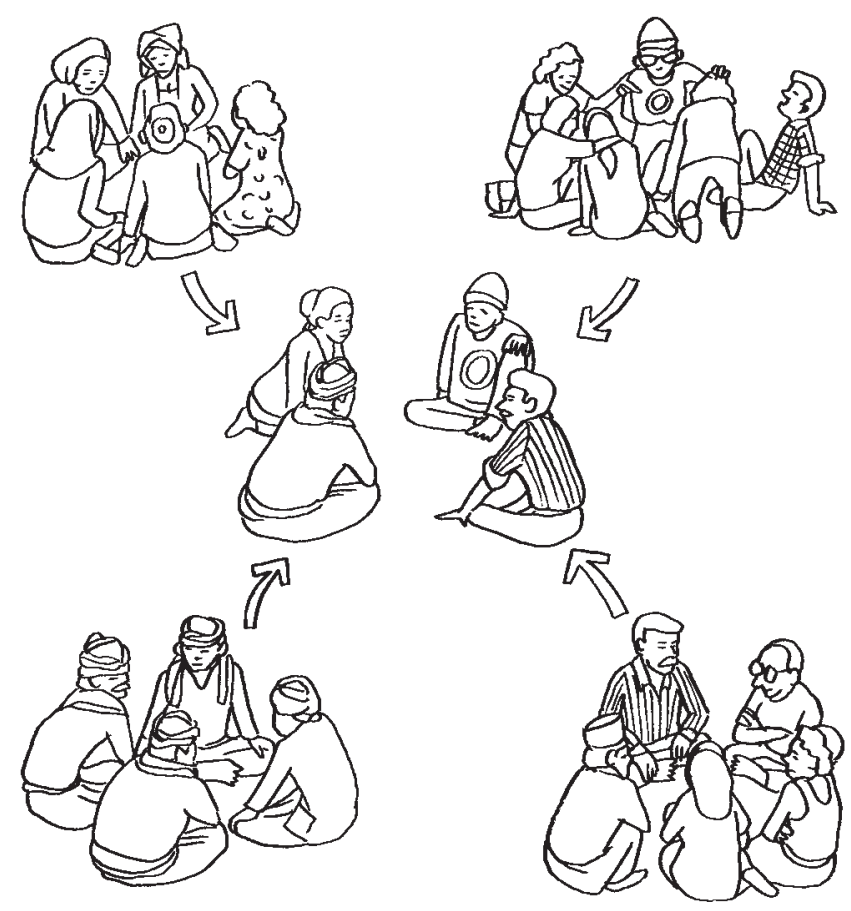

Gambar 12. Dari banyak orang, sekelompok orang saja yang dipilih sebagai wakil untuk berpartisipasi 
Prinsip tentang keterwakilan mungkin merupakan hal terpenting untuk mengembangkan platform-platform pembelajaran. Jika kita mengabaikan prinsip ini bisa saja pembelajaran tidak akan menghasilkan perubahan yang bermakna dalam sistem karena adanya pihak-pihak yang aktif di dalamnya, tetapi tidak dilibatkan.

\section{Apa arti Prinsip 2 untuk kegiatan lapangan?}

Kami harus memastikan agar kegiatan lapangan menjangkau semua pemangku kepentingan, namun sementara tetap dapat dikelola dengan baik. Salah satu cara untuk melakukan hal ini adalah dengan menyelenggarakan kegiatan berdasarkan teori yang disebut "platform berjenjang" (nested platforms). ${ }^{13}$ Teori tersebut mengatakan bahwa platform yang lebih kecil terlingkupi oleh platform yang lebih luas dan keduanya saling mempengaruhi karena merupakan bagian dari satu sistem.

Ketika memulai kegiatan lapangan, kami tidak menyadari adanya teori semacam itu, tetapi baru belakangan kami menyadari bahwa apa yang kami lakukan ternyata cukup sesuai dengan kerangka teoretis ini. Di kedua lokasi kajian, pengorganisasian pembelajaran dengan platform berjenjang dapat digambarkan seperti pada Gambar 13.

JAMBI

- Masyarakat Baru Pelepat
- Masyarakat desa
tetangga

- Perwakilan para pemangku kepentingan Baru Pelepat berikut:

- Orang Rimba

- Penduduk asli

- Pendatang

- Elit desa

- Generasi muda

- Lembaga adat

- Pemerintah desa

- Organisasi perempuan

- Perwakilan masyarakat desa tetangga

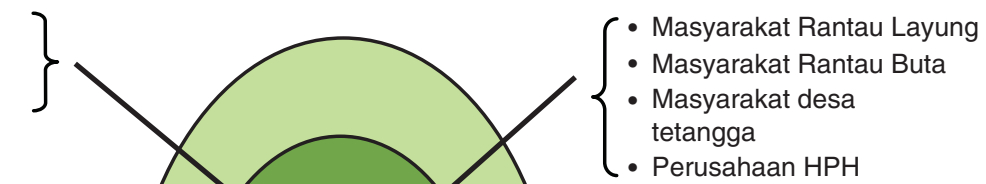

PASIR

- Perusahaan HPH

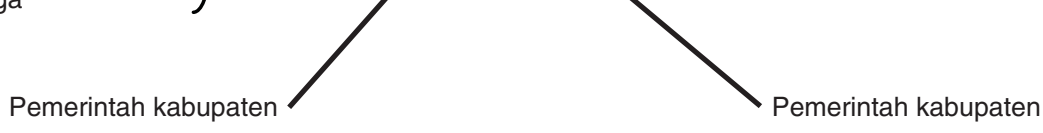

Gambar 13. Menyelenggarakan pembelajaran bersama bagi para pemangku kepentingan dalam platform berjenjang (nested platforms) 
Gambar ini menunjukkan bahwa keputusan yang dibuat oleh pemerintah tingkat kabupaten atau pada lapisan luar (yang misalnya terjadi pada kebijakan yang mengatur pemanfaatan hasil hutan) mempengaruhi tindakan pada tingkat masyarakat (lapisan tengah di gambar). Di sisi lain, tindakan masyarakat mempengaruhi pengambilan keputusan di tingkat kabupaten. Sebagai contoh, pengambilan hasil hutan secara berlebihan oleh masyarakat dapat mendorong pengambil keputusan pemerintah kabupaten untuk menerapkan pengawasan yang lebih ketat. Jadi, interaksi antara kedua lapisan ini terjadi melalui umpan balik dua arah.

Tim kami aktif di dua tingkat:

- Lapisan paling dalam (pusat lingkaran): untuk menyelenggarakan kegiatan belajar bagi wakil-wakil para pemangku kepentingan, masyarakat, dan dalam kasus di Pasir para pemangku kepentingan masyarakat dan perusahaan HPH

- Lintas kabupaten (lapisan luar) dan pemangku-pemangku kepentingan (pusat lingkaran): untuk menyelenggarakan kegiatan bagi wakil masyarakat lokal, pengusaha hasil hutan, dan pengambil keputusan tingkat kabupaten.

Ada dua implikasi lain dari prinsip ini, yakni bagaimana memilih wakil-wakil para pemangku kepentingan dan bagaimana memastikan terbangunnya mekanisme agar pembelajaran menjangkau semua pemangku kepentingan. Lampiran 1 (Kegiatan 2, Langkah 2) memberi beberapa acuan bagaimana kedua hal tersebut dapat dipraktekkan.

\section{Prinsip 3: Belajar dari pengalaman}

Melalui suatu kajian pustaka, kami melihat bahwa untuk terjadinya pembelajaran yang efektif, pembelajaran itu harus tertata sedemikian rupa sehingga menciptakan peluang bagi para pemangku kepentingan untuk membentuk pengetahuan baru dari pengalamannya. Pembelajaran seperti itu sering disebut "pembelajaran berdasarkan pengalaman" (experiential learning) ${ }^{14}$. Pembelajaran semacam ini dibangun dari pandangan bahwa manusia itu sendiri adalah sumber informasi yang paling kaya untuk mengembangkan pengetahuan.

Beberapa pakar teori dan praktisi pembelajaran menegaskan bahwa manusia, terutama orang dewasa, daripada ditunjukkan atau diberitahukan hal-hal apa yang harus dia pelajari, akan mengembangkan pengetahuan secara lebih efektif jika mereka sendirilah yang menentukan hal-hal apa yang harus dipelajarinya. ${ }^{15}$ Mengadakan kegiatan pembelajaran bagi para pemangku kepentingan dengan cara membangun pengalaman dapat memicu mereka untuk melalui suatu proses penemuan hal-hal baru (discovery) dan proses pengembangan pengetahuan. 


\section{Apa arti prinsip 3 untuk kegiatan lapangan?}

Seperti disebut di Bab 1, kami mengadopsi penelitian aksi partisipatif (PAR) sebagai metodologi guna mendorong para pemangku kepentingan agar dapat meningkatkan kondisi lingkungan alam dan lingkungan sosial mereka. Metodologi PAR yang kami pakai, kami sesuaikan dengan proses berulangulang (iteratif) yang dilakukan secara bersama oleh para pemangku kepentingan dengan tahapan-tahapan pengamatan, perencanaan, aksi, pemantauan, dan refleksi, yakni ciri khas dari pendekatan ACM (lihat Bab 2, hlm. 20). Proses semacam ini memungkinkan dilakukannya perbaikan pengelolaan sesering dibutuhkan secara kolaboratif. Berdasarkan pengamatan, kami melihat bahwa metodologi ini sangat efektif untuk mewujudkan konsep pembelajaran berdasarkan pengalaman yang kami maksud di atas.

Menurut kami ada dua alasan untuk hal ini:

- Penelitian aksi partisipatif menawarkan sebuah kerangka yang dapat memandu tim kami dan para pemangku kepentingan untuk memberi struktur pada proses pembelajarannya sehingga menjadi lebih sistematis. Oleh karena dilakukan secara berulang-ulang, terbukti dapat menjadi dasar kuat untuk membangun pengalaman.

- Kita telah melihat di atas bahwa belajar berdasarkan pengalaman secara teoretis sangat penting dalam mengembangkan pengetahuan. Walaupun begitu, kita harus tetap waspada karena tidak akan selalu dapat dikatakan bahwa dari sebuah pengalaman baru terbentuklah pengetahuan baru, ataupun terdoronglah kita untuk menanggalkan pandangan-pandangan lama. Kenapa demikian? Asumsi-asumsi kita sesungguhnya lebih tidak tergoyahkan daripada yang kita sadari sendiri. Sebagaimana terbukti dari kegiatan lapangan kami, PAR dapat membuat pembelajaran lebih reflektif sehingga menjadi dasar yang kuat untuk terbentuknya pengetahuan baru. Dengan kata lain, pengalaman yang dibangun melalui PAR menjadi dasar untuk pembelajaran dalam artian yang sesungguhnya.

Dengan menggunakan PAR sebagai panduan, kami mendampingi para pemangku kepentingan dalam menangani pokok-pokok pembelajaran yang telah mereka prioritaskan. Sebelum melanjutkan pembahasan, ada baiknya kita melihat kembali proses-proses berulang-ulang di dalam PAR dan yang menjadi ciri khas ACM. Seperti dapat dilihat pada Gambar 14, proses-proses belajar untuk mengatasi pokok-pokok permasalahan terjadi sepanjang waktu, dari saat ini hingga masa depan. Proses ini melalui tahapan-tahapan pengamatan, perencanaan, aksi, dan refleksi yang berulang-ulang. Perhatikan bahwa dalam proses yang berlangsung di lapangan, pemantauan tidak berdiri sendiri sebagaimana berlaku sesuai dengan teori dan yang dibahas pada Bab 2. 


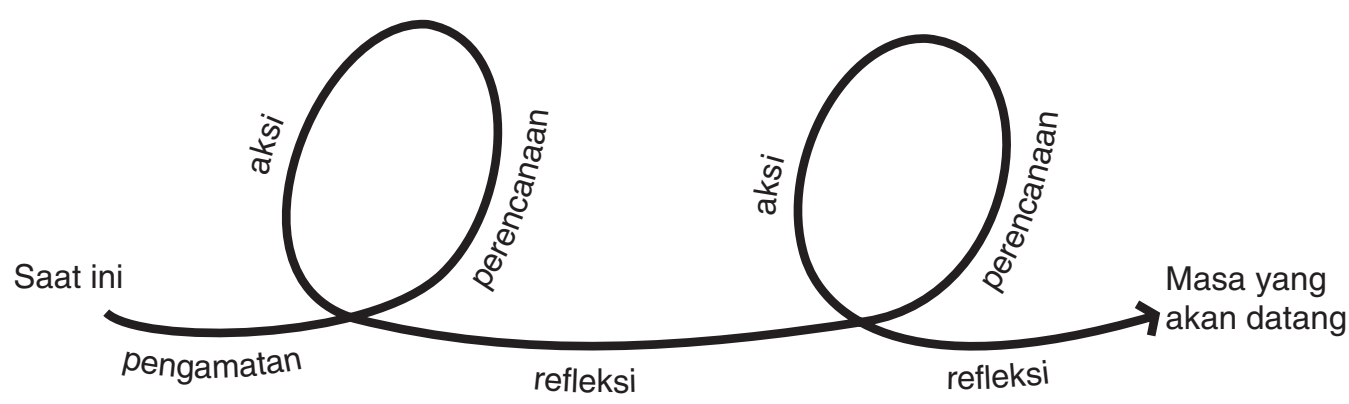

Gambar 14. Berbagai proses pembelajaran yang digunakan dalam memecahkan pokok permasalahan lokal

Proses ini pada dasarnya merupakan kegiatan pembelajaran yang kami selenggarakan untuk para pemangku kepentingan dalam menangani pokokpokok permasalahan yang telah mereka identifikasi (lihat Kotak 19). Di dalam buku ini, hendak kami bagi proses pembelajaran para pemangku kepentingan dalam menangani tiga pokok permasalahan: penyelesaian masalah tata batas, peningkatan kapasitas pemerintahan desa, dan peningkatan penghidupan melalui pemanfaatan lahan bekas perladangan. Dua pokok pembelajaran pertama dijelaskan dalam Kotak 20 dan Kotak 21, sedangkan pokok pembelajaran ketiga dapat dilihat di Lampiran 1. Lihat juga Gambar 15 dan Gambar 16.

Kotak 20. Bersama-sama memetakan tata batas: Sebuah contoh pembelajaran berdasarkan pengalaman

Pengamatan. Salah satu masalah utama yang dihadapi masyarakat Rantau Buta dan Rantau Layung di Pasir berkenaan dengan batas antara Hutan Lindung Gunung Lumut dan desa-desa mereka. Masyarakat menolak batas hutan karena beberapa alasan. Salah satu garis batas melintasi wilayah adat mereka. Garis lainnya ada yang terlalu dekat dengan batas desa, sementara ada juga yang cukup jauh dari batas desa. Hal tersebut menimbulkan kebingungan warga desa tentang garis batas mana yang benar. Tidak pernah masyarakat diajak berdiskusi atau dimintai pendapatnya sewaktu penentuan batas ini; bahkan tidak ada pemberitahuan kepada kepala desa. Tim kami menyarankan agar masyarakat menyampaikan persoalan ini kepada pemerintah kabupaten. 
Karena tim kami berjanji untuk mendampingi masyarakat dalam pertemuan dengan pemerintah kabupaten, mereka merasa cukup percaya diri untuk bertemu dengan pemerintah. Selama ini mereka jarang saling berinteraksi. Kesempatan ini adalah kali pertama mereka akan berinteraksi dengan pemerintah, yakni untuk menyampaikan ketidaksetujuan mereka. Walaupun tidak dapat menduga bagaimana pemerintah akan menanggapinya, masyarakat sangat bersemangat untuk bertemu dengan para pembuat kebijakan.

Dalam lokakarya yang kami selenggarakan, semua pihak, termasuk pemerintah, sangat berminat untuk berupaya menyelesaikan persoalan tata batas ini. Mereka menyetujui bahwa penandaan tata batas harus dilakukan secara partisipatif.

Rencana 1. Pada saat lokakarya, peserta merencanakan untuk melakukan survei bersama. Mereka menyepakati bahwa cara terbaik untuk melakukan hal ini adalah, masyarakat melakukan survei dengan pendampingan dari tim kami. Setelah itu, data yang terkumpul akan dibandingkan dengan data yang ada di dinas kehutanan (Dishut) kabupaten.

Aksi1. Bersamatim kami, masyarakat menyelenggarakan survei dan mengumpulkan titik-titik koordinat garis batas hutan, mengambil foto patok-patok penanda batas dan rambu-rambu tata batas lainnya, serta informasi tentang tanah masyarakat yang terkena batas. Setelah titik-titik koordinat tersebut dimasukkan ke dalam peta wilayah, hasilnya disampaikan kepada Dishut untuk dibandingkan dengan datadata yang ada selama itu.

Refleksi 1. Setelah membandingkan data tentang kedua garis batas tersebut dalam suatu pertemuan bersama, Dishut mengakui bahwa garis yang letaknya paling jauh dari desa adalah batas yang benar dan bukannya garis yang dekat dengan desa. Perbedaan antara kedua garis itu disebabkan oleh kesalahan petugas lapangan Dishut. Ketika melakukan survei pemeliharaan batas, ia tidak dapat menemukan garis yang benar dan kemudian menempatkan garis dengan memperkirakan letaknya, yakni di lokasi yang sebenarnya terlalu dekat dengan desa.

Masyarakat merasa puas dengan penjelasan dari Dishut tersebut. Pada waktu itu juga mereka menyadari pentingnya batas desa yang jelas, antara lain untuk menghindari timbulnya konflik.

Rencana 2. Terdorong semangatnya untuk memetakan batas desa mereka, masyarakat Rantau Buta dan Rantau Layung membuat rencana bersama untuk mengundang Desa-Desa Kesunge, Sungai Terik dan Uko agar bergabung dalam 
kegiatan pemetaan tersebut. Mereka membayangkan bahwa pertemuan ini akan memberi kesempatan untuk membicarakan perbatasan wilayah desa berdasarkan aturan adat. Pertemuan ini akan ditindaklanjuti dengan survei lapangan guna mengumpulkan data untuk pemetaan.

Mereka kemudian berpikir bahwa mereka belum cukup terampil dalam hal pemetaan dan perlu dilatih terlebih dahulu. Oleh karena itu, mereka merencanakan untuk mendapatkan pelatihan tentang pemetaan.

Aksi 2. Masyarakat Rantau Buta dan Rantau Layung menghadiri pertemuan yang direncanakan, namun wakil-wakil desa-desa lainnya tidak datang. Meskipun begitu, masyarakat kedua desa tersebut berpandangan bahwa mereka dapat memulai kegiatan tersebut tanpa kehadiran wakil desa-desa lainnya. Mereka berharap, desa-desa lain itu akan tertarik kemudian kalau melihat bahwa mereka dapat memperoleh manfaat dari kegiatan ini, yakni keterampilan pemetaan batas desa yang jelas.

Pelatihan yang telah direncanakan kemudian dilakukan. Pelatihan ini termasuk bagaimana cara menggunakan peranti sistem penentuan posisi global (global positioning system (GPS)), pengolahan data, dan bagaimana menuangkan data ke dalam peta dasar.

Refleksi 2. Ketika direfleksikan, tidak ada masalah berarti yang muncul. Masyarakat percaya bahwa hal ini dikarenakan masyarakat kedua desa berasal dari sistem adat yang sama sehingga memiliki nilai-nilai yang sama. Hal ini memudahkan komunikasi.

Rencana 3. Masyarakat kedua desa membuat rencana untuk menyelenggarakan survei bersama.

Aksi 3. Didampingi tim kami, masyarakat kedua desa melaksanakan survei lapangan. Kelompok pelaksana survei terdiri atas para tokoh adat dan beberapa orang wakil dari kedua desa. Selama survei lapangan, mereka menemukan bahwa terdapat banyak tempat yang ternyata belum mereka ketahui sebelumnya. Peta dasar yang mereka bawa membantu mereka agar tidak tersesat. Selama survei ini tidak muncul masalah yang berarti sehingga dengan mudah mereka menyepakati titik-titik batas desanya.

Refleksi 3. Selama refleksi, wakil-wakil dari kedua desa saling memastikan bahwa mereka telah menyetujui batas yang telah disurvei. Masyarakat kedua desa tersebut menyadari bahwa batas desa yang jelas akan merupakan hal yang sangat penting di masa yang akan datang. 
Pengamatan. Beberapa waktu sebelumnya, masyarakat kedua desa mendengar bahwa ada dua perusahaan HPH yang telah masuk ke wilayah desa mereka. Kedua perusahaan tersebut beroperasi di dua desa yang berbeda: PT Majau beroperasi di Rantau Buta, sementara PT WMS di Kesunge. Tidak jelasnya batas antara kedua desa, telah menyebabkan konflik antara kedua perusahaan tersebut.

Rencana 4. Rantau Buta dan Rantau Layung membuat rencana untuk menindaklanjuti pemetaan batas desa. Menurut rencana itu, Kepala Desa Rantau Buta akan mengunjungi desa-desa tetangganya dan mengajak mereka untuk bersama-sama membuat peta perbatasan antara desa di wilayah tersebut. Tetapi, karena persoalan konflik antara kedua perusahaan HPH tersebut dirasakan jauh lebih mendesak, mereka memutuskan untuk menunda kegiatan bersama itu.

Rencana 3.1. Sebagai tindak lanjut dari pengamatan yang disebutkan di Refleksi 3, Kepala Desa Rantau Buta berencana untuk bertemu dengan para kepala desa desa-desa tetangga, khususnya Kesunge, untuk memberitahukan mereka tentang konflik yang terjadi antara kedua perusahaan HPH. Untuk penyelesaian masalah ini, penting bahwa semua desa di wilayah ini diberitahukan hal tersebut.

Aksi 3.1. Kepala Desa Rantau Buta bertemu dengan para kepala desa lainnya termasuk dari Kesunge. Wilayah yang dipersengketakan kedua perusahaan HPH terletak di kedua desa ini. Para kepala desa menindaklanjuti pertemuan ini dengan melakukan pendekatan kepada Dishut dan kedua perusahaan tersebut.

Refleksi 3.1. Semua pihak menyetujui bahwa kunjungan bersama untuk melihat letak garis batas antara kedua desa dan mengklarifikasi hal-hal yang tidak disepakati merupakan hal yang mendesak.

Rencana 3.2. Setelah refleksi, masyarakat kedua desa, kedua perusahaan HPH, dan Dishut berencana untuk bersama-sama melakukan survei lapangan. Biaya survei tersebut akan ditanggung oleh kedua perusahaan.

Aksi 3.2. Survei dilakukan bersama sesuai dengan rencana.

Refleksi 3.2. Surveilapangan mengungkapkan bahwa kedua perusahaan beroperasi di wilayah kedua desa, dan bukannya masing-masing perusahaan di salah satu dari kedua desa seperti yang mereka sangka sebelumnya. Pemetaan bersama telah menjelaskan hal ini. Setelah dirundingkan, semua pihak setuju bahwa kedua perusahaan itu akan memberi dana kompensasi kepada kedua desa. 
Kotak 21. Meningkatkan pemerintahan desa: Contoh lain pembelajaran berdasarkan pengalaman ${ }^{16}$

Untuk meningkatkan pemerintahan desa, para pemangku kepentingan di Baru Pelepat, Jambi, perlu mengembangkan kesadaran dan pemahaman tentang keterwakilan dalam pengambilan keputusan di desa mereka. Untuk memenuhi kebutuhan tersebut, para pemangku kepentingan masyarakat menempuh suatu proses pembelajaran dalam memilih wakil-wakil mereka yang akan menjadi anggota Badan Perwakilan Desa (BPD). Sifat politis dari proses tersebut, menuntut kami sebagai fasilitator untuk mendampingi para pemangku kepentingan dalam memaknai permainan politik yang terjadi dan mengembangkan pemahaman tentang perubahan-perubahan kondisi politik.

Berikut ini kami paparkan siklus pembelajaran yang terjadi dengan cara yang berbeda dari contoh sebelumnya. Pemaparan berikut memberi gambaran mengenai tiga "forum sosial" yang berperan dalam menciptakan pembelajaran antara para pemangku kepentingan. Forum-forum sosial ini masing-masing menjadi sebuah mekanisme untuk memantau proses-proses pembelajaran di antara mereka. Ketiga mekanisme ini adalah: pembentukan panitia pemilihan, pertemuan para pemangku kepentingan masyarakat, dan penyebarluasan informasi kepada seluruh masyarakat. Dalam siklus penelitian aksi partisipatif pada Gambar 16 kita bisa melihat siklus belajar yang mengikuti tahapan-tahapan pengamatan, perencanaan, aksi, dan refleksi.

Panitia pemilihan. Masyarakat memberi mandat kepada panitia pemilihan untuk bertindak atas nama masyarakat. Para anggota panitia berasal dari kelima dusun di Baru Pelepat dan keterwakilan ini menciptakan kondisi yang kondusif untuk keterlibatan seluruh anggota masyarakat.

Dengan pendampingan dari tim kami, panitia pemilihan melakukan beberapa tugas: mengembangkan prosedur pemilihan, mendata para pemilih yang memiliki hak suara, mencari dana pemilihan, serta mempersiapkan, melaksanakan, dan memantau pemilihannya. Dalam istilah penelitian aksi partisipatif, kegiatan yang dilaksanakan panitia pemilihan bisa dianggap sebagai kegiatan "pengamatan" dan "aksi" dalam siklus pengamatan—perencanaan—aksi-refleksi.

Pertemuan-pertemuan para pemangku kepentingan. Mekanisme kedua berupa pertemuan berkala antara para pemangku kepentingan yang diselenggarakan oleh panitia pemilihan. Para peserta dalam pertemuan-pertemuan ini merefleksikan aksi yang telah dilakukan, melaporkan perkembangan, mendiskusikan masalahmasalah yang muncul, meneruskan informasi yang berguna kepada atau dari masyarakat desa, dan membuat rencana bersama untuk menindaklanjuti aksi. 
Peran tim kami mendampingi panitia dalam memfasilitasi komunikasi antara para pemangku kepentingan dalam pertemuan. Kegiatan ini bisa dianggap sebagai tahap "refleksi" dan "perencanaan" dalam siklus penelitian aksi partisipatif.

Penyebarluasan informasi kepada masyarakat luas. Mekanisme ketiga adalah mekanisme komunikasi yang berkembang dengan sendirinya di antara warga desa, di luar fasilitasi kami. Dalam mekanisme ini, para anggota panitia pemilihan berperan sebagai informan kunci bagi warga desa lain yang mencari informasi. Oleh karena anggota panitia dipilih dari masing-masing dusun, arus informasi dapat menjangkau seluruh masyarakat desa. Sering, rumah tinggal para anggota panitia menjadi tempat pertemuan: di situ orang-orang secara spontan berkumpul untuk saling bertukar informasi tentang pemilihan. Warga desa secara spontan menyebarluaskan informasi yang berkenaan dengan pemilihan yang akan diselenggarakan. Proses-proses informal ternyata sangat penting dalam proses pembelajaran dan bukan hanya proses-proses pada pertemuan-pertemuan resmi yang sengaja diselenggarakan.

Suatu hal yang tidak kami duga sebelumnya adalah munculnya pemantauan masyarakat terhadap proses politik secara alami seiring dengan persiapan pemilihan. Orang-orang mulai secara aktif "mencari informasi" melalui interaksi mereka satu sama lainnya, menilai situasi yang berkembang berdasarkan "informasi yang dikumpulkan", mengorganisasi diri, dan berstrategi dalam rangka pemilihan anggota BPD. 


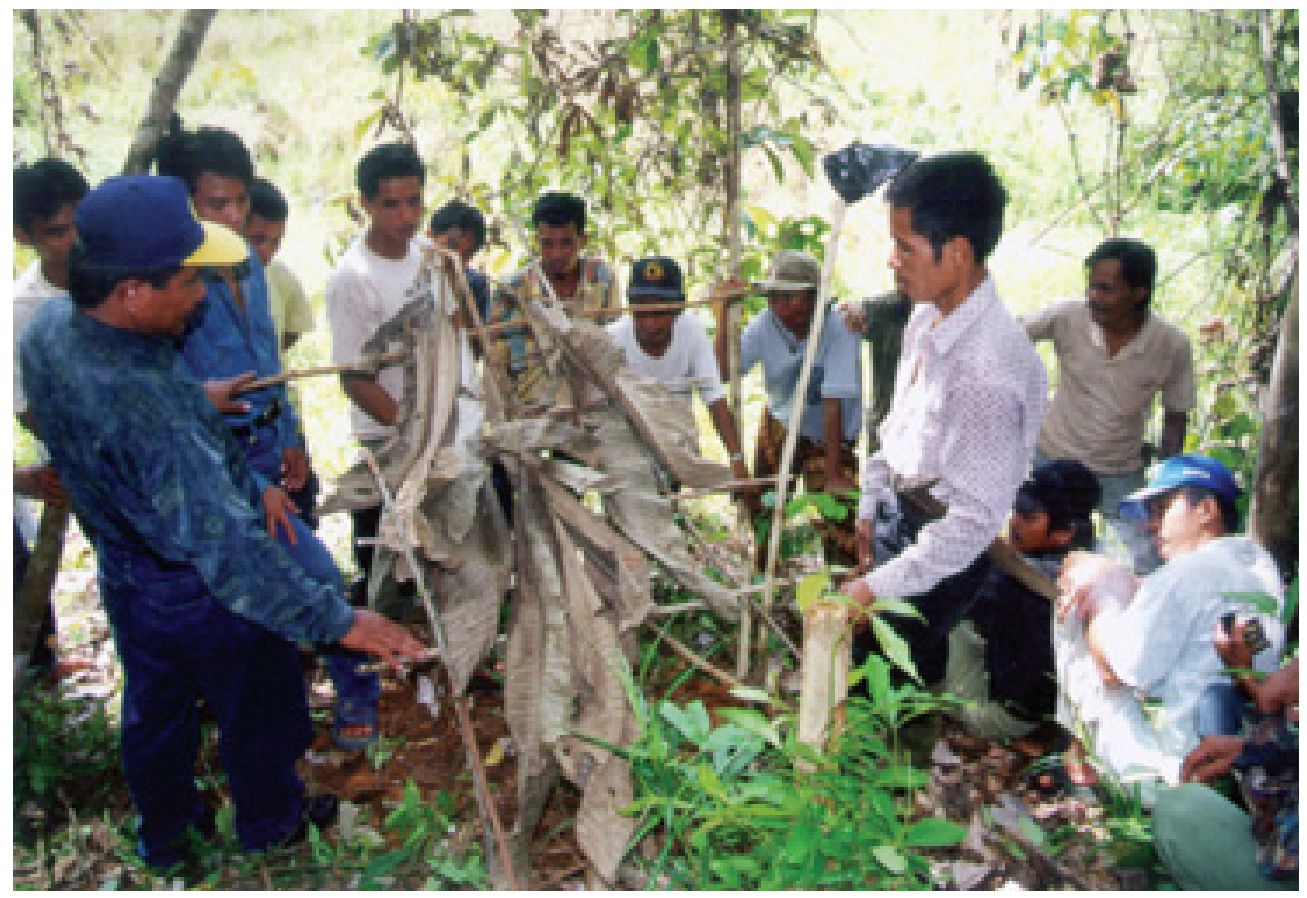

Pencarian fakta bersama seperti yang digambarkan disini membantu dalam memeriksa ketepatan pemahaman dan asumsi-asumsi yang ada. Gambar ini memperlihatkan sebuah kunjungan bersama oleh para petani di Pasir dan seorang petugas dinas kehutanan pada saat memeriksa lahan bekas perladangan yang ingin dimanfaatkan oleh masyarakat untuk meningkatkan pendapatan mereka.

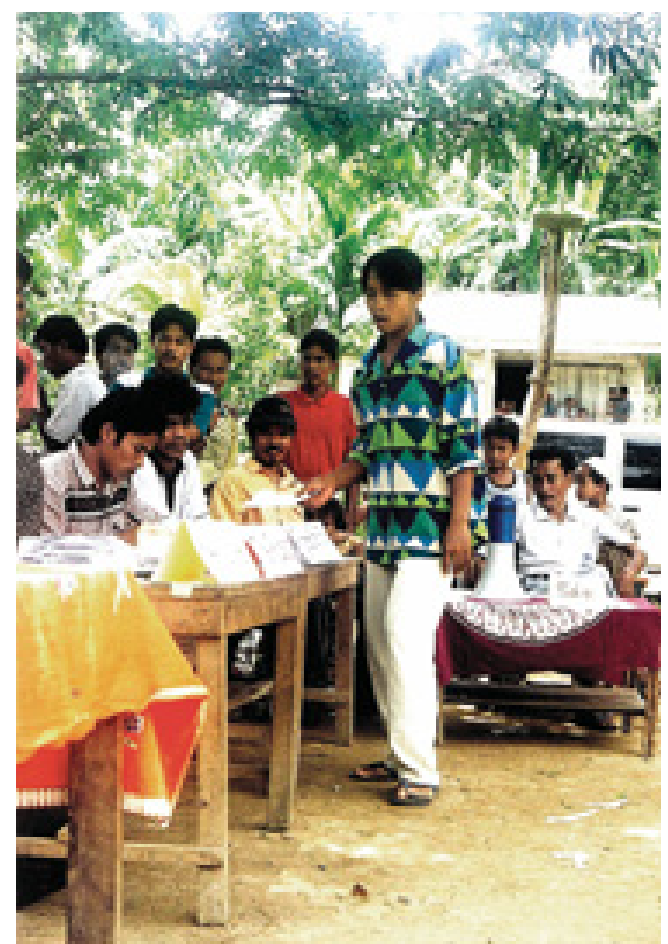

Para pemangku kepentingan masyarakat Baru Pelepat melewati proses pembelajaran dalam memilih para wakil mereka. Terlihat seorang perempuan akan memasukkan kertas suaranya dalam kotak pemungutan suara. 


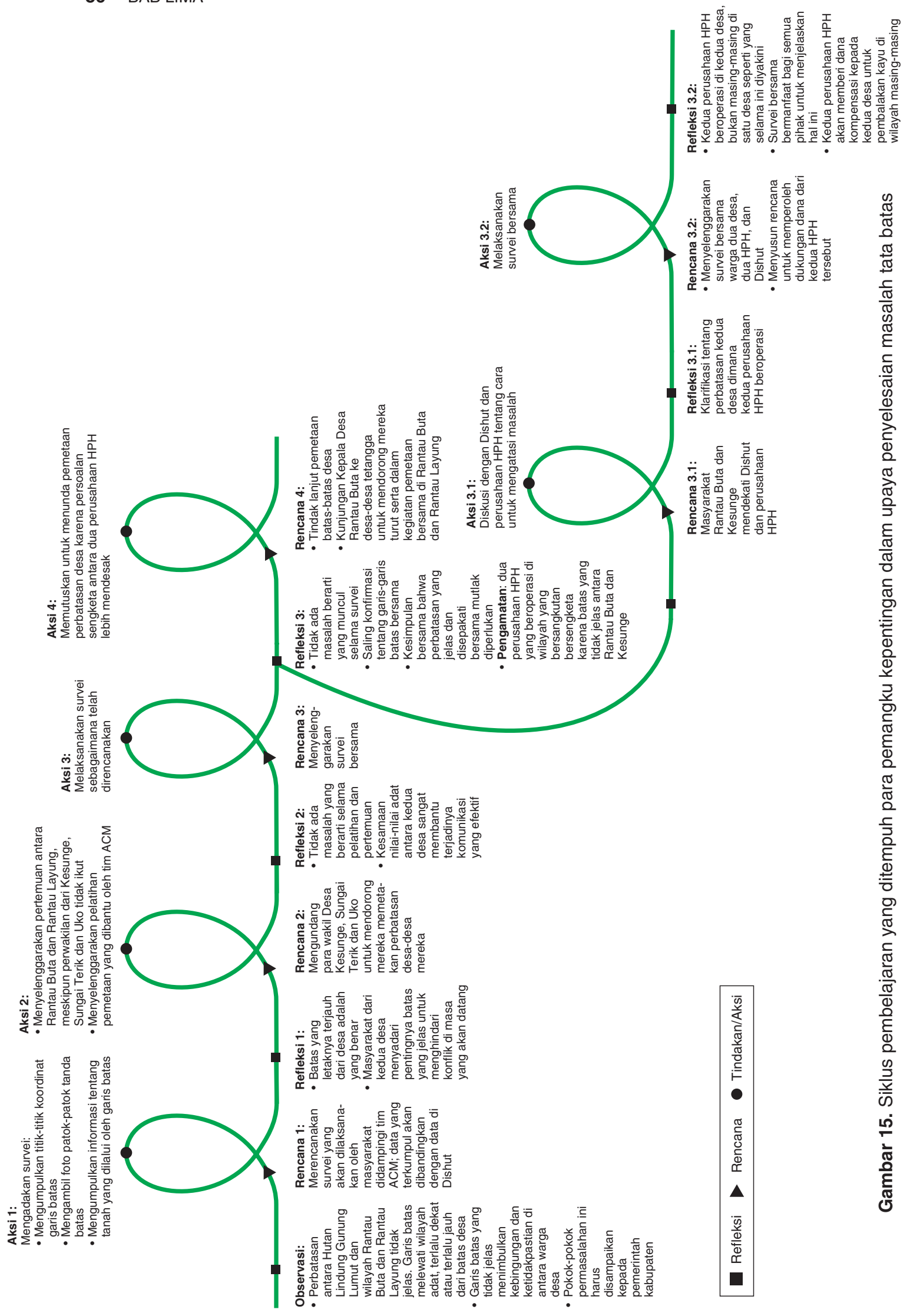




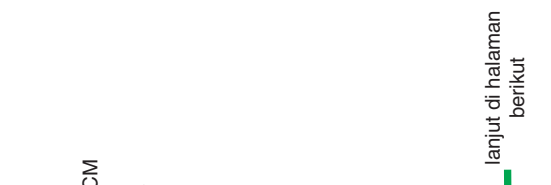

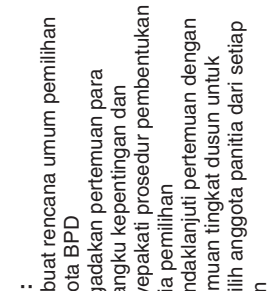

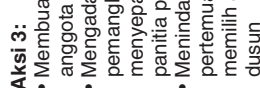
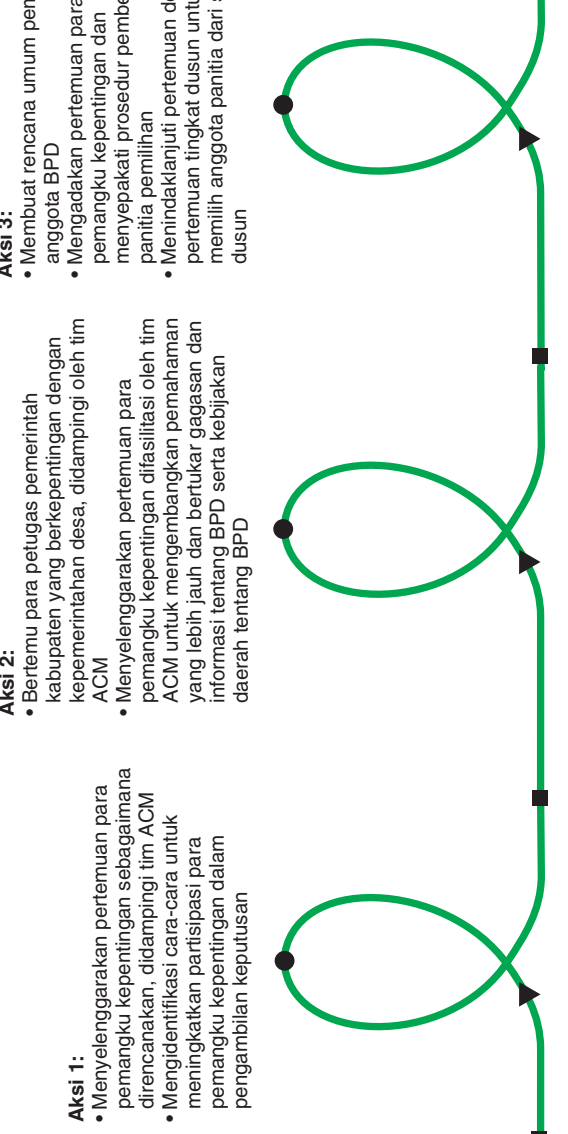

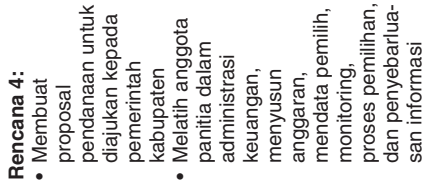

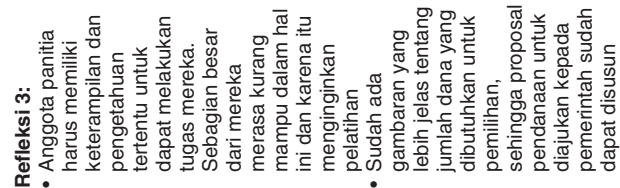

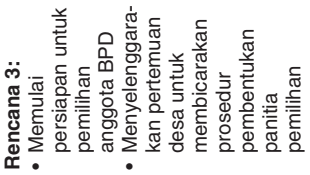

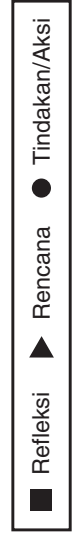

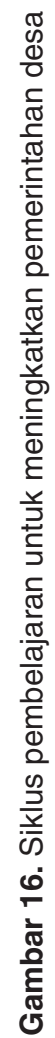

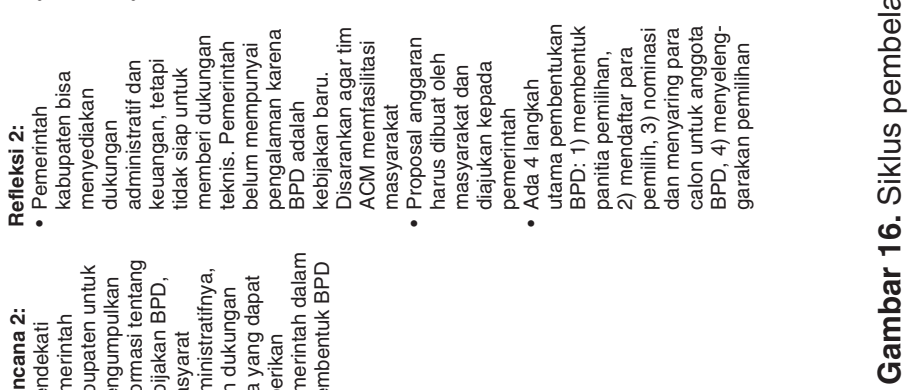

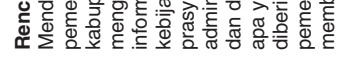

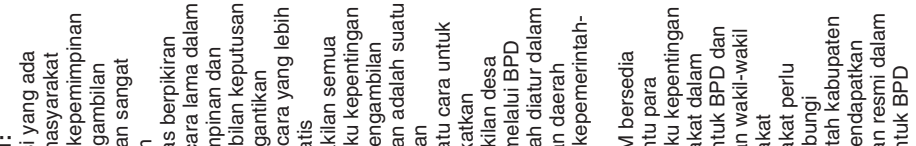

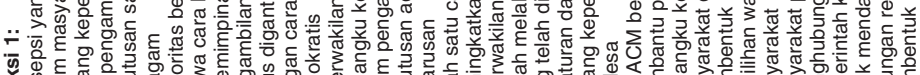

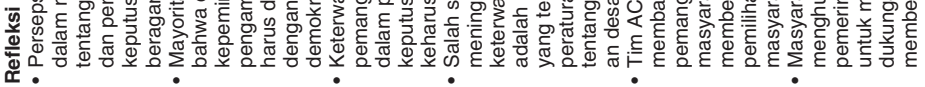

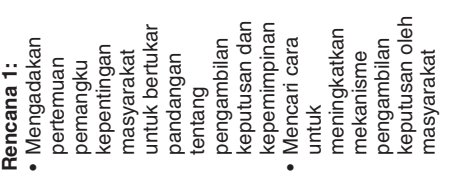

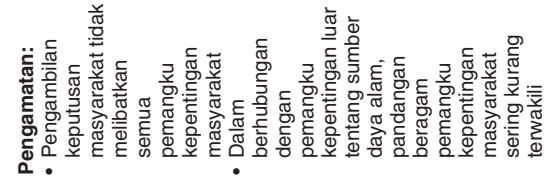



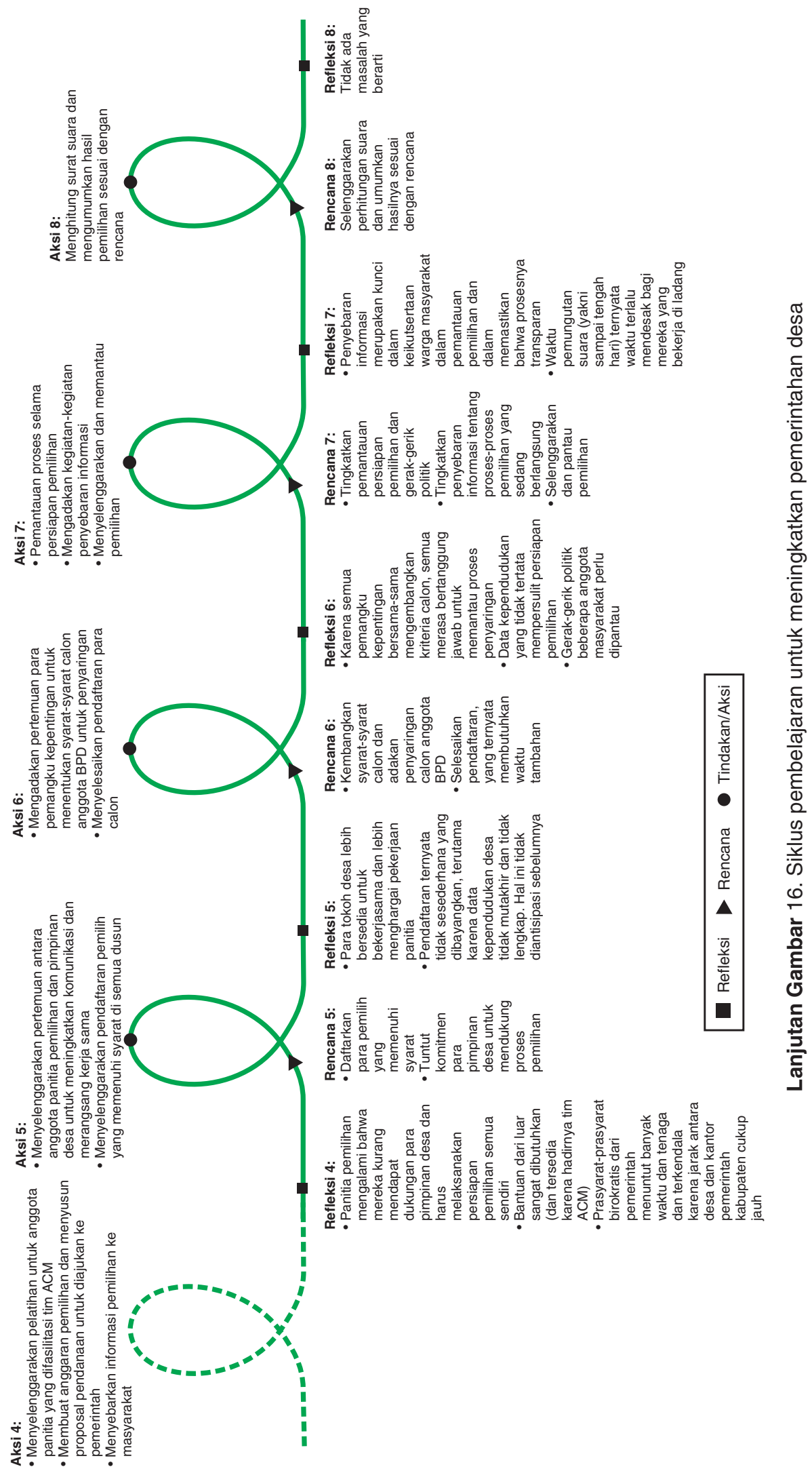

IDL 


\section{Prinsip 4: Pembelajaran melalui komunikasi}

Sewaktu berkegiatan bersama para pemangku kepentingan di kedua lokasi, sangat jelas bahwa ada prinsip lain yang diperlukan untuk terjadinya pembelajaran bersama yang efektif, yaitu kegiatan pembelajaran harus komunikatif.

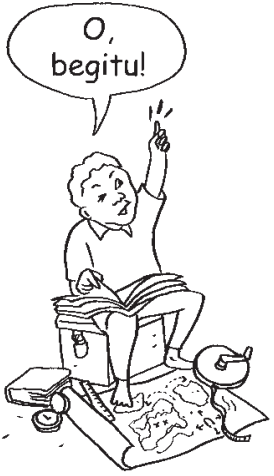

Kegiatan yang komunikatifadalah kegiatan yang membantu para pemangku kepentingan untuk menyatakan pandangan mereka kepada pihak lain secara lisan, non-verbal, ataupun dengan cara simbolis. Kegiatan semacam ini dapat berupa dialog atau pertemuan yang memungkinkan para pemangku kepentingan berkomunikasi melalui gambar, perumpamaan (metafora), atau permainan peran. Kegiatan sejenis ini memungkinkan dikomunikasikannya di antara para pemangku kepentingan pandangan masing-masing. Kegiatan itu membantu mereka mengembangkan pemahaman dan makna bersama yang lebih dalam tentang permasalahan yang dihadapi. Kegiatan-kegiatan semacam ini juga membantu pihak-pihak yang berbeda mencari cara-cara baru untuk mengartikulasikan pandangannya masing-masing. Interaksi dan komunikasi dengan pihak lain menjadi sumber penemuan hal-hal baru (discovery), pemahaman baru, dan "pencerahan" atau situasi "o, begitu!". Kegiatan pembelajaran melalui

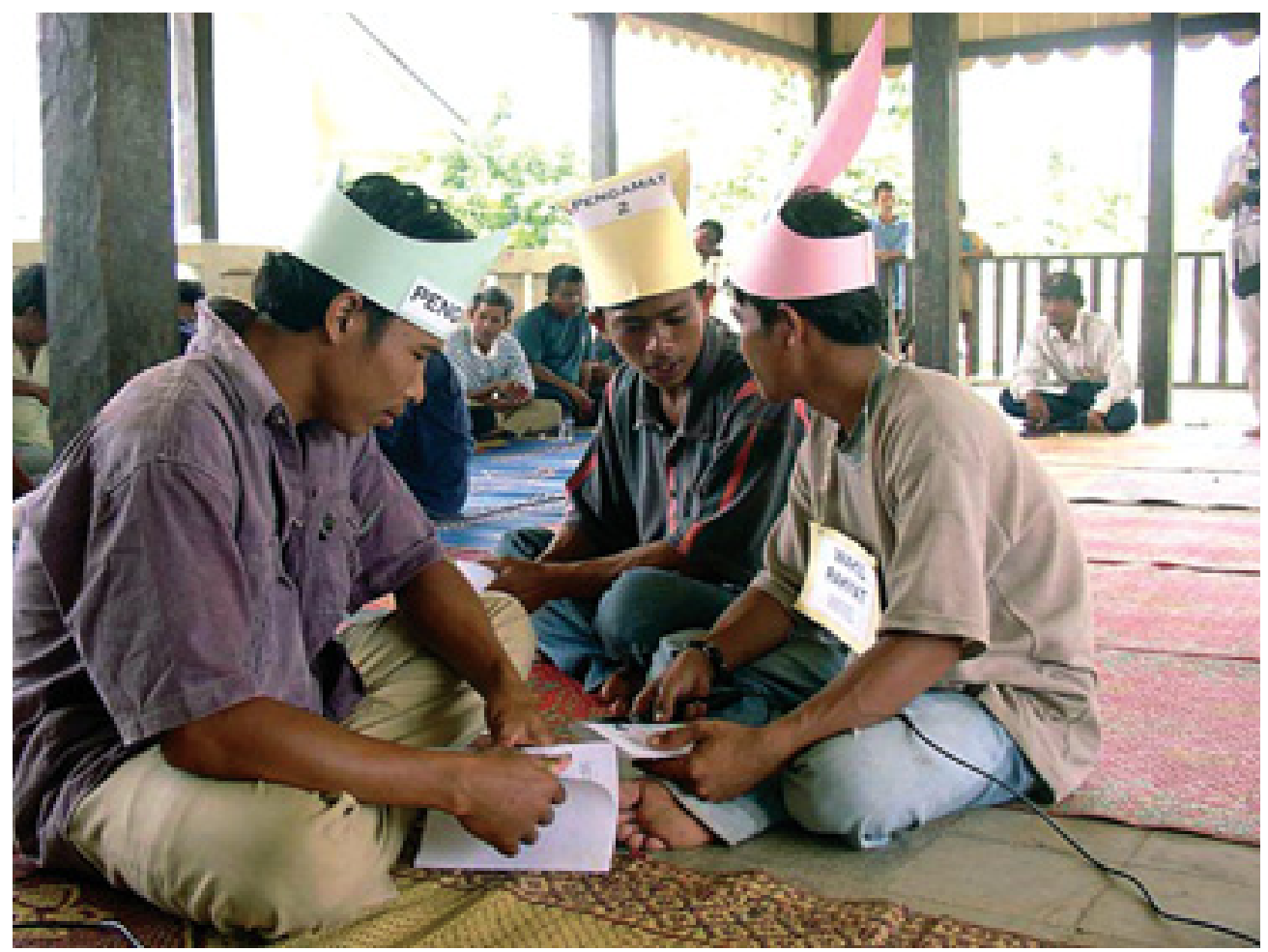

Permainan peran seperti yang nampak di sini dapat mendorong para pemangku kepentingan untuk menyatakan pandangan-pandangannya. 
komunikasi tidak hanya merangsang timbulnya semangat saling berbagi pemikiran, gagasan, dan informasi, tetapi juga mendorong terbentuknya sudut pandang baru dalam melihat sesuatu.

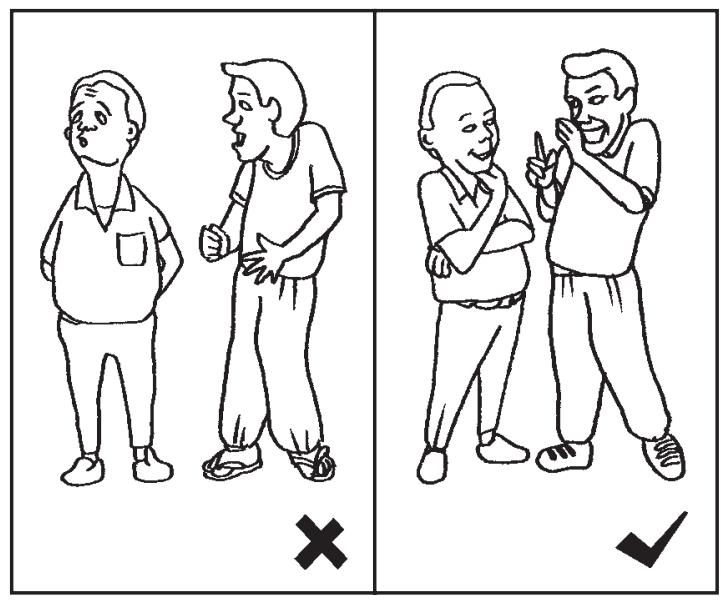

Aspek kunci dari prinsip ini adalah bahwa komunikasi terjadi secara adil dan berimbang. Dengan kata lain, setiap pemangkukepentingan berhak untuk memahami apa yang dikatakan pihak lain dan untuk dipahami oleh orang lain. Jika kondisi pembelajaran merangsang proses komunikasi yang setara, pertukaran pengetahuan dan informasi yang berimbang antara para pemangku kepentingan dapat terjadi.

\section{Apa arti prinsip 4 untuk kegiatan lapangan?}

Selama kegiatan lapangan berjalan, tim kami bukan saja semakin menyadari pentingnya prinsip ini, tetapi juga semakin memahami dan terampil dalam menerapkan prinsip ini dalam kegiatan lapangan. Pada awalnya kami berpikir bahwa meminta para pemangku kepentingan mengidentifikasi dan memprioritaskan masalah sudah cukup bagi mereka untuk mengatasi bersama masalahnya. Pada saat itu kami mengira bahwa sekali orang tahu apa yang harus dibicarakan—yakni, masalah yang ada—komunikasi akan terjadi dengan sendirinya. Namun kami melihat bahwa hal ini tidak selalu berlaku demikian. Kondisi yang mendorong terjadinya komunikasi yang berimbang nyaris tidak akan muncul dengan sendirinya: kondisi semacam itu harus secara sengaja diciptakan.

Gambar 17 menggambarkan proses komunikasi yang kelihatannya sederhana: pengirim pesan mengirim pesannya kepada penerima pesan. Setelah pesan itu diterima-dalam bentuk aslinya yang belum "terdistorsi"-penerima pesan memberi tanggapannya kepada pengirim pesan tadi. Pada saat umpan balik dikirim kepada pengirim pesan yang pertama, kita dapat mengatakan bahwa "komunikasi dua arah" sudah terjadi. Bukankah hal ini sederhana?

Namun, kami melihat di lapangan bahwa pada kenyataannya komunikasi tidak sesederhana itu. Kami menemukan berbagai faktor yang mengganggu komunikasi antara para pemangku kepentingan. Faktor-faktor yang paling menonjol adalah:

- Prasangka (stereotyping); dalam hal ini pemangku kepentingan tertentu dalam berkomunikasi mengaitkan pemangku kepentingan lainnya dengan pradugapraduga berdasarkan persepsi mereka sendiri (Kotak 22). 


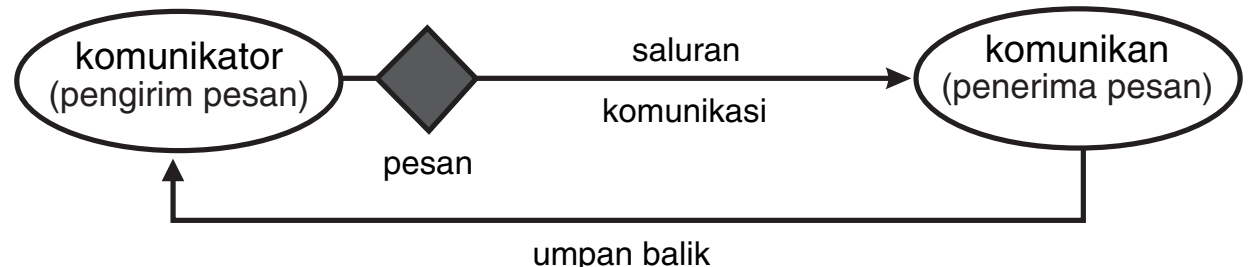

Gambar 17. Proses komunikasi yang terlihat sederhana

- Adanya agenda tertentu yang dimiliki pemangku kepentingan; mereka hanya memilih pesan-pesan yang sesuai dengan kepentingan mereka sendiri. Sebagai contoh, pada awalnya petugas kehutanan Pasir cenderung ragu untuk menerima saran masyarakat agar meninjau kembali tata batas antara desa masyarakat dengan Hutan Lindung Gunung Lumut. Para petugas tersebut terfokus pada agenda dinas mereka, yakni menjaga tata batas hutan lindung tersebut.

- Status sosial; dalam situasi ini para pemangku kepentingan dalam berkomunikasi cenderung lebih bereaksi terhadap status sosial pihak lain daripada terhadap pesan yang disampaikan. Komunikasi cenderung lebih terpengaruh oleh faktor ini ketika perbedaan status sosial cukup timpang antara pengirim dan penerima pesan, misalnya, antara tokoh adat dan kaum perempuan di Jambi.

Faktor-faktor yang mengganggu komunikasi bisa kita sebut "kebisingan" (noise); hal tersebut mengganggu kita dalam menerima pesan. Hasilnya bisa berupa "distorsi" pesan aslinya yang pada awalnya disampaikan oleh komunikator sehingga pesan yang diterima penerima pesan tersebut tidak sesuai dengan aslinya.

Kotak 22. Contoh-contoh prasangka (stereotyping)

Pasir:

- Pemerintah selalu lebih berpihak kepada perusahaan daripada mendukung masyarakat

- Masyarakat tidak melihat pentingnya upaya melindungi sumber daya hutan dan karena itu perlu dididik

Jambi:

- Kaum pendatang hanya mementingkan kemajuan kelompoknya sendiri

- Penduduk asli Minangkabau tidak mau bekerja sama 
Kami kemudian menyelenggarakan kegiatan-kegiatan yang menggunakan komunikasi sebagai sarana utama untuk berbagi pengetahuan dan pandangan. Pada saat yang bersamaan, kami mencoba untuk mengatasi gangguan-gangguan komunikasi yang kami sebutkan di atas dengan cara:

- Menciptakan suasana saling percaya dan saling menghargai di antara para pemangku kepentingan

- Mempersiapkan para pemangku kepentingan yang lemah dalam mengartikulasikan pandangannya agar mampu mengkomunikasikan pendapat mereka dan memberikan tanggapan secara efektif

- Mempersiapkan para pemangku kepentingan yang dominan untuk bisa lebih mendengarkan dan menyimak pesan yang diterimanya sebelum membentuk pendapat

- Mengambil peran sebagai juru bicara para pemangku kepentingan tertentu untuk menyampaikan pesan mereka.

Lampiran 2 memberikan beberapa contoh alat bantu yang dapat digunakan dalam mempraktekkan hal-hal ini.

\section{Memfasilitasi pembelajaran}

Di atas kita telah mendiskusikan prinsip-prinsip pokok yang mendasari penyelenggaraan pembelajaran untuk para pemangku kepentingan. Pada bagian ini, akan kami jelaskan bagaimana kami, sebagai fasilitator, mendorong terjadinya pembelajaran bersama (pembelajaran sosial) di antara para pemangku kepentingan.

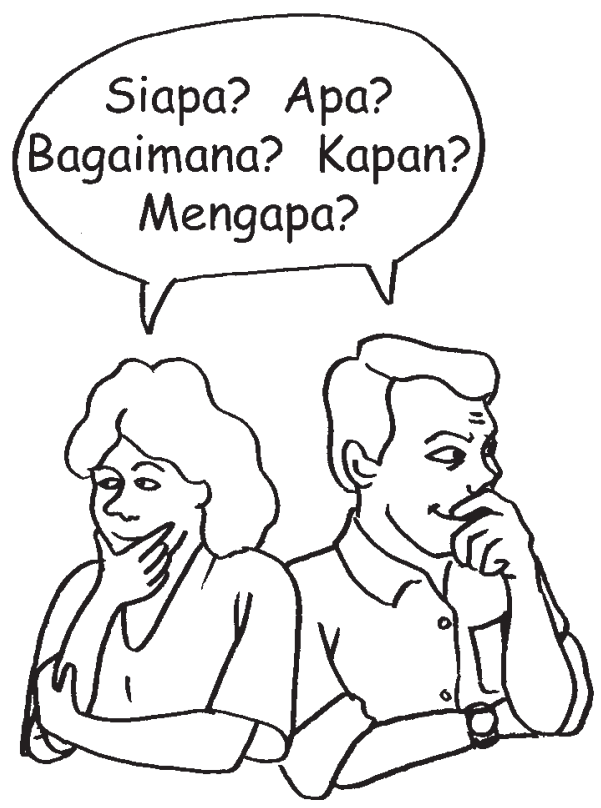


Dari pengalaman kami, cara kami memfasilitasi proses belajar sebagai individu, jauh lebih penting daripada alat ataupun metode fasilitasi yang kami gunakan. Pendekatan dan sikap kami sebagai individu nampaknya sangat mempengaruhi secara langsung proses interaksi sosial antara para pemangku kepentingan yang kami fasilitasi, yang pada gilirannya menentukan terjadi atau tidaknya pembelajaran. Ini berarti bahwa ketika memfasilitasi kami harus mencermati dengan hatihati bagaimana fasilitasi yang kami lakukan mempengaruhi proses pembelajaran dan mengapa hal ini terjadi. Untuk dapat mencermati hal ini, kami terpandu oleh lima pertanyaan sederhana: Siapa yang perlu difasilitasi? Apa saja kebutuhan pembelajaran mereka? Bagaimana cara memfasilitasi mereka? Kapan? Mengapa pembelajaran cenderung terjadi atau apa motivasi para pemangku kepentingan untuk belajar?

\section{Siapa?}

Mengetahui siapa yang difasilitasi merupakan pokok yang sangat mendasar dalam kegiatan fasilitasi. Sejauh mana kami secara sadar memusatkan fasilitasi kami pada siapa yang terlibat dalam pembelajaran, sangat menentukan terjadi atau tidaknya pembelajaran antara para pemangku kepentingan.

Pada tahap awal kegiatan lapangan, kami sudah mengidentifikasi dan menganalisis para pemangku kepentingan sehingga mengetahui siapa yang akan kami fasilitasi. Tetapi, hal ini baru merupakan informasi awal tentang keanekaragaman para pemangku kepentingan yang pembelajarannya akan difasilitasi. Dengan berjalannya kegiatan, informasi dasar ini perlu kami tinjau kembali, lengkapi, dan perdalami. Kelompok-kelompok pemangku kepentingan yang ada ternyata bisa berubah dan tidak bersifat tetap seperti kami perkirakan sebelumnya. Individu-individu di dalam suatu kelompok beraliansi dengan individu di kelompok lainnya, ataupun membentuk kelompok pemangku kepentingan baru di kemudian hari. Kami menyadari bahwa keanekaragaman atau diversitas pemangku kepentingan berubah dari waktu ke waktu dan, karenanya, kami harus waspada dan peka terhadap setiap perubahan yang terjadi pada keadaan pemangku-pemangku kepentingan di lokasi kami. Kotak 9 dan Kotak 10 pada hlm. 46 dan hlm. 48 memperlihatkan diversitas pemangku kepentingan yang kami temukan pada tahap awal proses dan yang sewaktuwaktu harus kami tinjau kembali.

Kami juga melihat bahwa sebagai fasilitator pembelajaran bersama kami harus mewaspadai apa dan mengapa keanekaragaman pemangku kepentingan terus berubah. Secara bertahap kami menyadari bahwa perubahan-perubahan tersebut dilatarbelakangi perubahan-perubahan kepentingan, dan dengan ini, permainan kekuatan antara para pemangku kepentingan. Karenanya, pertanyaan "siapa" tadi sebenarnya sama halnya dengan pertanyaan "siapa yang cukup berkuasa untuk dapat turut menentukan keputusan-keputusan yang diambil para pemangku 
kepentingan", ataupun pertanyaan "siapa yang tidak cukup berkuasa sehingga tidak/ kurang bersuara dalam pengambilan keputusan." Menyadari ada atau tidaknya ketimpangan antara para pemangku kepentingan, sangat krusial bagi kami selaku fasilitator pembelajaran bersama karena ketimpangan kekuasaan antara pemangku kepentingan dapat mempengaruhi proses pembelajarannya.

Hal di atas berarti bahwa mengetahui siapa yang berpartisipasi dalam kegiatan pembelajaran tidaklah cukup. Kami juga perlu memahami alasan-alasan di belakang setiap keputusan para pemangku kepentingan dalam menggunakan sumber daya alam dan apa yang mendasari hubungan antara para pemangku kepentingan ini. Untuk memperoleh informasi ini, yang merupakan latar belakang penting untuk pekerjaan fasilitasi kami, kami menggunakan suatu kerangka analisis yang berpusat pada tanggung jawab, hak, hasil dari hutan yang diperoleh para pemangku kepentingan, dan hubungan antara mereka. ${ }^{17}$ Lampiran 2 menampilkan informasi tentang hal ini untuk kasus di Baru Pelepat.

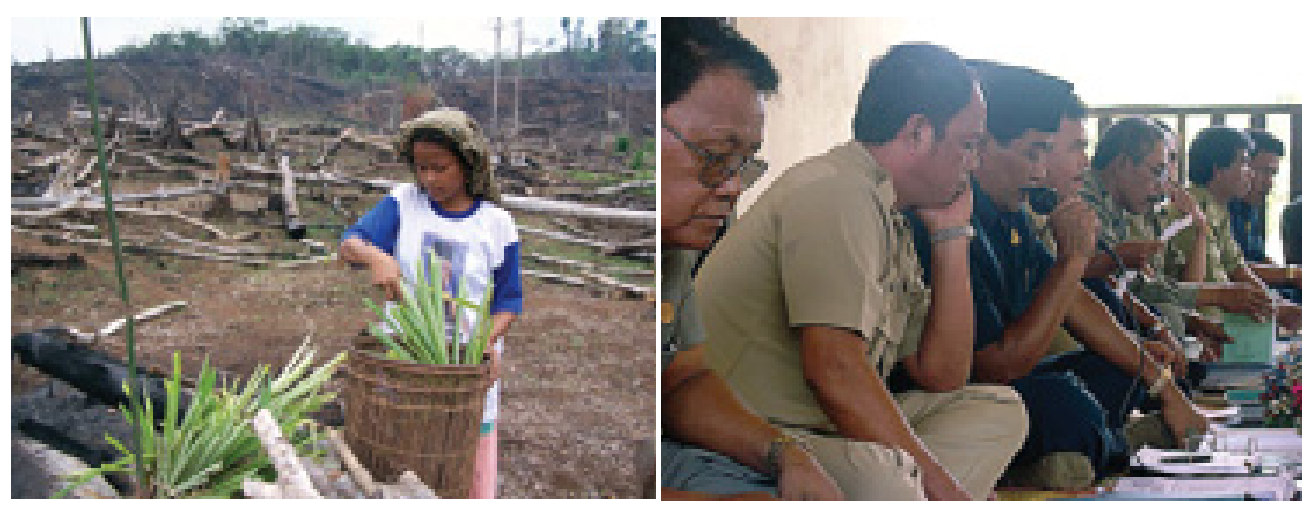

Mengetahui siapa yang perlu difasilitasi merupakan inti fasilitasi kami.

Mengetahui siapa yang terlibat dalam pembelajaran sosial juga penting bagi tim kami sebagai dasar untuk menyelenggarakan kegiatan pembelajaran. Dalam pembelajaran semacam ini, pemangku kepentingan yang satu mempengaruhi pembelajaran pihak lainnya. Karenanya, harus diperhatikan kapan suatu kumpulan pemangku kepentingan dapat belajar bersama atau kapan lebih baik bagi mereka masing-masing untuk belajar secara terpisah.

\section{Apa?}

Setelah menentukan siapa yang harus dilibatkan dalam proses pembelajaran, dengan sendirinya kami perlu menjawab pertanyaan pembelajaran apa yang akan dibutuhkan oleh para pemangku kepentingan ini? Berdasarkan penilaian kami sebelumnya tentang "kemampuan beradaptasi" dan "kemampuan berkolaborasi", kami memiliki pemahaman awal tentang mengapa tidaklah mudah bagi para pemangku kepentingan pada awal penelitian kami untuk merubah cara berpikir 
dan bertindak mereka yang lama, ataupun untuk berkolaborasi dengan pihak lain. Pemahaman awal ini memberi panduan untuk mengetahui apa yang menjadi kebutuhan belajar mereka.

Tetapi kami membutuhkan dasar yang lebih konkret sebagai pijakan kegiatan fasilitasi kami. Karena itu, kami melakukan suatu studi pustaka tentang pembelajaran sosial dan mencoba mencocokkan apa yang kami temukan dalam studi pustaka itu dengan apa yang kami amati di lapangan. Sementara kami melakukan studi pustaka dan mempertemukan para pemangku kepentingan dalam menjalankan proses penelitian aksi partisipatif, kami menemukan sebuah definisi pembelajaran sosial yang sangat membantu dalam mengoperasionalkan konsep pembelajaran sosial dalam fasilitasi kami. Menurut definisi ini, pembelajaran sosial dapat dipahami dengan menghubungkannya dengan empat dimensi dari arti kata "sosial": ${ }^{18}$

- Pengembangan pengetahuan oleh kelompok pemangku kepentingan tertentu di dalam kelompok itu sendiri. Di lapangan kami menemukan bahwa proses ini terjadi terutama ketika suatu kelompok melakukan refleksi atas tindakan mereka sebelumnya atau ketika membuat rencana sebagai dasar untuk aksi baru atau untuk interaksi mendatang dengan pemangku kepentingan lainnya.

- Pengembangan komunikasi dan hubungan antara para pemangku kepentingan. Kami mengamati bahwa sejalan dengan kegiatan pembelajaran yang berulangulang, para pemangku kepentingan membangun kesadaran tentang adanya saling ketergantungan antara mereka. Pada gilirannya hal ini membangun rasa saling menghargai. Kepercayaan timbal balik berkembang secara bertahap di antara mereka. Meningkatnya komunikasi dan hubungan sosial ini kemudian merangsang terjadinya saling berbagi pengetahuan, yang sering menjadi dasar tindakan bersama.

- Berbagi pengetahuan antara para pemangku kepentingan. Ketika para pemangku kepentingan belajar bersama, pertukaran informasi dan pengetahuan terjadi. Hal ini menjadi dasar berkembangnya pemahaman-pemahaman bersama baru. Dalam proses ini, para pemangku kepentingan membawa pengetahuan dan sumber daya lainnya yang masing-masing mereka miliki ke dalam proses saling berbagi itu.

- Proses-proses politis. Kami melihat bahwa proses-proses politis mendorong para kelompok pemangku kepentingan untuk mengembangkan kapasitas strategisnya, misalnya, kemampuan mereka untuk bernegosiasi dalam menentukan batas desa.

Kami mengamati bahwa keempat proses sosial ini tidak hanya muncul ketika para pemangku kepentingan belajar bersama, tetapi bahwa proses-proses tersebut juga menjadi dasar untuk pembelajaran bersama selanjutnya. Oleh karena itu, kami melihat bahwa keempat proses sosial itu dapat dijadikan acuan untuk mengetahui apa yang menjadi kebutuhan belajar para pemangku kepentingan. 
Kami menggunakan pemahaman ini dalam memandu fasilitasi kami seperti diperlihatkan Kotak 23. Pemetaan batas desa dan kegiatan negosiasi yang dilakukan masyarakat desa di lokasi Jambi dan lokasi Pasir dengan masyarakat desa-desa sekitarnya, perusahaan HPH, dan pemerintah merupakan contoh bagaimana kami memadukan keempat kebutuhan pembelajaran ini ke dalam kegiatan fasilitasi kami.

Kotak 23. Empat kebutuhan belajar para pemangku kepentingan: Beberapa contoh

\section{Mengembangkan pengetahuan di dalam kelompok kepentingannya sendiri}

Pengetahuan masyarakat tentang batas desa mereka dikembangkan melalui pengamatan lapangan dan pengumpulan data geografis. Tim ACM menyediakan pelatihan tentang bagaimana menggunakan peranti sistem penentuan posisi geografis (GPS) untuk mengukur posisi geografis. Dengan cara ini diciptakan peluang bagi masyarakat untuk mempelajari posisi geografis batas-batas desa mereka. Pengetahuan ini kemudian digunakan sebagai dasar perundingan dengan masyarakat desa-desa lain di sekitar desa mereka.

\section{Mengembangkan komunikasi dan hubungan dengan para pemangku} kepentingan lain

Kunjungan lapangan bersama telah mendorong masyarakat desa-desa yang bertetangga untuk belajar saling mendengarkan dan berbicara. Dengan kata lain, mereka belajar bagaimana berkomunikasi dan membangun hubungan. Aturan adat sering digunakan sebagai dasar komunikasi semacam ini. Hal ini dimungkinkan karena masyarakat yang desa-desanya bertetangga mempunyai aturan-aturan adat yang sangat mirip. Ketika komunikasi lisan menjadi terlalu abstrak, kami menyarankan agar semua pihak yang terlibat berkunjung ke lapangan untuk melihat seperti apa kenyataannya.

\section{Berbagi pengetahuan dengan para pemangku kepentingan lain}

Pengetahuan tentang batas-batas desa yang dikembangkan oleh masyarakat desa dibagi di antara mereka. Pada awalnya, arus informasi dan pengetahuan lebih bergerak dari masyarakat yang kami fasilitasi ke arah masyarakat desadesa lain di sekitar mereka; tetapi dalam proses selanjutnya masyarakat desadesa lain itu juga mulai berkontribusi terhadap proses berbagi pengetahuan dan informasi itu. Masing-masing kelompok masyarakat menyadari bahwa kelompok masyarakat lainnya memiliki pengetahuan yang berharga yang bisa melengkapi pengetahuan mereka sendiri. Proses saling berbagi pengetahuan difasilitasi melalui pertemuan-pertemuan formal, informal, dan pencarian fakta bersama di lapangan. 


\section{Pengembangan kemampuan strategis atau politis para pemangku} kepentingan

Untuk kebutuhan belajar ini, kita dapat melihat contoh dari Jambi. Sebagai hasil negosiasi dengan masyarakat desa tetangga, masyarakat Baru Pelepat belajar bagaimana membangun kemampuan strategis atau politis mereka. Kami mendorong pembelajaran semacam ini dengan memfasilitasi para perunding merefleksikan proses-proses negosiasi, keluaran-keluaran dari negosiasi itu, dan pelajaran yang dapat diperoleh dari proses negosiasi. Kotak 24 memberikan sebuah contoh tentang peningkatan kapasitas negosiasi masyarakat dan, karenanya, peningkatan kemampuan strategis mereka.

Kotak 24. Meningkatkan kemampuan strategis dalam bernegosiasi

Pada sebuah pertemuan negosiasi tentang batas desa dengan wakil-wakil dari Desa Sungai Beringin, dua orang tokoh adat Baru Pelepat berselisih. Salah satu dari mereka berpikir bahwa ia mengetahui peraturan adat lebih baik daripada yang lainnya. Sekembalinya dari pertemuan, ketika melakukan refleksi, kedua tokoh adat ini bersumpah bahwa hal ini tidak akan terjadi lagi karena ternyata telah mempermalukan Baru Pelepat. Mereka percaya: "Seekor ayam hanya bisa dipotong sekali saja”. Mereka belajar bahwa mereka jangan sampai melakukan kesalahan yang sama lagi dan sebelum berangkat ke meja perundingan, wakilwakil Baru Pelepat harus sepakat dulu di antara mereka sendiri tentang apa yang akan dirundingkan dan bagaimana cara melakukannya.

\section{Bagaimana?}

Tentang bagaimananya pembelajaran sosial antara para pemangku kepentingan, berikut ini dapat dibaca tiga aspek kunci yang diangkat dari pengalaman lapangan kami.

Selama melakukan kegiatan fasilitasi, kami menemukan dua cara pembelajaran yang dapat cukup memicu para pemangku kepentingan untuk mengadopsi perilaku dan cara berpikir yang baru serta bersikap lebih terbuka dalam berinteraksi dengan pihak lain. Kedua cara pembelajaran tersebut kami sebut pembelajaran "investigatif" dan pembelajaran "reflektif". Kami amati bahwa pembelajaran dapat menghasilkan keluaran yang positif jika kedua jenis pembelajaran ini saling berurutan dalam suatu siklus yang dilakukan secara berulang-ulang (Gambar 18).

Kami memfasilitasi cara belajar investigatif dengan merangsang para pemangku kepentingan untuk bersikap ingin tahu (Kotak 25) serta cara belajar reflektif 
dengan mendorong mereka untuk "memperlambat proses berpikir" (Kotak 26). Kedua cara belajar yang saling melengkapi ini membantu kami dalam mengembangkan kesadaran para pemangku kepentingan bahwa asumsi-asumsi mereka mempengaruhi tindakan dan pembentukan model mental mereka. Maka dari itu, kami mengadopsi kedua cara belajar tersebut sebagai panduan untuk mengetahui bagaimana memfasilitasi pembelajaran antara para pemangku kepentingan, pada titik manapun mereka berada dalam siklus penelitian aksi partisipatif, apakah pada tahap perencanaan, aksi, refleksi atas aksi, ataupun pengamatan.

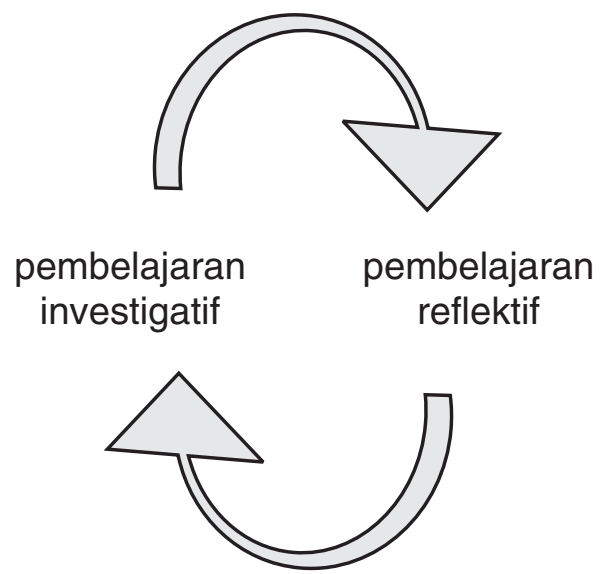

Gambar 18. Cara pembelajaran para pemangku kepentingan: Pembelajaran yang investigatif dan reflektif yang terjadi berulang-ulang

Kotak 25. Memotivasi para pemangku kepentingan untuk bersikap ingin tahu: Pembelajaran investigatif

Ada beberapa cara yang dapat dipakai fasilitator untuk mendorong para pemangku kepentingan agar bersikap ingin tahu:

- Dalam mendiskusikan pokok-pokok persoalan, mulailah dengan pertanyaan yang bersifat umum dan kemudian secara bertahap meningkat ke pertanyaanpertanyaan yang lebih terinci dan mendalam. Hal ini akan membuat seseorang secara bertahap lebih "haus" akan hal-hal rinci dan lebih "analitis".

- Makin tinggi motivasi seseorang untuk mencari tahu hal-hal yang rinci, semakin berhati-hati ia untuk tidak terlalu cepat mengambil kesimpulan dan semakin terbuka terhadap apa yang dikatakan orang lain.

- Bangunlah di atas apa yang sudah diketahui: aktifkan dasar pengetahuan yang sudah ada. Hal ini akan memicu orang untuk memperdalam pemahaman mereka tentang hal-hal yang telah mereka ketahui. Hal ini juga akan membantu dalam menguji kembali asumsi-asumsi mereka. Pertanyaan "kita tahu banyak, tetapi apakah kita benar-benar memahami apa yang kita ketahui?" bisa membantu. 
Kotak 26. Jangan cepat mengambil kesimpulan: Pembelajaran reflektif

Sebagai manusia kita sering cenderung untuk segera bereaksi ketika mendengar seseorang berbicara. Reaksi atau tindakan kita yang segera itu bisa jadi kurang berhubungan dengan apa yang sesungguhnya dikatakan orang lain. Fasilitator pembelajaran bersama sebaiknya mendorong para pemangku kepentingan untuk mengambil waktu yang cukup untuk mengartikan sebuah pesan atau pengamatan.

Mengambil kesimpulan setelah proses berpikir yang memadai kadang disebut juga dengan "mendaki tangga kesimpulan" (climbing-up the ladder of inference). Ada juga yang menyebut "memperlambat proses berpikir" ini sebagai "mencerminkan pikiran seseorang". Hal ini dapat membantu kita menelaah secara kritis asumsiasumsi kita.

Cobalah praktekkan cara ini pada diri Anda sendiri, dan jika Anda tidak mendapatkan suatu hasil, mungkin cermin Anda perlu dibersihkan!

Selain perlu mengetahui bagaimana memfasilitasi proses belajar, tentu kami juga membutuhkan metode untuk melakukannya. Kami menggunakan tiga jenis metode ${ }^{19}$ dalam fasilitasi kami, yakni dengan mendorong para pemangku kepentingan untuk: 1) mengalaminya sendiri; 2) mengamati pengalaman orang lain; atau 3) membuat "model" (yakni gambaran yang lebih abstrak, terkadang bahkan lebih sederhana) dari situasi nyata. Kotak 27 memaparkan beberapa contoh yang mengilustrasikan ketiga cara fasilitasi pembelajaran ini.

Berkaitan dengan pertanyaan bagaimana memfasilitasi, masih ada satu hal terakhir yang patut diperhatikan. Ketika kami memfasilitasi pembelajaran antara para pemangku kepentingan, pertanyaan tentang bagaimana memfasilitasi pembelajaran sangat bergantung pada siapa yang difasilitasi (lihat hlm. 93). Dalam prakteknya hal ini berarti bahwa fasilitasi kami harus mempertimbangkan preferensi masing-masing pemangku kepentingan tentang bagaimana cara belajarnya.

Sebagai contoh, kami mengamati bahwa di kedua lokasi kajian, kaum perempuan lebih menyukai lingkungan belajar yang santai, informal dan tidak terlalu terstruktur, yakni tidak menggunakan suatu format khusus. Mereka cenderung enggan berbicara dalam pertemuan yang lebih besar dan bersifat resmi. Karena alasan ini, pembelajaran bagi mereka sebaiknya memadukan cara-cara yang terstruktur dan resmi dengan pertemuan-pertemuan informal. Sering kami juga menyelenggarakan pertemuan terpisah untuk kaum perempuan guna mempersiapkan mereka sebelum menghadapi pertemuan yang lebih besar dengan para pemangku kepentingan lainnya. 
Kotak 27. Tiga cara memfasilitasi pembelajaran: Contoh dari Jambi

- Mengembangkan pengalaman: Untuk membantu meningkatkan keterwakilan dalam pengambilan keputusan masyarakat, kami memfasilitasi suatu proses untuk pemilihan para wakil para pemangku kepentingan yang akan menjadi anggota BPD. Beberapa pengalaman belajar yang kami fasilitasi adalah: lokakarya tentang kepemimpinan dan keterwakilan di tingkat desa, penunjukan panitia pemilihan, penyiapan para pemangku kepentingan masyarakat untuk menghadapi proses pemilihan, pemilihan anggota BPD, dan penunjukan resmi para wakil masyarakat.

- Mengamati pengalaman orang lain: Pada sebuah pertemuan para pemangku kepentingan desa, seorang pemimpin adat dari suatu desa di Sumatera Barat diundang untuk berbagi pengalaman tentang upaya-upaya di desa asalnya dalam mengembangkan mekanisme kerja sama antara lembaga adat dan pemerintah desa.

- Membuat model: Pada suatu lokakarya, para pemangku kepentingan masyarakat difasilitasi untuk mengembangkan pemahaman tentang keterwakilan. Peserta diminta untuk memberi penilaian terhadap wakil yang "baik" dan yang "buruk" dengan bermain peran. Proses pembuatan model ini mendorong para peserta untuk mengidentifikasi ciri-ciri wakil yang "baik" dan yang "buruk". Dengan meminta peserta menyampaikannya dalam bentuk permainan peran, mereka didorong untuk merumuskan ciri-ciri yang harus dimiliki seorang wakil dengan istilah-istilah umum yang mudah dimengerti masyarakat. Dengan cara seperti ini, model yang dihasilkan menjadi sumber pengetahuan yang melengkapi pengetahuan dan pengalaman yang telah dimiliki sebelumnya.

\section{Kapan?}

Pertanyaan mengenai kapan memfasilitasi pembelajaran berkaitan erat dengan tiga pertanyaan sebelumnya, sehingga pertanyaan kapan dalam fasilitasi dapat dijadikan rangkaian pertanyaan sebagai berikut: "Kapan waktu yang paling tepat untuk memfasilitasi siapa, tentang apa, dan bagaimana melakukannya?"

Dalam prakteknya, hal ini berarti bahwa kami harus mengembangkan kepekaan dalam memilih waktu yang tepat untuk memfasilitasi para pemangku kepentingan yang kebutuhan dan preferensi cara belajarnya saling berbeda. Sebagai contoh, marilah kita kembangkan contoh kelompok perempuan yang diberikan di atas tadi. Dalam kasus kelompok perempuan itu (siapanya), mereka membutuhkan pendampingan kami dalam mengembangkan pengetahuan dan keterampilan mereka sebelum berpartisipasi dalam pertemuan forum para pemangku kepentingan yang lebih besar dan lebih resmi (kapannya). Persiapan ini terpusat pada pengembangan pengetahuan dasar dan keterampilan kaum perempuan, dalam hal kemampuan komunikasi dan berbagi pengetahuan dengan pihak lain 
(apanya). Pada pertemuan dengan pihak lain yang diselenggarakan sesudah itu (kapannya lagi), kaum perempuan menerapkan apa yang telah mereka persiapkan sebelumnya dan mengalami sendiri (bagaimananya) proses saling berbagi pengetahuan dengan pihak lain melalui komunikasi.

\section{Mengapa?}

Akhirnya, untuk memfasilitasi pembelajaran secara efektif, penting bagi kita untuk bertanya pada diri kita sendiri mengapa para pemangku kepentingan bersedia mengorbankan waktu luang mereka untuk belajar bersama kita. Dengan kata lain, untuk memahami peran kita sebagai fasilitator pembelajaran, kita harus mencari tahu apa yang sebenarnya menjadi motivasi para pemangku kepentingan untuk belajar. Tim kami mengamati bahwa ada tiga faktor motivasi (Kotak 28) dan berdasarkan pengetahuan itu kami memfasilitasi setiap situasi sesuai dengan motivasi yang dapat memicu pembelajaran para pemangku kepentingan yang difasilitasi (Tabel 1):

- Para pemangku kepentingan termotivasi oleh faktor-faktor eksternal

- Para pemangku kepentingan termotivasi oleh faktor-faktor internal

- Para pemangku kepentingan termotivasi untuk belajar karena terdorong oleh proses-proses interaktif yang terjadi selama pembelajaran bersama.

Kotak 28. Tiga faktor yang menjadi motivasi para pemangku kepentingan untuk belajar bersama: Beberapa contoh

1. Faktor eksternal: Masyarakat di Pasir memprakarsai negosiasi dengan pemerintah dan perusahaan HPH mengenai batas desa dalam upaya untuk dapat turut menentukan bagaimana mengelola sumber daya alam desa mereka. Mereka berpendapat, jika batas desa jelas dan mereka memperoleh pengakuan atas batas tersebut, maka sumber penghidupan masyarakat desa akan lebih terjamin. Dalam keadaan ini, kedatangan tim kamilah yang memicu semangat mereka untuk lebih memastikan wilayah kelola desa mereka. Keinginan untuk meningkatkan kondisi penghidupan sebenarnya telah ada sejak sebelum kedatangan kami, tetapi fasilitasi kamilah yang mendorong masyarakat untuk mengupayakannya.

2. Faktor internal: Sebagai manusia, kita memiliki kemampuan untuk "melihat masa depan". Faktor tersebut sifatnya internal karena tidak memerlukan motivasi luar (eksternal). Hal ini karena manusia mempunyai kemampuan belajar, atau kemampuan kognitif, yang memungkinkannya untuk menghubungkan pengalaman atau pengamatan masa lalu dengan situasi yang mungkin akan terjadi di masa mendatang. Dengan kata lain, sebagai manusia kita bisa memperkirakan konsekuensi dari hal-hal yang belum terjadi. Beberapa orang menyebut kemampuan ini sebagai kemampuan belajar antisipatif. Meskipun semua orang memilikinya, kemampuan semacam ini bisa ditingkatkan melalui fasilitasi. ${ }^{20}$ 
Di Baru Pelepat kami memfasilitasi pembelajaran antisipatif ini untuk membantu masyarakat desa mengambil tanggung jawab baru yang muncul dari kebijakan desentralisasi pemerintah, termasuk kebijakan yang mengalihkan beberapa wewenang pengambilan keputusan kepada pemerintah desa. Dalam suatu lokakarya, kami meminta warga desa untuk mendiskusikan apa yang akan mereka lakukan jika ada pengusaha swasta datang menemui mereka dan menawarkan kerja sama dalam memanfaatkan hasil hutan. Gambar 19 memperlihatkan sebuah gambar yang kami gunakan untuk memicu diskusi tersebut. Dalam kasus ini, kami mendampingi para peserta untuk melakukan refleksi tentang situasi serupa yang pernah mereka alami atau amati sebelumnya. Dalam melakukan ini kami mendorong mereka untuk tetap terfokus pada masa depan dengan memberi informasi tentang apa yang bisa terjadi di masa yang akan datang. Kami menyediakan informasi, antara lain tentang kebijakan-kebijakan pemerintah tentang pemerintahan desa dan kemungkinan adanya minat investor swasta terhadap hasil hutan di wilayah desa. Dengan kata lain, kami mendampingi para pemangku kepentingan dalam mengembangkan kemampuannya untuk mengantisipasi masa depan.

3. Proses interaktif antara para pemangku kepentingan: Peran kami dalam hal ini adalah mendorong komunikasi antara para pemangku kepentingan. Dengan kata lain, peran kami adalah memfasilitasi proses-proses berkelompok.

- Dengan kehadiran orang atau kelompok lain, seseorang atau suatu kelompok cenderung belajar dengan lebih baik. Sebagai contoh, karena latar belakang sejarah dan pengalaman yang berbeda, perempuan Minangkabau pada awalnya merasa kurang percaya diri jika harus berbicara di muka umum dibandingkan dengan kaum perempuan pendatang. Namun kami mengamati pula bahwa karena kehadiran kaum perempuan pendatang, perempuan Minangkabau termotivasi untuk juga ikut berbicara dalam pertemuan yang lebih besar. Nampaknya seolah-olah mereka berpikir: "apa yang bisa dilakukan perempuan pendatang, kita juga bisa".

- Kelompok yang terdiri dari beragam peserta, mengembangkan pemahaman yang lebih kaya tentang permasalahan yang didiskusikan. Hal ini dicontohkan oleh proses negosiasi antara masyarakat Pasir, pemerintah, dan pengusaha $\mathrm{HPH}$. Selama negosiasi ini, setiap pemangku kepentingan memperkaya diskusi dengan menambahkan perspektif khas mereka.

- Para pemangku kepentingan merasa bahwa menilai tepat atau tidaknya suatu keputusan yang diambil akan lebih mudah jika dilakukan dalam kelompok. Di samping itu, karena pada umumnya lebih mudah untuk menilai kekurangan pihak lain daripada kekurangan diri sendiri, mereka bisa saling mengoreksi jika berkelompok. Demikian pula, sebagai kelompok mereka dapat mengingat fakta dengan lebih baik sehingga pilihan-pilihan dalam mengambil keputusan bisa dinilai dengan lebih tepat. Memang, sebagaimana kami amati, ingatan kelompok lebih kuat daripada ingatan masing-masing pemangku kepentingan yang ada di dalam kelompok tersebut secara terpisah. 
Tabel 1. Contoh motivasi belajar para pemangku kepentingan dan peran fasilitasi

\section{Motivasi belajar}

para pemangku kepentingan

Keinginan untuk menghentikan pembalakan kayu secara berlebihan yang dilakukan orang luar desa (motivasi eksternal)

Hasrat untuk tahu apa yang mungkin terjadi di masa depan (motivasi internal)

Proses interaktif selama pembelajaran

\section{Peran fasilitasi}

Memicu pembelajaran untuk terjadinya perubahan
Mendampingi dalam mengembangkan kemampuan para pemangku kepentingan dalam mengantisipasi

Mendorong komunikasi antara para pemangku kepentingan, yakni memfasilitasi proses interaktif di antara mereka

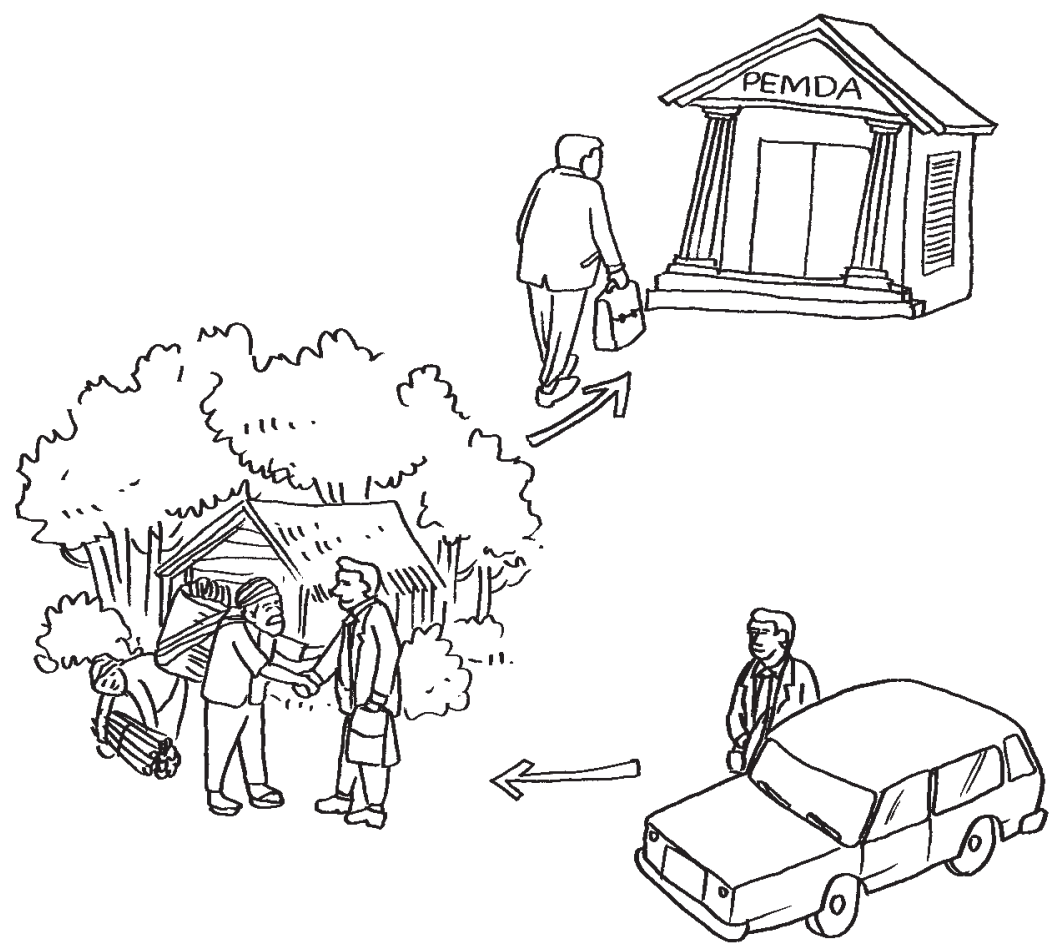

Gambar 19. Sebuah gambar yang kami pakai untuk memicu diskusi di antara para pemangku kepentingan 


\subsection{Keluaran Pembelajaran}

Tujuan utama para pemangku kepentingan di kedua lokasi penelitian adalah peningkatan penghidupannya. Namun demikian, pada awal kegiatan kami, mereka merasa bahwa hal tersebut akan sulit dilakukan dalam keadaan tidak pasti. Mereka tidak tahu bagaimana memperkirakan dan merencanakan masa depan mereka. Hal ini dipersulit lagi dengan tidak adanya mekanisme yang dapat membantu para pemangku kepentingan untuk bekerja sama dalam mengatasi masalah serta belajar bersama dari tindakan dan keputusan mereka. Dalam keadaan seperti itulah para pemangku kepentingan memulai berbagai kegiatan pembelajaran ACM.

Peningkatan kondisi penghidupan merupakan kebutuhan utama para pemangku kepentingan di tingkat masyarakat, maka penilaian kami dalam bab ini difokuskan pada keluaran pembelajaran yang berhubungan dengan perubahan-perubahan penghidupan itu. Tetapi sebelum itu kita harus mengingat kembali apa yang telah dibahas dalam bab sebelumnya, yakni bahwa beberapa proses sosial telah terjadi antara para pemangku kepentingan, yang menghasilkan perubahan perilaku kerja sama dan perilaku adaptif mereka. Hal ini, pada gilirannya, menghasilkan

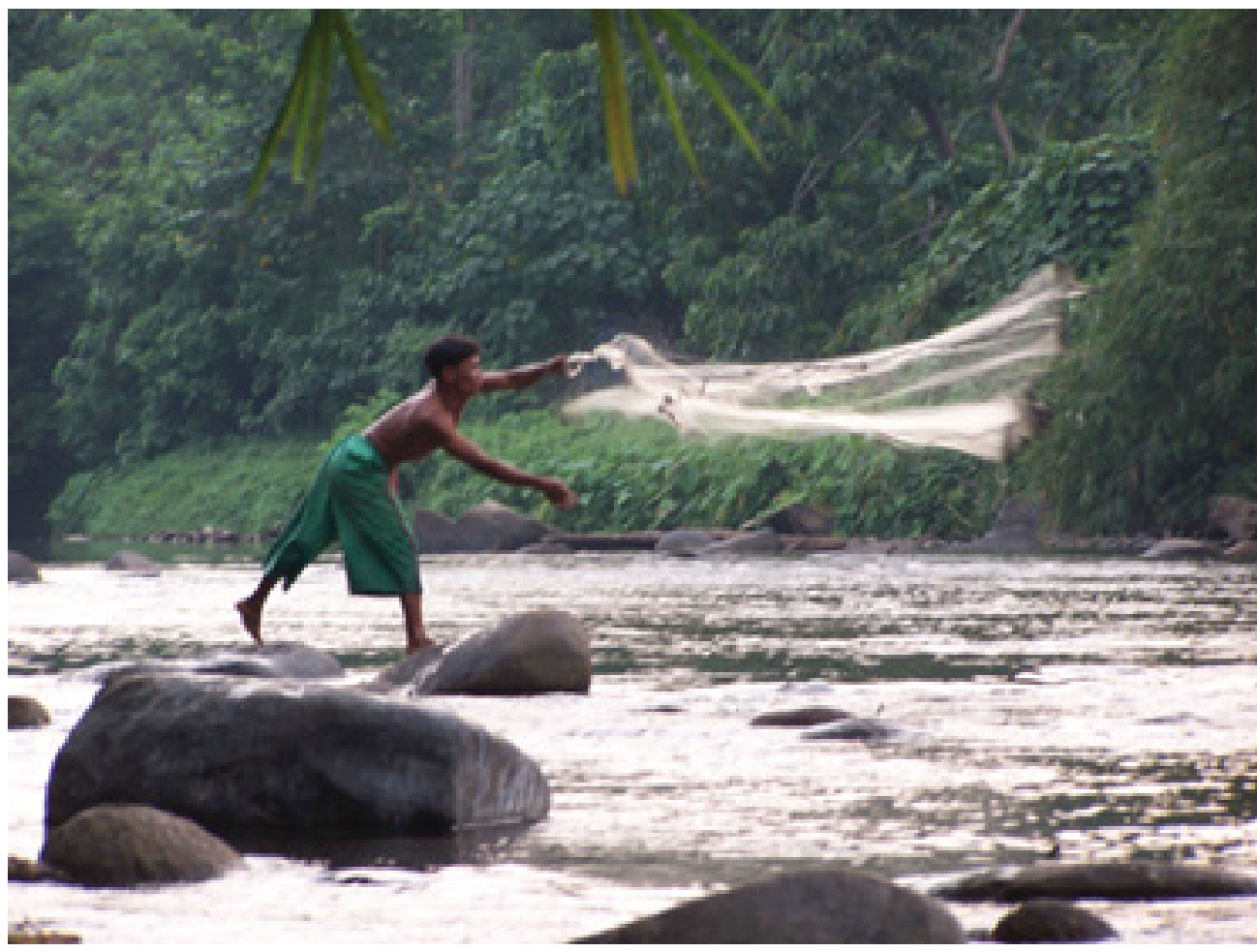

Hasil dari pembelajaran yang diinginkan para pemangku kepentingan lokal adalah peningkatan penghidupannya. Oleh karena itu, kami memfokuskan penilaian kami tentang hasil pembelajaran pada hal-hal yang berkaitan dengan perubahan-perubahan penghidupan. 
berbagai perubahan penghidupan masyarakat. Maka dari itu, proses-proses sosial yang muncul itu bisa kita sebut proses-proses perubahan. Proses-proses sosial apakah yang telah bermunculan?

\section{Proses-proses perubahan}

Seperti dapat dilihat pada bab sebelumnya, terdapat empat proses yang muncul dalam pembelajaran para pemangku kepentingan: pengembangan pengetahuan, pengembangan komunikasi dan hubungan, saling berbagi pengetahuan, dan pengembangan kapasitas strategis (atau kemampuan politis).

Proses-proses itu telah menghasilkan perubahan-perubahan perilaku para pemangku kepentingan, yakni diadopsinya cara berpikir dan bertindak yang baru. Lebih dari itu, proses-proses itu tidak hanya timbul sepanjang berjalannya pembelajaran, tetapi juga menjadi pemicu proses pembelajaran selanjutnya. Dengan demikian dapat kita bayangkan, proses-proses perubahan yang muncul itu berwujud "roda-roda berputar" seperti yang diperlihatkan Gambar 20. Dapat kita lihat pada gambar itu bagaimana pembelajaran sosial menggulirkan prosesproses perubahan yang mulai pada skala kecil tetapi kemudian "terpental" keluar untuk secara bertahap menjangkau wilayah yang lebih luas. Pertanyaan kita selanjutnya, perubahan-perubahan apakah yang telah dihasilkan proses-proses itu?

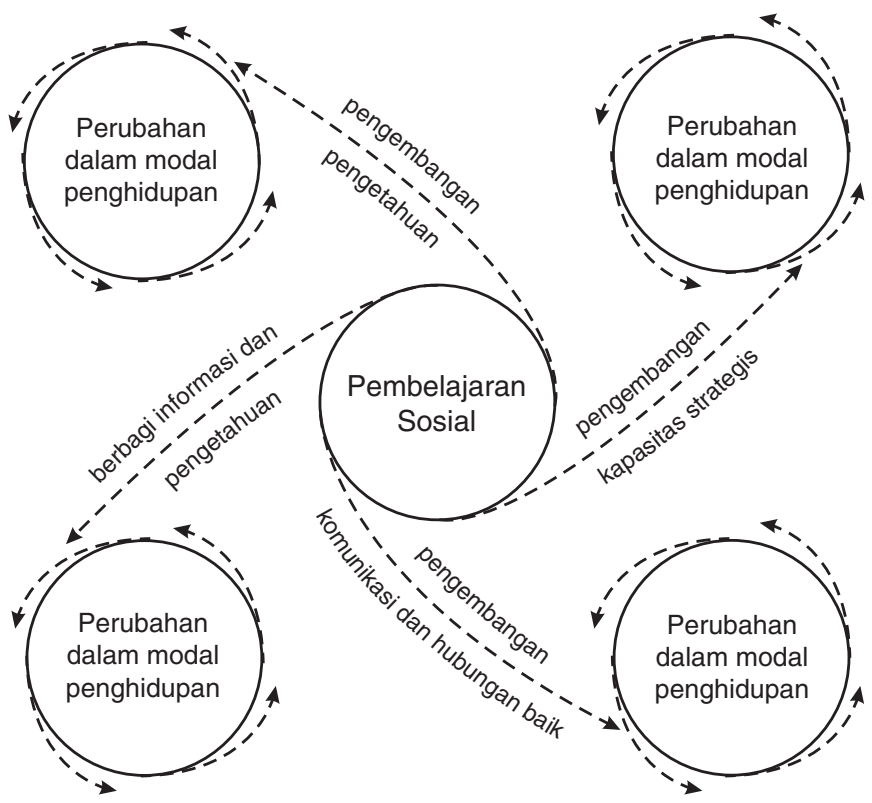

Gambar 20. Roda-roda perubahan karena pembelajaran sosial 


\section{Perubahan-perubahannya}

Untuk menentukan apakah pembelajaran telah menghasilkan perubahan dalam penghidupan masyarakat, kami sangat terbantu oleh sebuah alat bantu analisis yang disebut "kerangka penghidupan berkelanjutan" (sustainable livelihoods framework $)^{21}$. Kerangka ini menyatakan bahwa agar masyarakat dapat memiliki kehidupan yang layak mereka harus mendayagunakan sumber daya-atau asset/modal—yang memungkinkan mereka melakukan kegiatan penghidupan. Istilah "modal" yang dimaksudkan adalah unsur-unsur yang dibutuhkan dalam membuat penghidupan, jadi lebih luas daripada yang biasa digunakan dalam bidang keuangan atau ekonomi. Ada lima bentuk modal:

1. Modal manusia (human capital): pengetahuan, keterampilan, kondisi fisik pekerjaan, dan kesehatan

2. Modal sosial (social capital): saling percaya, jaringan-jaringan, dan hubunganhubungan sosial yang diperlukan orang untuk bekerja sama

3. Modal alam (natural capital): tanah, pepohonan, sumber daya air, ikan, dll.

4. Modal keuangan (financial capital): pendapatan, tabungan, dan pinjaman

5. Modal fisik (physical capital): peralatan, perlengkapan, binatang, jalan, dan pelayanan publik (air, tenaga listrik, dll.).

Dari pengamatan kami, sangat jelas bahwa sejak kami memulai pembelajaran ACM, modal manusia dan modal sosial yang dimiliki para pemangku kepentingan di kedua lokasi kajian mengalami perbaikan. Pertama, modal manusia jelas meningkat: keterampilan kepemimpinan berkembang, pengetahuan teknis dan keterampilan masyarakat semakin kaya, kemampuan berkomunikasi meningkat, kemampuan bernegosiasi mengalami kemajuan, dan motivasi perseorangan untuk bertindak guna mengatasi masalah terpacu. Kami juga mengamati bahwa
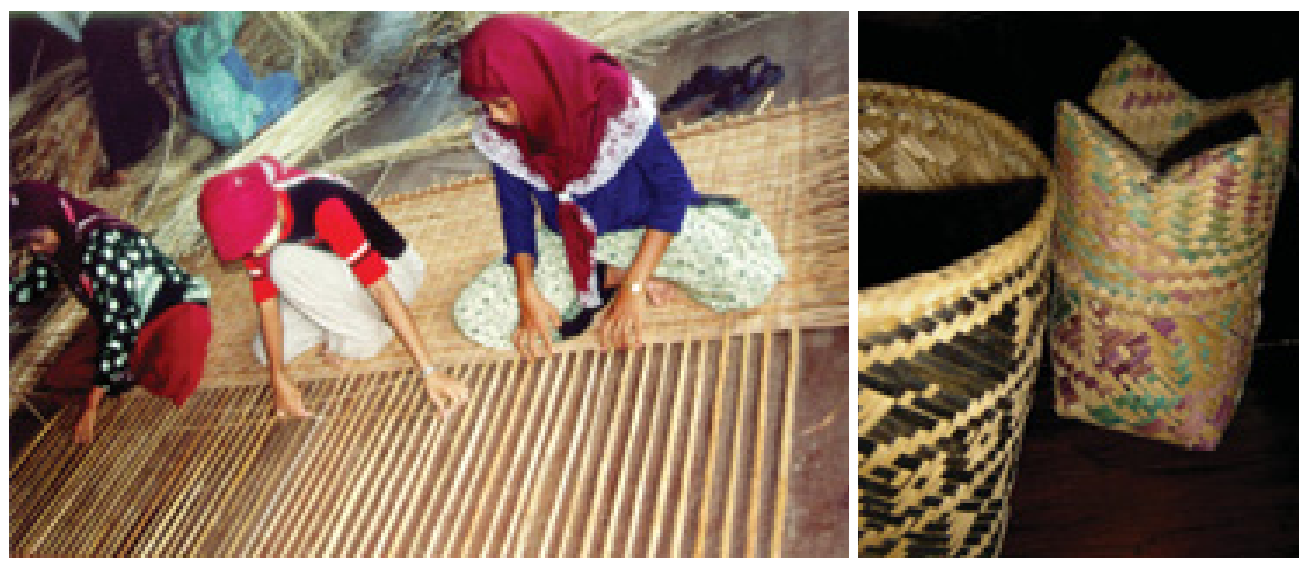

Di antara keluaran ACM yang lebih nyata adalah meningkatnya keterampilan masyarakat dalam memproduksi hasil anyaman rotan dan bambu, yang dapat dijual di pasar lokal. Keluaran ini terkait dengan pokok pembelajaran tentang peningkatan keadaan penghidupan dengan cara mencari sumber pendapatan alternatif (lihat Kotak 19). 
para pemangku kepentingan dari status sosial yang berbeda telah mengembangkan rasa percaya diri untuk memperbaiki hubungan di antara mereka.

Namun yang lebih nyata adalah perubahan-perubahan pada modal sosial. Rasa saling percaya di antara para pemangku kepentingan telah terbangun dan hal ini, pada gilirannya, memperbaiki hubungan dan menyeimbangkan perbedaan kekuasaan di antara mereka. Kualitas jaringan sosial yang sudah ada meningkat, dan jaringan-jaringan sosial baru terbentuk.

Perubahan-perubahan modal ini dipaparkan dalam Tabel 2 dan Tabel 3. Keluarankeluaran dalam kedua tabel tersebut berlaku untuk siklus-siklus pembelajaran yang telah kami gunakan sebagai contoh dalam bab sebelumnya, yakni siklus pembelajaran yang berkenaan dengan masalah tata batas dan siklus peningkatan pemerintahan desa (lihat hlm. 86 dan hlm. 87).

Tabel 2. Keluaran ACM dari pembelajaran tentang tata batas desa:

Contoh dari Pasir

Modal Penghidupan

Modal manusia

Modal sosial

Modal alam

Modal fisik

Modal keuangan

\section{Keluaran}

1. Berkembangnya keterampilan pemetaan warga masyarakat, termasuk penggunaan teknologi seperti GPS (misalnya, membaca, merekam, dan memasukkan data dari GPS ke peta dasar).

2. Berkembangnya pengetahuan masing-masing kelompok masyarakat (termasuk kaum perempuan dan remaja) tentang tata batas wilayah adat mereka.

3. Peningkatan pengetahuan kelompok-kelompok masyarakat tentang instansi pemerintah mana yang harus didekati dalam menyelesaikan permasalahan tertentu.

1. Komunikasi dan jaringan sosial antara masyarakat desa, perusahaan $\mathrm{HPH}$, dan pemerintah yang makin baik.

2. Kepercayaan antara masyarakat dan instansiinstansi luar yang meningkat.

Belum dapat diamati

Batas-batas desa

Belum dapat diamati 
Tabel 3. Keluaran ACM dari pembelajaran tentang peningkatan pemerintahan desa: Contoh dari Jambi

\section{Modal Penghidupan}

Modal manusia

Modal sosial

Modal alam

Modal fisik

Modal keuangan

\section{Keluaran}

1. Pemahaman yang berkembang tentang: kebijakan desentralisasi pemerintah dalam hal pengalihan kewenangan kepada desa (devolusi), prinsip-prinsip demokrasi (termasuk berkembangnya pemahaman ini pada para "penguasa" yang lama), mekanisme pengambilan keputusan tingkat desa oleh wakil-wakil pemangku kepentingan, pembuatan peraturan desa, dan kepemimpinan.

2. Berkembangnya keterampilan berkaitan dengan pengambilan keputusan, pengembangan peraturan desa, kepemimpinan, dan manajemen organisasi.

1. Kelembagaan sosial dan organisasi yang lebih baik:

a. mekanisme keterwakilan yang lebih baik;

b. keterwakilan para pemangku kepentingan masyarakat yang lebih baik.

2. Rasa saling percaya dan hubungan timbal balik yang lebih baik antara kaum pendatang dan penduduk asli; kesadaran kaum laki-laki bahwa kaum perempuan adalah warga masyarakat yang berpotensi dan sah untuk berpartisipasi dalam pengambilan keputusan tingkat desa; pengakuan tetua adat tentang perlunya membagi kekuasaan.

3. Kesadaran politik anggota masyarakat yang makin berkembang.

Belum dapat diamati

Belum dapat diamati

Beberapa anggota masyarakat telah memperoleh manfaat keuangan ketika mereka terpilih sebagai wakil-wakil masyarakat dan anggota BPD yang menerima gaji. 
Perubahan yang kurang nyata di kedua lokasi kajian tersebut adalah perubahan pada modal alam, modal keuangan, dan modal fisik. Kami menduga, terbentuknya bentuk-bentuk modal seperti itu memerlukan waktu yang cukup lama. Penelitian kami terlalu singkat sehingga perubahan dalam bentuk-bentuk modal itu belum dapat kami amati.

Walaupun demikian, kami menemukan beberapa petunjuk di lapangan tentang bagaimana dalam jangka panjang modal sosial dapat mempengaruhi pembentukan modal-modal yang lain, seperti modal alam dan modal finansial. Maka dari itu, modal sosial bisa dilihat sebagai "modal awal" (start-up capital) dan modal alam serta modal finansial sebagai "modal terbentuk" (formed capital), seperti dapat dilihat pada Gambar 21. Di sinilah letaknya peran penting fasilitasi ACM.

\section{Berkembangnya strategi penghidupan kolaboratif}

Ketika suatu masyarakat dianugerahi dengan kekayaan berupa kelima macam modal penghidupan, hal itu tidak serta-merta berarti bahwa penghidupan para pemangku kepentingan dalam masyarakat itu terjamin secara berkelanjutan. Untuk memastikan agar berbagai modal penghidupan tersebut benar-benar menghasilkan keluaran-keluaran penghidupan yang nyata-pendapatan, kesejahteraan, kecukupan pangan, kekuatan dalam menghadapi goncangan sosial dan alam, dan penggunaan sumber daya alam yang keberlanjutanmasyarakat tersebut harus mempunyai strategi.

Para pemangku kepentingan di dalam masyarakat itu harus mempunyai sasaran dalam menentukan bagaimana mereka akan menggunakan modal-modal penghidupan mereka untuk mencapai penghidupan yang berkelanjutan. Sebagai contoh, para pemangku kepentingan masyarakat desa harus memilih apakah mereka akan menggunakan sumber daya keuangannya (modal finansial) untuk membeli benih dan mengalokasikan keterampilan manusia (modal manusia) untuk bertani, ataupun mereka akan memilih untuk menyimpan uangnya di bank dan bekerja sebagai buruh di ibu kota kabupaten.

ACM meningkatkan jumlah pilihan penghidupan bagi para pemangku kepentingan. Dengan berkontribusi terhadap pengembangan modal sosial, ACM menawarkan sebuah strategi penghidupan melalui kolaborasi yang dapat digunakan para pemangku kepentingan untuk meningkatkan prospek penghidupan mereka.

Kebanyakan program pembangunan yang berfokus pada peningkatan penghidupan masyarakat, termasuk program-program hutan kemasyarakatan atau perhutanan sosial (lihat Bab 3), cenderung bertujuan untuk meningkatkan pendapatan. Akan tetapi pendekatan ACM dapat menawarkan lebih dari itu. 

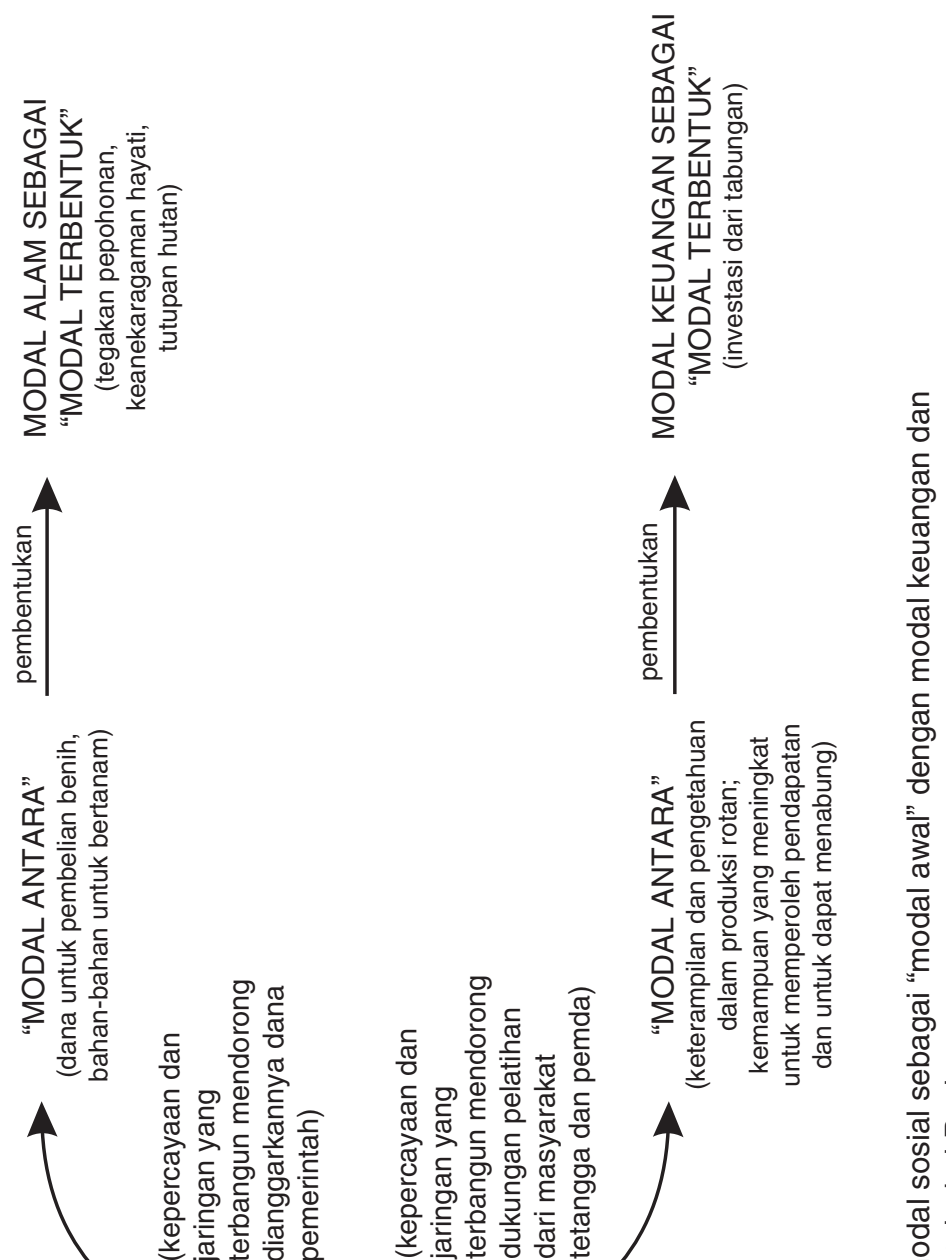

당 일 ส สิ

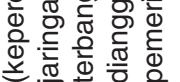

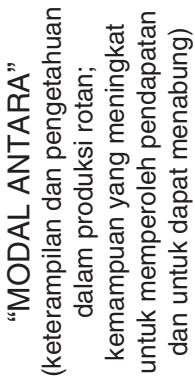

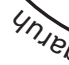

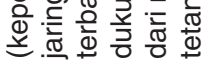
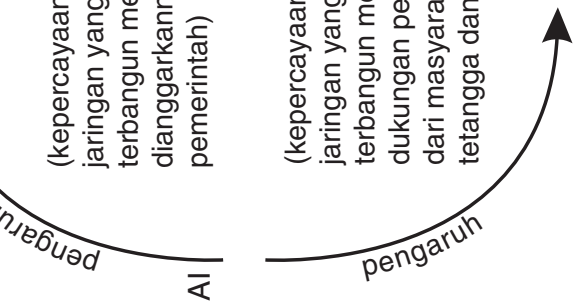

ग্ত

৫্র

岃:

心岩要

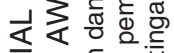

का

क穴

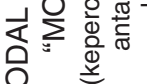

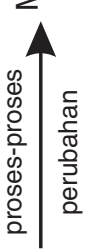

实

党

동

홍 온

ह $\frac{\mathrm{T}}{\mathrm{C}}$

ชิ

赵

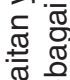

『ు

㐫 $\frac{E}{\frac{\pi}{\pi}}$

焉是 


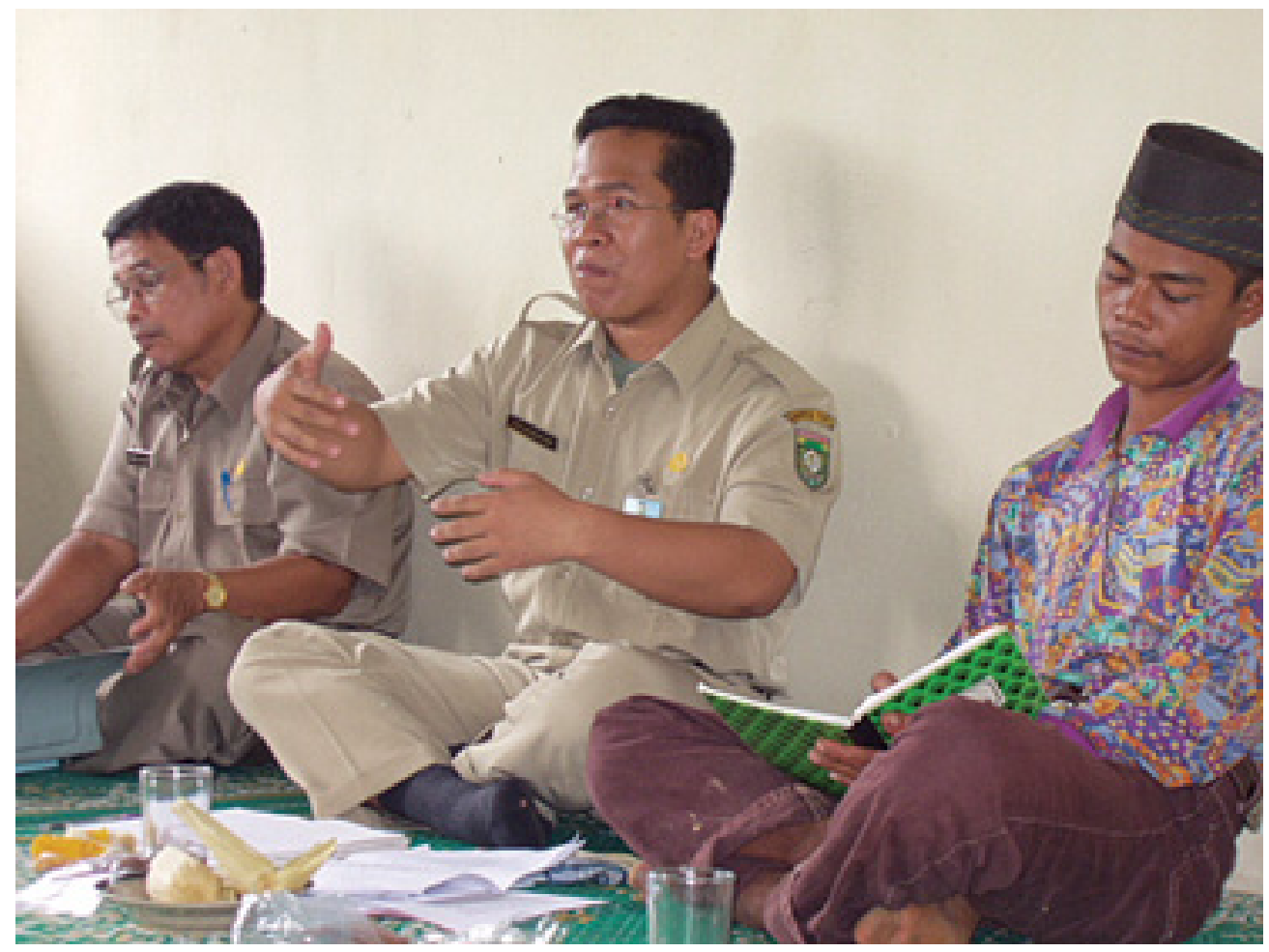

ACM telah meningkatkan modal sosial di antara para pemangku kepentingan.

Dengan cara menawarkan suatu strategi kolaboratif, ACM memperluas peluang penghidupan yang dapat digunakan para pemangku kepentingan. Dengan begitu, ACM memberi nilai tambah pada strategi penghidupan para pemangku kepentingan. Nampaknya, strategi penghidupan yang "terinspirasi ACM" dapat menghasilkan keluaran yang lebih luas: bukan saja peningkatan pendapatan, tetapi juga peningkatan kesejahteraan, kecukupan pangan, keberlanjutan sumber daya alam, dan pengurangan kerentanan (Gambar 22). 

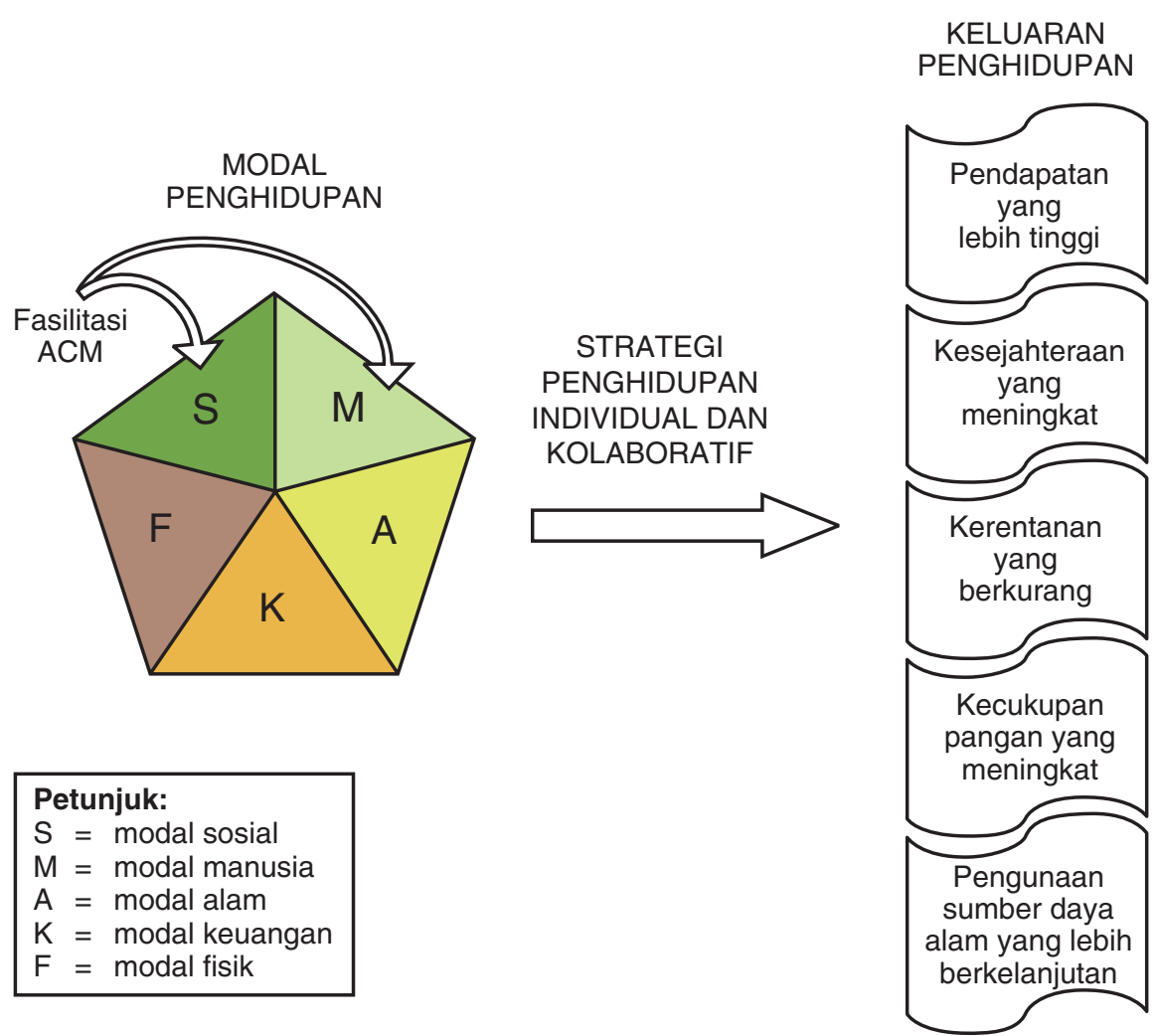

Gambar 22. Nilai tambah ACM terhadap strategi penghidupan 
6

\section{TANTANGAN, KEUNGGULAN, DAN KETERBATASAN ACM}

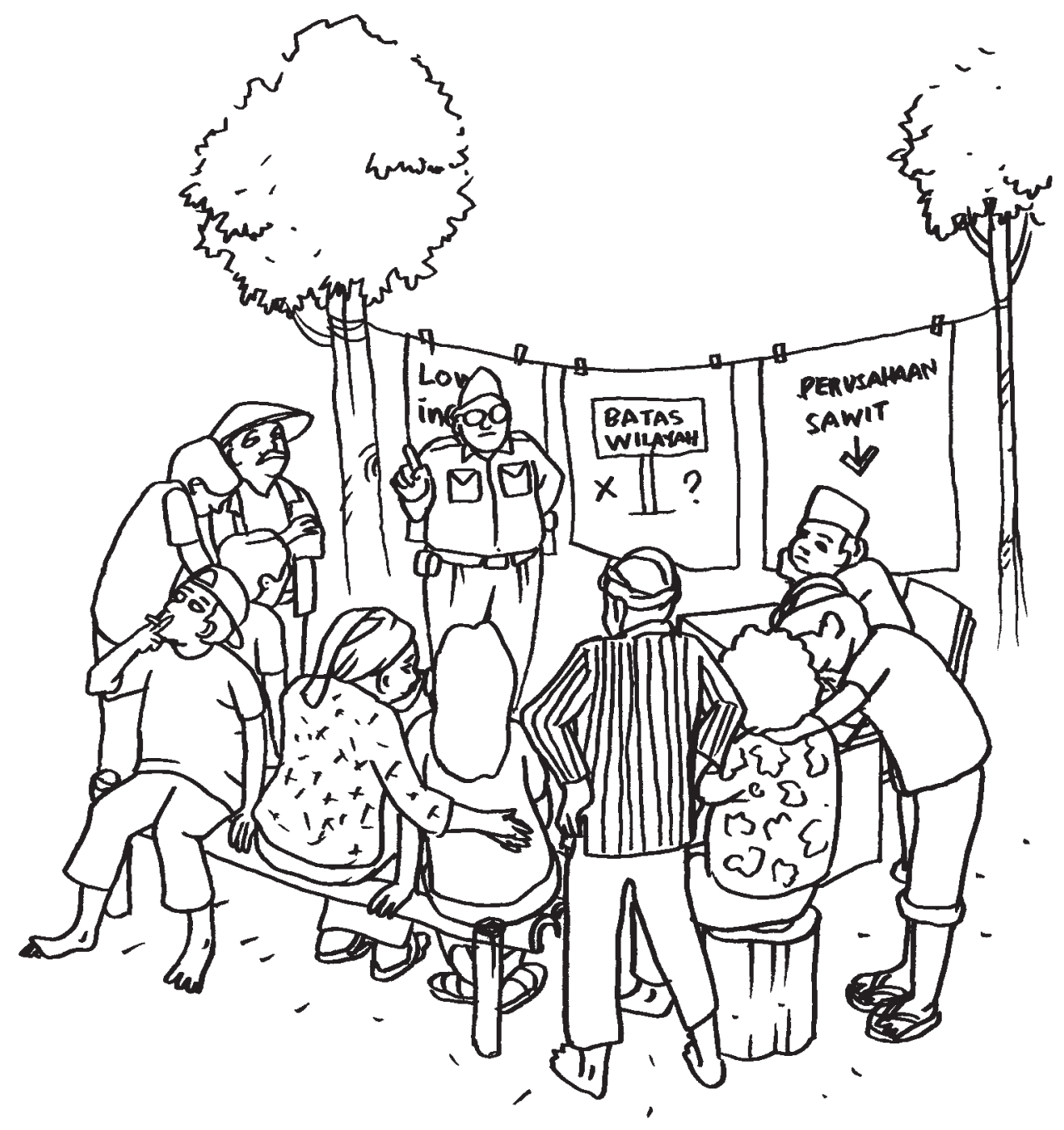




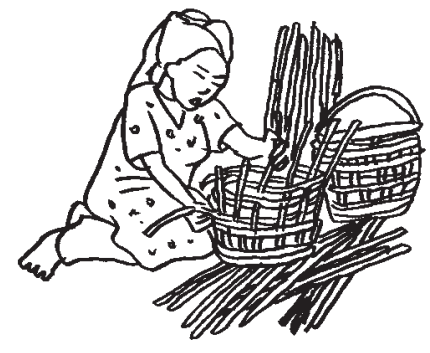

Surutlah engkau yang mesti surut, di geletar kepudaran fatamorgana tinggallah engkau yang mesti tinggal, di dirimu kebakaan metamorfosa.

Sri Kusdyantinah, penyair, dalam syair berjudul "Pancaroba", 1979 
Pada bab terdahulu telah kami sampaikan bagaimana kami menerapkan ACM dan menciptakan kondisi yang mendorong terjadinya pembelajaran antara para pemangku kepentingan. Bab ini menyajikan tantangan-tantangan yang dihadapi ACM, keunggulan-keunggulannya, serta keterbatasan-keterbatasan pendekatan ini sebagaimana kami menerapkannya.

\section{Tantangan}

Seperti juga banyak pihak lain yang bergiat dengan para pemangku kepentingan dalam mengelola sumber daya alam secara kolaboratif, kami menghadapi berbagai tantangan yang sudah umum dalam kegiatan-kegiatan yang menggunakan pendekatan partisipatif. Tantangan-tantangan semacam ini misalnya partisipasi masyarakat yang terbatas karena sibuk mencari nafkah untuk hidup kesehariannya atau ketergantungan mereka pada "orang luar". Namun demikian, kami melihat bahwa ACM memiliki empat tantangan yang merupakan ciri khas dari pendekatan ini:

1. Sementara ACM diharapkan dapat mengembangkan kerja sama antara para pemangku kepentingan, tantangan yang harus dihadapinya adalah sangat rendahnya kemampuan organisasional di antara para pemangku kepentingan. Kurangnya kemampuan organisasional ini menjadi tantangan ACM karena dua alasan. Pertama, ketika mengkaji masalah, para pemangku kepentingan cenderung melihat berbagai hal dari sudut pandang sempit mereka sendiri dan kurang menyadari bahwa suatu masalah dapat dilihat dengan cakupan yang lebih luas dengan juga memasukkan pandangan-pandangan pihak lain. Kedua, dalam memecahkan masalah mereka cenderung mencari pemecahannya sesuai dengan sudut pandangnya sendiri, tanpa memikirkan bahwa pemecahannya sebenarnya dapat dilakukan secara bersama dengan pihak lain. Pada umumnya pengidentifikasian dan pemecahan masalah secara kolaboratif belum banyak dikenal para pemangku kepentingan. Kalaupun ada pemangku kepentingan tertentu yang memiliki kemampuan kolaborasi di dalam kelompoknya sendiri, hal ini tidak berarti dengan sendirinya bahwa mereka bisa bekerja sama dengan pemangku kepentingan lain. Sering hal ini berhubungan dengan masa lalu. Di lokasi penelitian kami, misalnya, pada masa lalu para pemangku kepentingan tidak berkesempatan mengembangkan pengalaman mereka dalam berhubungan dengan pihak lain, seperti pemerintah dengan masyarakat desa di Pasir, ataupun penduduk asli dengan pendatang di Jambi.

2. Tantangan kedua yang kami hadapi, berkenaan dengan aspek pembelajaran, yang merupakan jiwa ACM. Kami tertantang oleh pertanyaan apakah para pemangku kepentingan akan cukup termotivasi untuk mempertahankan 
cara-cara baru dalam berpikir dan bertindak yang telah diadopsinya. Jika tidak, maka pembelajaran yang kami fasilitasi tidak akan berkelanjutan. Dalam sejarahnya, para pemangku kepentingan di lokasi penelitian kami hanya mengenal kegiatan-kegiatan belajar yang tidak menghasilkan perubahan yang langgeng. Misalnya, ketika baru memulai kegiatan di Jambi, kepada kami disampaikan bahwa penyuluh pertanian telah mengadakan pelatihan dalam penggunaan teknologi pertanian baru. Hanya dalam waktu singkat setelah pelatihan itu, warga masyarakat berhenti menggunakan teknik-teknik yang telah dipelajarinya. Penyuluh pertanian mengira hal ini dikarenakan masyarakat tidak mampu mempelajari dan mengadopsi teknologi baru, tetapi tim kami menduga hal tersebut dikarenakan teknologi tersebut dikembangkan di tempat lain dan hanya dialihkan ke lokasi. Dengan cara seperti ini alih pengetahuan tidak mengarah pada terjadinya pembelajaran yang benar-benar bermakna bagi pemangku-pemangku kepentingan lokal. Pada awal kegiatan tim kami, kami mengkhawatirkan hal yang sama dapat terjadi pada pembelajaran ACM.

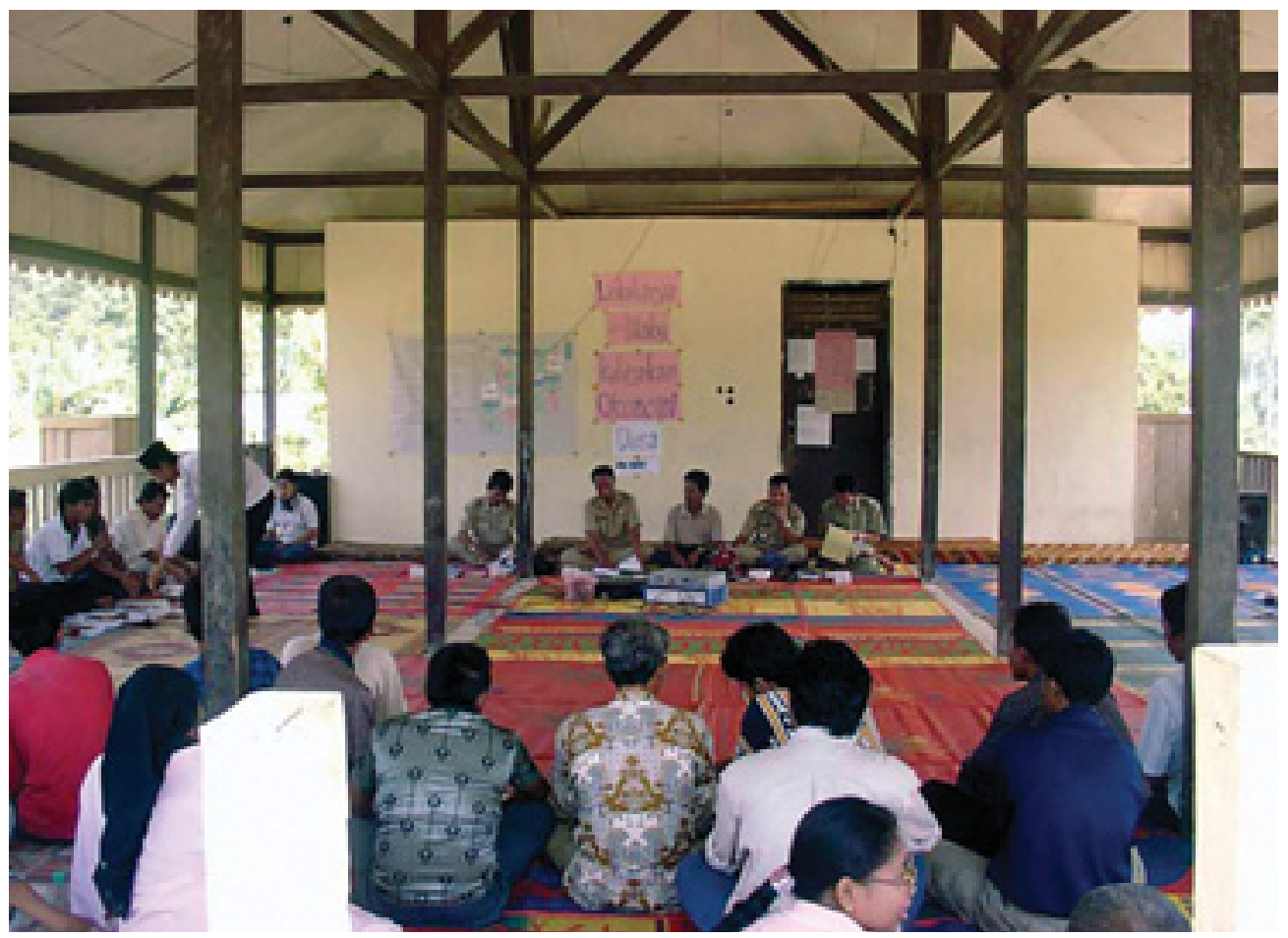

Perbedaan status sosial atau kekuasaan di antara para pemangku kepentingan merupakan salah satu tantangan yang dihadapi tim kami dalam memfasilitasi ACM. Gambar ini mencerminkan perbedaan status sosial antara masyarakat desa dan pejabat pemerintah. 
3. Lebih lanjut kami ditantang oleh pertanyaan apakah ACM akan berhasil dalam memotivasi para pemangku kepentingan untuk belajar di dalam lingkungan mereka yang begitu kompleks dan penuh ketidakpastian. Sebagaimana ditunjukkan pada masa lalu, perubahan lingkungan sosial dan alam dianggap begitu rumit sehingga para pemangku kepentingan terperangah dan merasa tidak berdaya untuk menghadapi perubahan itu. Kami dihadapkan oleh pertanyaan apakah pembelajaran dalam ACM dapat membantu mereka menghadapi secara kolaboratif keadaan semacam itu.

4. Tantangan terakhir yang kami hadapi ketika memfasilitasi ACM, berkenaan dengan perbedaan kekuasaan atau status sosial antara para pemangku kepentingan. Kami menemukan bahwa para pemangku kepentingan yang lebih berkuasa cenderung kurang terbuka untuk mempelajari cara-cara yang baru dan kolaboratif. Mereka sering beranggapan bahwa pihak dengan status sosial yang lebih rendah kurang layak atau tidak mempunyai legitimasi untuk diajak bekerja sama, atau bahkan untuk diajak berbicara atau didengarkan.

\section{Keunggulan ACM}

Sekarang kita akan membahas keunggulan ACM sebagaimana kami mengalaminya. Kami menyebut suatu kualitas ACM sebagai "keunggulan" jika hal tersebut memungkinkan kami untuk menangani tantangan-tantangan di atas secara berhasil. Tim kami memperhatikan bahwa keunggulan-keunggulan ACM adalah:

1. ACM memiliki kemampuan untuk menjadikan hubungan sosial antara para pemangku kepentingan lebih sistematis dan terorganisasi. Secara nyata kami melihat bahwa para pemangku kepentingan di kedua lokasi kajian mulai mengorganisasi diri mereka sendiri dengan lebih baik. Kami memperkirakan bahwa faktor yang telah mendorong terjadinya perbaikan organisasi sosial adalah sifat iteratif dari kegiatan pembelajaran ACM. Karena hal ini, interaksi dan komunikasi antara para pemangku kepentingan menjadi lebih intensif, yang pada gilirannya mendorong berkembangnya kesadaran akan ketergantungan timbal balik serta kesadaran untuk saling menghargai dan mempercayai. Kesadaran atas saling ketergantungan itu, pada gilirannya lagi, mendorong para pemangku kepentingan untuk mengakui pihak lain sebagai pemangku kepentingan yang sah (legitim) dalam sistem hutan yang sama. Kami melihat bahwa terbangunnya hubungan sosial yang lebih tertata tidak terbatas pada lingkup fasilitasi tim kami, tetapi terjadi juga di luar program kami. 


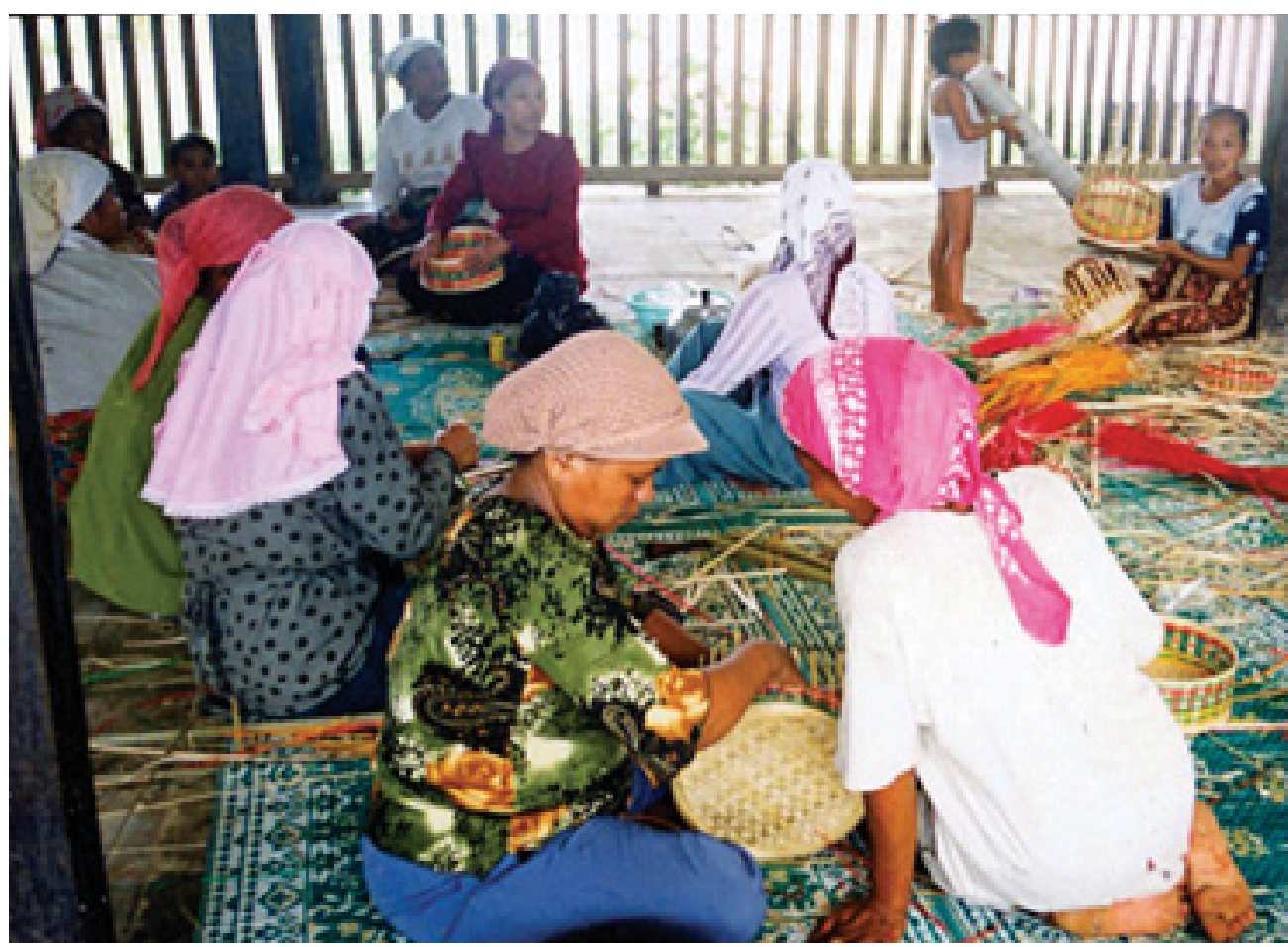

Tampaknya, salah satu keunggulan ACM adalah kemampuannya untuk menjadikan hubunganhubungan sosial lebih sistematis dan tertata. Kaum perempuan terbukti merupakan pemangku kepentingan yang terorganisasi paling baik, baik secara internal dalam kelompok mereka sendiri, maupun secara eksternal ketika berhubungan dengan para pemangku kepentingan lainnya.

2. Keunggulan ACM lainnya yang cukup terlihat, adalah kemampuannya untuk membantu para pemangku kepentingan dalam mengembangkan pemahaman mereka tentang fenomena yang rumit. Karena sifatnya yang bertahap, pembelajaran dalam ACM memungkinkan penguraian "bahan belajar" yang rumit menjadi bagian-bagian yang lebih "kecil dan sederhana". Hal ini memungkinkan para pemangku kepentingan untuk secara bersama dan bertahap memahami kontradiksi-kontradiksi yang mereka hadapi. Pada gilirannya, hal tersebut membantu mereka untuk secara berangsur memahami kerumitan yang ada.

3. Supaya dalam keadaan yang rumit dan penuh ketidakpastian pembelajaran dapat terjadi, suatu jenis pembelajaran yang khas ACM nampaknya menjadi kunci, yakni pembelajaran melalui komunikasi. Pembelajaran semacam ini mendukung berkembangnya pemahaman bersama para pemangku kepentingan dengan berbagai sudut pandang.

4. Kemampuan ACM untuk menangani masalah ketimpangan kekuasaan antara pemangku kepentingan mendorong mereka yang berkuasa untuk mengakui mereka yang lemah karena penekanannya pada: 
- peningkatan kesadaran tentang ketergantungan timbal balik, yang pada gilirannya mendorong para pemangku kepentingan untuk lebih saling menghargai

- manfaat yang dibawa masing-masing pemangku kepentingan ke dalam proses kolaboratif

- pembahasan substansi dan bukannya persoalan-persoalan hubungan sosial antara para pemangku kepentingan.

\section{Keterbatasan ACM}

ACM juga memiliki keterbatasan. Ada tiga keterbatasan yang kami lihat dengan jelas di lapangan:

1. Kegiatan belajar ACM sering sangat menyita waktu. Kegiatan pembelajaran, seperti lokakarya atau pertemuan para pemangku kepentingan, biasanya membutuhkan paling tidak satu hari penuh, selain menuntut waktu semua pihak yang terlibat dalam persiapan dan penyelenggaraannya. Artinya, ACM sering lebih menarik bagi mereka yang dapat meluangkan waktunya untuk berpartisipasi. Sebaliknya, para pemangku kepentingan yang kurang mampu sering lebih terbatas kesempatannya untuk berpartisipasi. ACM merupakan proses pembelajaran dan karenanya menuntut waktu. Keluaran dari proses pembelajaran ini tidak selalu cepat atau nyata. Ini merupakan keluhan umum yang kami dengar dari para pemangku kepentingan. Ironinya, sementara pemangku-pemangku kepentingan yang terkesampingkan secara sosial sangat membutuhkannya, mereka justru paling sedikit menerima manfaat dari ACM.

2. Bagi tim kami, pelaksanaan ACM juga menuntut banyak upaya dan waktu. Juga biaya untuk mempertemukan para pemangku kepentingan tidaklah sedikit. Selain itu, waktu dan sumber daya lain yang diinvestasikan sering tidak segera menunjukkan hasil. Hal in juga menjelaskan kenapa kami belum dapat memastikan apakah para pemangku kepentingan akan mempertahankan cara-cara baru mereka dalam berpikir dan bertindak. Walaupun begitu, kami yakin bahwa jika pembelajaran bersama dapat didorong secara terus-menerus, hubungan-hubungan konstruktif di antara para pemangku kepentingan akan terbentuk dan, pada gilirannya, sikap dan pandangan lama secara berangsur ditanggalkan.

3. Terakhir, ketika kekuasaan antara para pemangku kepentingan sangat timpang, kami melihat bahwa pembelajaran tidak mendorong berkembangnya pandangan yang lebih inklusif pada para pemegang kuasa. Nampaknya, keadaan dengan ketimpangan kekuasaan yang sangat menonjol bukan 
merupakan kondisi yang tepat untuk saling belajar. Dalam kondisi seperti itu sulit diharapkan terjadinya suatu transformasi pandangan dan perilaku lama.

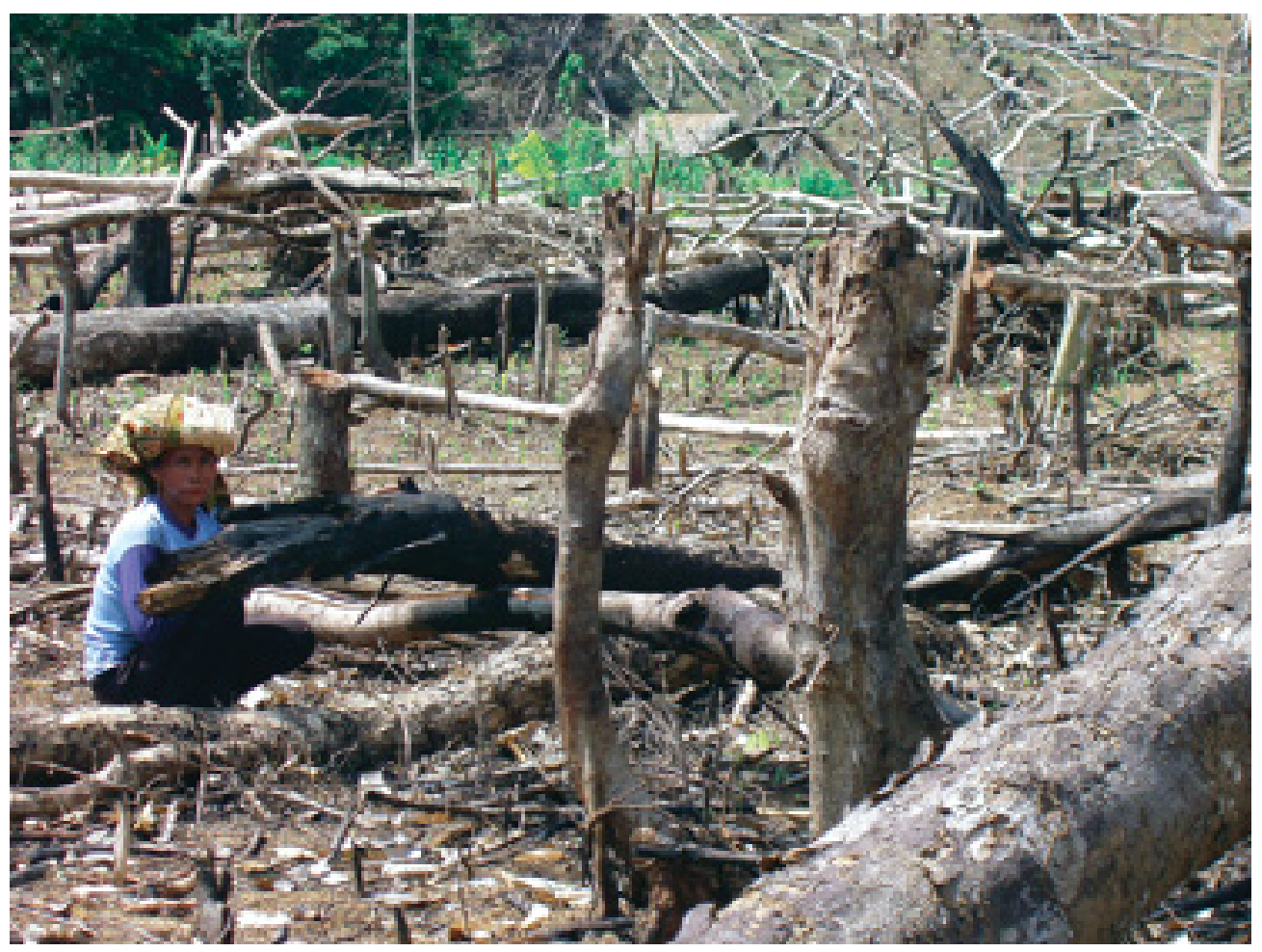

Salah satu keterbatasan ACM seperti yang kami alami adalah bahwa kegiatan-kegiatan belajar sangat menyita waktu, baik bagi para peserta maupun bagi tim kami. Sering ini berarti bahwa ACM menjadi kurang menarik bagi para pemangku kepentingan yang lebih miskin karena mereka mengalami kesulitan dalam menyediakan waktu untuk kegiatan pembelajaran. 


\section{HIKMAH BELAJAR}

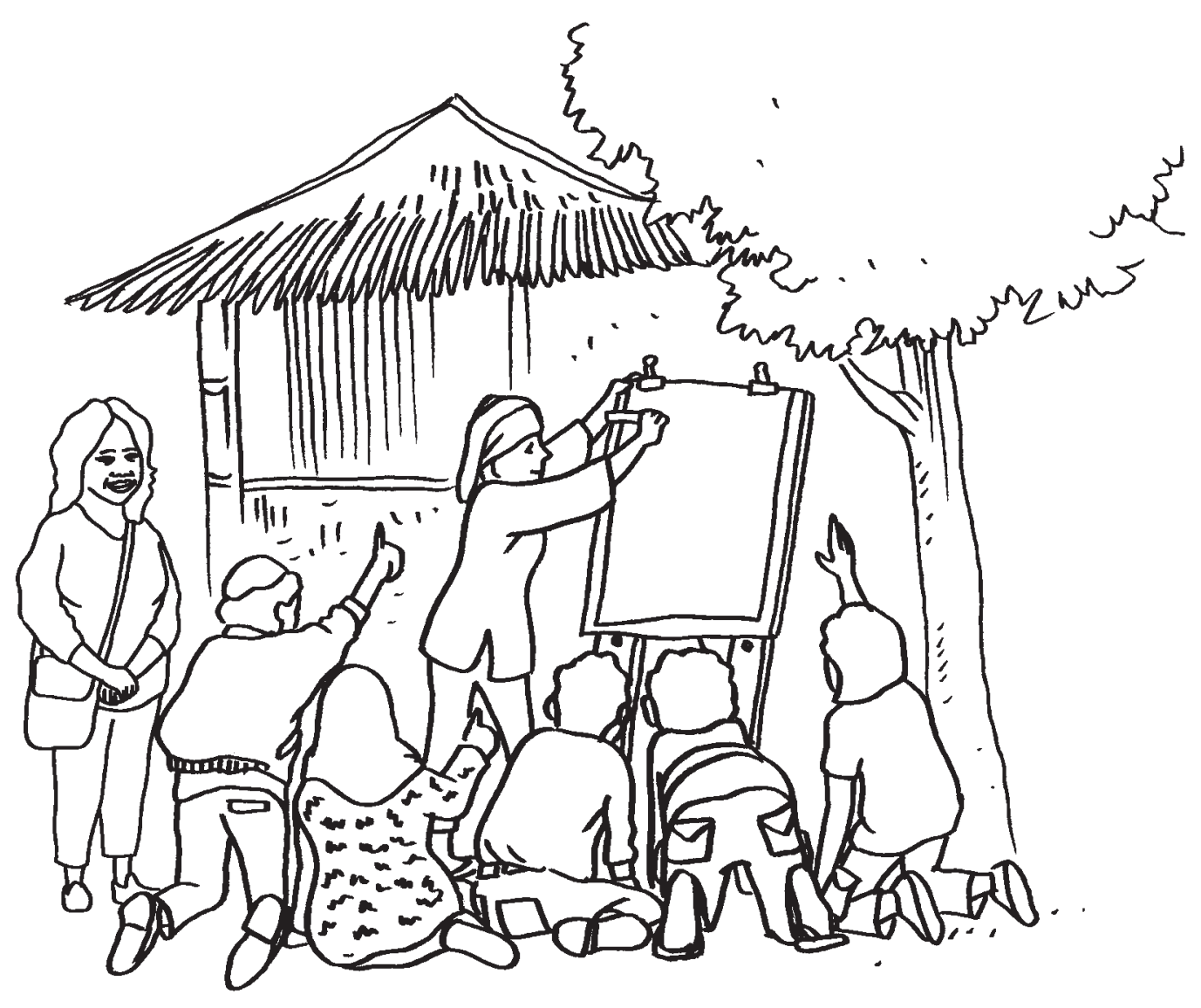


.. jika kita harus membangun kembali keselarasan sosial dan kebajikan .... Kita harus mendorong pertukaran sosial dan material antara sesama yang sederajat.

(... if we are to recover social harmony and virtue .... We must encourage social and material exchange among equals.)

Matt Ridley, ahli zoologi dan penulis tentang ilmu pengetahuan, dalam "The Origins of Virtue", 1997 
Mengetahui keunggulan dan keterbatasan-keterbatasan ACM serta tantangantantangan dalam penerapannya, memungkinkan kami untuk menarik beberapa pelajaran. ACM merupakan suatu pendekatan yang memperoleh wujudnya sepanjang penerapannya di lapangan. Pelajaran-pelajaran yang kami sampaikan berikut ini muncul sepanjang proses tersebut. Beberapa aspek dari pelajaranpelajaran berikut telah didiskusikan dengan lebih rinci pada bagian-bagian terdahulu.

1. Dari proses penelitian, kami belajar bahwa ACM dapat membantu para pemangku kepentingan untuk mengorganisasi dirinya guna menjalin hubungan dan berkolaborasi di antara mereka. Meskipun pemangku kepentingan tertentu mungkin sudah memiliki kemampuan berorganisasi dan bekerja sama di dalam kelompoknya sendiri, bisa jadi mereka kurang mampu untuk saling berhubungan dan berkolaborasi dengan pihak-pihak lain. Ini terjadi di lokasi-lokasi penelitian kami karena di masa lalu para pemangku kepentingan kurang berkesempatan dalam mengembangkan hubungan di antara mereka. Dalam kurun waktu kurang dari dua tahun, pengorganisasian kelompok-kelompok pemangku kepentingan meningkat. Pada gilirannya hal ini meningkatkan mutu proses pengambilan keputusan bersama.

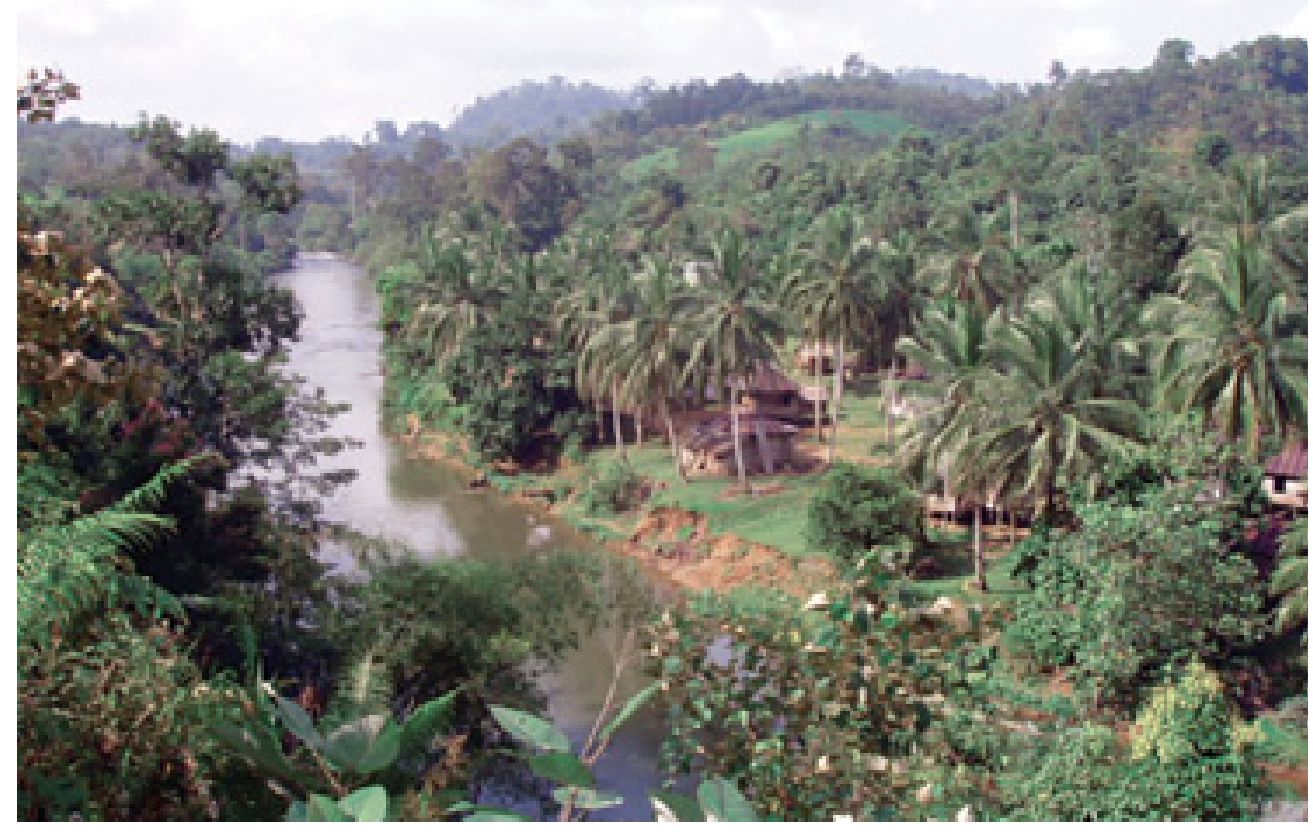

Seiring dengan perjalanan penelitian aksi, tim kami belajar bagaimana ACM mempengaruhi hutan dan para pemangku kepentingan. 
2. Seperti telah dicatat di atas, ACM sangat membantu dalam mendorong para pemangku kepentingan untuk saling menjalin hubungan dan berorganisasi di antara mereka. Cara ACM melakukan hal ini adalah dengan mendorong pembelajaran yang iteratif. Dalam siklus penelitian aksi partisipatif, langkah yang berulang-ulang itu mendukung pembelajaran semacam ini. Keempat prinsip yang digunakan ACM dalam mengorganisasikan pembelajaran bersama bagi para pemangku kepentingan adalah: kepemilikan para pemangku kepentingan atas proses pembelajarannya, keterwakilan semua pemangku kepentingan, pembelajaran berdasarkan pengalaman, dan pembelajaran melalui komunikasi.

3. Pelajaran ketiga berkenaan dengan perbedaan kekuasaan di antara para pemangku kepentingan. Sebagai orang luar, kita sering tidak melihat adanya ketimpangan kekuasaan antara para pemangku kepentingan. Ketika memasuki lokasi terpencil, mungkin nampaknya para pemangku kepentingan lokal hidup dengan damai dan harmonis dan tidak ada permainan kekuatan di antara mereka. Kita cenderung berpikir bahwa politik hanya berperan di ibu kota, wilayah perkotaan, atau di DPRD. Namun walaupun tidak selalu tampak di permukaan, perbedaan-perbedaan yang menyebabkan konflik ada di mana-mana, termasuk di masyarakat dan kelompok-kelompok lokal. Kita mungkin tidak melihat ketimpangan-ketimpangan yang ada karena para pemangku kepentingan yang lemah cenderung diam atau kita kurang dapat "mendengar suara mereka". Bisa juga masyarakat berpura-pura tidak ada perbedaan pendapat atau konflik di antara mereka. Sebagai orang luar bisa jadi kita tidak mempunyai "alat untuk mendengarkan" pihak yang "tidak bersuara". ACM telah sangat membantu tim kami, sebagai orang luar, untuk lebih peka terhadap perbedaan-perbedaan kekuasaan antara para pemangku kepentingan. ACM dapat membuat perbedaan semacam ini tampak lebih nyata dan pada saat yang sama memfasilitasi para pemangku kepentingan dalam menghadapinya. Situasi-situasi konflik dikendalikan (dikelola) melalui proses-proses sosial yang muncul di antara para pemangku kepentingan.

4. Seperti yang telah dipaparkan dalam Bab 6 kegiatan-kegiatan ACM sangat menyita waktu sehingga para pemangku kepentingan yang miskin kurang terlibat dan kurang memperoleh manfaat dari pembelajaran dalam ACM dibandingkan para pemangku kepentingan lainnya. Untuk menghindari hal ini, dalam upaya-upaya kita, pemangku-pemangku kepentingan yang miskin dan kurang berdaya perlu diberi perhatian yang sesuai sehingga mereka dapat memperoleh manfaat secara adil.

5. Keterbatasan yang lain adalah bahwa ketika perbedaan kekuasaan antara para pemangku kepentingan sangat timpang, pemangku-pemangku kepentingan yang lebih berkuasa ternyata tidak terdorong untuk belajar. 
Mereka cenderung mempertahankan perilaku kuno mereka dan kurang adaptif dalam mengadopsi cara-cara baru. Seorang fasilitator harus mencari cara-cara yang kreatif untuk mendorong para pemangku kepentingan ini agar lebih terbuka dan bersedia untuk belajar dari pihak-pihak lain.

6. Pelajaran terakhir berkenaan dengan nilai tambah ACM pada pengelolaan hutan di Indonesia. Dari pengalaman kami dalam menerapkan ACM, kami meyakini bahwa pendekatan ini menawarkan tiga nilai tambah bagi pengelolaan hutan:

a) ACM meningkatkan kemampuan para pemangku kepentingan untuk mengorganisasi di antara mereka untuk beraksi dan melakukan pemantauan bersama

b) ACM memacu para pemangku kepentingan untuk belajar secara sadar dan sistematis di antara mereka dan dari lingkungan alam untuk kemudian beradaptasi dengan perubahan-perubahan yang terjadi

c) ACM menyediakan cara pengelolaan hutan dimana fasilitasi (pembelajaran) dan pengkajian/penelitian berjalan seiring dan saling memperkuat satu dengan yang lainnya. 



\section{Bagian Empat \\ Implikasi dan Kesimpulan}

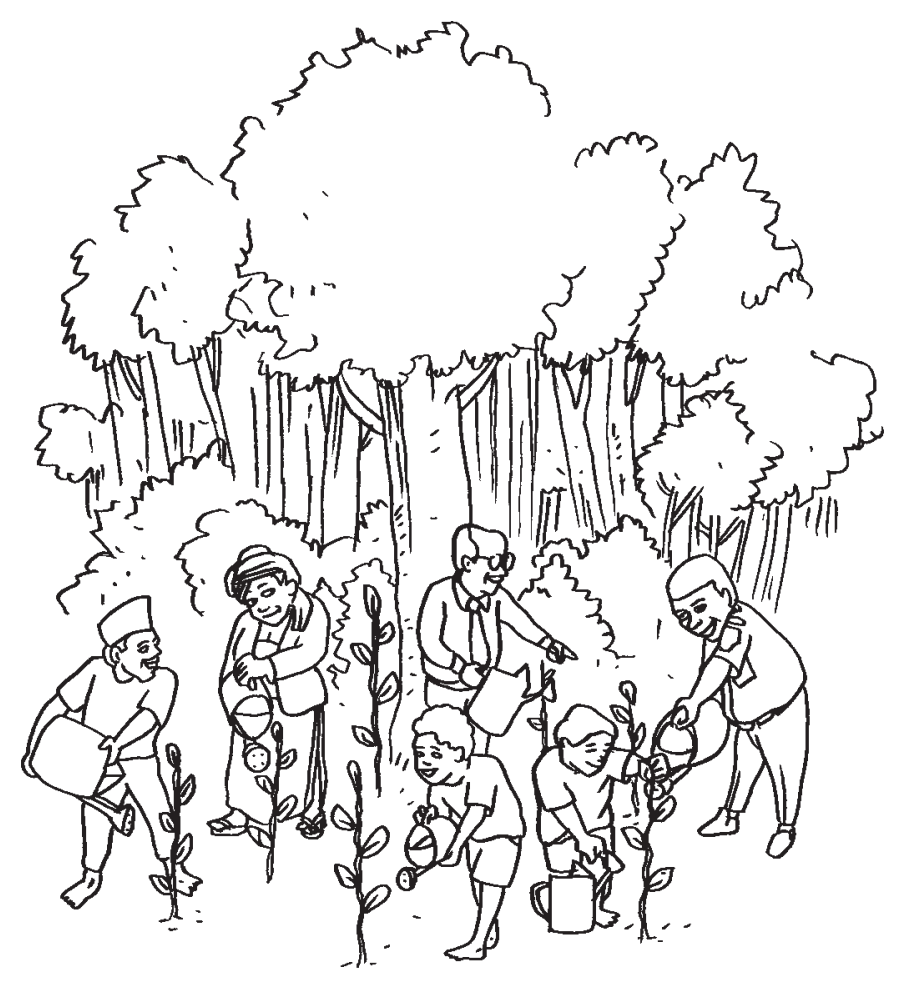

Didasarkan pada hikmah belajar dari penelitian ACM kami, Bagian Empat membahas implikasinya untuk pengelolaan hutan di Indonesia (Bab 8) dan menyajikan kesimpulan kami dari penelitian dan penerapan ACM (Bab 9). 

8

\section{MENERAPKAN ACM SECARA LUAS DALAM PENGELOLAAN HUTAN DI INDONESIA}

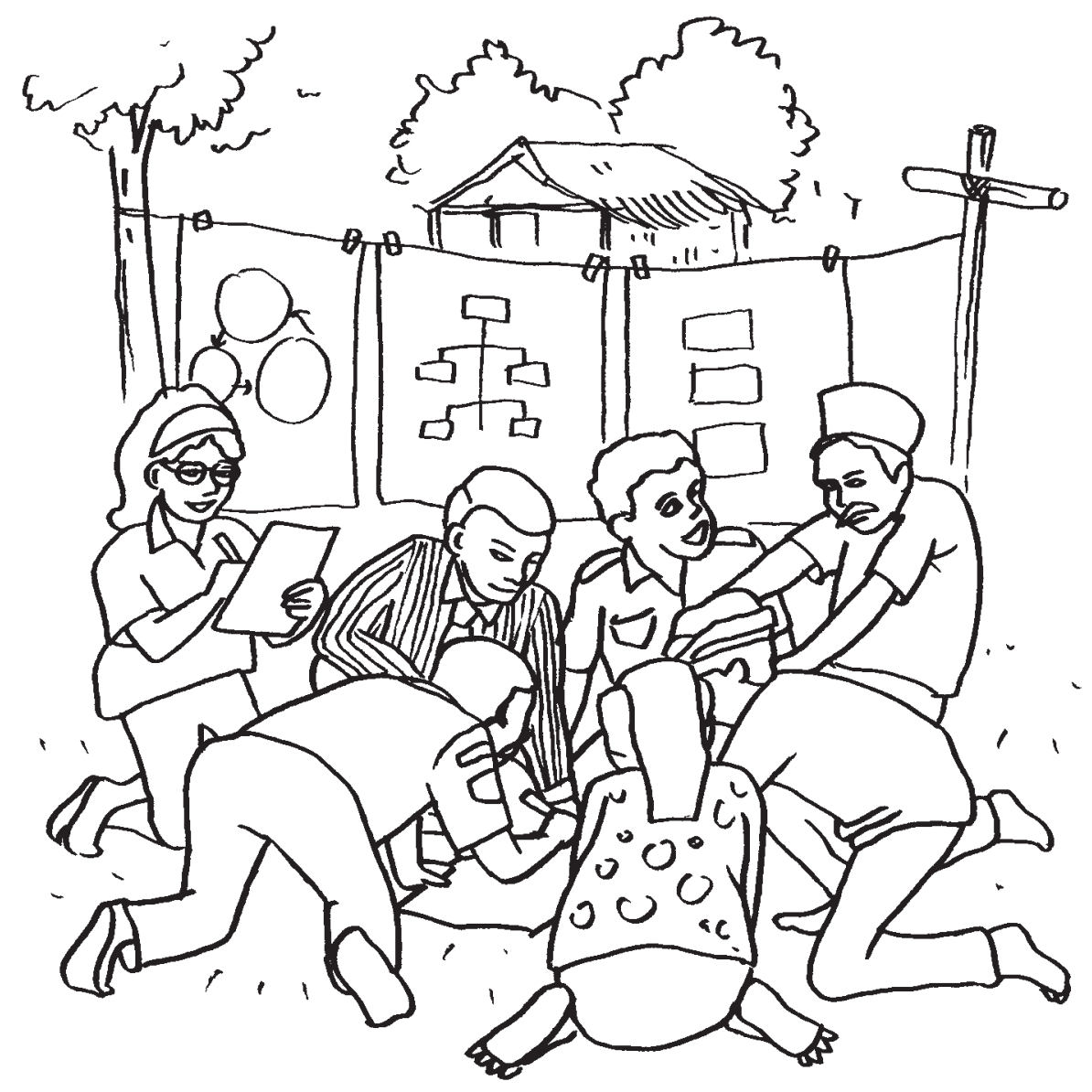


... prosesnya tidak berakhir dengan penciptaan pengetahuan baru. Harus ada juga komitmen untuk bertindak yang mengarah pada perilaku lingkungan dan sosial yang selaras dengan pembangunan berkelanjutan.

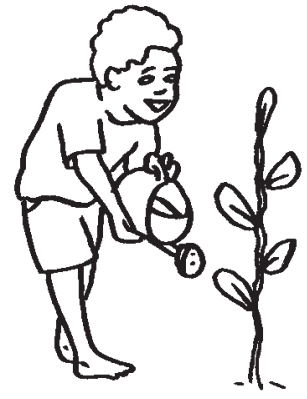

(... the process does not end in the creation of new knowledge.

There must also be commitment to action that leads to environmental and social conduct compatible with sustainable development.)

Cecilia von Sanden dan Graciela Evia dari Centro de Investigación y Promoción Franciscano y Ecológico (Uruguai) dalam "Environmental Learning", 1993 
Pelajaran-pelajaran yang diperoleh tim kami dari penerapan ACM di kedua lokasi di Indonesia berimplikasi bagi pengelolaan hutan di negeri ini. Bab ini memaparkan beberapa implikasi yang kami pandang penting.

\section{Mengapa Repot-Repot dengan Pembelajaran dalam Pengelolaan Hutan?}

Seperti yang disampaikan dalam Bab 3, pendekatan partisipatif telah berkembang melalui berbagai percobaan yang bersifat "uji dan ralat" (trial and error) namun yang pada kenyataannya berjalan lamban. Upaya-upaya pemerintah pada umumnya masih bersifat top-down dan terlalu berhati-hati dalam bereksperimen dengan pendekatan partisipatif. Upaya-upaya tersebut didasarkan pada kerangka pemikiran yang membatasi ruang untuk berpikir secara kreatif dan inovatif. Oleh karena itulah dibutuhkan pembelajaran yang dapat menggugat modelmodel mental seperti itu. Pembelajaran menawarkan sebuah opsi untuk mengembangkan pengelolaan hutan yang lebih baik, tetapi pembelajaran itu harus bisa menggugat kerangka-kerangka berpikir yang lama dan kaku.

Dari penelitian ACM, kami belajar bahwa pendekatan semacam ini dapat merupakan nilai tambah bagi program-program dan kebijakan kehutanan karena mempercepat proses pembelajaran dan mengaktifkan pengetahuan, yang kemudian ditransformasikan menjadi perubahan melalui aksi. Kondisi yang dapat memicu percepatan seperti itu dapat kita ciptakan.

Pertama, pembelajaran perlu diperluas agar mencakup pula para pelaku pengelolaan hutan serta melibatkan masyarakat dan kelompok-kelompok lokal, bukan hanya para petugas dan pejabat pemerintah, karyawan perusahaan, dan staf LSM. Selain itu, jaringan atau platform untuk pertukaran informasi dan pengetahuan yang dilakukan secara strategis dan terencana perlu dikembangkan. Terakhir, pentinglah pula untuk menghubungkan kegiatan-kegiatan berbagi pengetahuan dan informasi dengan aksi dan pengalaman nyata di lapangan.

\section{Berbagi Kerja antara Pemerintah, LSM, dan Lembaga Penelitian}

Persoalan-persoalan pengelolaan hutan saat ini terlalu kompleks dan tidak pasti dengan laju perubahan lingkungan alam dan sosial yang cepat untuk dihadapi oleh pemerintah sendiri. Berbagi tanggung jawab secara kemitraan antara pemerintah, LSM, dan lembaga penelitian akan lebih efektif karena masingmasing akan membawa pengetahuan, sumber daya, dan kapasitas lainnya ke dalam proses. 
Namun, dalam praktek ACM yang kami lakukan, kami melihat bahwa suatu kerja sama tidak akan menghasilkan sinergi, kecuali jika para mitra yang terlibat merumuskan sendiri hubungan kemitraan mereka. Oleh karena itu penting jika aturan main tentang kemitraan dikembangkan bersama oleh para mitra tanpa adanya tekanan dari pihak luar.

\section{Melibatkan Pemangku Kepentingan dalam Pengembangan dan Penerapan Kebijakan Kehutanan}

Berdasarkan pengalaman kami dalam melakukan penelitian aksi ACM bersama pemangku kepentingan, kami melihat bahwa identifikasi dan analisis pemangku kepentingan diperlukan untuk program kehutanan apa pun. Hal tersebut terutama diperlukan untuk menentukan sejauh mana kegiatan program mempengaruhi berbagai pemangku kepentingan dan, sebaliknya, bagaimana mereka dapat mempengaruhi berjalannya program tersebut. Meskipun demikian, mengidentifikasi dan menganalisis para pemangku kepentingan bukan sesuatu yang sederhana.

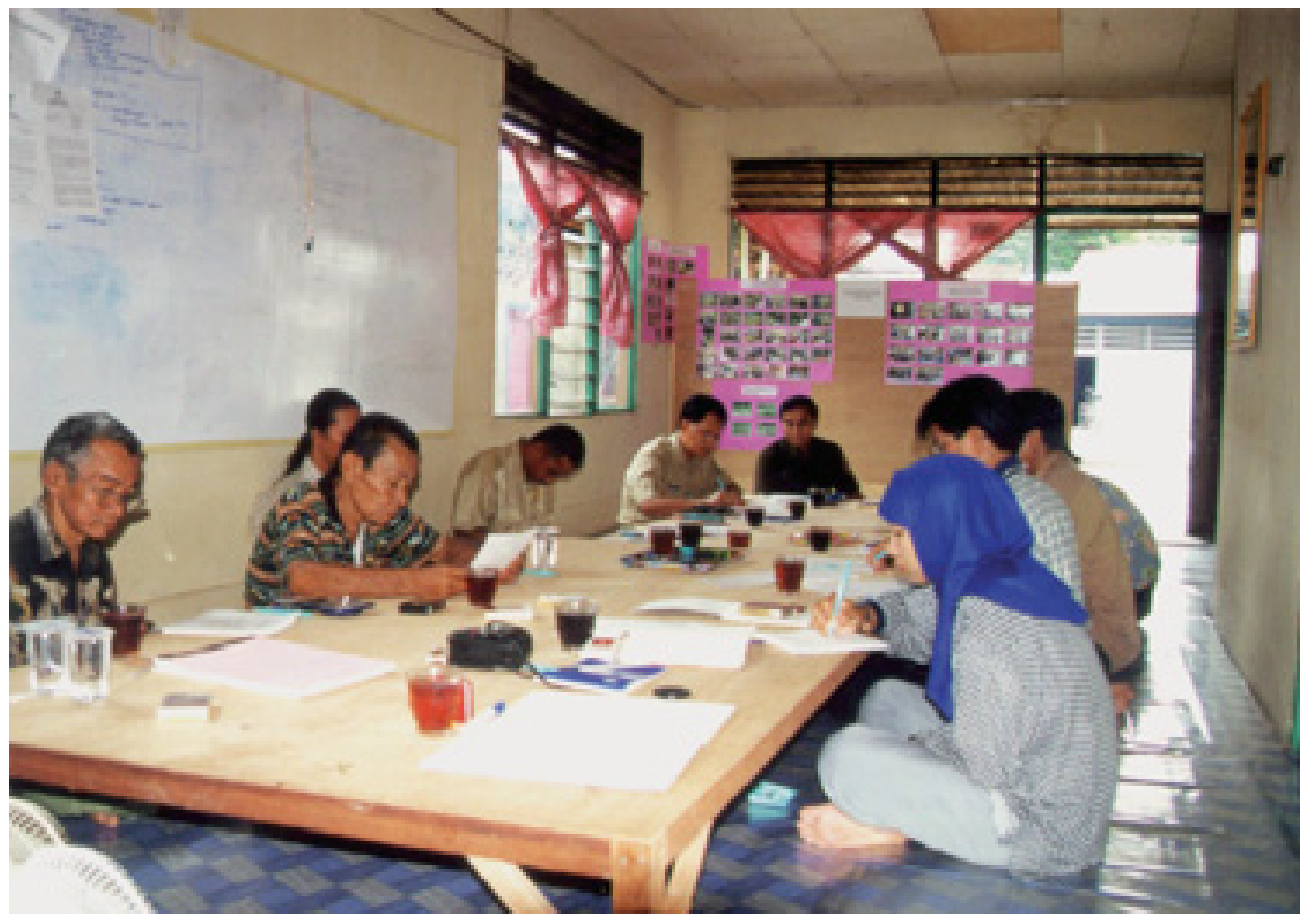

Penting bagi para perencana program dan staf kantor lainnya untuk secara teratur mengunjungi lapangan dan mengadakan pertemuan dengan para pemangku kepentingan lokal. Sebaiknya suatu rencana jangan hanya disusun dari belakang meja kantor. 
Sangatlah penting untuk melakukan identifikasi dan analisis pemangku kepentingan secara sistematis dan secara kritis. Proses ini harus diulang secara berkala sepanjang program. Analisis pemangku kepentingan harus dilakukan secara dinamis dan kreatif sehingga dapat mengembangkan kepekaan para pelaksana program terhadap permainan kekuasaan antara pemangku-pemangku kepentingan.

Untuk pelibatan para pemangku kepentingan dalam pembuatan kebijakan, konsultasi dan bentuk pelibatan mereka harus diintegrasikan dalam keseluruhan proses. Oleh karena keterbatasan waktu yang dimiliki pemangku-pemangku kepentingan lokal, kegiatan konsultasi harus diselenggarakan sesuai dengan kesibukan mereka sehari-hari. Kurang "tampaknya" kelompok-kelompok tertentu di dalam masyarakat, seperti perempuan atau kaum miskin, perlu mendapat perhatian khusus dalam menyelenggarakan konsultasi dan merencanakan program yang melibatkan mereka. Staf lapangan bisa ditugaskan untuk menjalin hubungan dengan mereka secara informal dan untuk berperan sebagai sumber informasi yang berharga untuk para perencana program. Namun demikian, untuk para perencana program tersebut, belajar dari lapangan tetaplah merupakan hal penting dalam melakukan tugasnya. "Dunia di luar sana" harus dipelajari-atau perlu dihadirkan lebih dekat—dan bukannya hanya direnungkan di kantor.

Dalam mengembangkan dan melaksanakan kebijakan kehutanan, mencari keseimbangan antara berbagai sasaran para pemangku kepentingan merupakan hal yang penting. Dalam prakteknya, keseimbangan tersebut dapat diraih secara bertahap. Misalnya, kita dapat mengadakan suatu pertemuan di antara para pemangku kepentingan untuk mendampingi mereka dalam menemukan dasar pijakan bersama. Pertemuan-pertemuan berikutnya dapat digunakan untuk, sedikit demi sedikit tapi dengan pasti, mengembangkan lebih lanjut dasar pijakan tersebut. Apabila sebuah dasar pijakan bersama sama sekali tidak dapat ditemukan, baru kita perlu mencari pihak yang dapat membantu untuk "campur tangan" dan memberi arahan.

Melibatkan para pemangku kepentingan dalam program kehutanan menyiratkan bahwa para pelaksana program harus mendorong terbentuknya hubungan yang konstruktif antara pemangku-pemangku kepentingan. Salah satu kondisi yang dapat membantu dalam hal ini adalah adanya mekanisme komunikasi untuk pertukaran informasi dan pengetahuan antara pemangku-pemangku kepentingan, seperti forum atau jaringan. Manakala hubungan-hubungan antara para pemangku kepentingan itu tumbuh dan berkembang, pada akhirnya dorongan dari luar tidak akan diperlukan lagi. Singkatnya, program-program kehutanan seharusnya berinvestasi untuk mengembangkan ruang-ruang komunikasi semacam itu. 


\section{Menuju Tujuan Jangka Panjang Sementara Bekerja dengan Sasaran Jangka Pendek}

Keluhan umum di antara para pelaksana program kehutanan adalah bahwa karena rencana program sering dibuat di kantor pusat, dalam pelaksanaannya sebuah program sulit disesuaikan. Perencanaan terpusat seperti itu sering masih dianggap tepat dan benar kendati kenyataan menunjukkan hal yang sebaliknya, yakni bahwa rencana program sering tidak cocok dengan keadaan nyata lokal. Di kalangan para perencana program, pelaksana, dan staf lapangan, pandangan bahwa rencana adalah sesuatu yang tuntas dan tidak dapat diubah lagi, masih sering kita temukan.

Dari penelitian aksi yang kami lakukan bersama para pemangku kepentingan, kami belajar bahwa sebenarnya sulit untuk membuat rencana program yang final, terutama karena tidak selalu jelas bagaimana tujuan jangka panjang dapat dicapai. Dalam membuat suatu rencana, akan lebih realistis jika kita melihat rencana itu sebagai sesuatu yang bersifat sementara. Penyesuaian rencana semula dapat dilakukan sepanjang waktu guna mengakomodasi berbagai perkembangan yang tidak terduga sebelumnya. Selama bumi berputar hal-hal tidak terduga akan selalu ada dan karenanya suatu rencana harus bersifat terbuka, sementara tetap terfokus pada tujuan jangka panjang. Untuk mempraktekkannya, misalnya, dalam suatu pertemuan para pemangku kepentingan membuat rencana konkret jangka pendek untuk suatu kegiatan, yang pada pertemuan berikut dapat dievaluasi. Hasil evaluasi kemudian dipakai untuk membuat rencana jangka pendek tahap berikut, namun dengan tetap tertuju pada tujuan jangka panjang. Proses ini diulang pada pertemuan berikut yang dapat digunakan para pemangku kepentingan guna mengevaluasi dan menyesuaikan rencana-rencana jangka pendek sesuai dengan kebutuhan yang muncul. Dalam memantau pelaksanaan rencana-rencananya secara kolaboratif di antara para pemangku kepentingan, daripada menggunakan aturan pemantauan yang kaku akan lebih membantu jika kita mengupayakan terbentuknya hubungan konstruktif di antara mereka. Membangun hubungan seperti itu dapat mendorong berkembangnya secara alami proses pemantauan yang dilakukan para pemangku kepentingan secara kolaboratif.

\section{Mengadopsi Pendekatan Proses dalam Program- Program Kehutanan}

Sebagian besar organisasi dan instansi yang memprakarsai dan melaksanakan program kehutanan mempunyai staf yang banyak tahu dan terampil dalam aspekaspek biofisik dan teknis kehutanan, tetapi cenderung kurang berpengalaman dalam mendorong proses-proses sosial di antara para pemangku kepentingan. Pada umumnya, program-program kehutanan kurang memperhatikan keluaran- 
keluaran proses-seperti kepercayaan antara para pemangku kepentingandibandingkan dengan keluaran-keluaran yang lebih nyata dan lebih mudah diukur-seperti jumlah bibit yang diperoleh dari kebun wanatani. Singkatnya, staf lapangan kehutanan pada umumnya kurang siap untuk memfasilitasi proses sosial.

Penelitian ACM kami menunjukkan bahwa kunci keberhasilan program kehutanan adalah proses. Hal ini terutama penting dalam pengembangan hubungan antara para pemangku kepentingan karena pada akhirnya hubunganhubungan itulah yang sangat mempengaruhi lingkungan alam dan sosial. Oleh karena itu, kami menyarankan agar perencana-perencana program kehutanan memasukkan dalam perencanaannya peningkatan kemampuan staf lapangan untuk dapat memfasilitasi proses, maupun menyertakan indikator-indikator proses untuk memantau pelaksanaan program.

Kami lebih lanjut menganjurkan agar birokrasi pemerintah mengembangkan mekanisme pemantauan yang tidak kaku. Staf lapangan perlu diberi ruang yang lebih luas untuk bergerak dengan lebih mandiri dalam menangani prosesproses yang berkembang di antara para pemangku kepentingan. Jika memiliki keleluasaan itu, staf lapangan akan lebih mampu mengakomodasikan kebutuhankebutuhan yang berkembang di antara para pemangku kepentingan.

Pengalaman kami selama penelitian menunjukkan bahwa siklus penelitian aksi partisipatif dapat membantu mengorganisasikan pembelajaran bagi para pemangku kepentingan dalam menempuh proses belajar mereka. Kami menyarankan proyek-proyek kehutanan menyelenggarakan kegiatan yang mengikuti siklus pembelajaran semacam ini.

\section{Fasilitasi Multipihak yang Efektif}

Mengingat kompleksitas lingkungan sosial dan alam yang dihadapi bidang kehutanan, program-program kehutanan harus dilengkapi dengan dasar yang kuat dalam hal memfasilitasi proses-proses multipihak secara efektif. Staf yang memadai untuk pekerjaan fasilitasi merupakan suatu keharusan karena para fasilitator inilah yang merupakan kunci keberhasilan program-program kehutanan. Oleh karena itu, suatu program kehutanan harus mengalokasikan dana yang memadai untuk pengembangan fasilitasi yang bermutu serta memberikan imbalan dan penghargaan lainnya yang memadai terhadap pekerjaan para fasilitator di lapangan.

Sifat penting yang harus dimiliki fasilitator multipihak adalah kepekaan terhadap perbedaan kekuasaan antara para pemangku kepentingan. Berbagai 


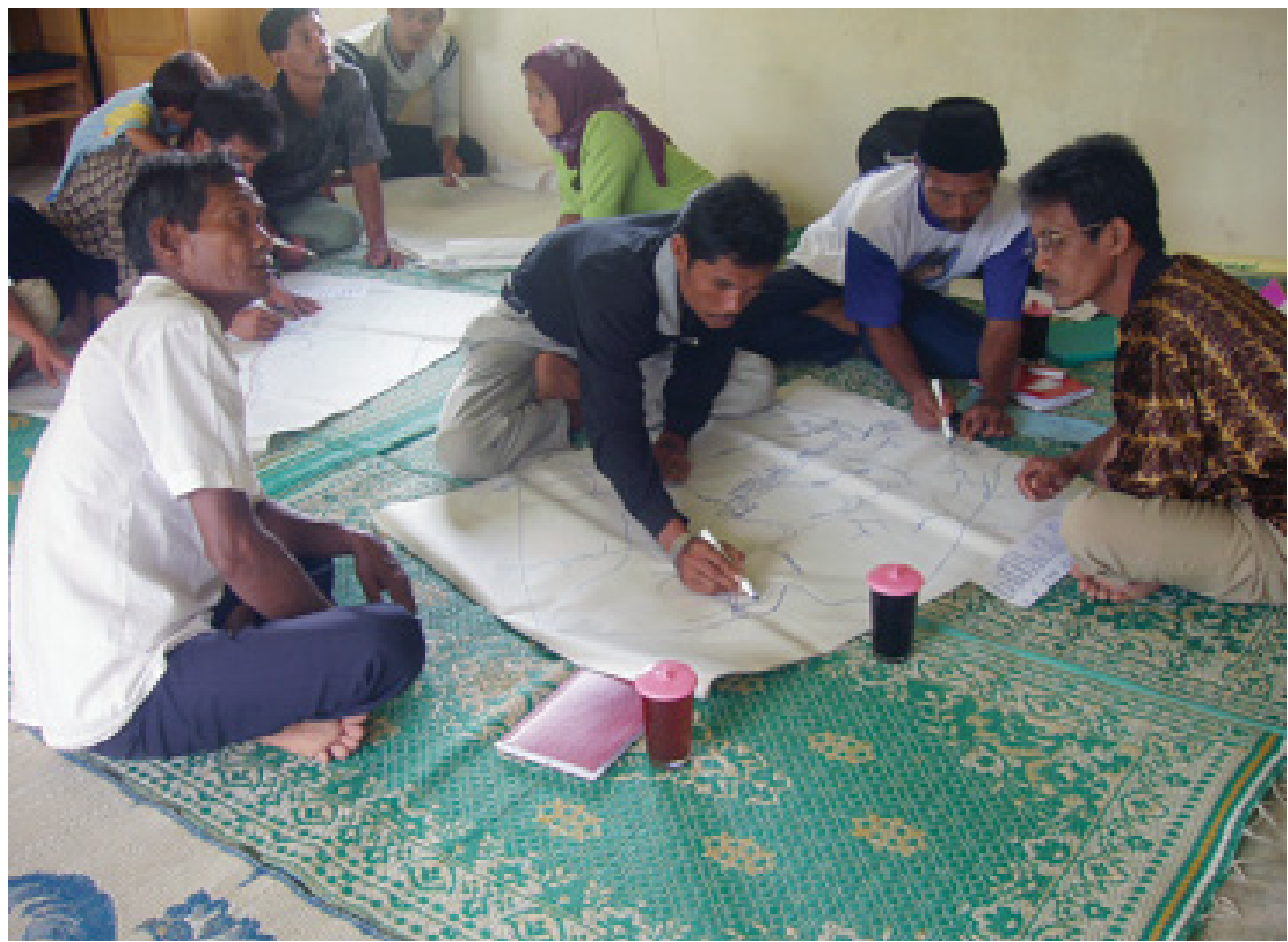

Fasilitasi yang bermutu adalah kunci keberhasilan.

alat dan metode dapat membantu para fasilitator dalam memfasilitasi proses, tetapi keterampilan para fasilitator berdasarkan kepekaan itu merupakan "alat fasilitasi" terpenting. Kepekaan semacam ini dapat dikembangkan seiring dengan berjalannya waktu dan meningkatnya pengalaman mereka.

Salah satu unsur kunci fasilitasi adalah mendorong arus komunikasi yang adil dan seimbang antara para pemangku kepentingan. Peran utama fasilitator adalah mendampingi multipihak dalam berkomunikasi. Untuk itu para fasilitator harus memiliki indikator-indikator tentang kepatutan, keseimbangan, dan keadilan dalam proses komunikasi antara para pemangku kepentingan. Jika terjadi ketimpangan dalam proses itu fasilitator harus mendampingi pihak-pihak yang kurang mempunyai kemampuan berkomunikasi untuk menyampaikan pandangannya.

Unsur kunci fasilitasi lainnya adalah mengembangkan proses pengambilan keputusan bersama. Pengalaman kami menunjukkan bahwa memfasilitasi proses pengambilan keputusan bersama benar-benar merupakan tantangan bagi para fasilitator. Sering ada kecenderungan para fasilitator untuk mendorong proses pengambilan keputusan ke arah yang sesuai dengan keinginannya. Oleh karena itu, para fasilitator multipihak yang efektif harus bisa menjadi pendengar yang baik, tidak hanya dengan telinganya, tetapi juga dengan hatinya. 
Dalam situasi konflik, sangat penting menyatakan dengan jelas bahwa fasilitator berposisi bebas dan tidak berpihak pada salah satu pihak yang berkonflik. Pada saat yang sama semua pihak harus mengetahui kepada siapa seorang fasilitator bertanggung jawab, misalnya, apakah ia bekerja untuk suatu LSM lokal, dinas kehutanan, atau suatu organisasi tingkat nasional. Hal ini akan mempermudah pihak-pihak yang difasilitasi untuk menilai posisi fasilitator dalam keseluruhan proses.

Beberapa unsur kunci dalam memediasi konflik pada program-program kehutanan adalah:

- Fasilitasi pengungkapan asumsi-asumsi agar menjadi lebih nyata dan jelas (eksplisit) sehingga tidak menghalangi komunikasi

- Tetapkan sebagai salah satu tujuan fasilitasi pembangunan hubungan yang konstruktif antara pihak-pihak yang berada dalam konflik

- Jelaskan kepada semua pihak apa yang menjadi tujuan-tujuan negosiasi sepanjang prosesnya: apakah mengembangkan pemahaman ("Mengapa kita lebih suka pilihan tertentu dari antara pilihan-pilihan yang ada?" "Bagaimanakah pilihan kita mempengaruhi pihak lain dan diri kita sendiri?"), ataukah memutuskan untuk memilih alternatif tertentu ("Apa yang akan kita lakukan?")

- Pastikan bahwa perundingan menjangkau semua kelompok-kelompok kepentingan dan tidak hanya melibatkan para wakil mereka. Ingatlah bahwa suatu sengketa biasanya melibatkan para anggota kelompok, bukan hanya para wakil atau pimpinan mereka.

\section{Dicari: Fasilitator yang Memiliki Komitmen!}

Mengingat tantangan-tantangan yang luar biasa dalam mengembangkan program-program kehutanan, fasilitator multipihak yang mempunyai komitmen sangat dibutuhkan. Kriteria penting untuk fasilitator seperti itu adalah:

- Kesediaan mereka bukan saja untuk melakukan tugasnya, tetapi juga untuk selalu belajar dan terbuka untuk mengadopsi pendekatan-pendekatan baru

- Kesediaan mereka untuk merefleksikan secara kritis kinerjanya

- Kesiapan mereka untuk menghadapi keadaan-keadaan yang sulit dalam bekerja dengan berbagai pihak.

\section{Ciptakan Ruang Pembelajaran dalam Organisasi Kita Sendiri}

Program-program kehutanan perlu dibangun atas dasar pembelajaran dan proses. Berdasarkan pengalaman kami, suatu organisasi yang menggerakkan pembelajaran, harus juga mempraktekkan pembelajaran di dalam organisasi 
itu sendiri. Lingkungan organisasional harus kondusif untuk memfasilitasi pembelajaran di luar "dinding-dinding" organisasi. Tentu akan sangat ironis jika kita berkhotbah tentang perlunya pembelajaran tetapi tidak mempraktekkannya sendiri.

Namun demikian, mengembangkan pembelajaran organisasional bukanlah suatu hal yang mudah. Sering staf dan departemen-departemen dalam organisasi sibuk dengan prioritas program mereka masing-masing, ada banyak surat yang perlu dijawab, dan mekanisme komunikasi antardepartemen sering tidak ada. Selain itu, staf organisasi mungkin tidak melihat manfaatnya untuk belajar dari rekanrekan sejawatnya.

Untuk meningkatkan pembelajaran dalam organisasi kita sendiri, kita perlu mengidentifikasi insentif organisasional yang tepat. Staf perlu diyakinkan bahwa dengan belajar mereka akan memperoleh sesuatu. Organisasi yang menggeluti persoalan hutan harus kreatif dalam mengembangkan struktur insentif dan penghargaan bagi stafnya yang berhasil mendorong pembelajaran, tidak hanya pembelajaran di luar organisasi tetapi juga di dalamnya, yakni dari rekan kerja dan staf lainnya.

\section{Penelitian dan Pengembangan}

Ada beberapa implikasi pengalaman kami dalam menerapkan ACM untuk penelitian dan pengembangan program kehutanan yang perlu mendapat perhatian.

Pertama, dibutuhkan upaya untuk menjembatani kesenjangan di antara kantor para pembuat kebijakan dan perancang proyek serta "kehidupan nyata". Sering kita melihat bahwa orang-orang sibuk, banyak kegiatan yang nampaknya menjadi lebih mendesak daripada kegiatan lapangan, ataupun sumber daya keuangan tidak ada. Guna mengatasi masalah ini, organisasi-organisasi pendidikan dan pelatihan dapat mengambil peran dalam mengembangkan materi pelatihan, buku-buku pedoman, atau alat-alat bantu untuk "mengumpulkan pengalaman lapangan" dengan lebih efektif. Pengalaman lapangan sangat diperlukan untuk mengarahkan para pembuat kebijakan dan perancang program; staf lapangan merupakan salah satu narasumber untuk hal ini.

Di atas telah kami sebutkan bahwa para fasilitator multipihak yang efektif sangat dibutuhkan. Suatu anggapan umum adalah bahwa staf lapangan, baik pada instansi-instansi pemerintah maupun LSM-LSM, telah memiliki kemampuan untuk menggunakan metode-metode partisipatif dalam memfasilitasi pemangkupemangku kepentingan. Namun pengalaman kami menunjukkan bahwa anggapan 
itu sering kurang benar; para fasilitator yang mempromosikan pembelajaran di kalangan para pemangku kepentingan membutuhkan keahlian dan kemampuan tertentu yang relatif baru bagi kebanyakan organisasi dan staf lapangan yang menggeluti bidang pengelolaan hutan, sementara kemampuan itu belum dimiliki atau dikuasai sepenuhnya. Karenanya, pelatihan untuk fasilitator dan pelatihan untuk para pelatih (ToT) dalam hal fasilitasi multipihak diperlukan untuk berbagai instansi dan organisasi yang bekerja di bidang kehutanan.

Berdasarkan penelitian kami sendiri, kami mengidentifikasi beberapa persoalan yang memerlukan pengkajian lebih lanjut. Kita perlu mengetahui lebih banyak tentang:

- Insentif ${ }^{22}$ dan disinsentif bagi pembelajaran dan kolaborasi antara berbagai pemangku kepentingan kehutanan

- Bagaimana pembelajaran antara para pemangku kepentingan mempengaruhi lingkungan alam mereka, dan sebaliknya

- Keahlian, pengetahuan, dan sikap apa yang dibutuhkan para fasilitator multipihak agar dapat bekerja dengan efektif

- Budaya kelembagaan apa yang diperlukan untuk mendukung pembelajaran dalam bidang kehutanan, dan sejauhmana birokrasi dapat direformasi agar mendukung pembelajaran

- Terakhir, bentuk kepemimpinan apa yang dibutuhkan pada berbagai tingkatan pengelolaan hutan untuk mendukung pembelajaran dalam lingkungan yang kompleks dan tidak pasti.

\section{Pendanaan Pembelajaran Bersama}

Kebutuhan pembelajaran bersama antara para pemangku kepentingan dalam program-program kehutanan juga berimplikasi pada pendanaan. Para donor sangat perlu menyadari bahwa pendanaan program pembelajaran bersama sangat berbeda dari pendanaan program lainnya. Keluaran-keluaran program pembelajaran bersama sering tidak dapat tercapai dalam waktu yang singkat. Ini berarti bahwa tujuan proyek perlu dirumuskan dalam bentuk keluaran-keluaran proses dan bahwa komitmen jangka panjang untuk program seperti itu sangat dibutuhkan.

Implikasi lainnya adalah bahwa para penyandang dana perlu mengembangkan perangkat-perangkat alternatif untuk pertanggungjawaban proyek, dan untuk ini kreativitas sangat diperlukan. Misalnya, di samping kerangka logis (logical framework) proyek, perlulah dikembangkan cara-cara lain untuk memantau kemajuan proyek. Selain itu, penganggaran suatu proyek harus dapat mengakomodasikan kebutuhan-kebutuhan yang muncul kemudian berdasarkan kegiatan pembelajaran. 
Para penyandang dana sebaiknya mendorong organisasi-organisasi yang mengajukan proposal pendanaan untuk mengalokasikan anggaran yang memadai dalam pos tersendiri untuk kegiatan-kegiatan pelatihan fasilitasi multipihak dan pembelajaran organisasional. Alokasi biaya untuk pengembangan staf dan kegiatan belajar bersama di dalam organisasi sering sangat kurang, baik dalam anggaran instansi-instansi pemerintah, perusahaan, maupun LSM. Selain itu, sering diasumsikan bahwa kebanyakan staf lapangan telah cukup terampil dalam menggunakan metode partisipatif dalam memfasilitasi multipihak.

Pembentukan sebuah platform dan jaringan multipihak untuk mendukung proses pembelajaran bersama tentang berbagai persoalan kehutanan merupakan aspek penting lainnya yang membutuhkan perhatian dalam pendanaan programprogram pembelajaran.

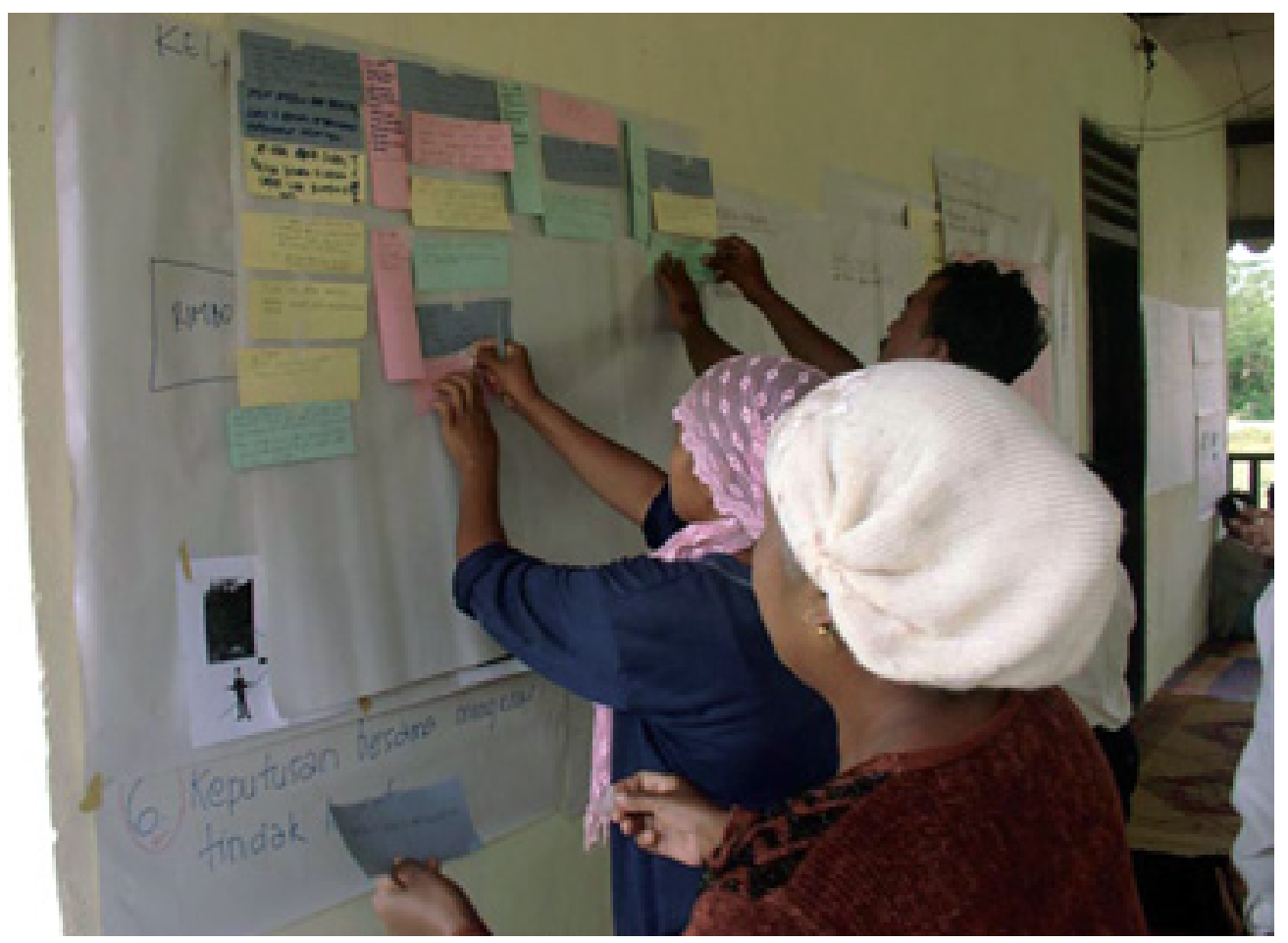

Dalam kegiatan belajar di tingkat lapangan, akan muncul kebutuhan-kebutuhan yang perlu diakomodir secara memadai dalam anggaran. 


\section{CATATAN PENUTUP}

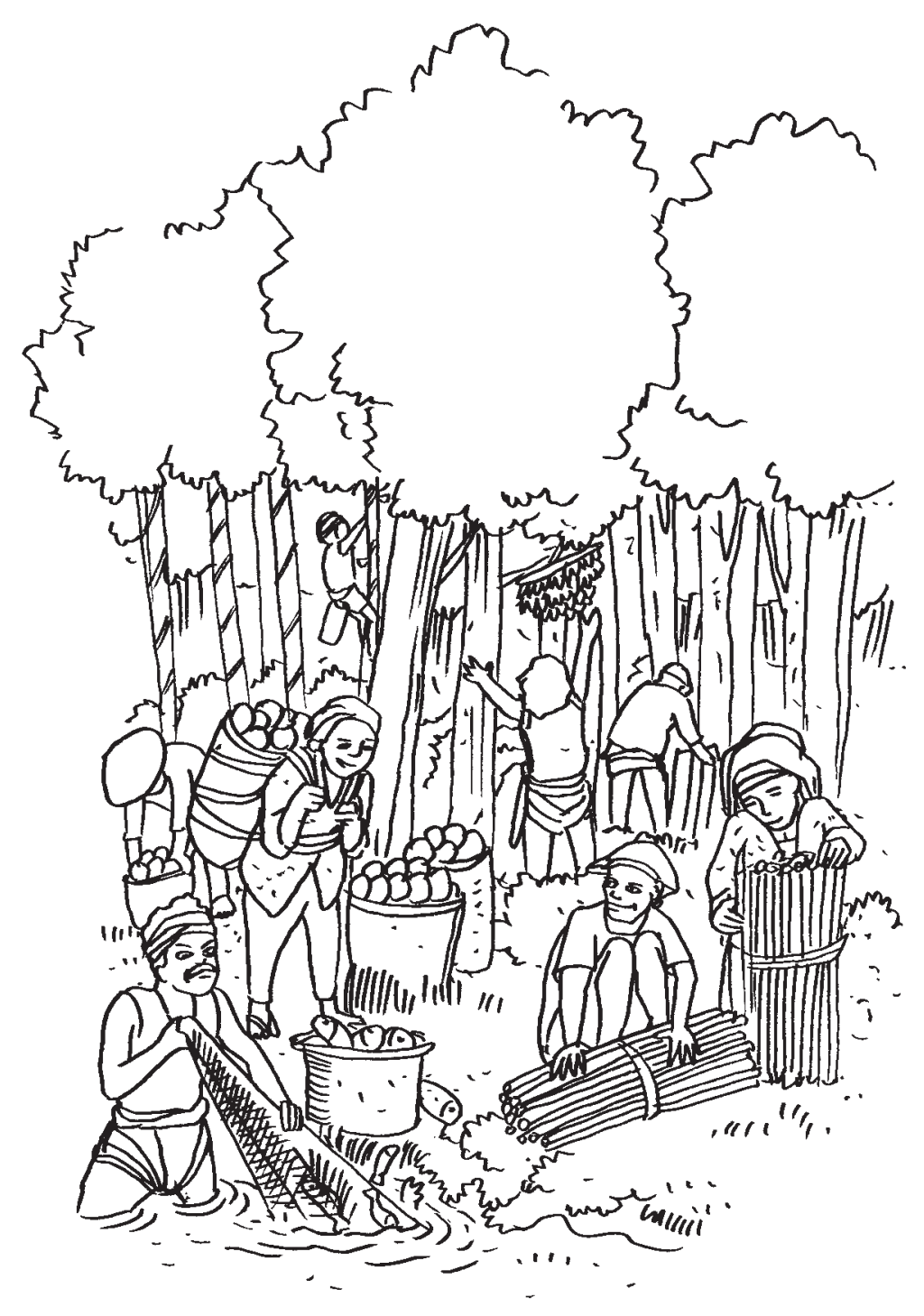


Sebagai manusia, pada dasarnya kita terjaga dan dapat memahami kenyataan. ... Kita menemukan bahwa, bagaimanapun, kita dapat menangani dunia kita, jagat raya kita, dengan semestinya dan seutuhnya secara luhur.

Chögyram Trungpa, guru agama Budha 
Sebagaimana dibuktikan kegiatan lapangan kami, pendekatan seperti ACM yang menekankan pada pembelajaran yang dilakukan dengan sadar dan cermat serta mengikuti siklus-siklus yang iteratif, memiliki dua keunggulan mendasar. Pertama, ACM memacu para pemangku kepentingan untuk belajar dari tindakan-tindakan mereka dan menyesuaikan strategi pengelolaan mereka berdasarkan proses pembelajaran tersebut. Kedua, ACM mendorong para pemangku kepentingan untuk membangun hubungan yang konstruktif di antara mereka.

Kami tidak mempunyai resep atau panduan yang baku untuk penerapan ACM atau pendekatan-pendekatan serupa. Apa yang telah kami coba sampaikan dalam buku ini hanyalah cara kami melakukannya agar para pembaca buku ini dapat menarik pelajaran dari pengalaman kami. Harapannya adalah tentu, para pembaca dapat mengembangkan kerangka panduan mereka sendiri, yang akan berkembang seiring dengan kemajuan program atau kegiatan di lapangan.

Kunci dari pendekatan seperti ini adalah menciptakan kondisi-kondisi yang tepat untuk memungkinkan para pemangku kepentingan belajar bersama. Dalam pengalaman kami kondisi-kondisi itu dapat diciptakan jika kegiatan fasilitasi dilakukan atas dasar empat prinsip:

- Para pemangku kepentingan harus mempunyai rasa kepemilikan atas pembelajarannya sendiri

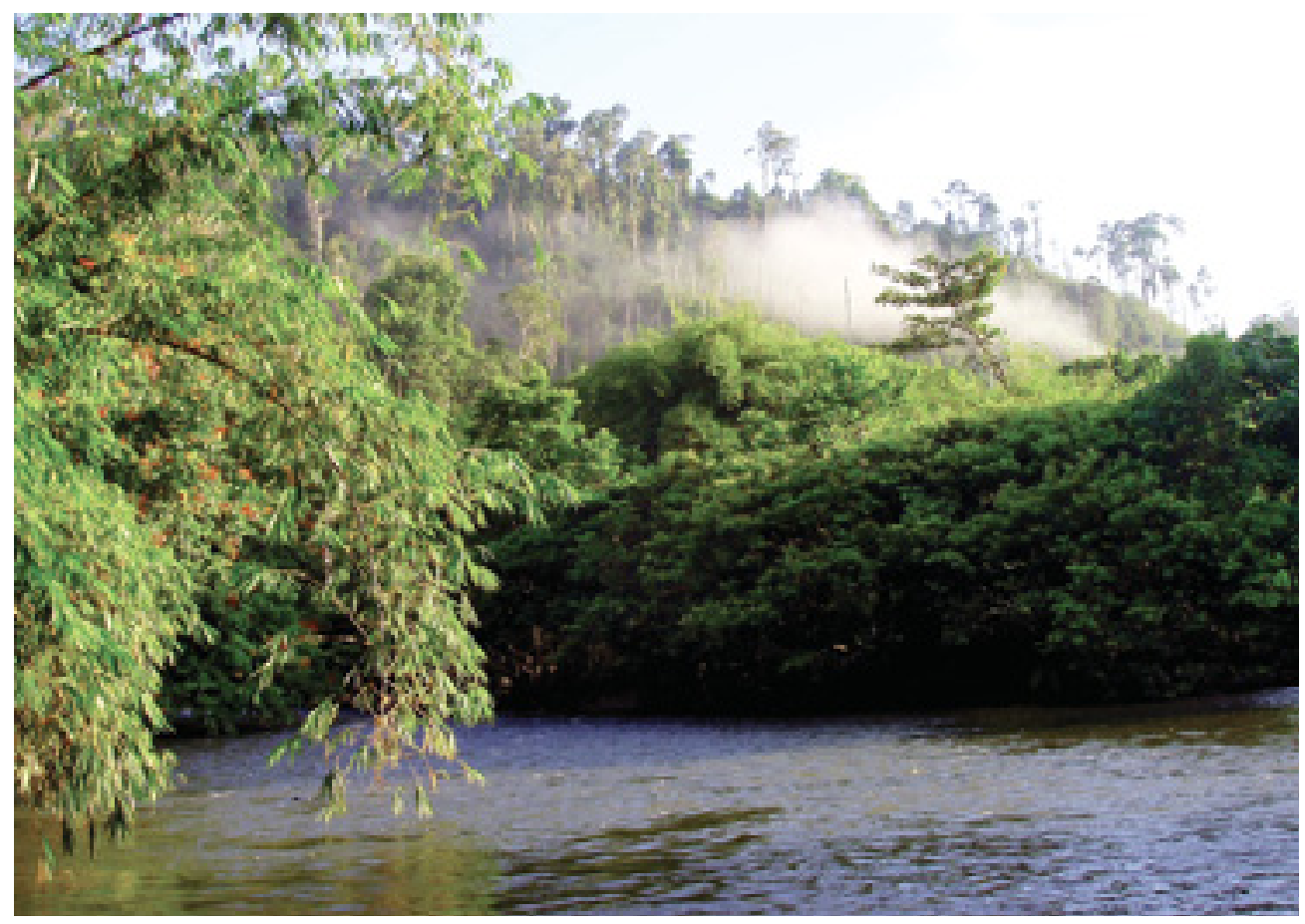

Menciptakan kondisi yang tepat untuk pembelajaran para pemangku kepentingan akan berdampak positif terhadap keadaan hutan dan hubungan antara para pemangku kepentingan lokal. 
- Semua pemangku kepentingan harus terwakili dalam kegiatan-kegiatan belajar

- Pengalaman harus menjadi inti pembelajaran

- Pembelajaran harus terjadi melalui komunikasi.

Kondisi-kondisi itu tidak akan muncul dengan sendirinya. Peran fasilitator sangat menentukan. Agar efektif, seorang fasilitator pembelajaran harus menjadi pendengar yang baik, memiliki rasa keadilan, dan mampu mendorong proses komunikasi antara para pemangku kepentingan. Terakhir, yang tidak kalah pentingnya, ia harus memiliki kemauan untuk belajar dari tindakan-tindakannya dalam memfasilitasi para pemangku kepentingan, dan senantiasa menyesuaikan strategi fasilitasinya sesuai dengan pembelajaran itu.

Seperti telah dibuktikan kegiatan lapangan kami, pendekatan seperti ACM yang menekankan pada pembelajaran dan proses, dapat meningkatkan kapasitas manusia (modal manusia) dan mendorong terbangunnya hubungan antara pemangku kepentingan yang konstruktif (modal sosial). Karena keterbatasan waktu penelitian, kami tidak dapat mengamati apakah ACM juga menghasilkan perubahan-perubahan modal sumber daya alam, modal fisik, ataupun modal finansial. Walaupun demikian, kami menemukan beberapa bukti bahwa dalam jangka panjang peningkatan modal sosial dapat membantu terbentuknya ketiga modal itu.

Pengalaman kami merupakan suatu pencarian yang kaya, meskipun bukan sesuatu yang selalu mudah, guna menemukan bentuk-bentuk pengelolaan hutan yang baru dan kolaboratif. Dari pengalaman ini, sebagai peneliti-peneliti aksi yang belajar bersama pihak-pihak lokal, kami telah memperoleh banyak pelajaran yang sangat berharga. Karena pengalaman inilah kami mengetahui dengan pasti bahwa pembelajaran dan proses sangat bermakna dalam pemanfaatan dan pengelolaan hutan oleh para pemangku kepentingan.

Nah, sekarang kami telah berbagi pengalaman. Kami tertarik untuk mendengar pengalaman Anda juga! 
LAMPIRAN

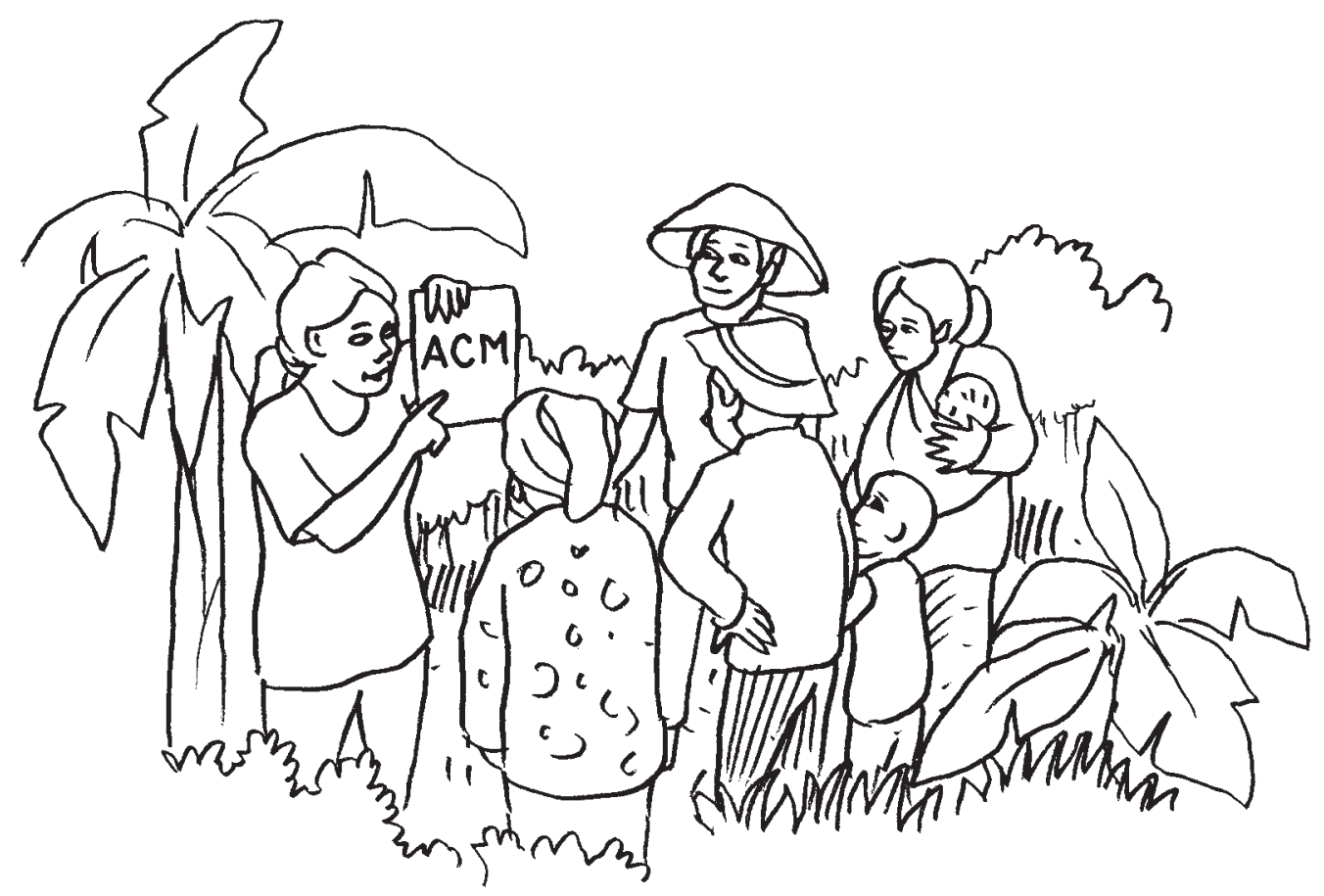





\section{LAMPIRAN 1}

\section{SUATU KERANGKA UNTUK MENERAPKAN ACM}

Lampiran ini menyajikan suatu kerangka untuk menerapkan ACM yang didasarkan pada pengalaman tim kami. Kerangka ini sebaiknya dilihat sebagai petunjuk indikatif dalam mendampingi para pemangku kepentingan untuk bersama-sama menghadapi permasalahan sumber daya lokal, bukannya sebagai pedoman teknis yang siap pakai. Anda tentu memiliki kebebasan penuh untuk menyesuaikan kerangka ini dengan kebutuhan pribadi Anda dan di tempat Anda bergiat. Idealnya, Anda membuat kerangka Anda sendiri, yang kemudian akan berkembang seiring dengan kemajuan kegiatan Anda dalam memfasilitasi para pemangku kepentingan. Kuncinya adalah bahwa sepanjang proses fasilitasi, Anda dengan sadar berusaha menciptakan kondisi yang tepat bagi para pemangku kepentingan untuk belajar bersama, bereksperimen dengan cara dan alat fasilitasi baru, merefleksikan dengan kritis peran Anda sebagai fasilitator pembelajaran, dan bersikap terbuka untuk melakukan penyesuaian (atau bahkan membuang!) cara fasilitasi lama yang kurang efektif.

Kerangka yang dipaparkan di sini memberikan langkah-langkah kunci penerapan ACM sebagaimana kami melakukannya. Kerangka ini dapat digunakan pada kegiatan dan program baru atau pada program yang sudah berlangsung selama beberapa waktu. Dengan kata lain, tidak ada aturan tentang kapan kita dapat memulai fasilitasi pembelajaran antara para pemangku kepentingan. Dari pengalaman, kami belajar bahwa ACM bisa memberi nilai tambah pada setiap situasi ketika para pemangku kepentingan berinteraksi, terlepas dari tahap program yang sedang dilaksanakan.

Ada tiga jenis kegiatan untuk membentuk keadaan yang tepat bagi pembelajaran para pemangku kepentingan:

1. Mempersiapkan pembelajaran

2. Mengorganisasikan pembelajaran

3. Memfasilitasi pembelajaran.

Dalam kerangka yang disajikan di bawah ini, tujuan setiap kegiatan disampaikan, langkah-langkah kunci dan bagaimana menerapkannya diuraikan, serta beberapa alat bantu atau metode dianjurkan untuk setiap langkah pelaksanaan. Pada Lampiran 2 Anda akan menemukan perangkat alat bantu yang memberi uraian singkat tentang alat-alat bantu atau metode-metode tersebut. 


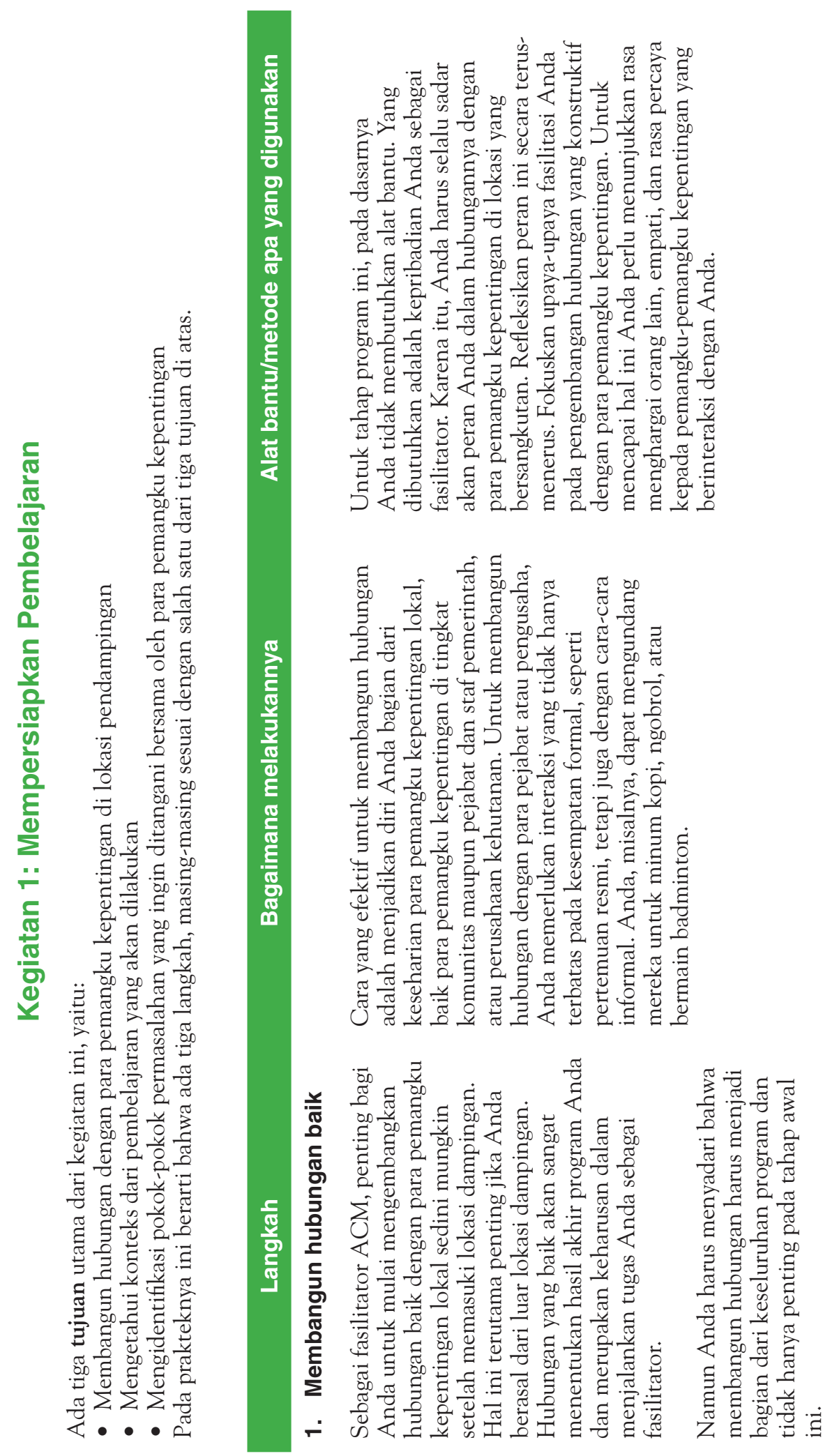




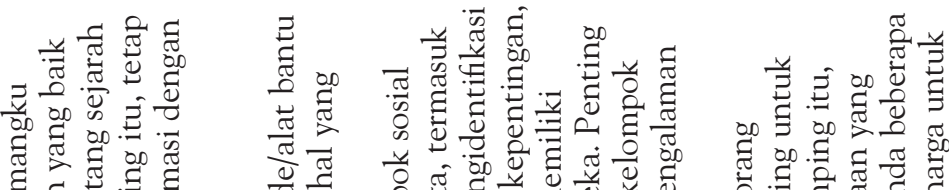

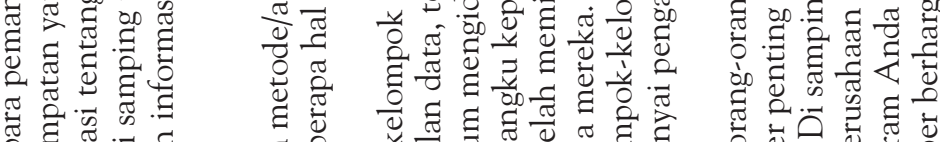

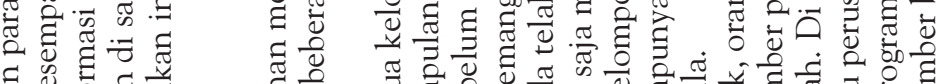

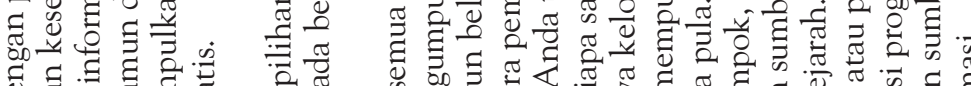

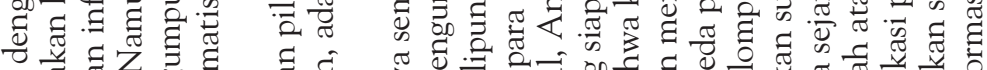

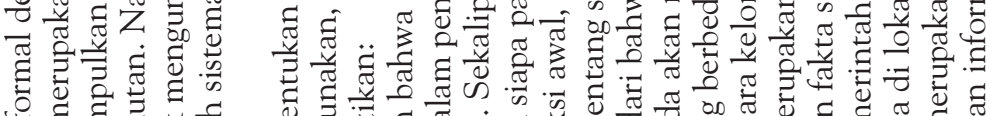

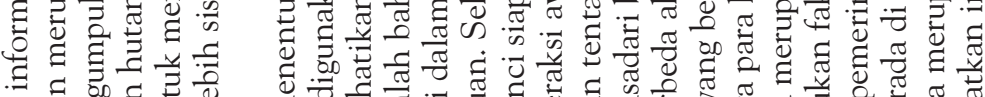

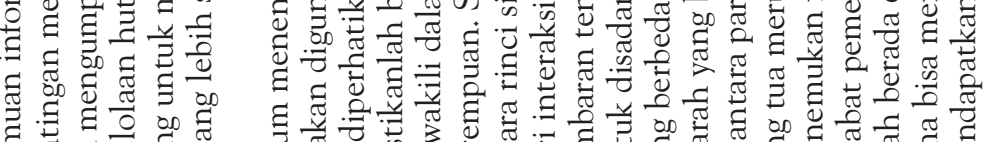

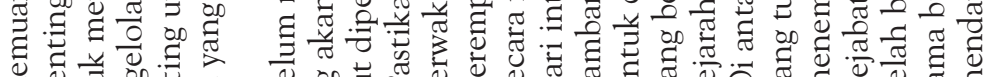

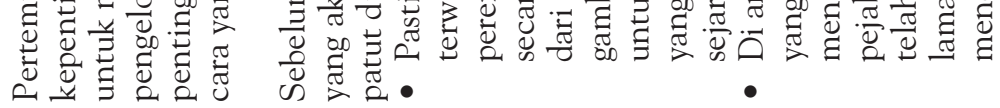

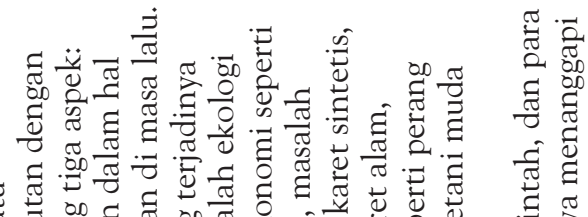

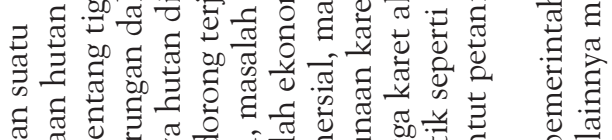

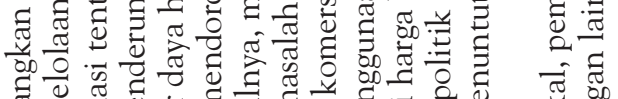

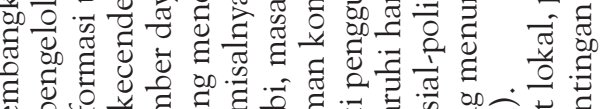

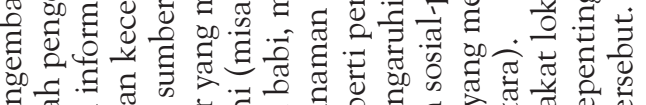

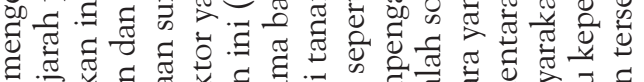

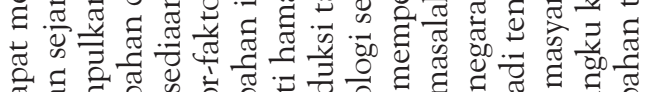

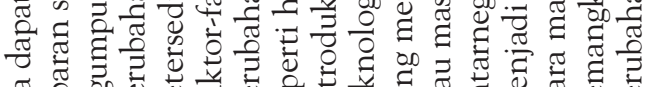

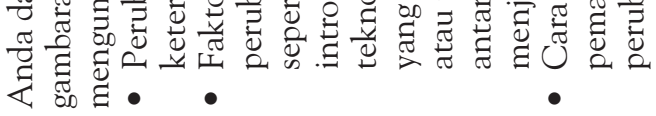
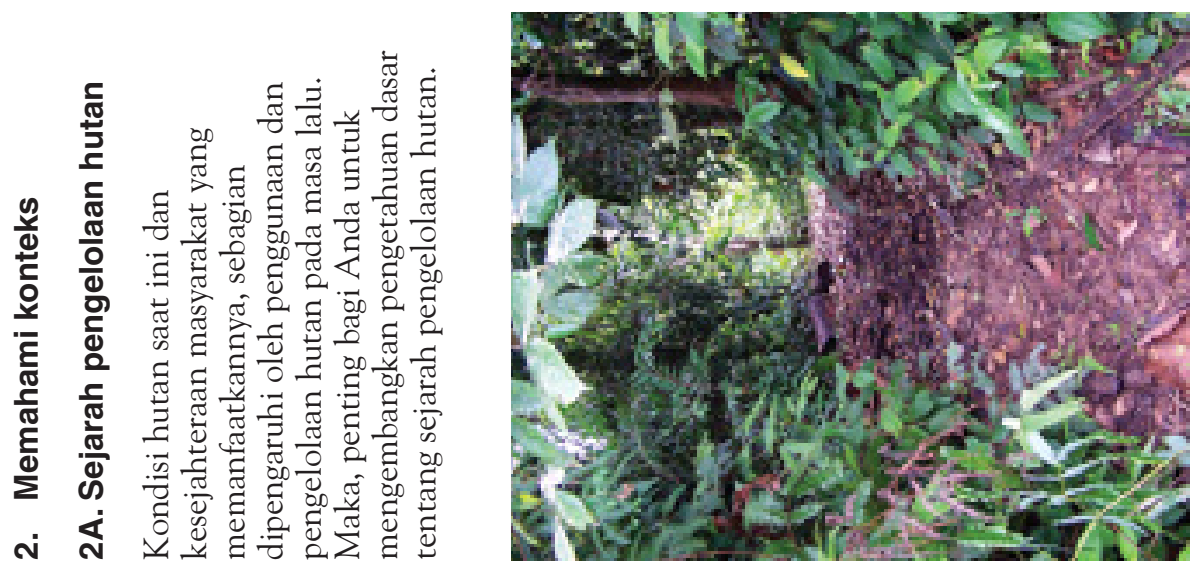

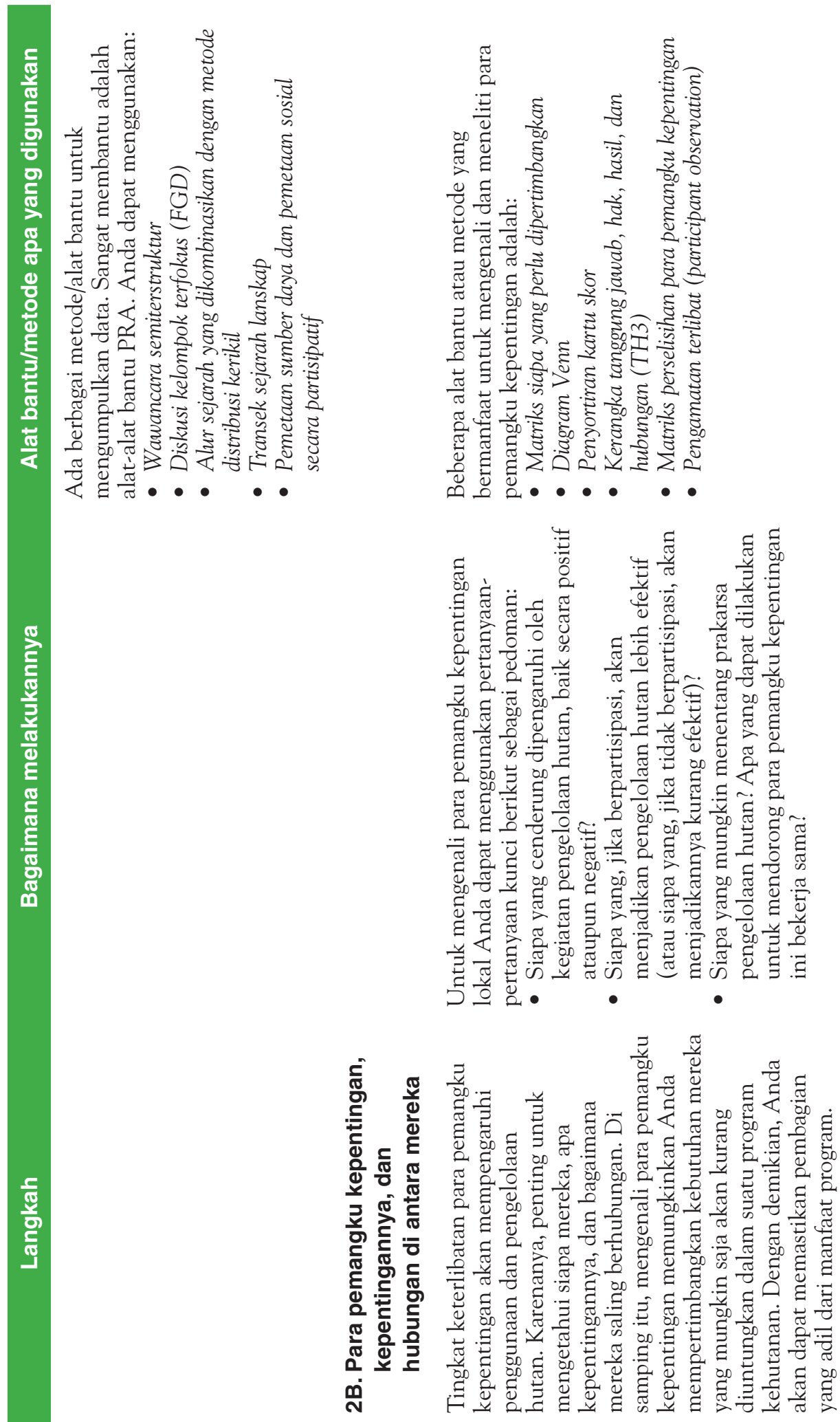


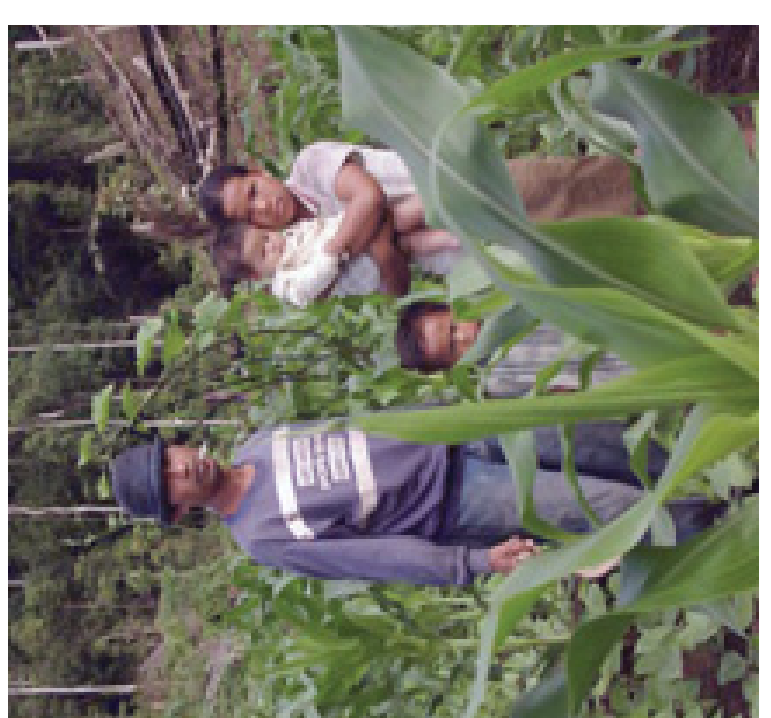

$\stackrel{0}{\Xi}$

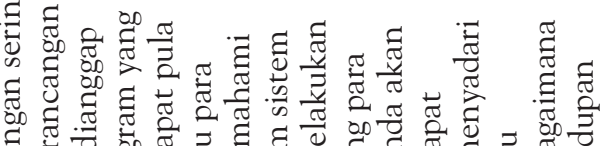

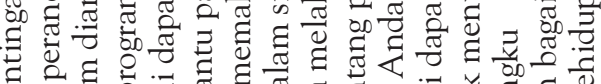

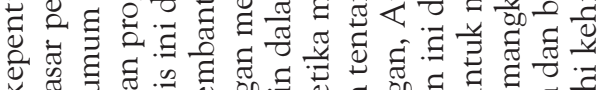

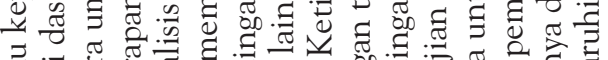

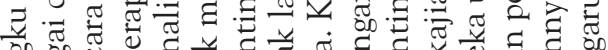
क्ष

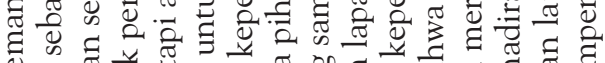

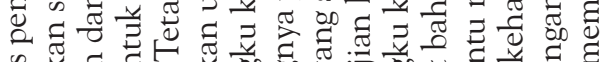

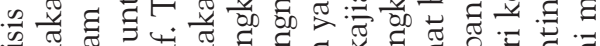

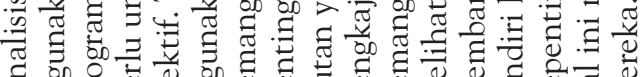

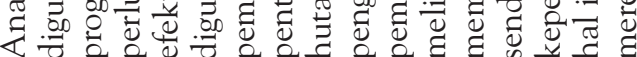

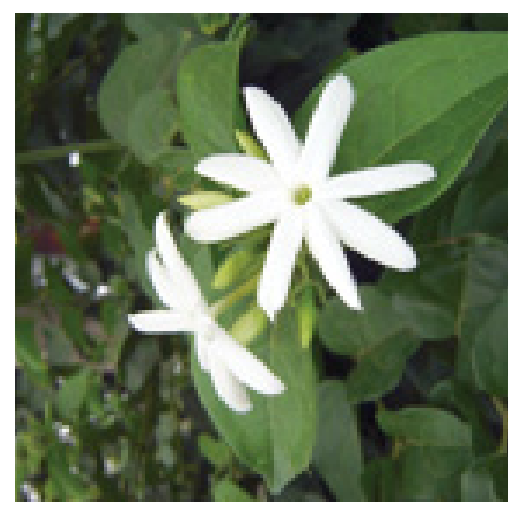




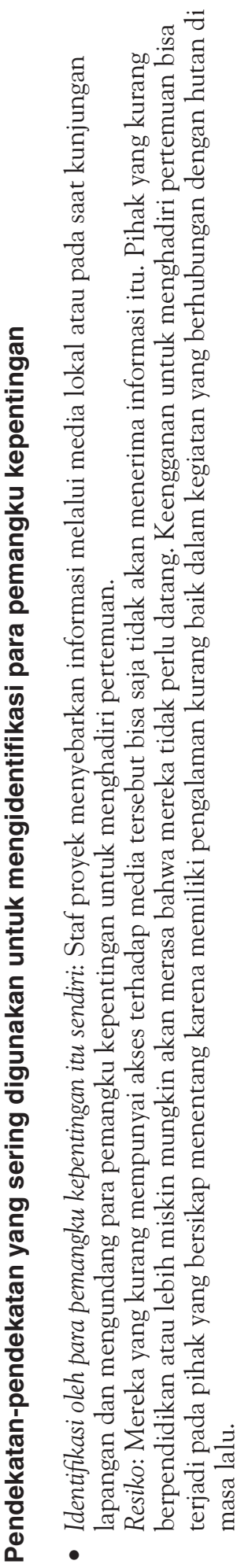


究

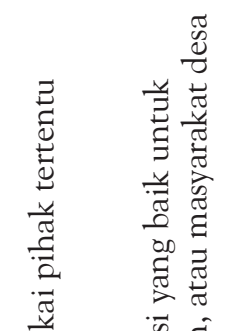

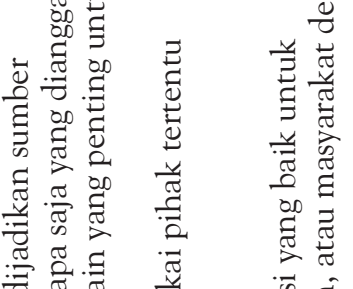

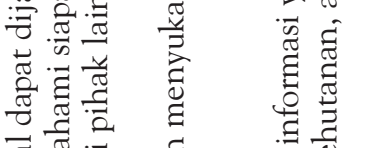

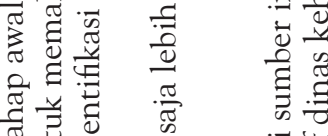

$\varpi \Xi$

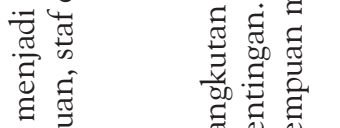

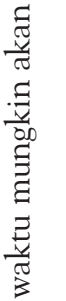

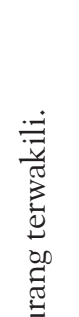

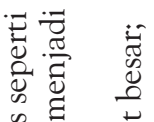

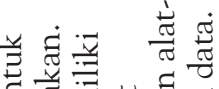

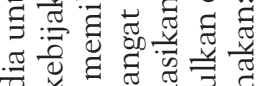

西

50 离

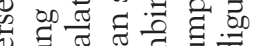

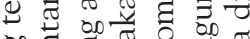

约

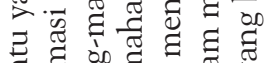

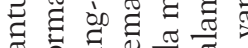

此

菏.

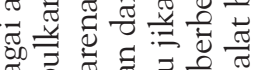

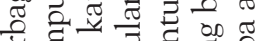

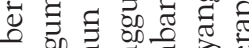

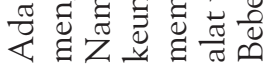

离

这范

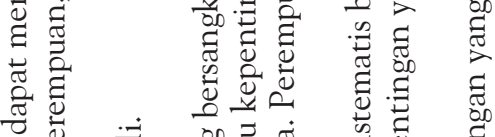

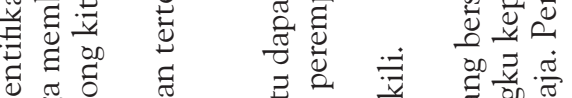

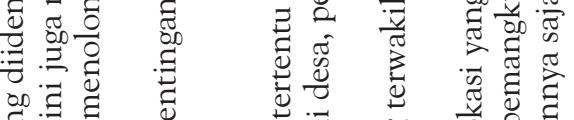

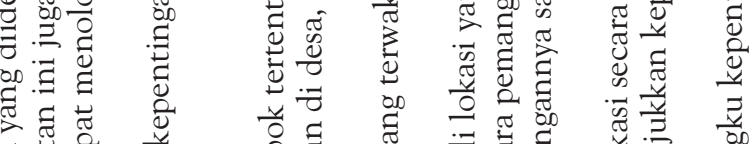

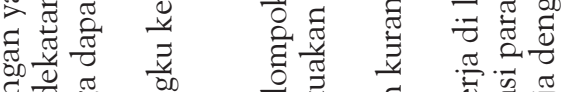

造 㐘

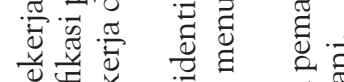

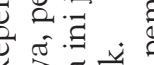

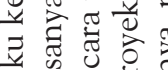

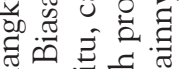

政

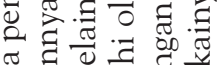

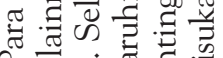

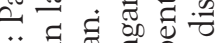

हैं

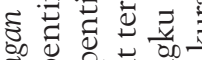

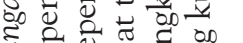

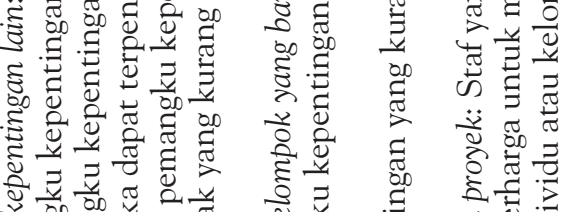

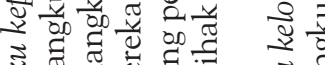

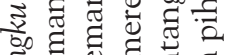

छे एँ.

플

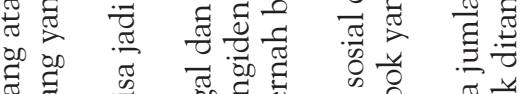

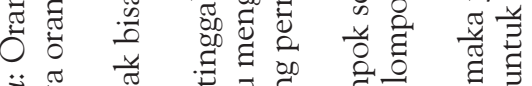

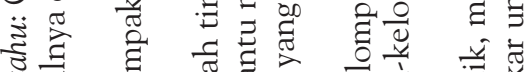

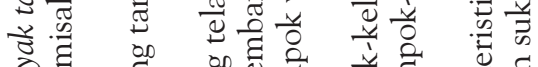

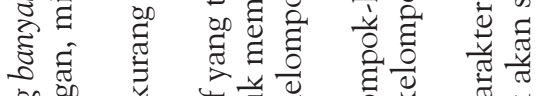

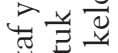

产芒

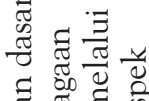

๘ี

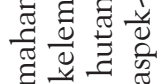

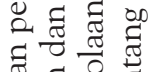

袈

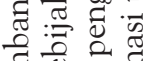

苟

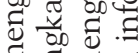

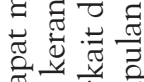

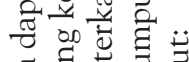

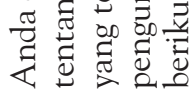

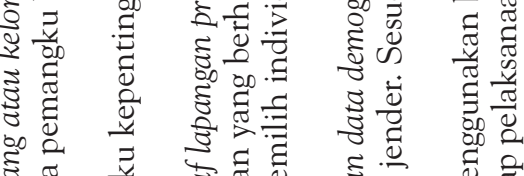

.

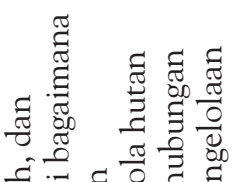

उ.

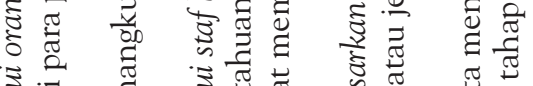

छ

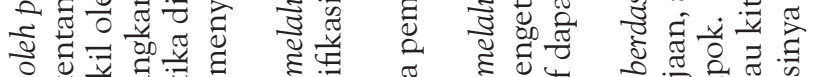

중

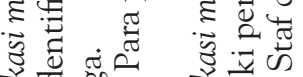

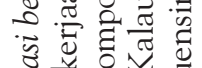

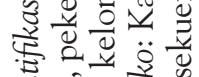

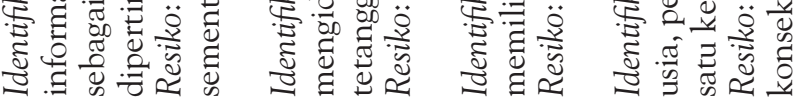

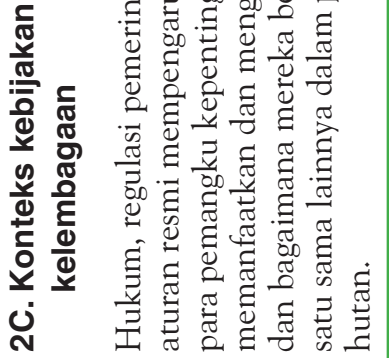



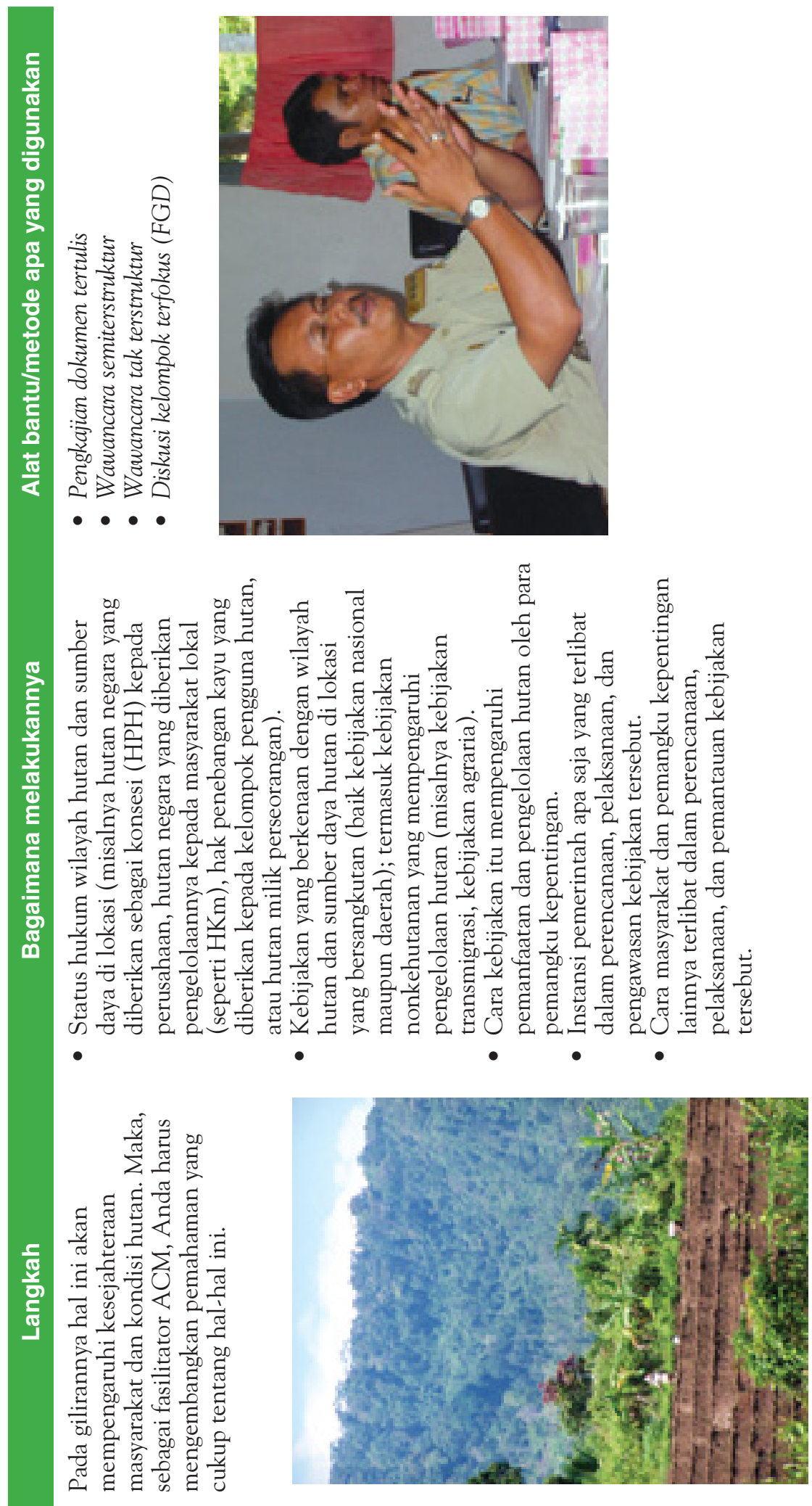


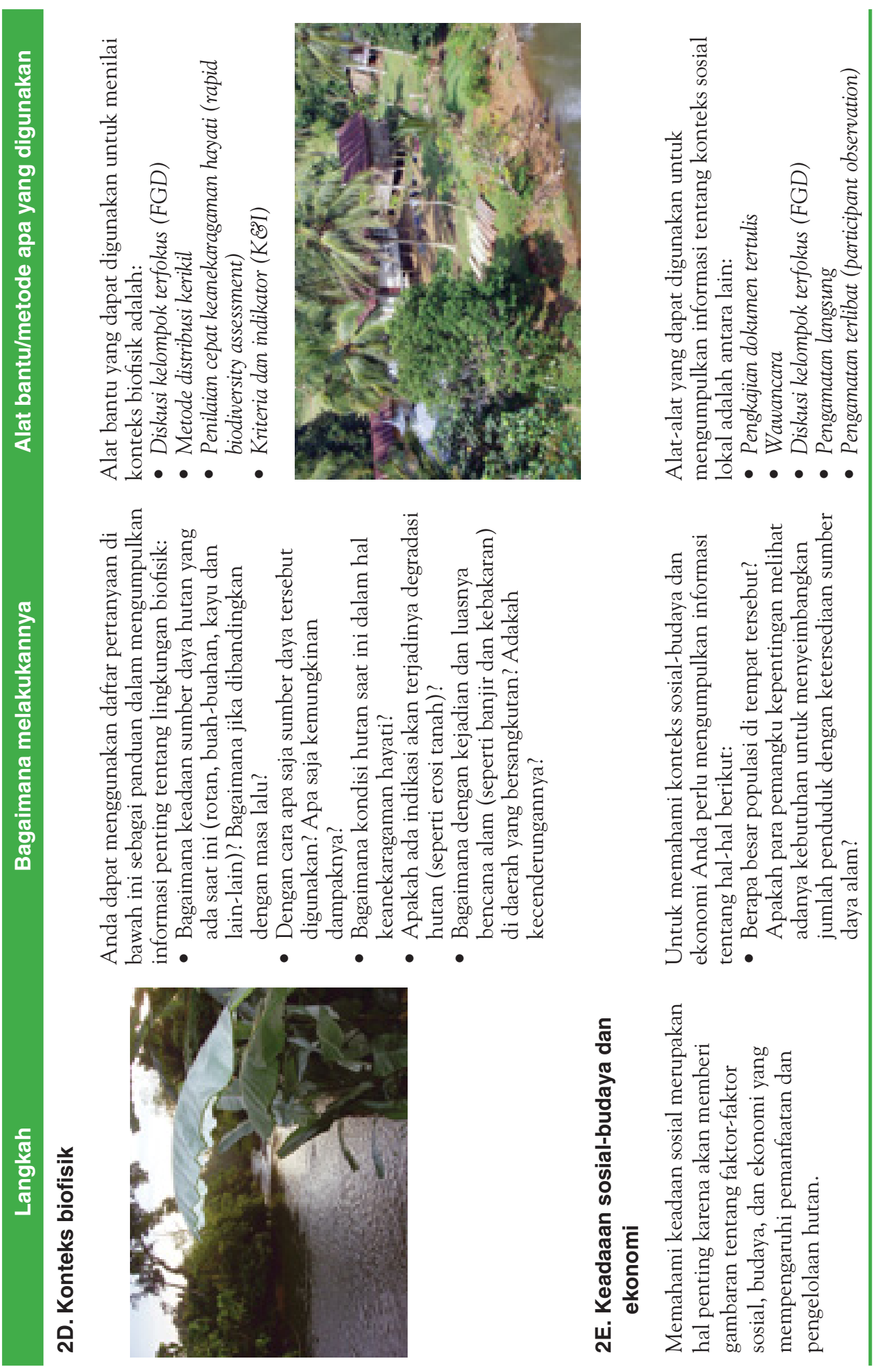




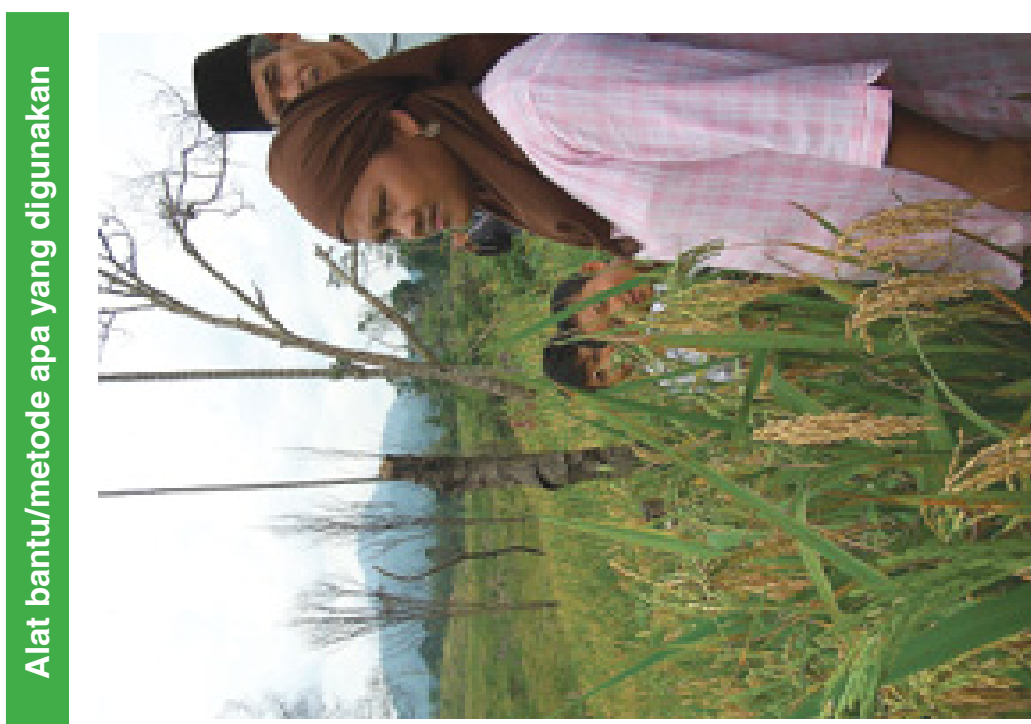

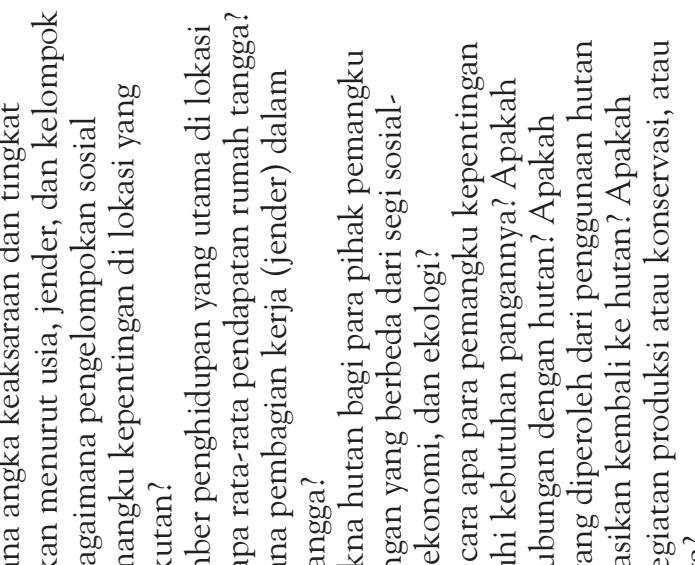

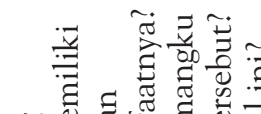
o

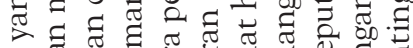

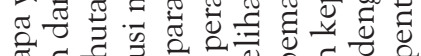
बै

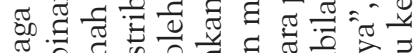

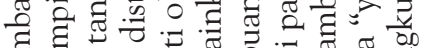

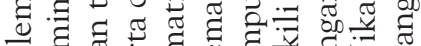

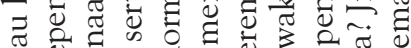
๘ั

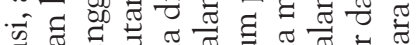
:

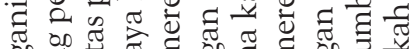
践

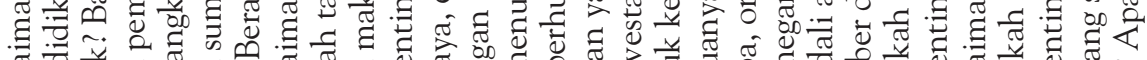
ज्ञ

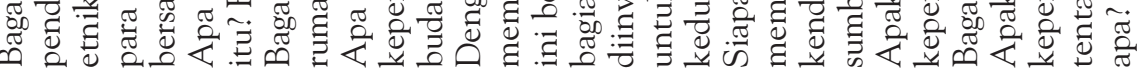

$\frac{\frac{2}{10}}{\frac{10}{20}}$

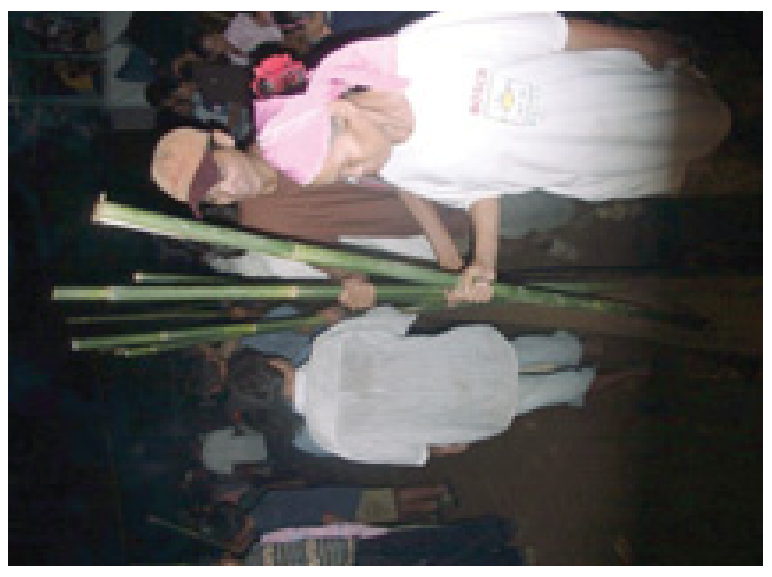



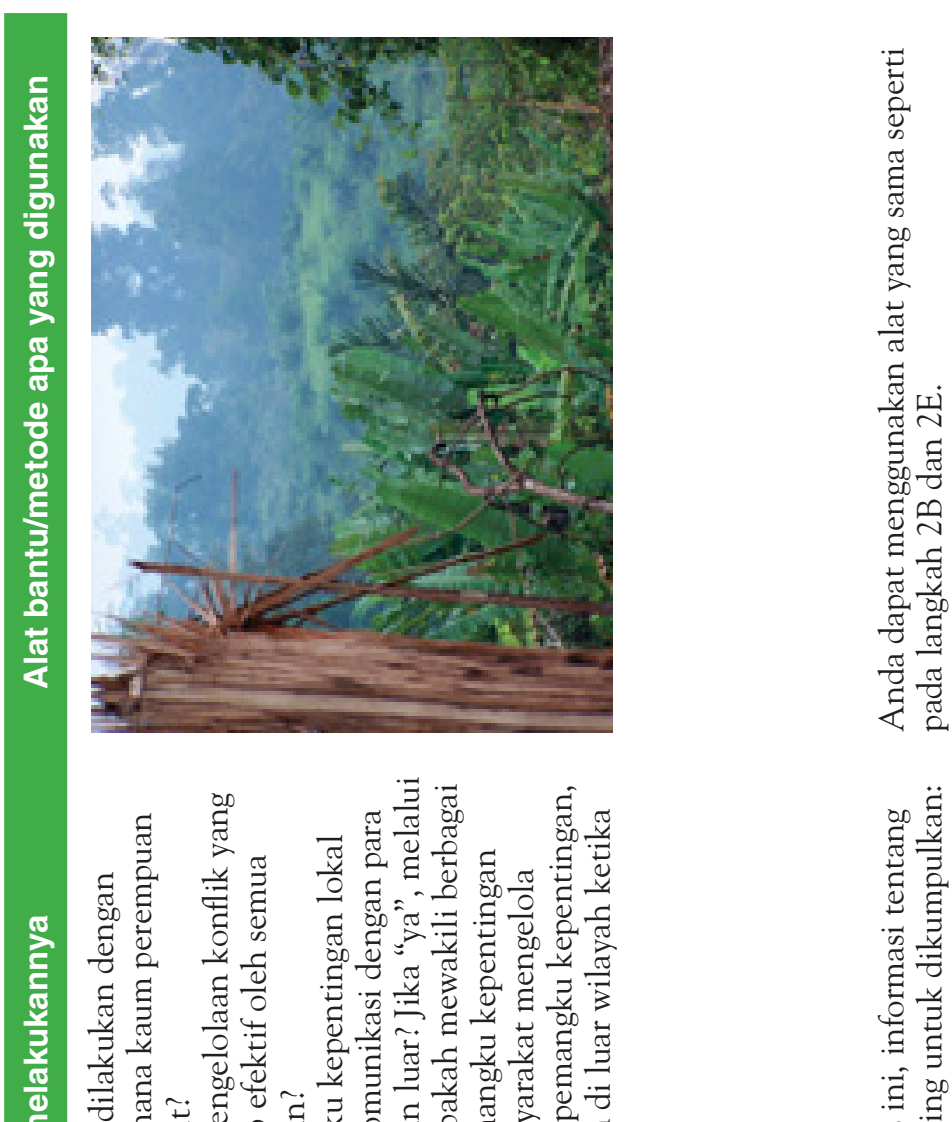

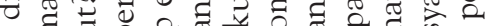

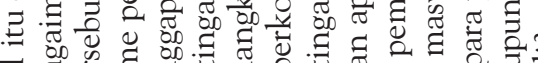

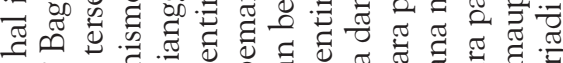
๙

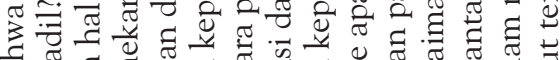

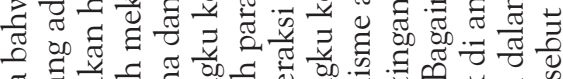

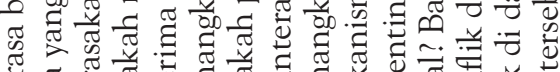

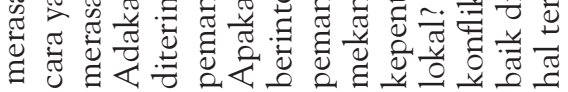
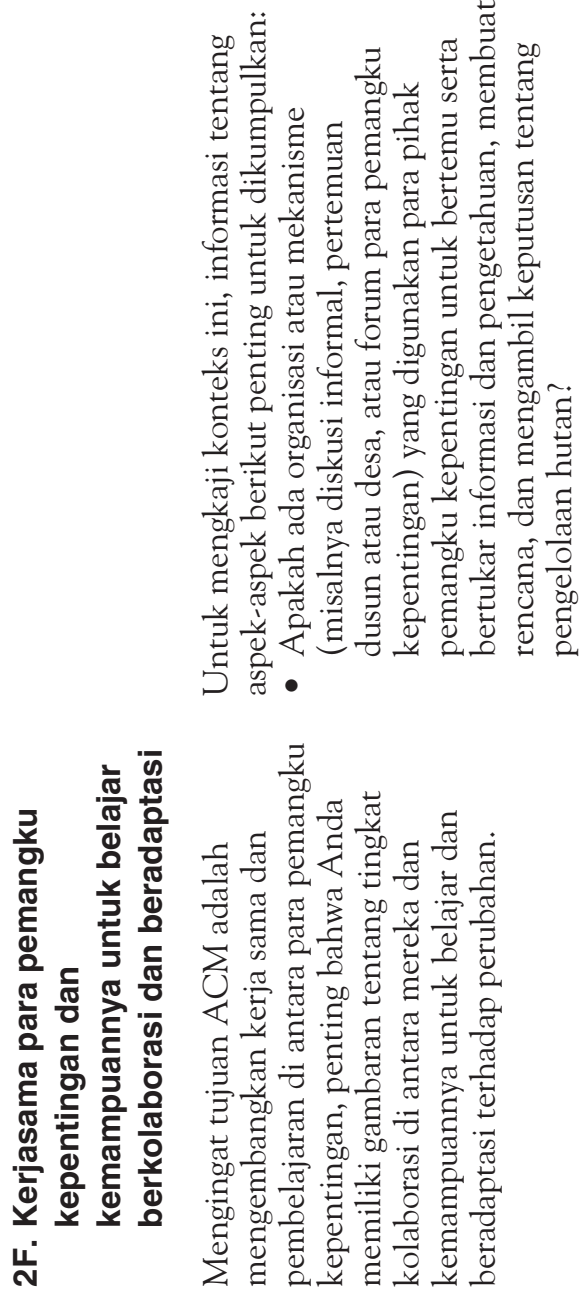


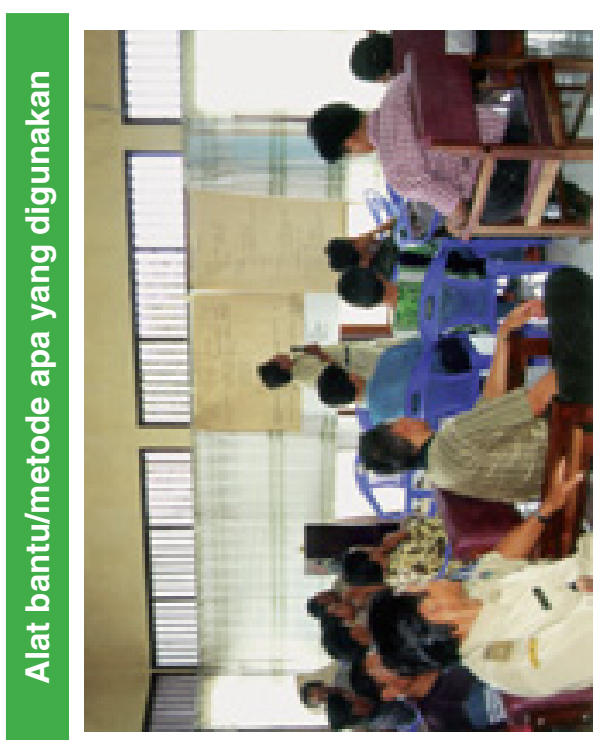

ำ

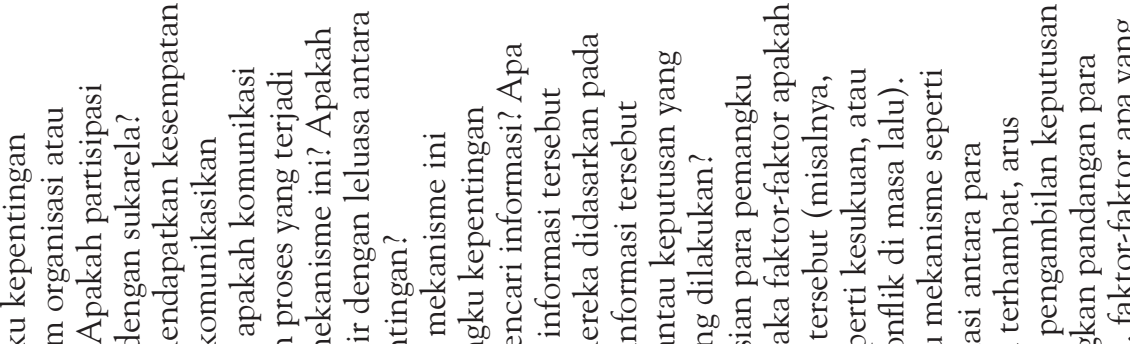

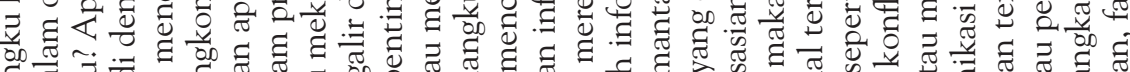

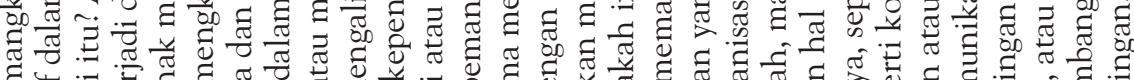

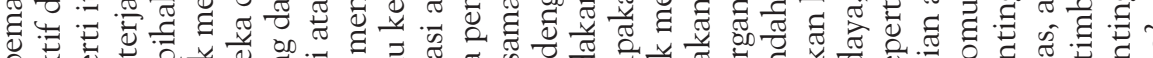

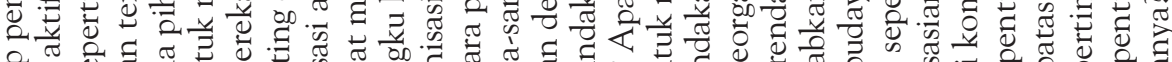

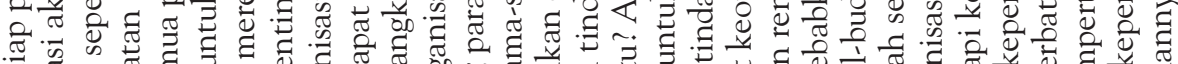

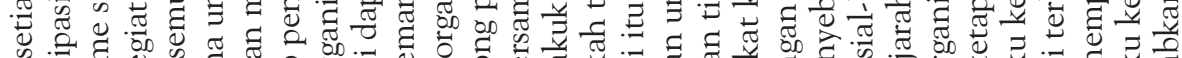

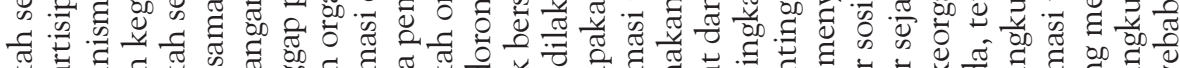

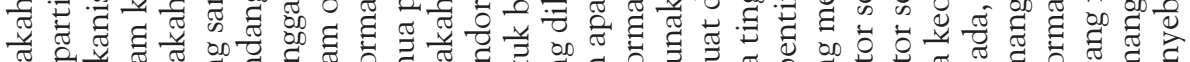

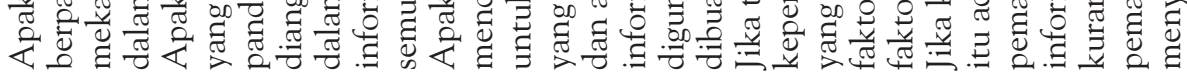

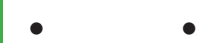

$\frac{\frac{5}{9}}{\frac{9}{9}}$

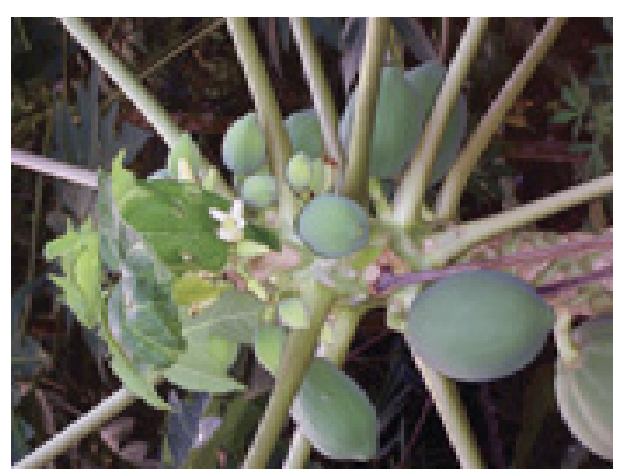




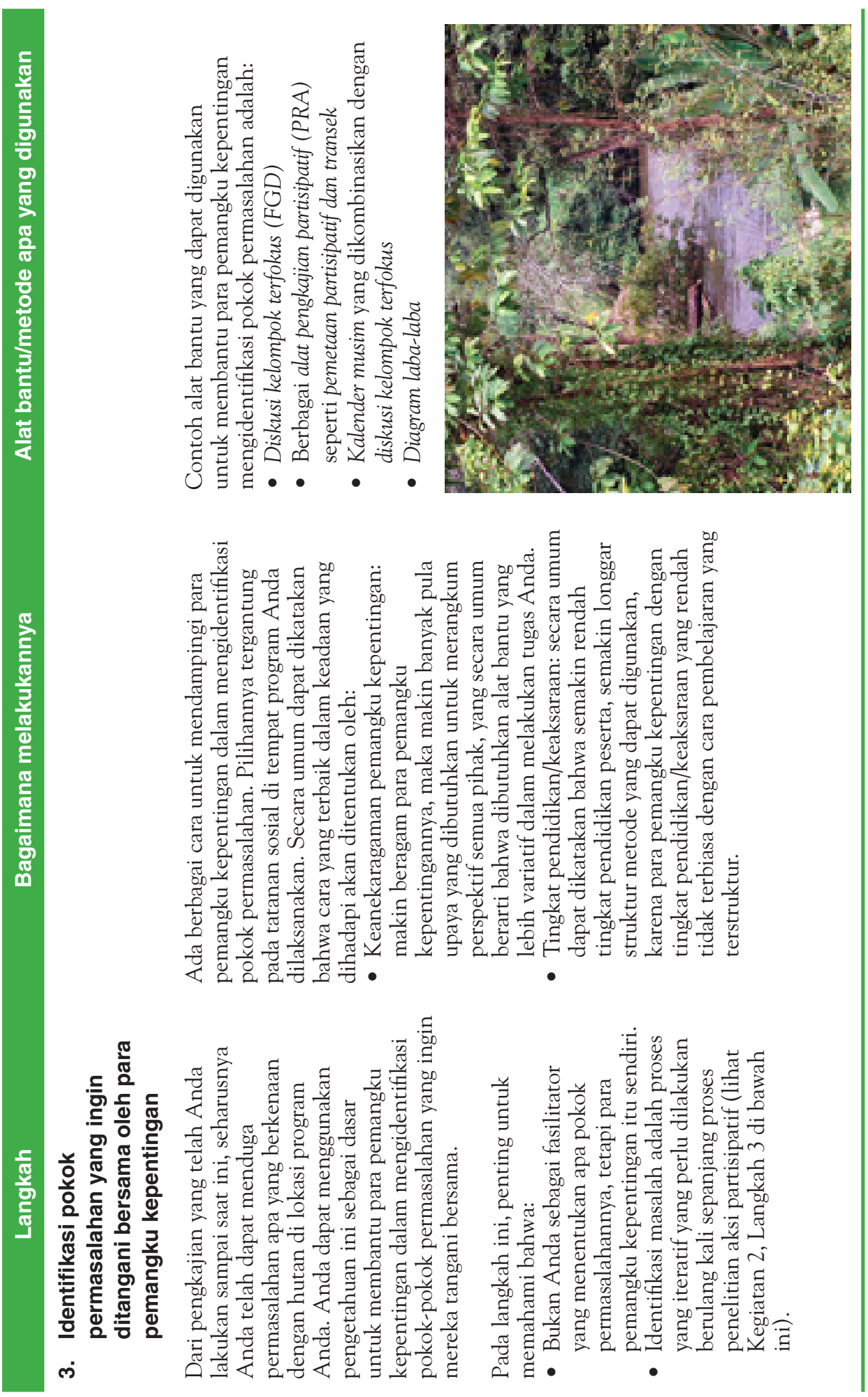




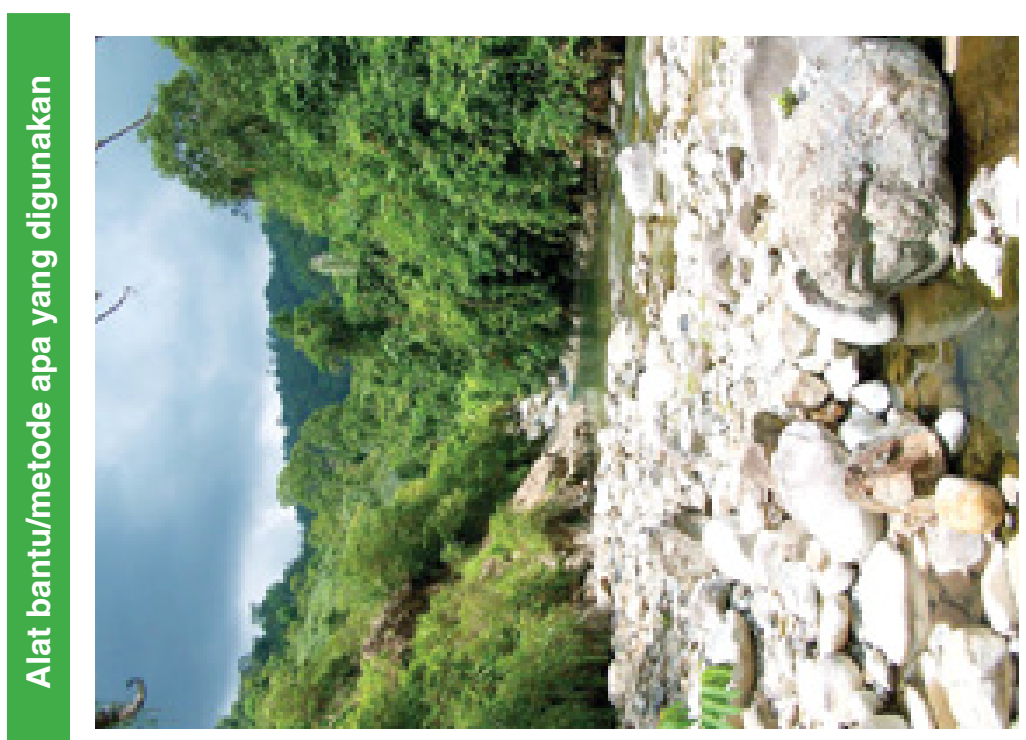

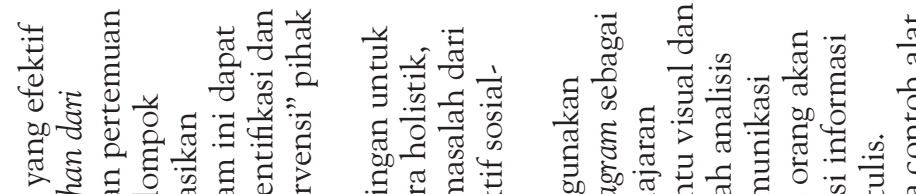

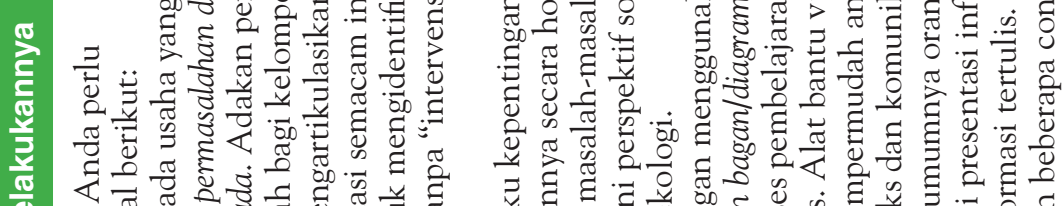

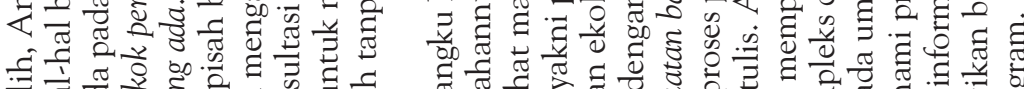

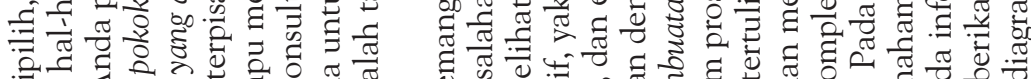

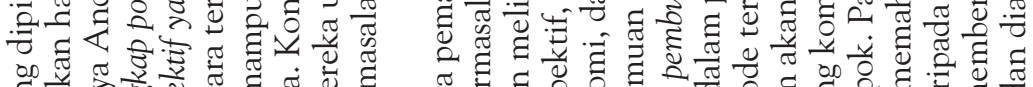

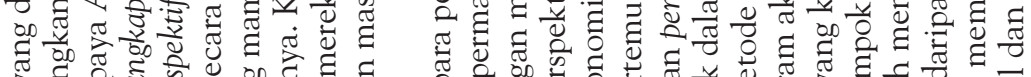

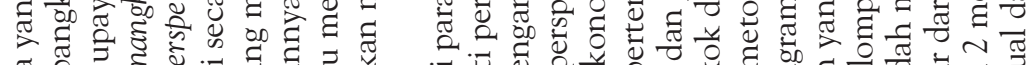

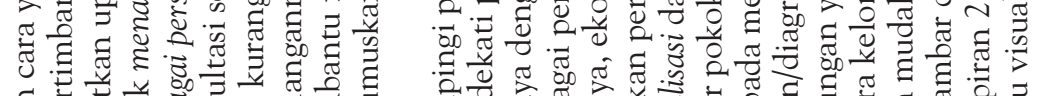

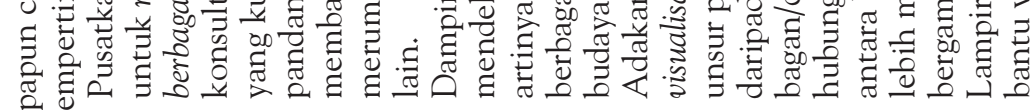

들

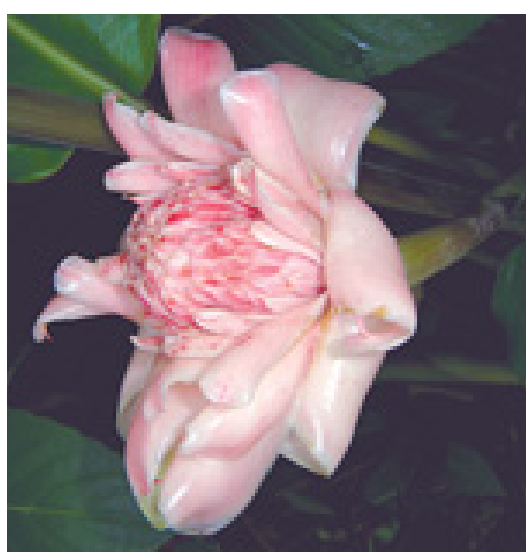




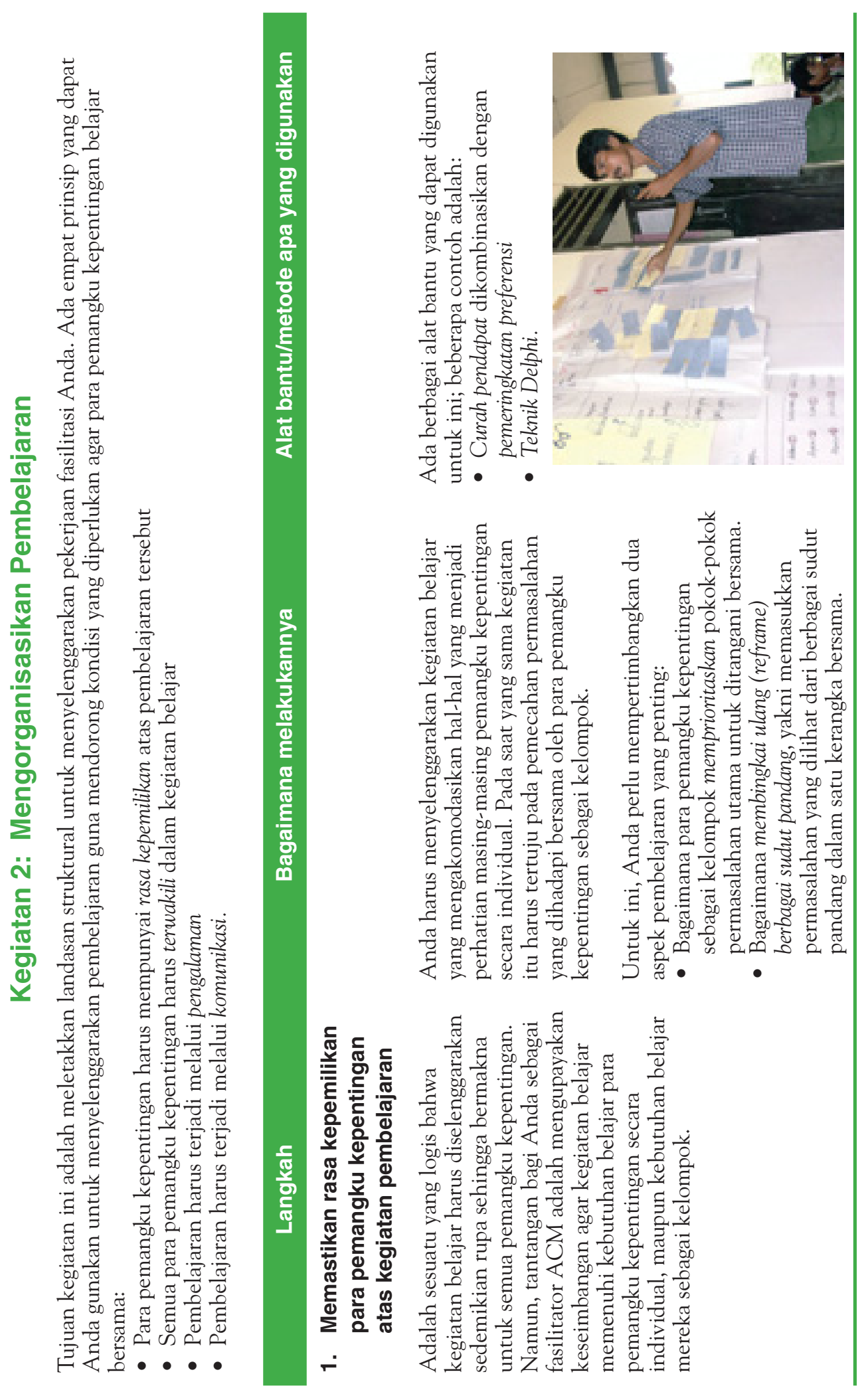



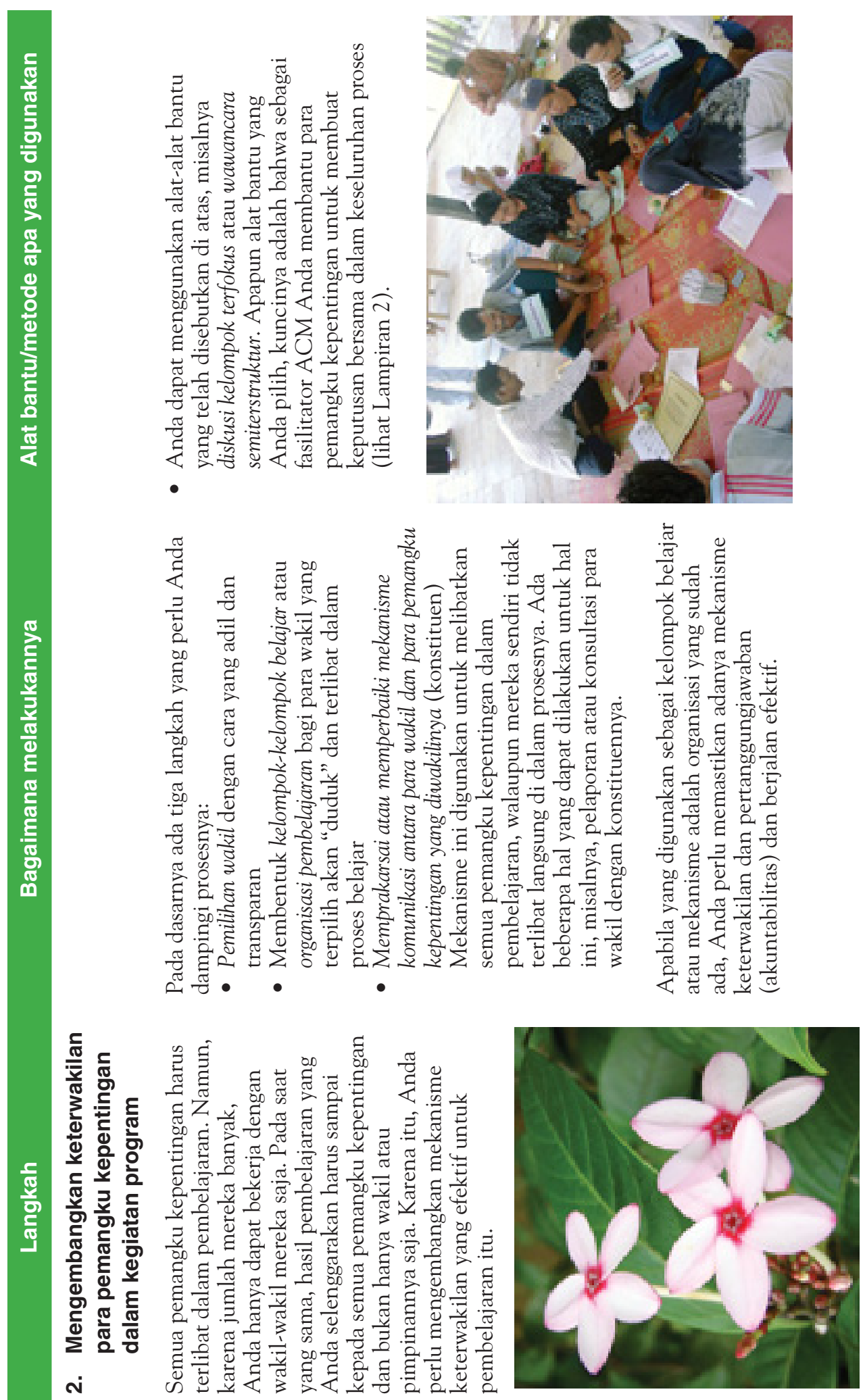


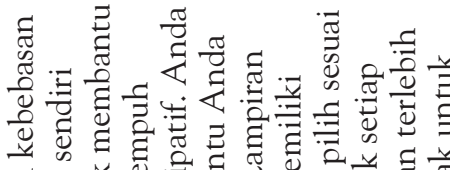

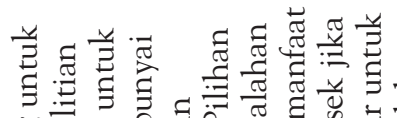
on 党

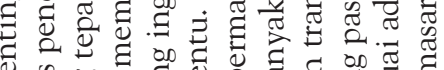

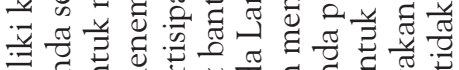

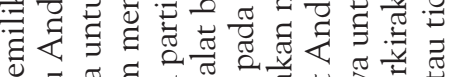

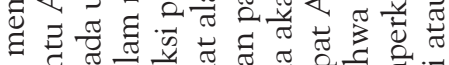

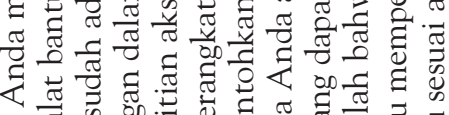

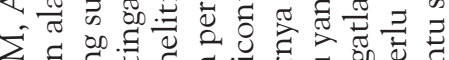

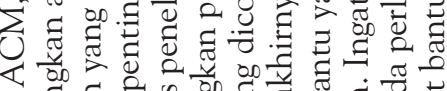

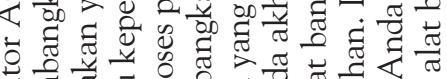

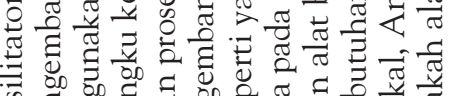

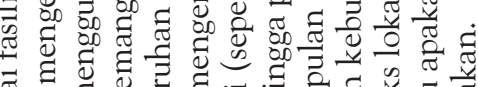
要

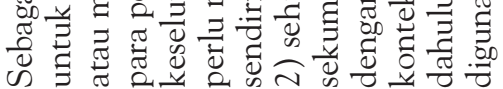

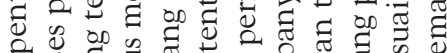
క.

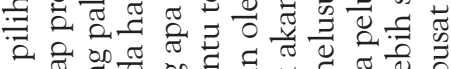
ब. बै

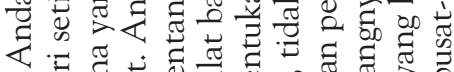

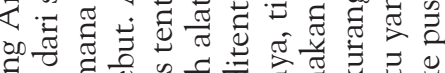
记 을

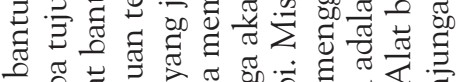

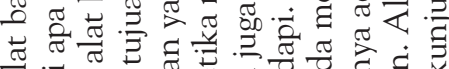

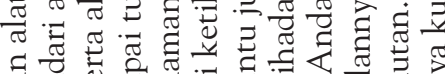

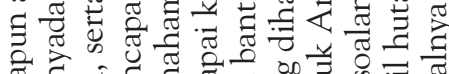

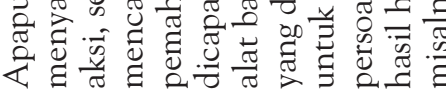

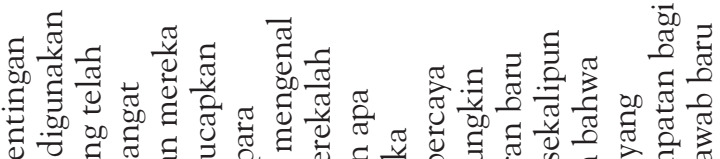

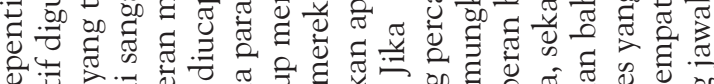

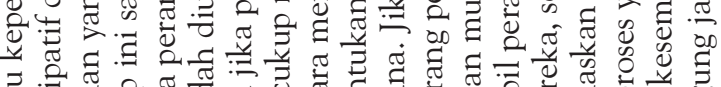

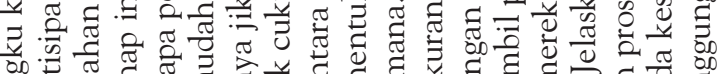

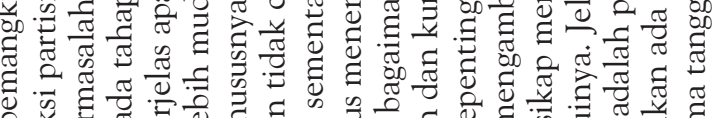

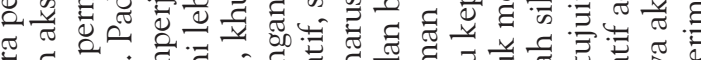

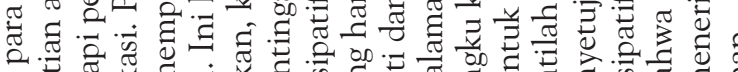

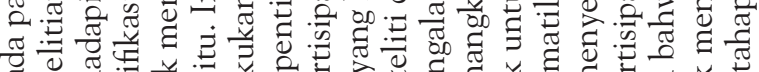
记

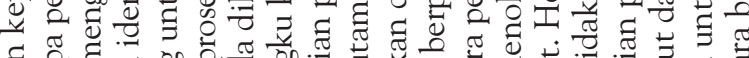
打

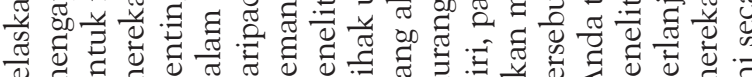

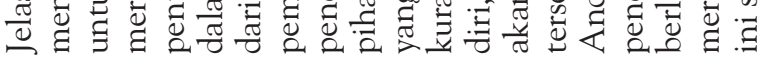

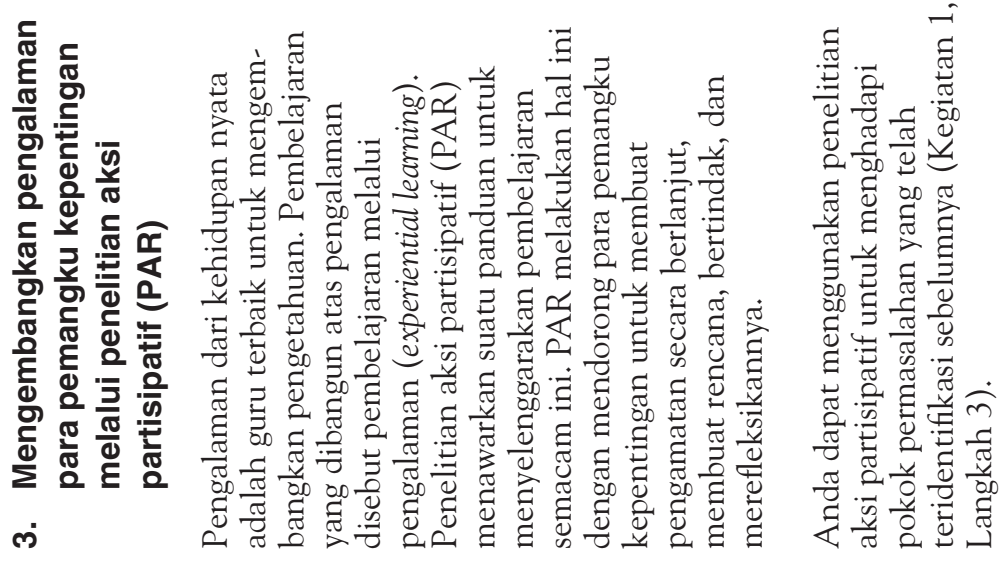



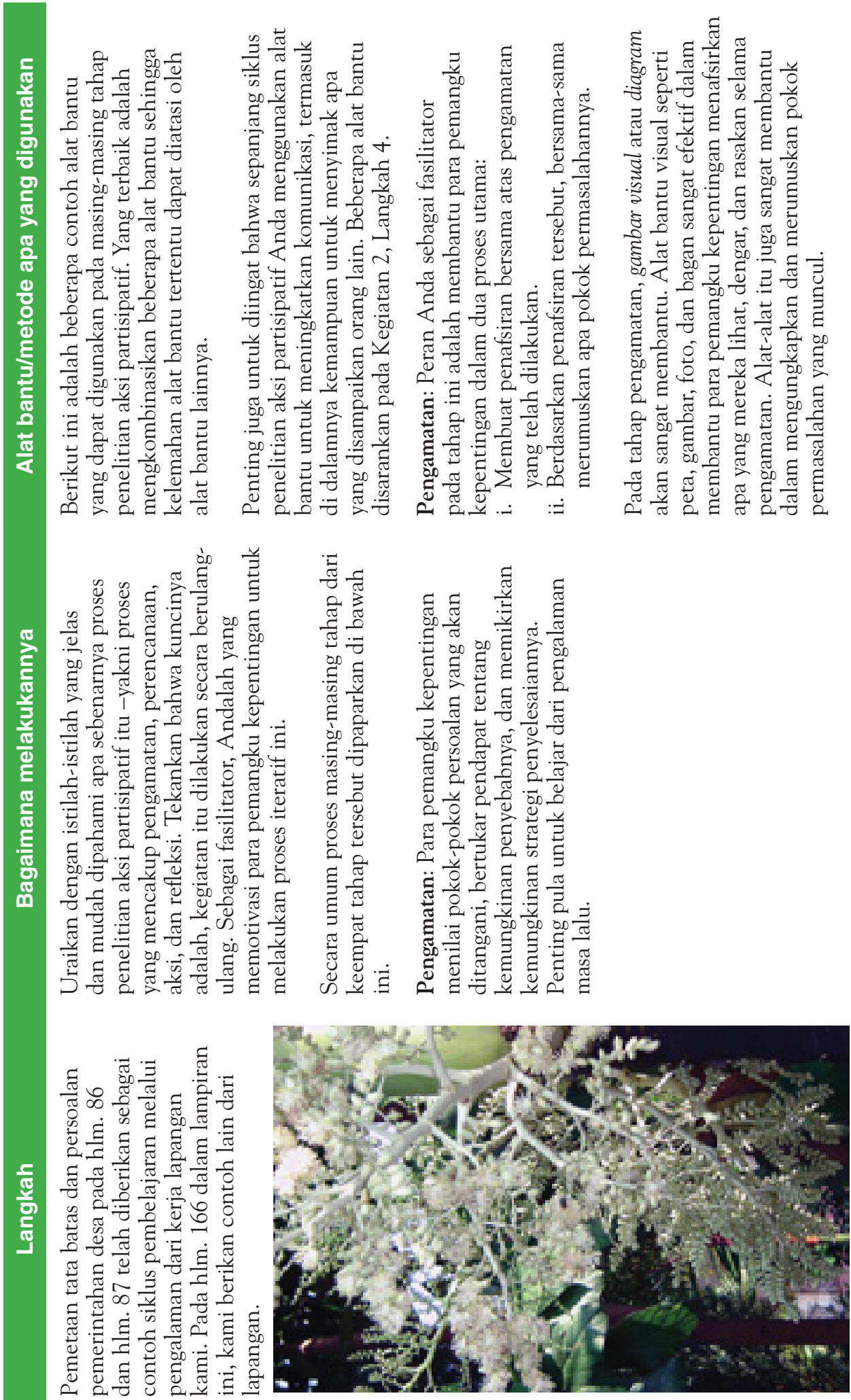


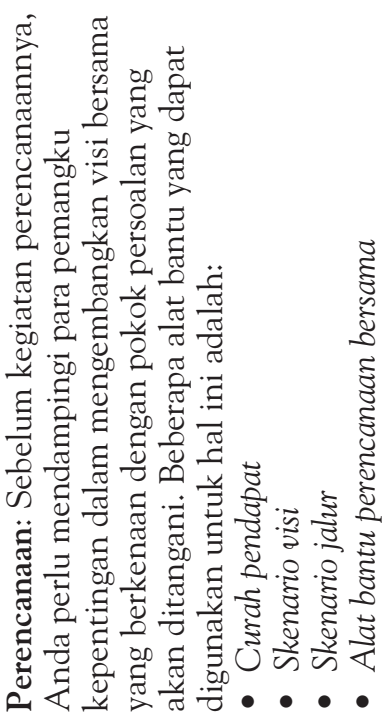

퓸

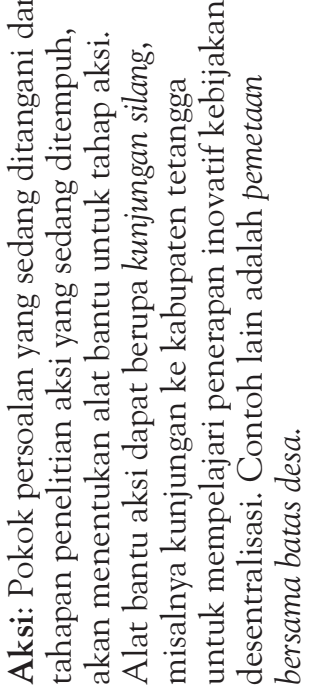

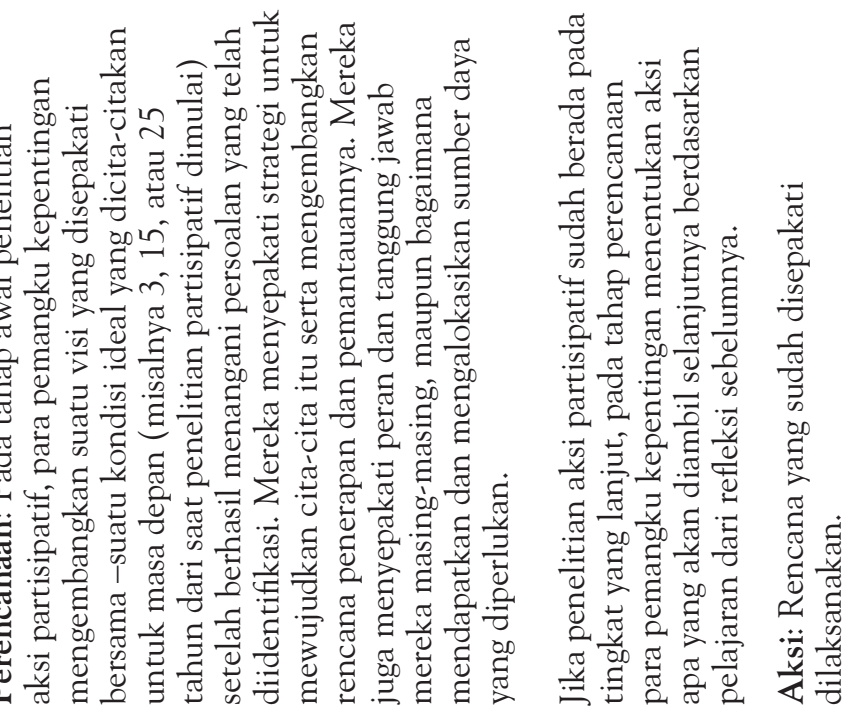

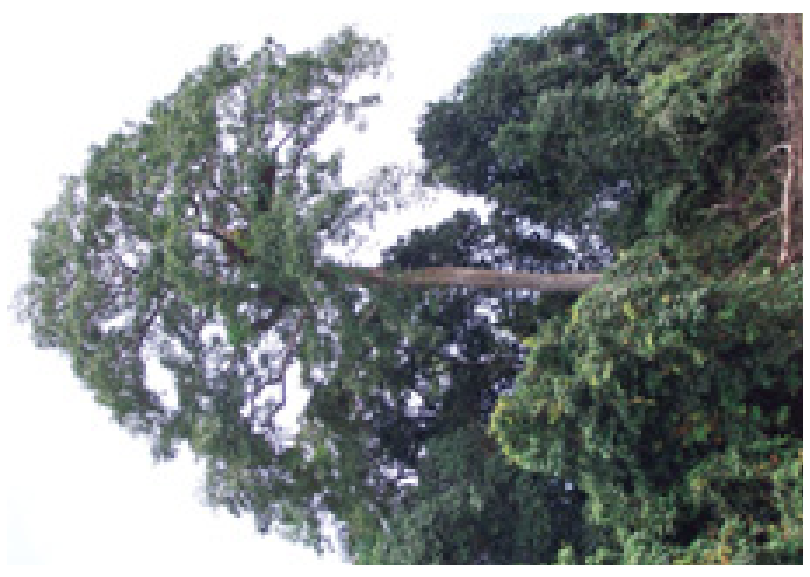




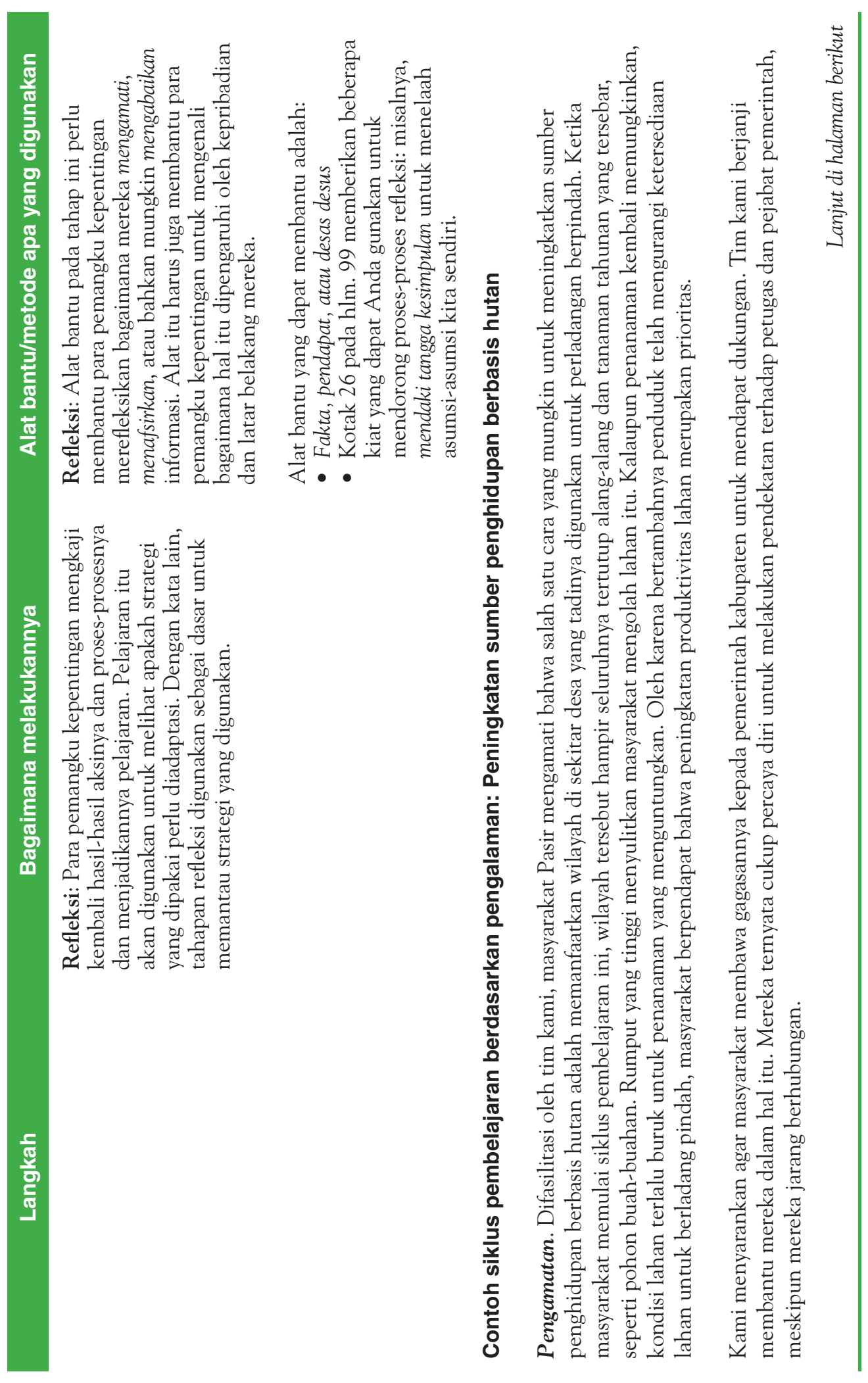




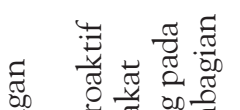

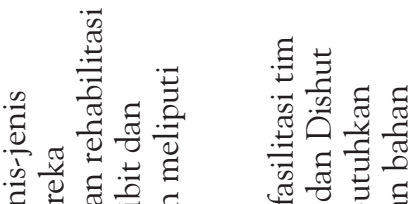

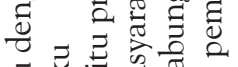

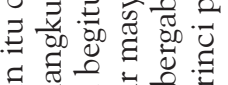

ฮี ฮี

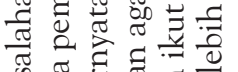

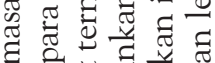

氙䒕

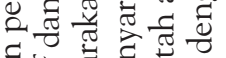

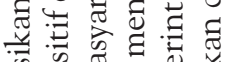

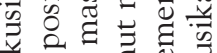

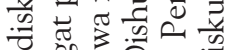

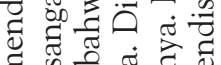

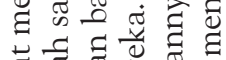

䒕苋苛䒕

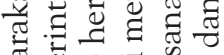

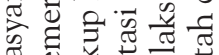

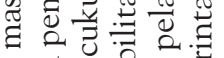

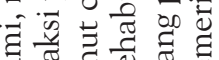

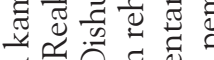

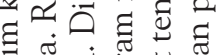

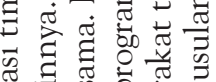

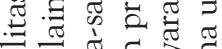

疍

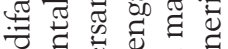

o.

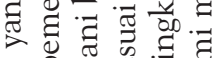

๙

त्ञ

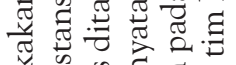

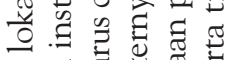

프 త్త

क.

ปี

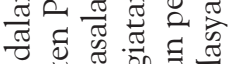

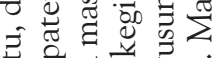

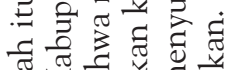

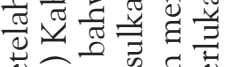

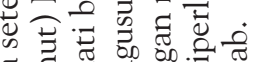

$\frac{\sqrt{2}}{\frac{10}{10}}$

ส

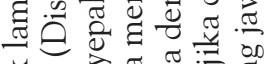

光

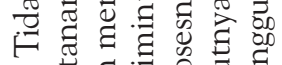

-

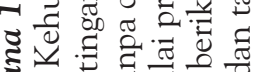

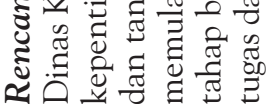

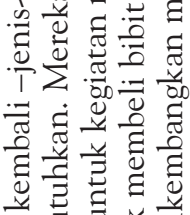

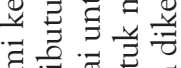

艺

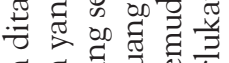

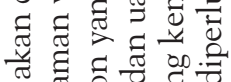

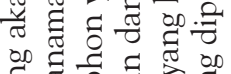

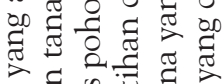

సี

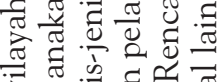

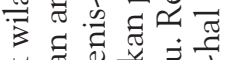

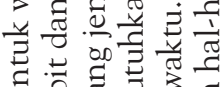

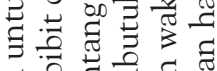

范

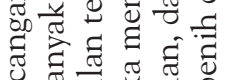

đٓ

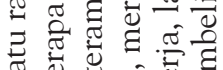

की

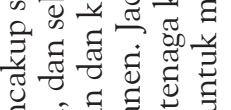

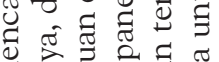

छ

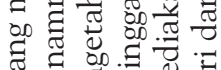

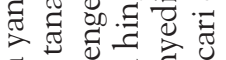

䒕苋

Uี

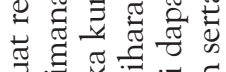

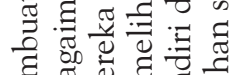

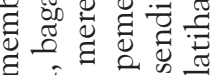

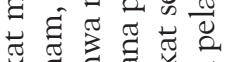

䒕芯芯芯芯

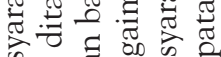

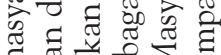

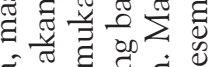

ॠీ

๘

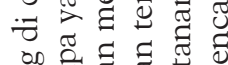

o

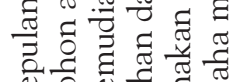

要至矛

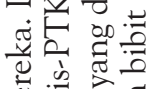

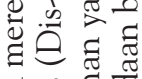

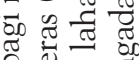

를

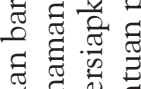

芯芯

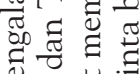

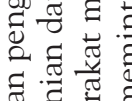

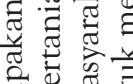

芯氙 离志

$\Xi \approx \pi$

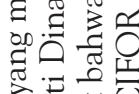

㐘苛

苍这䨌

छ

क

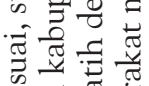

出 $=\frac{\pi}{0}$

赵苋芯

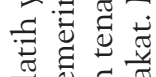

记

ज记

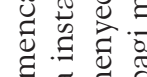

元

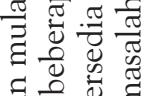

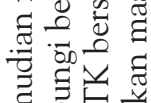

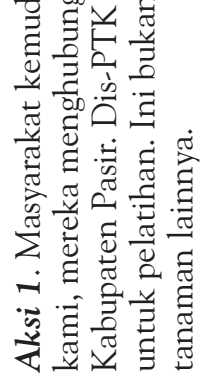

芩

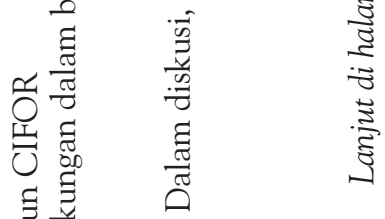

穵茎 章

范营

ॠี छ

芯芯吉

敢步

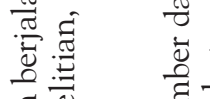

त्ञ

च

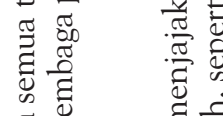

क छ्ठ है

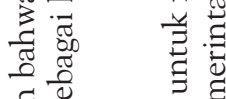

चٓ

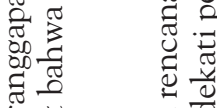

芯芯

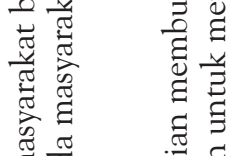

造 $\frac{\pi}{0} \frac{\pi}{0}$

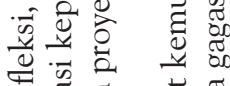

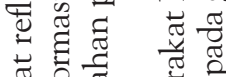

荧.

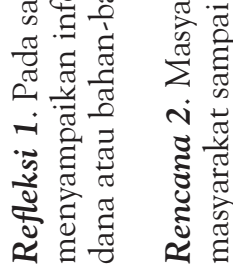




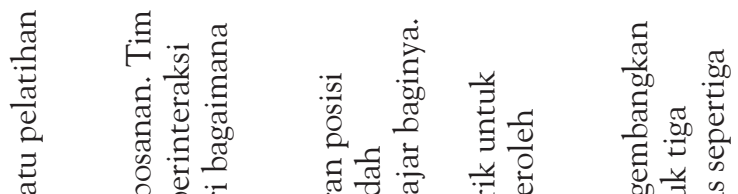

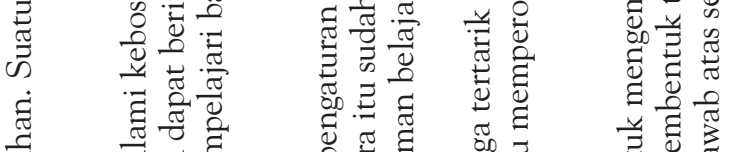

苛

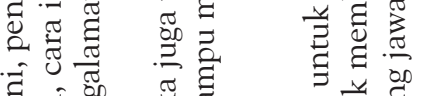

㟧

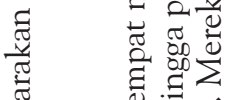

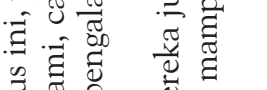

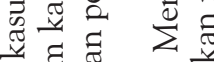

क्ष

है

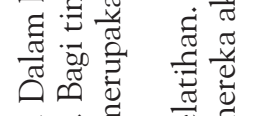

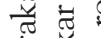

空就

बं

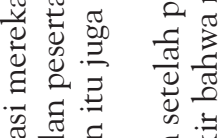

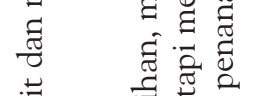

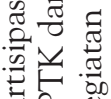

证 $\frac{\pi}{\pi}$

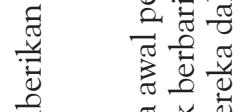

क्ष

$\frac{\pi}{\pi} \frac{v}{3}$

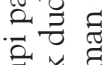

를

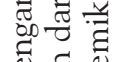

ํㅡㄹ름

:

氜芑志

吾苋

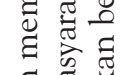

뜰

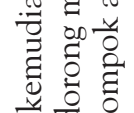

可

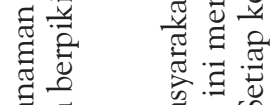

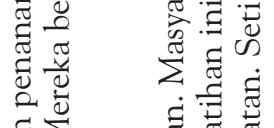

宽苋

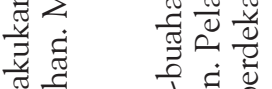

胥 $\frac{\pi}{0} \frac{\pi}{0}$

过

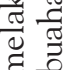

ฮี

离章

空

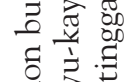

䒕

范

烈

द्वे

炃范范

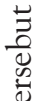

范芯

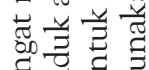

远

츰

등 웡

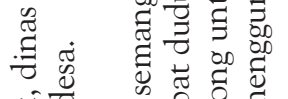

氖可

표

这.

대융

올 สี

苋范

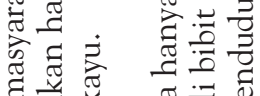

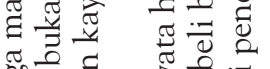

준

홍

然

政

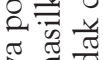

글

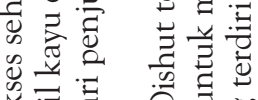

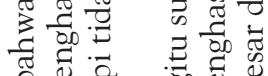

要

可

$\frac{\sqrt{15}}{\frac{10}{50}}$

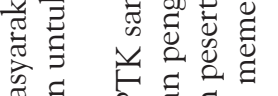

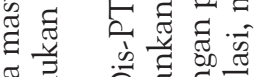

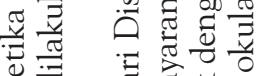

v

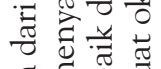

㱐

䨌

$\div \div \widetilde{\pi}$

들

잉

ธo

도욤

氜 $\frac{0}{0}$

离

政

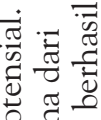

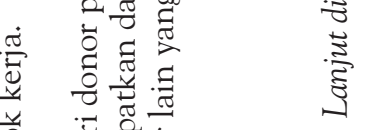

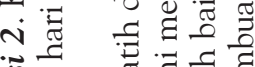

政

ㄴ.

윰

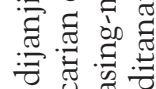

on

है

.$=\frac{\pi}{0} \pi$

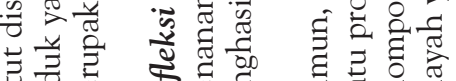

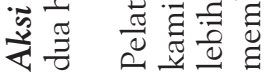

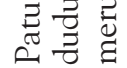

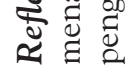

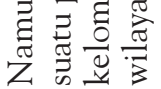

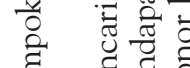

过

政

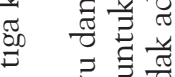

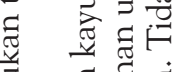

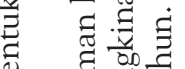

든

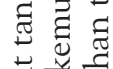

응

更

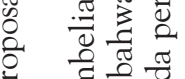

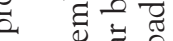

变

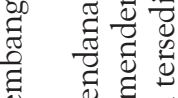

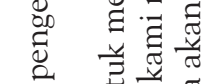

苟党

क्ष

空.

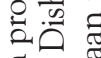

๘

so 듀 즘

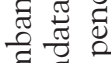

品 颉

苋苋

苛苛

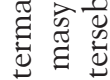

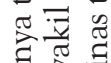

要

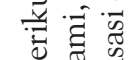

$\rightarrow \frac{\pi}{0}$

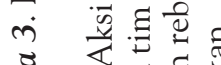

है

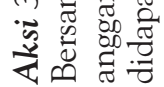


జี

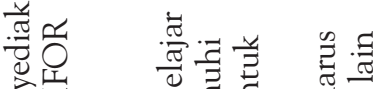

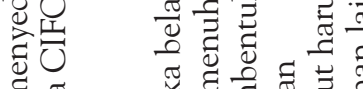

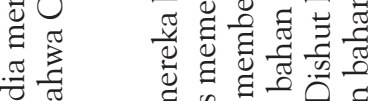

चु

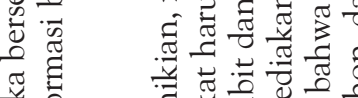

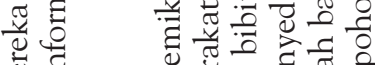

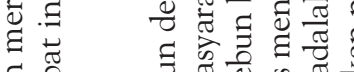

苞

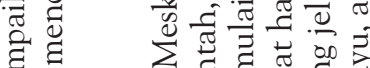

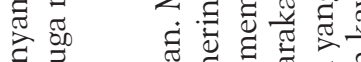

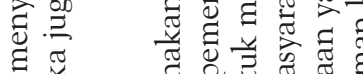

ש

苋

त्ञㄹ.

帘

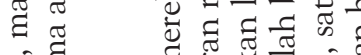

ब $\frac{\overrightarrow{3}}{2}$

बक

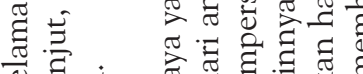

ڤే छ.

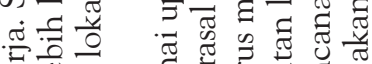

एष्ठ

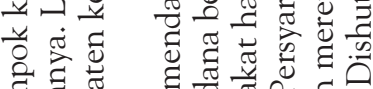

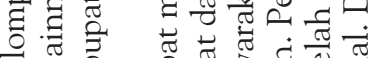

$\frac{0}{4} \frac{\pi}{3}$

范

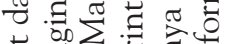

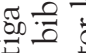

$\vec{z}$

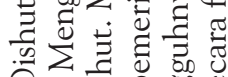

넌

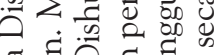

过

刍

总 $\Xi_{0} \cdot \bar{m}$

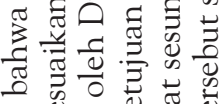

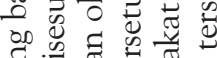

胥莞

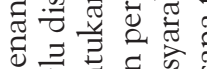

D. 


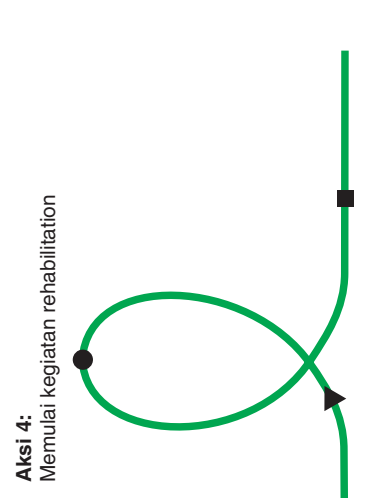

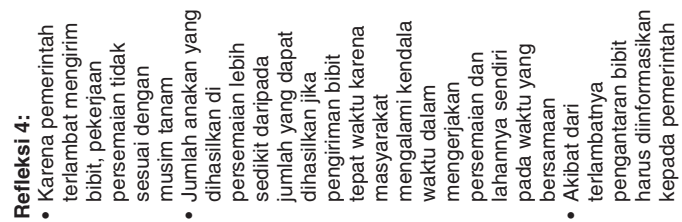

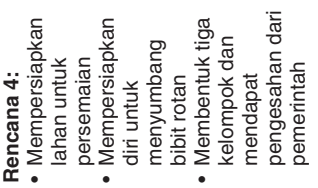

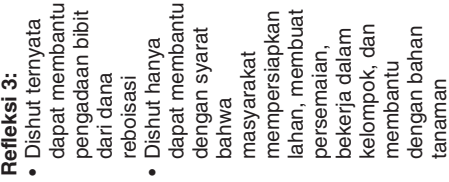

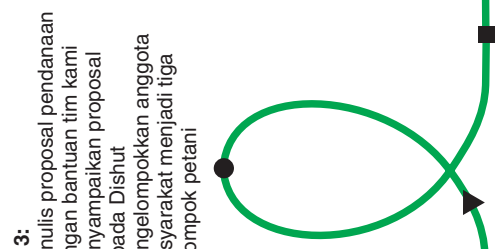

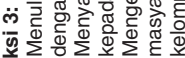

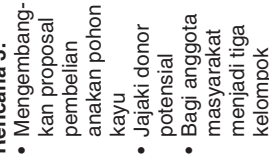

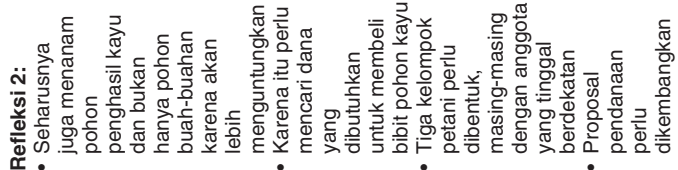

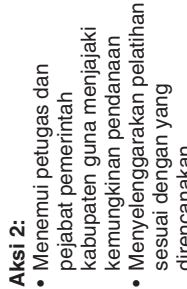

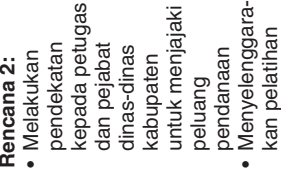

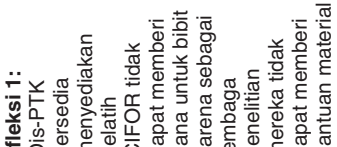

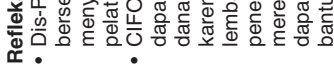

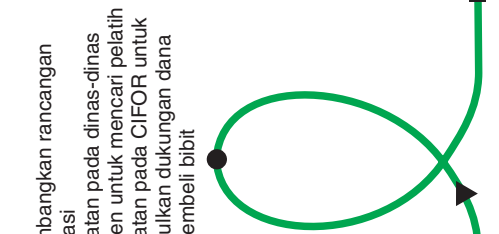

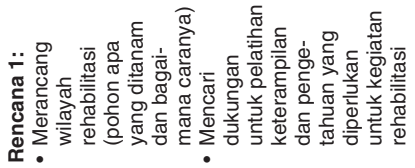




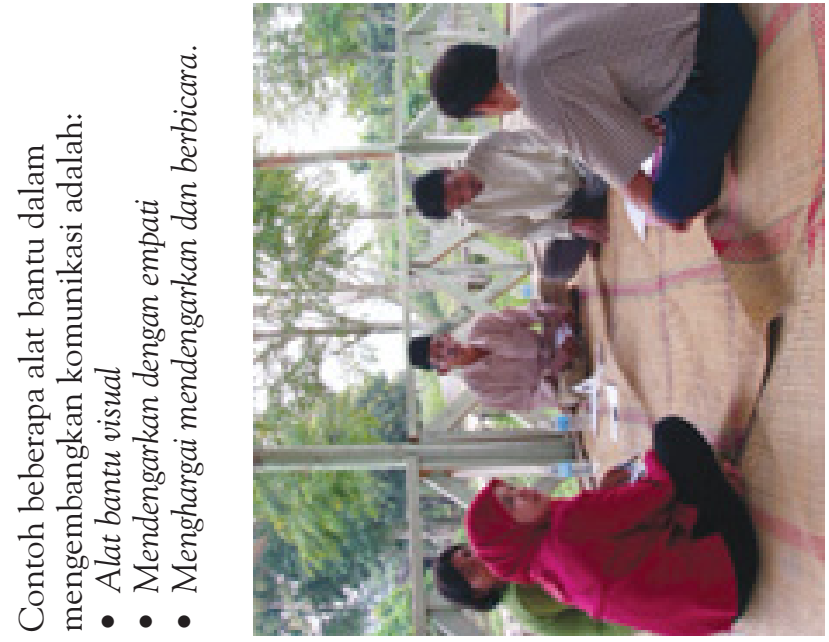

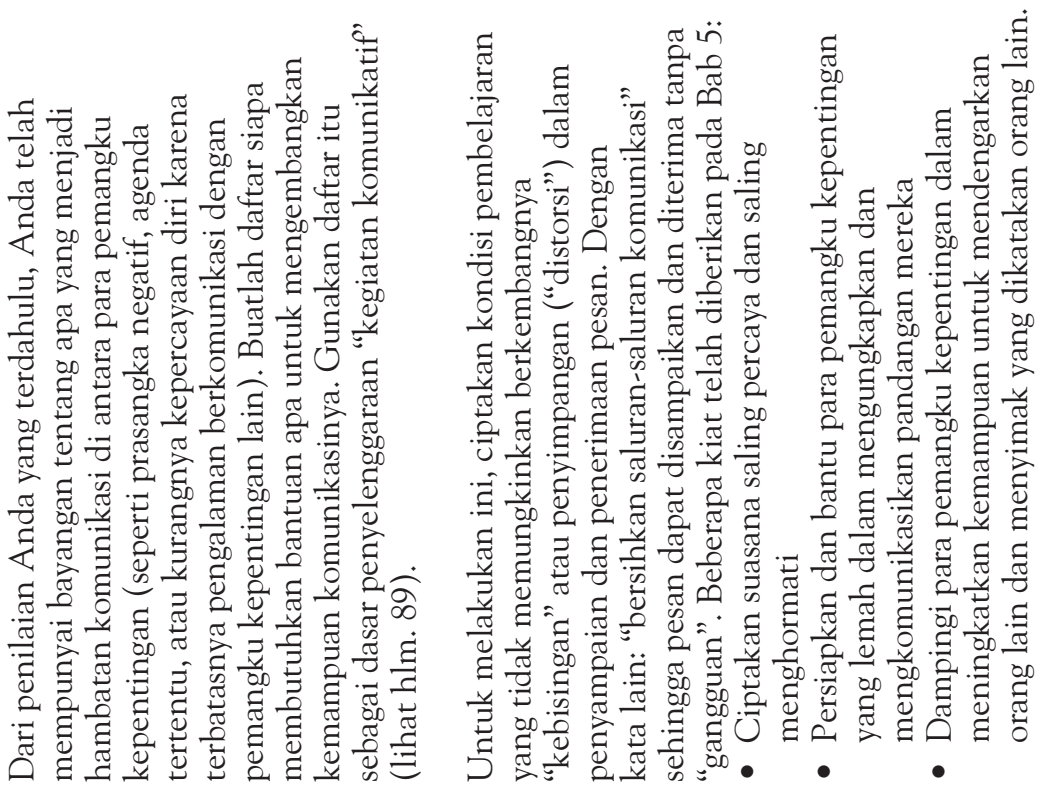
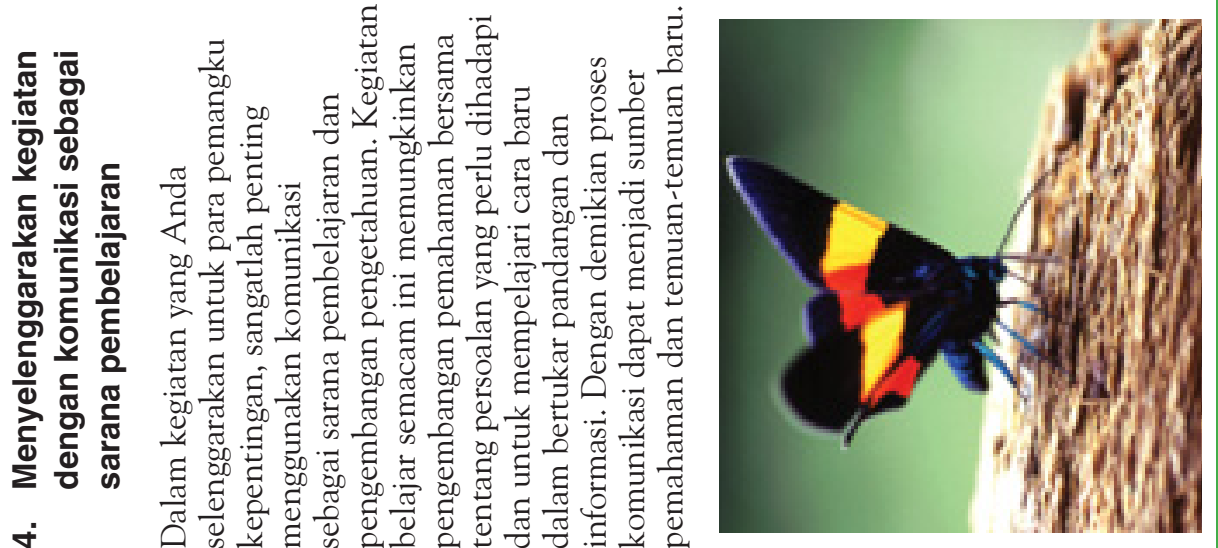


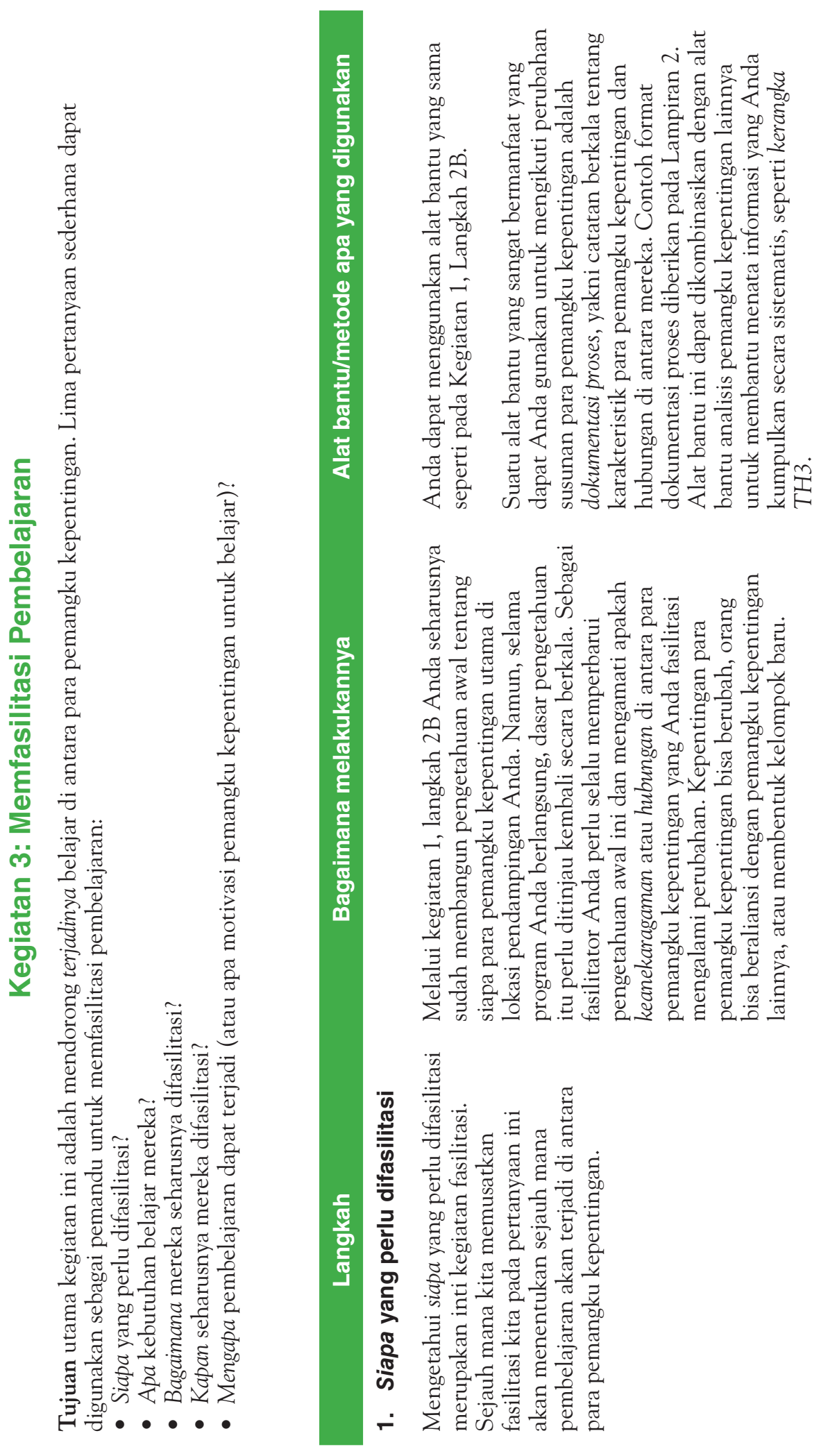



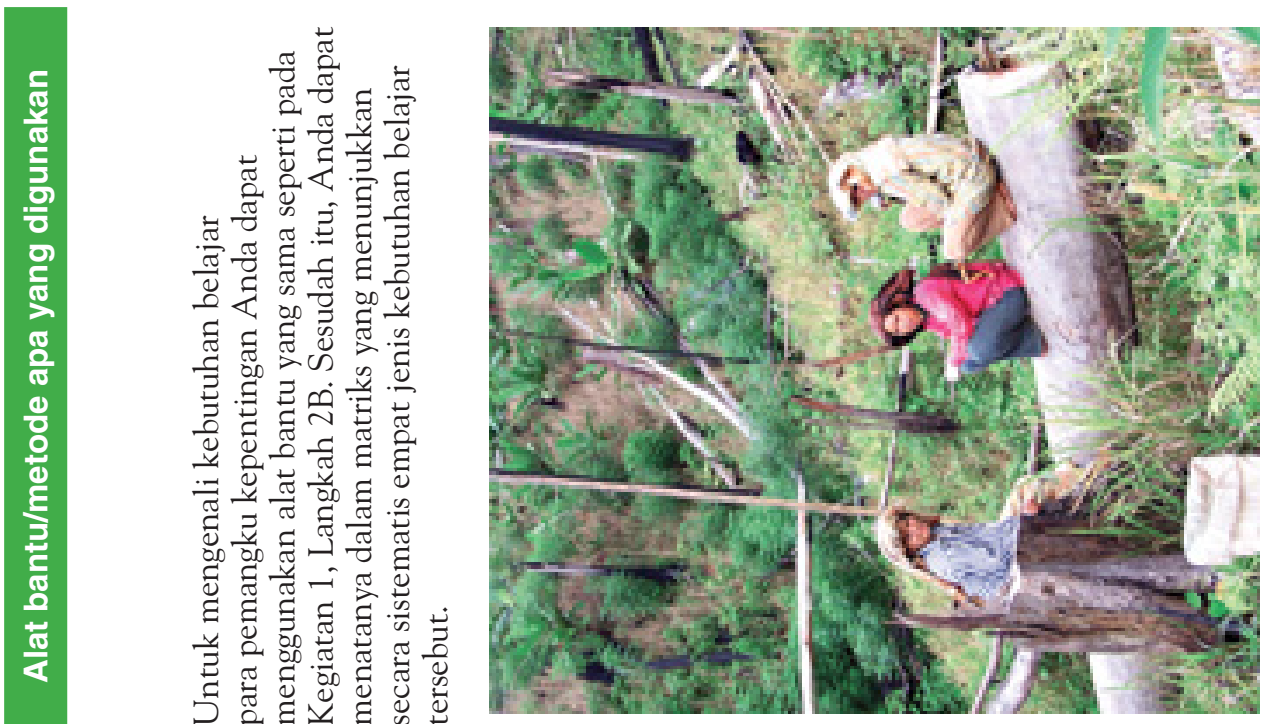

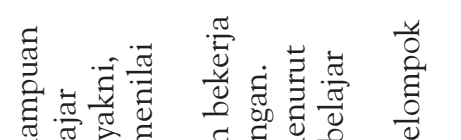

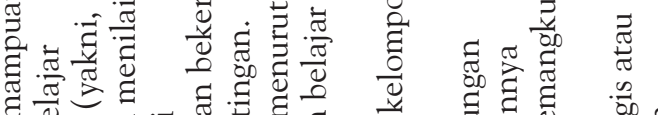

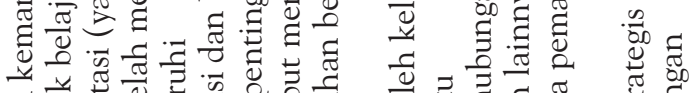

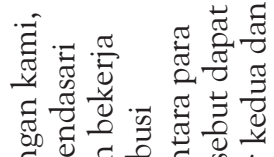

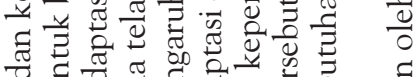

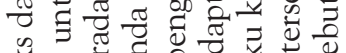

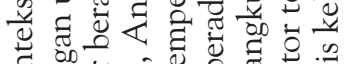

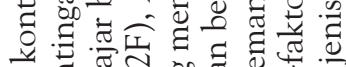

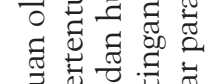

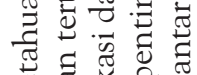

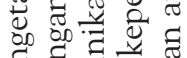

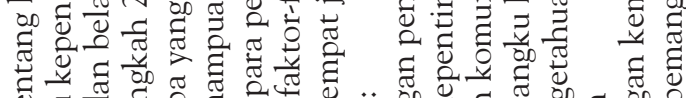

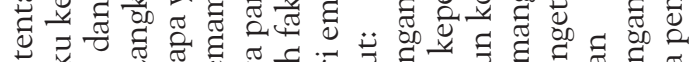

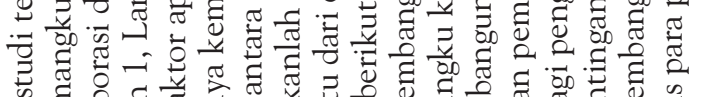

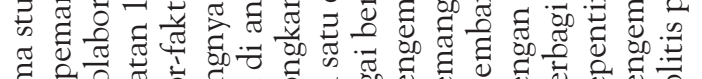

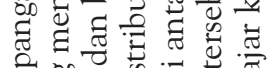

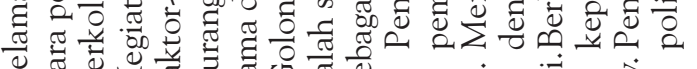

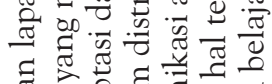

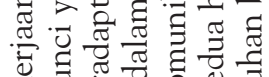

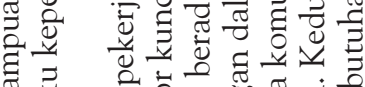

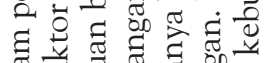

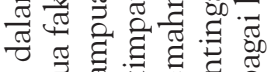

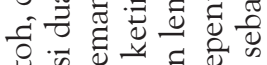

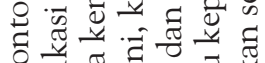

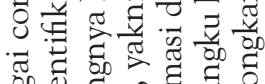

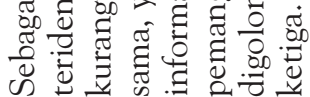
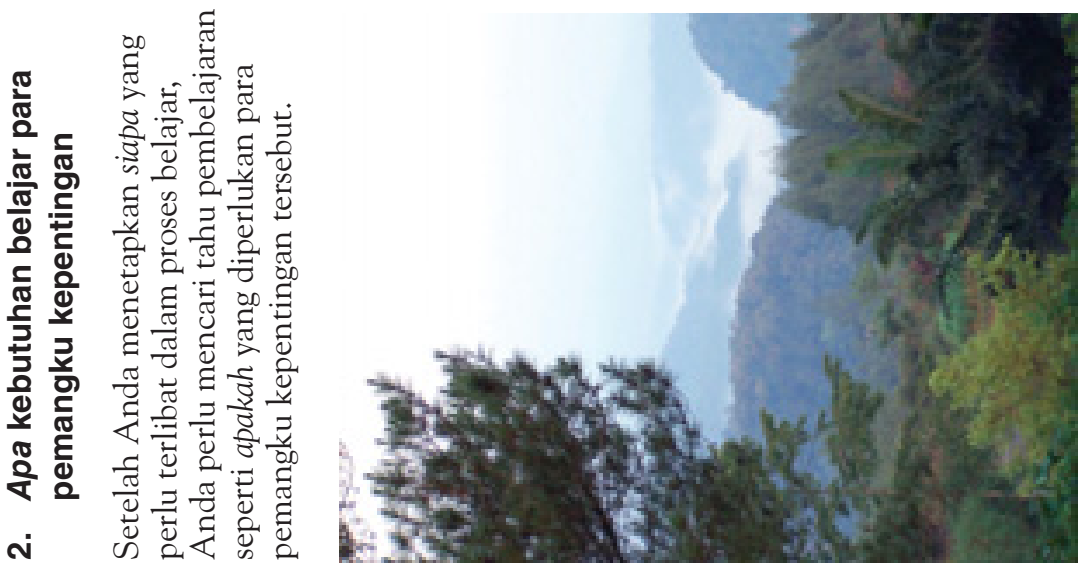

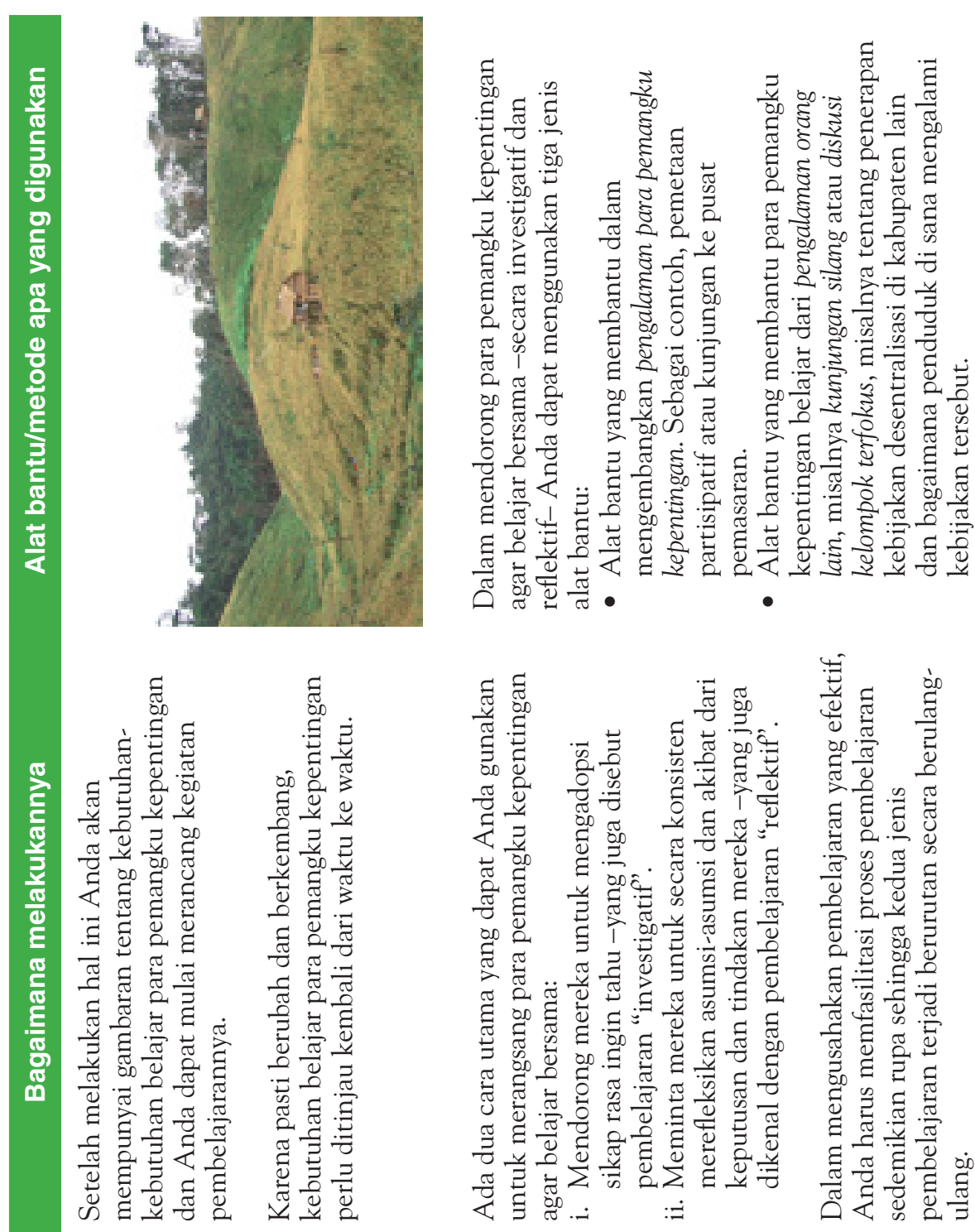

동
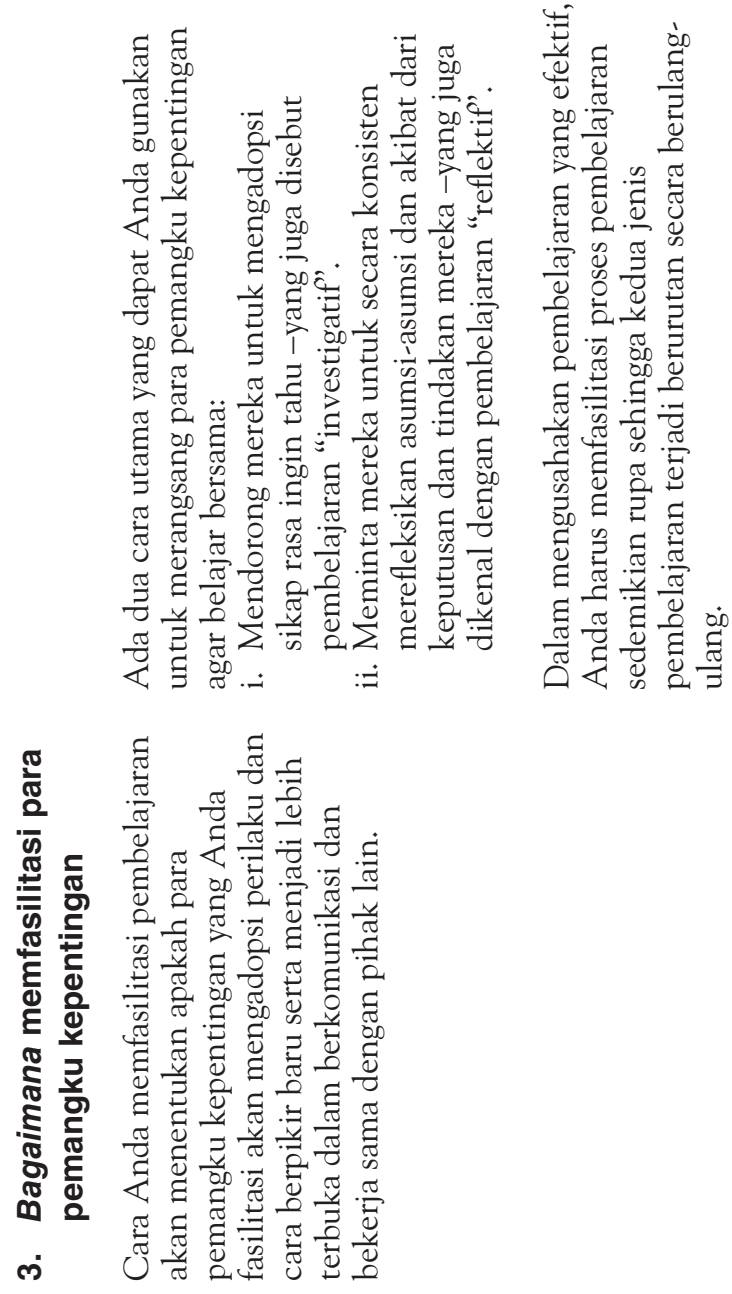
क्ष

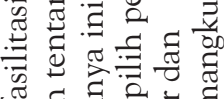

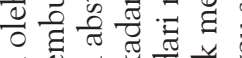

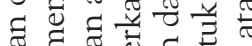

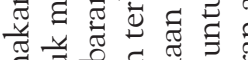

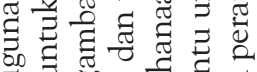
$.00 \%$ 西 $\Xi$

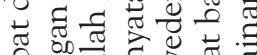

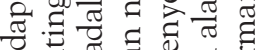

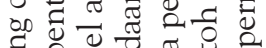
त्ञ शेष

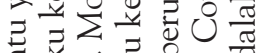

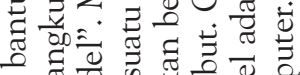
๘

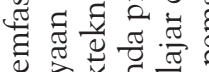

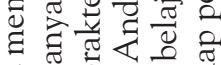
है

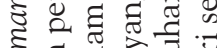

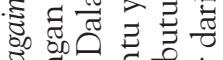
8 . op $\frac{0}{0} \cdot \vec{\pi} \cdot \frac{\pi}{\pi}$ 券㱐

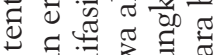

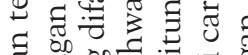

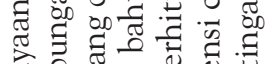

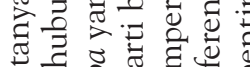

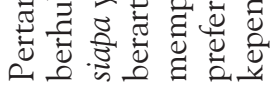
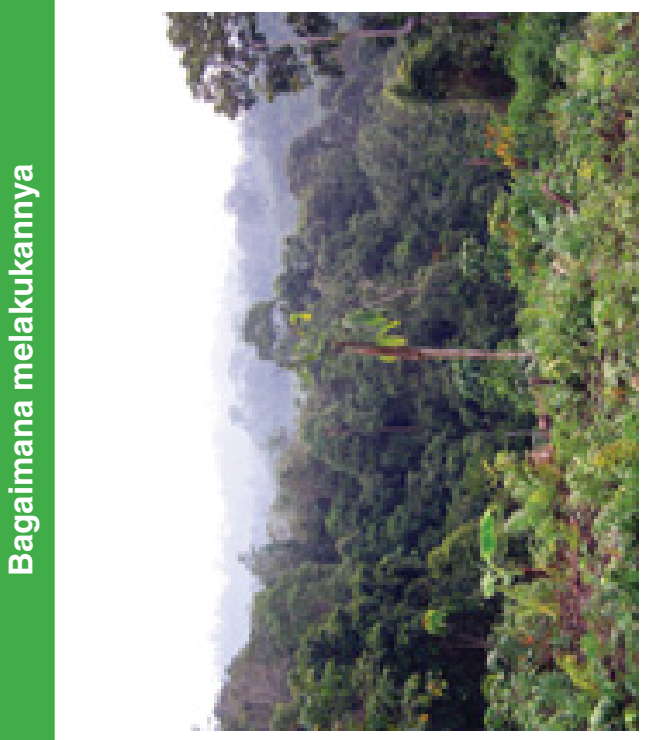

$\frac{\sqrt{10}}{\frac{10}{0}}$

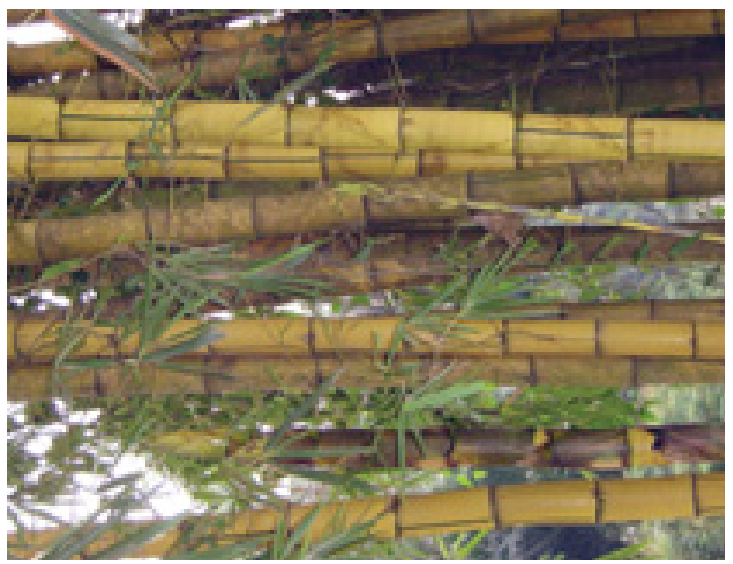

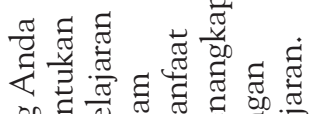

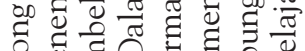

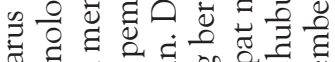

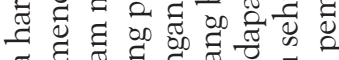
중 क्षै

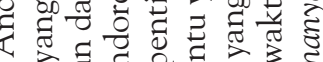
ร

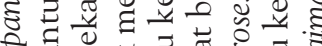

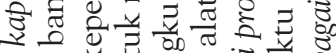
สี

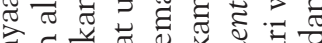
जี है

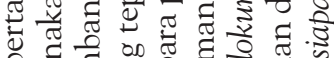
$\Xi \Xi$ ह 光

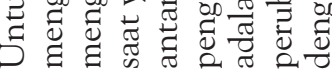
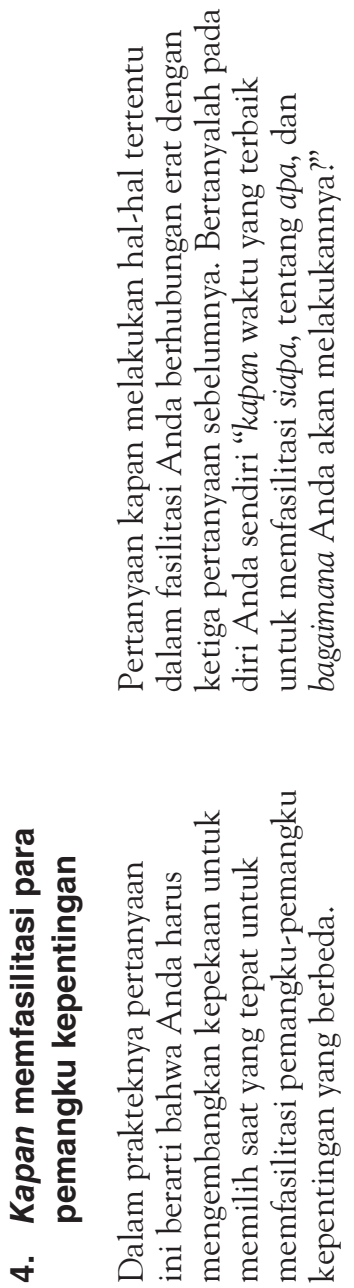


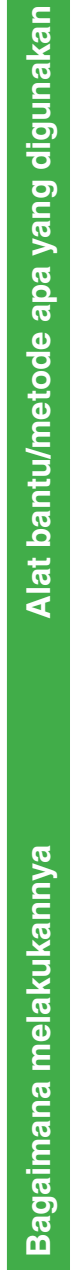

迹

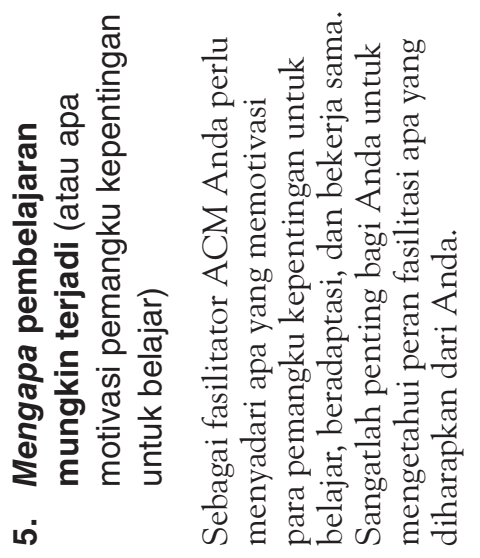

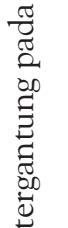

₹

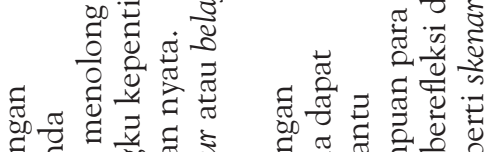

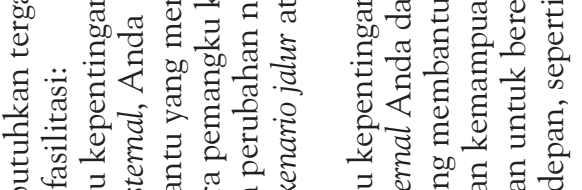

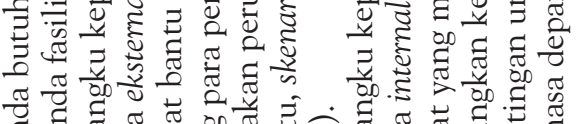

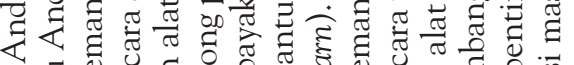
op

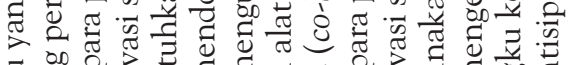

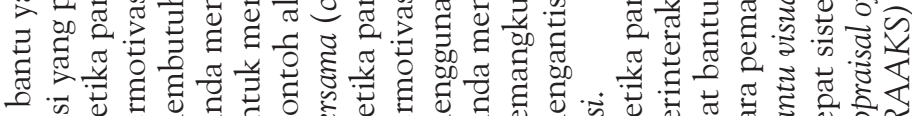

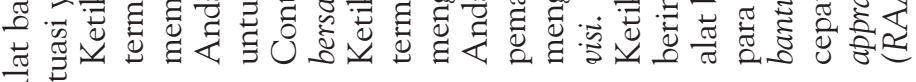
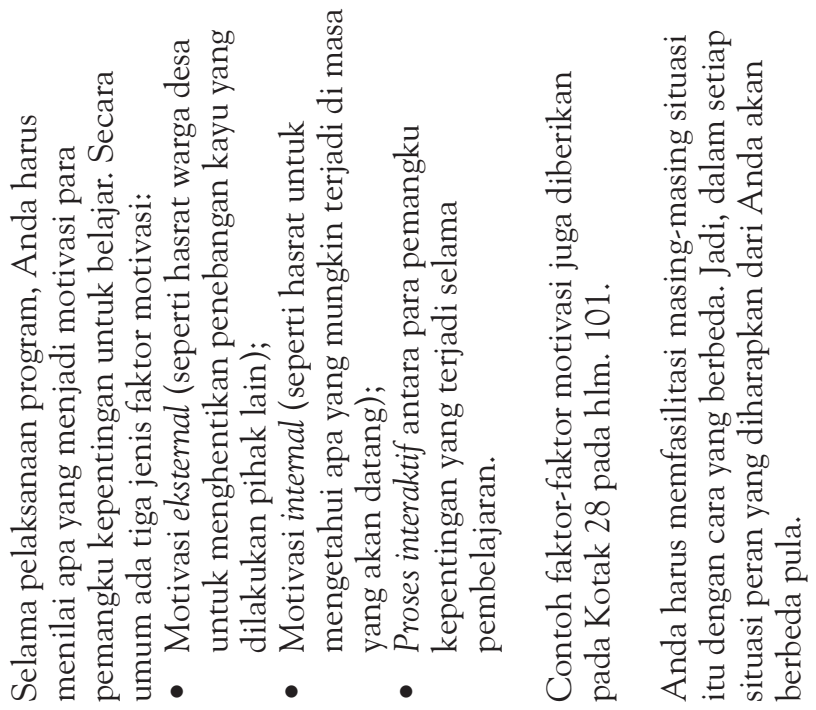

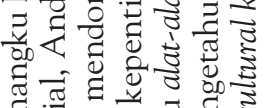
है:

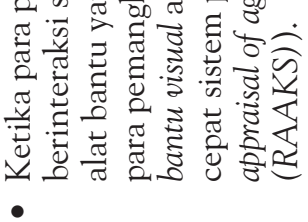

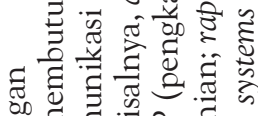

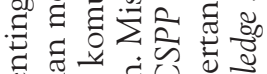

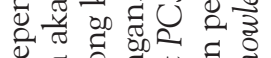

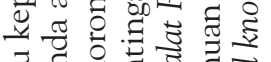

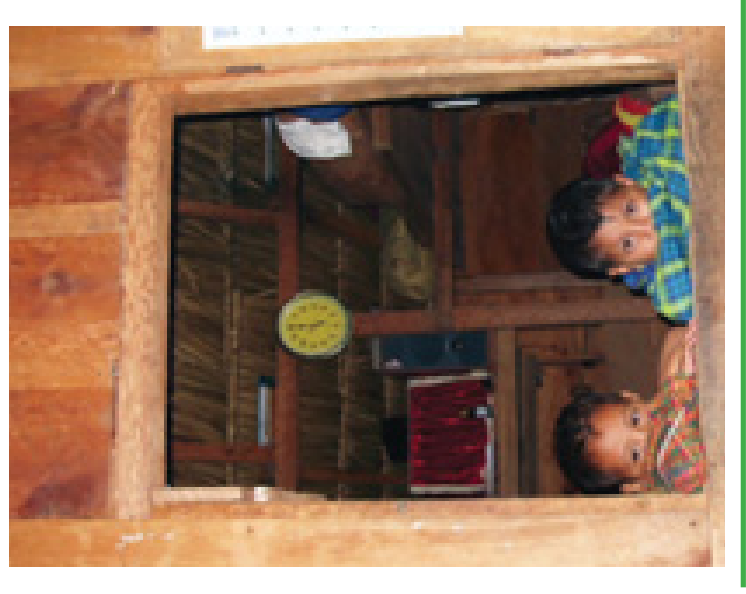




\section{LAMPIRAN 2}

\section{PERANGKAT ALAT BANTU ACM: SEBUAH CONTOH}

Lampiran 2 ini memaparkan suatu contoh perangkat alat bantu (tool kit) yang dapat digunakan dalam menerapkan ACM. Di dalam lampiran ini diuraikan berbagai alat bantu dan metode, masing-masing disertai penjelasan atau contoh tentang bagaimana menggunakannya. Di samping itu, diberikan juga sumbersumber acuan sebagai bacaan lanjutan bilamana Anda ingin lebih memperdalam penggunaan alat-alat bantu atau metode-metode tertentu. Anda dapat memakai perangkat ini sebagai contoh untuk mengembangkan perangkat alat bantu Anda sendiri yang dapat dikembangkan sesuai dengan kebutuhan fasilitasi Anda di tempat Anda menjalankan program Anda. Dari kumpulan alat bantu dan metode yang Anda temukan dalam perangkat alat bantu ini, akan terlihat bahwa suatu perangkat alat bantu dapat berupa sebuah kumpulan alat bantu yang sangat beragam. 


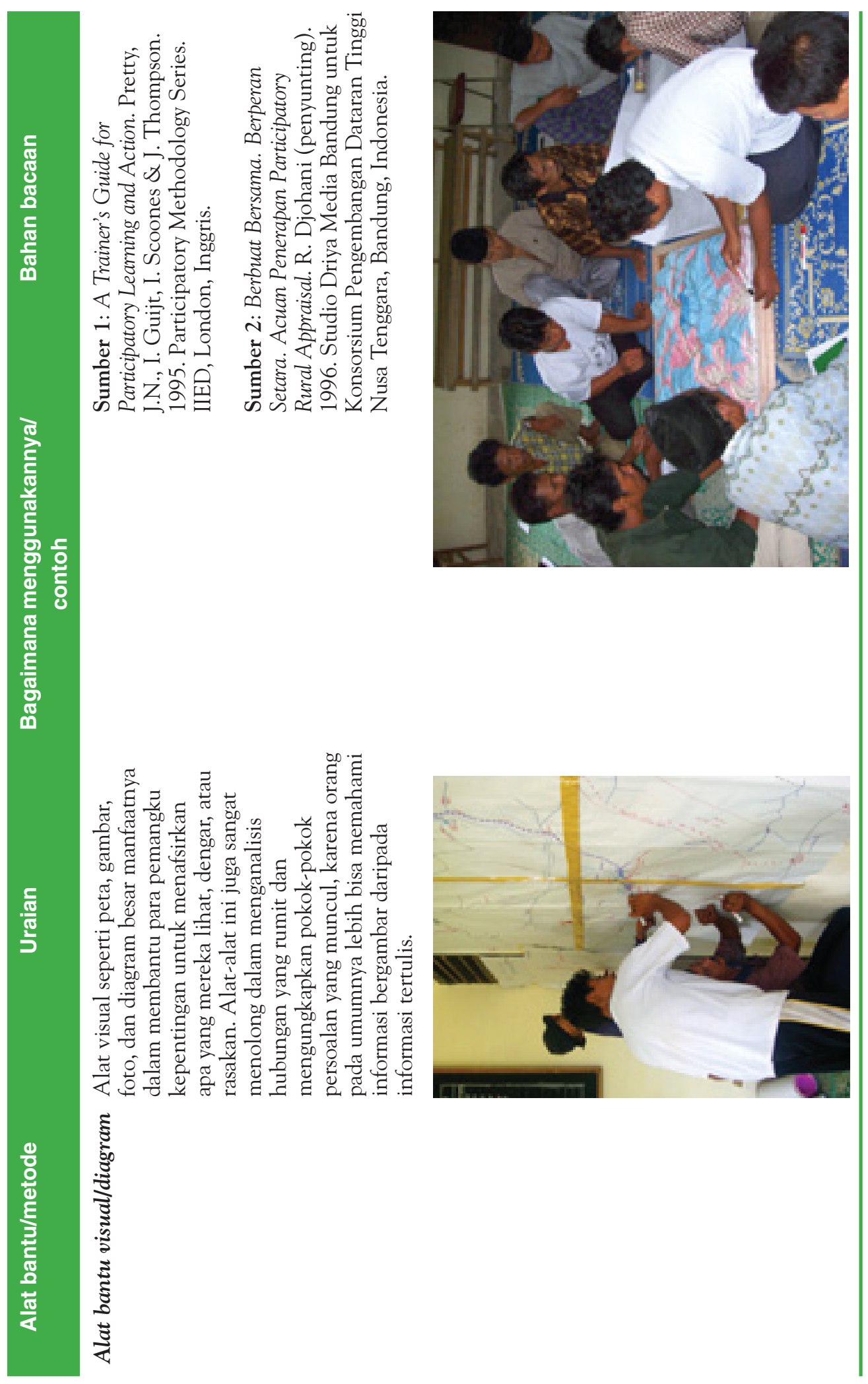




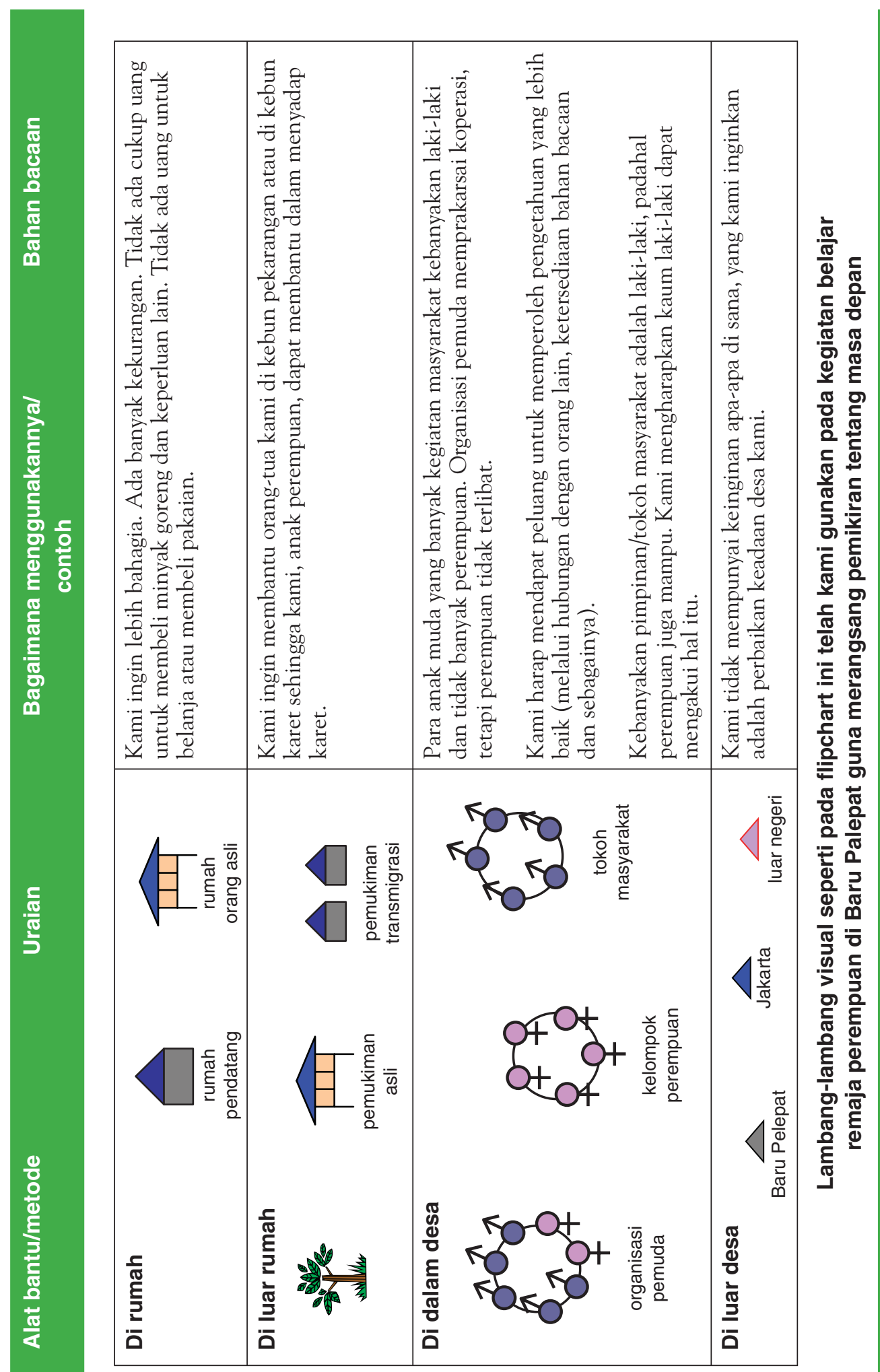




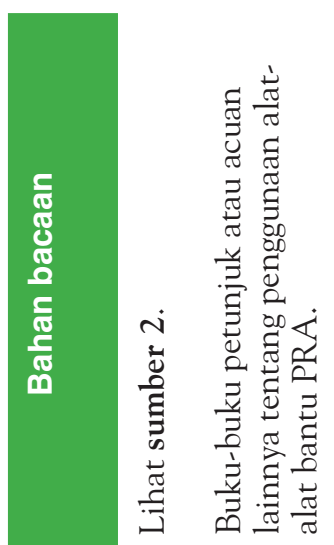

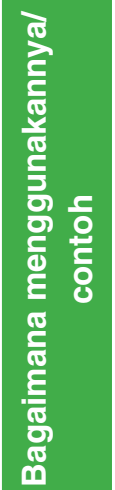

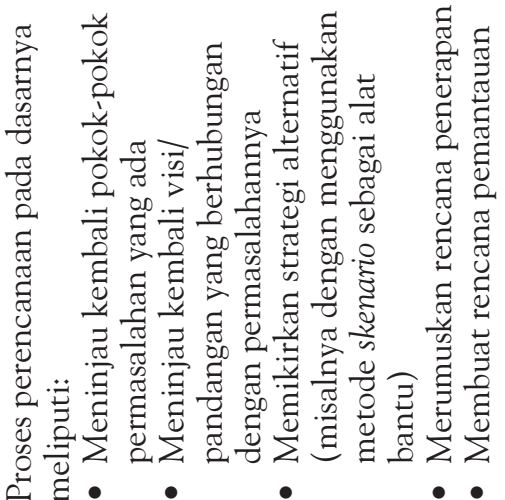

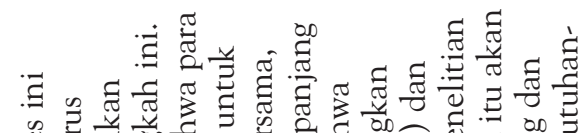

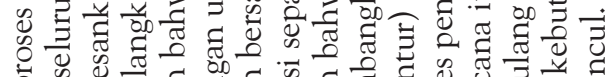

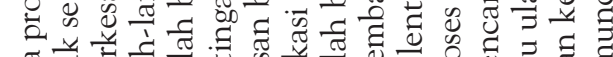

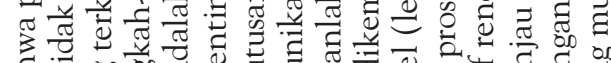
完

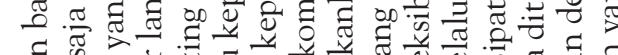

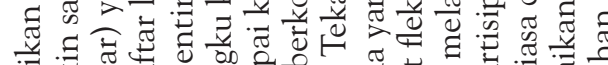

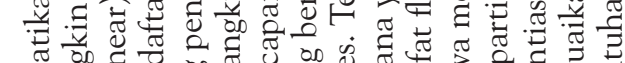

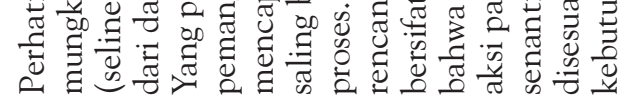

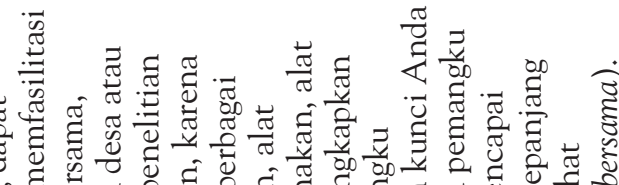

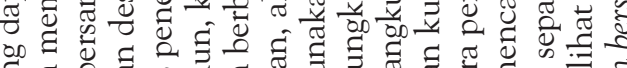

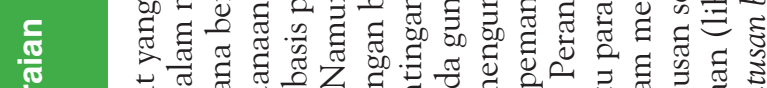

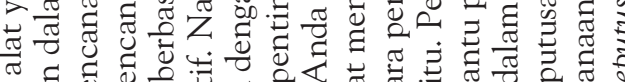

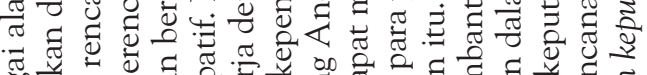

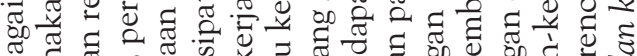

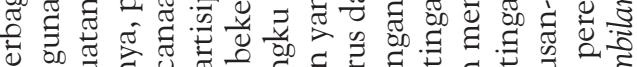

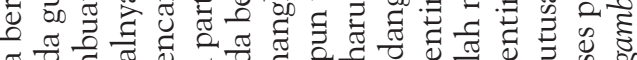

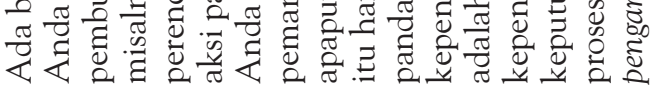

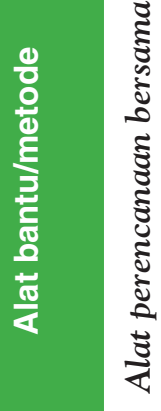

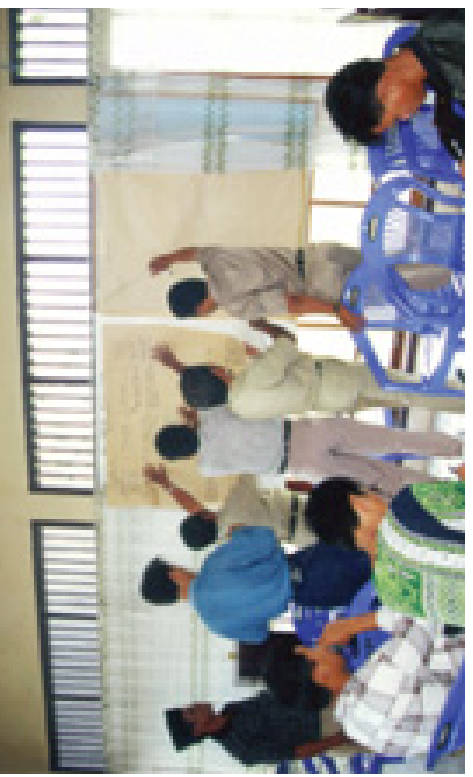




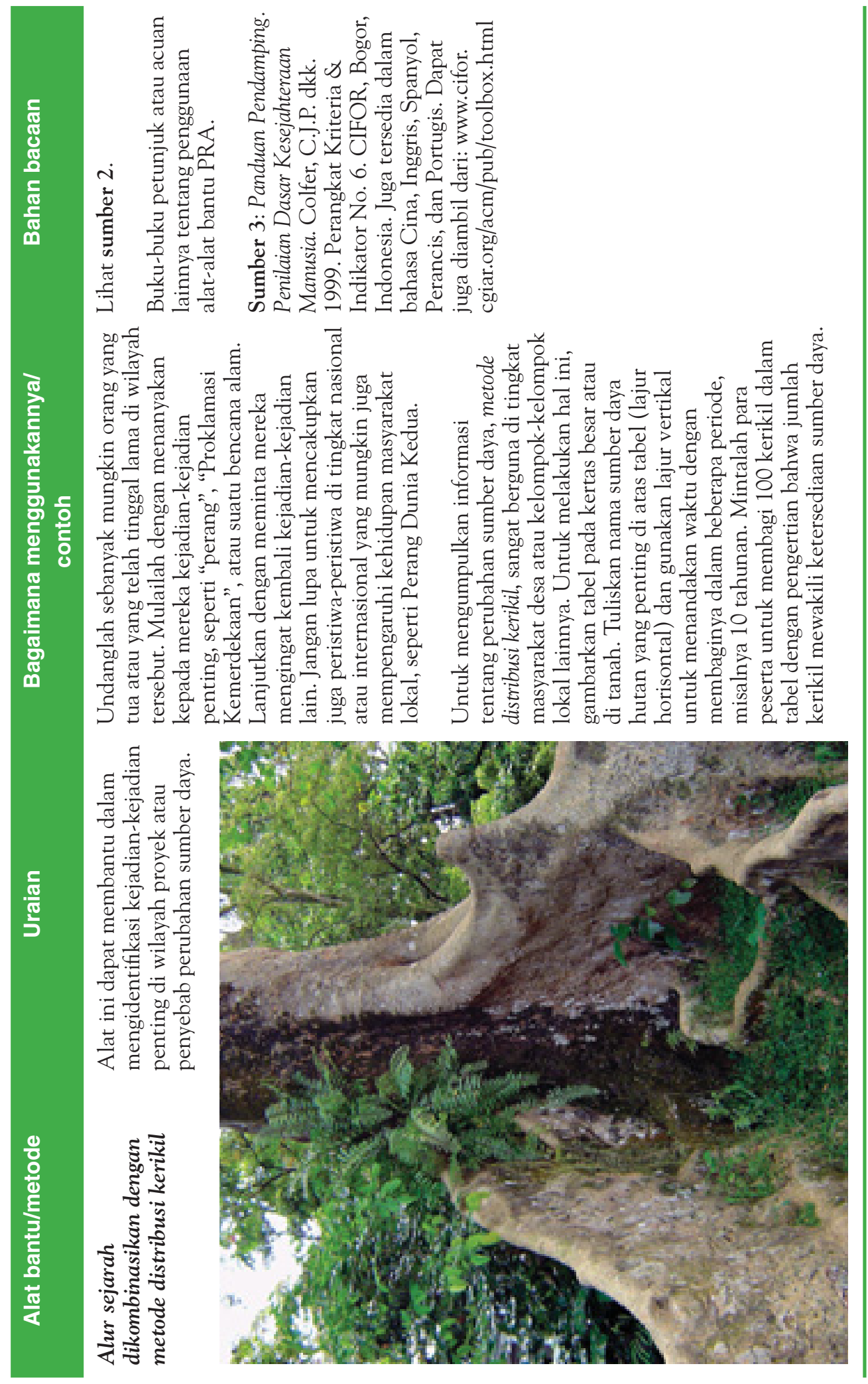



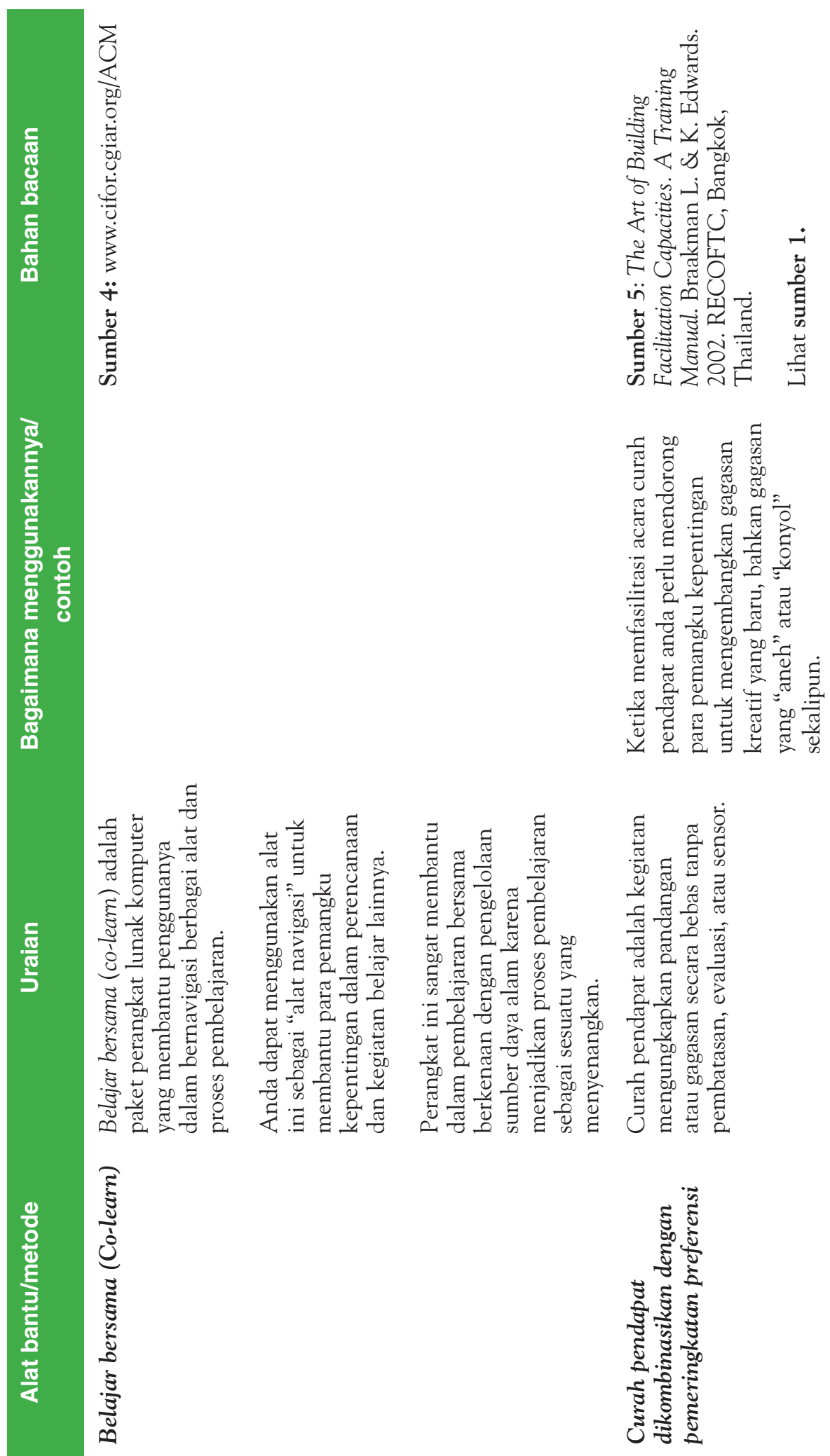

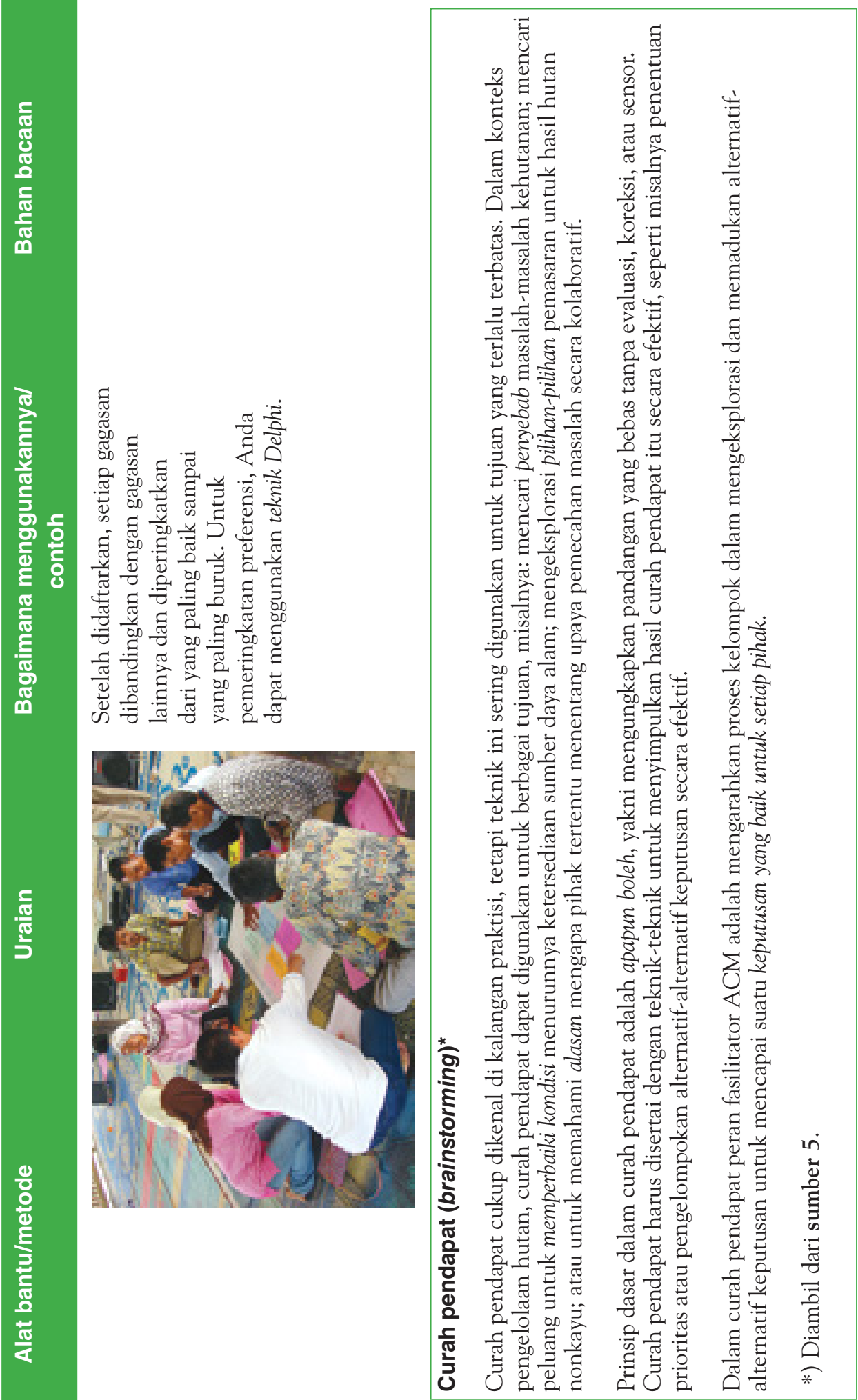

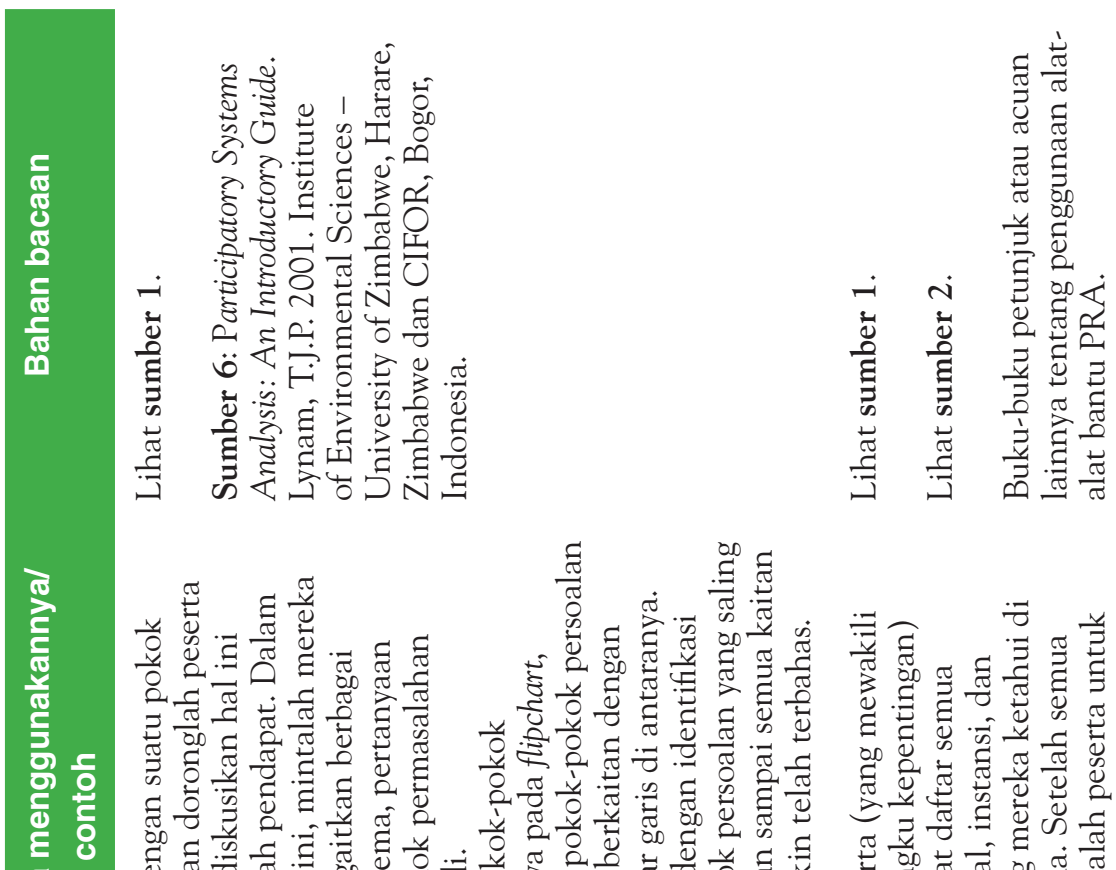

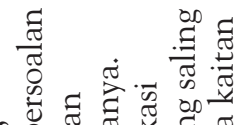

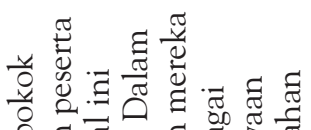

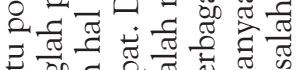

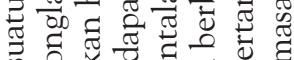

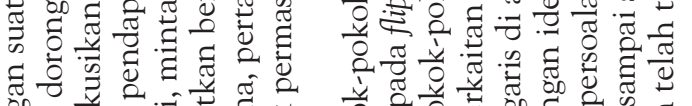

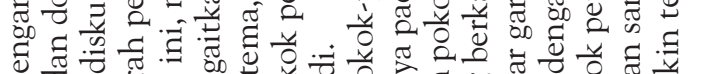

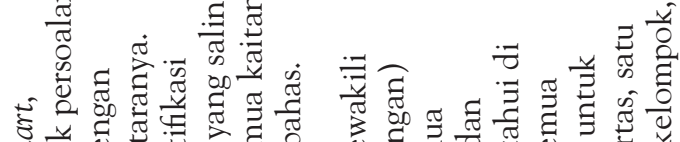
छั

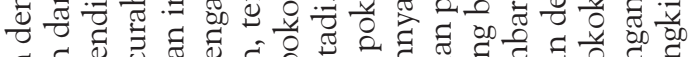

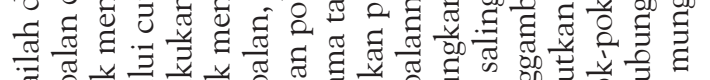

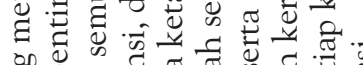

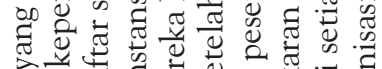
$\triangleq$

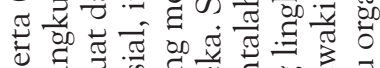

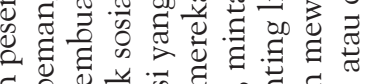

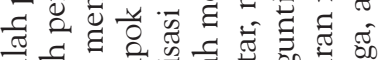

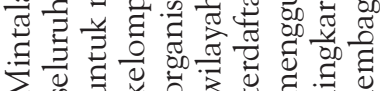

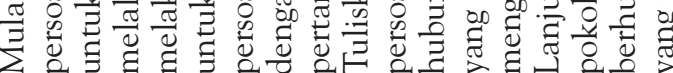
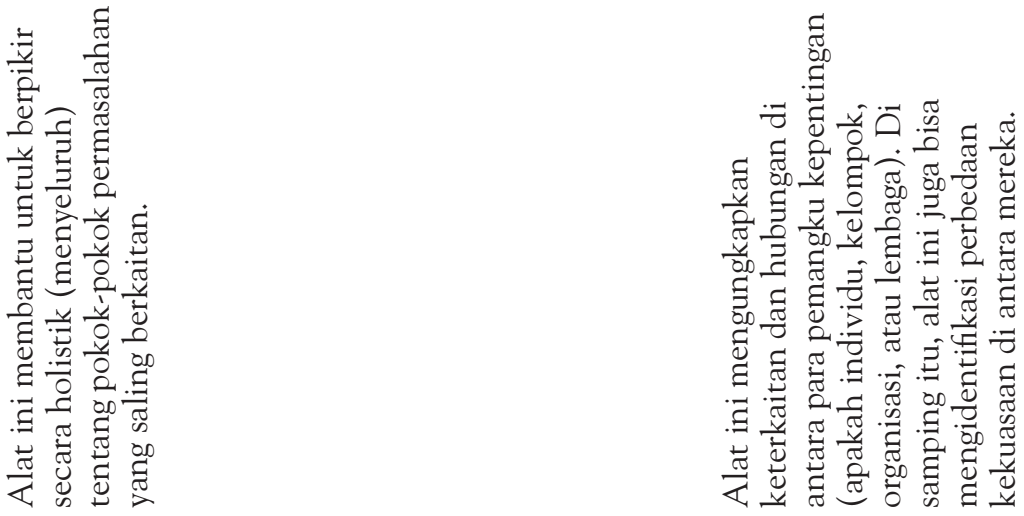

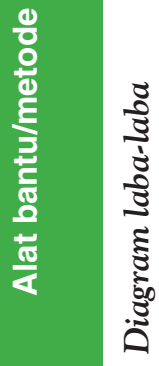

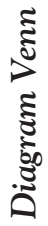




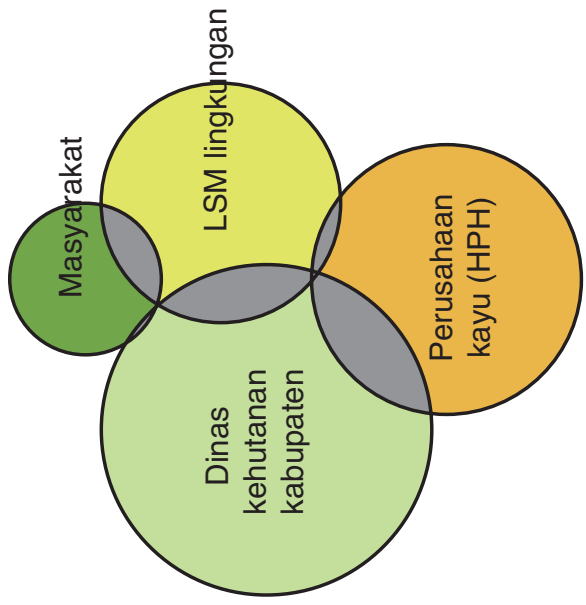

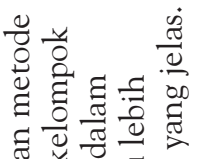

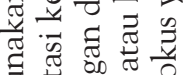

$\sigma_{0}: \Xi Z$

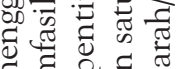

๖

\& $\quad \overrightarrow{0}$

때 क्षै

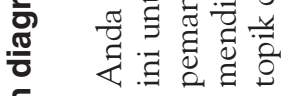

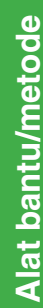

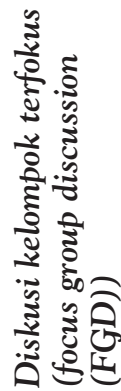



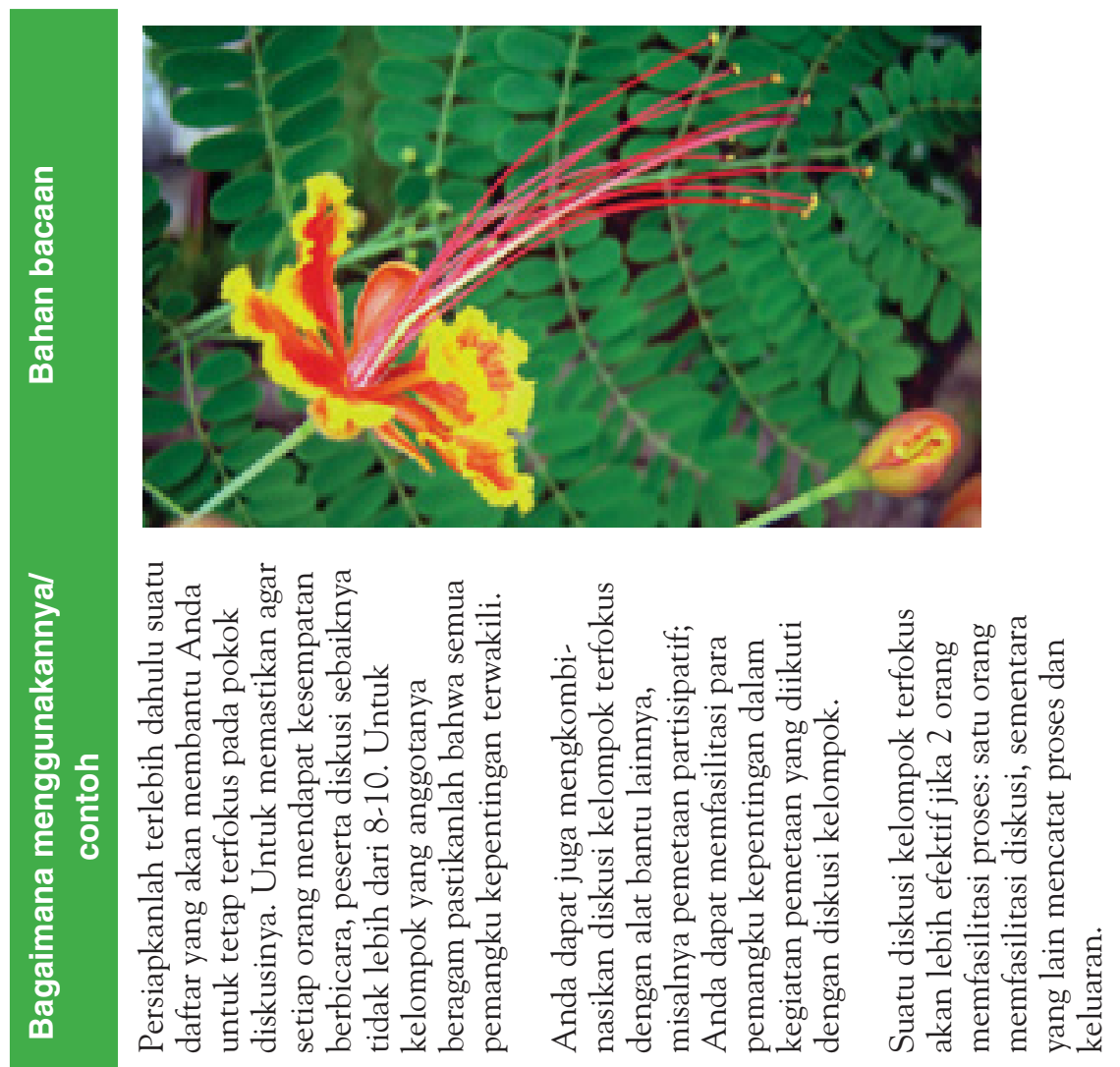

$\frac{\frac{5}{5}}{\frac{\pi}{5}}$

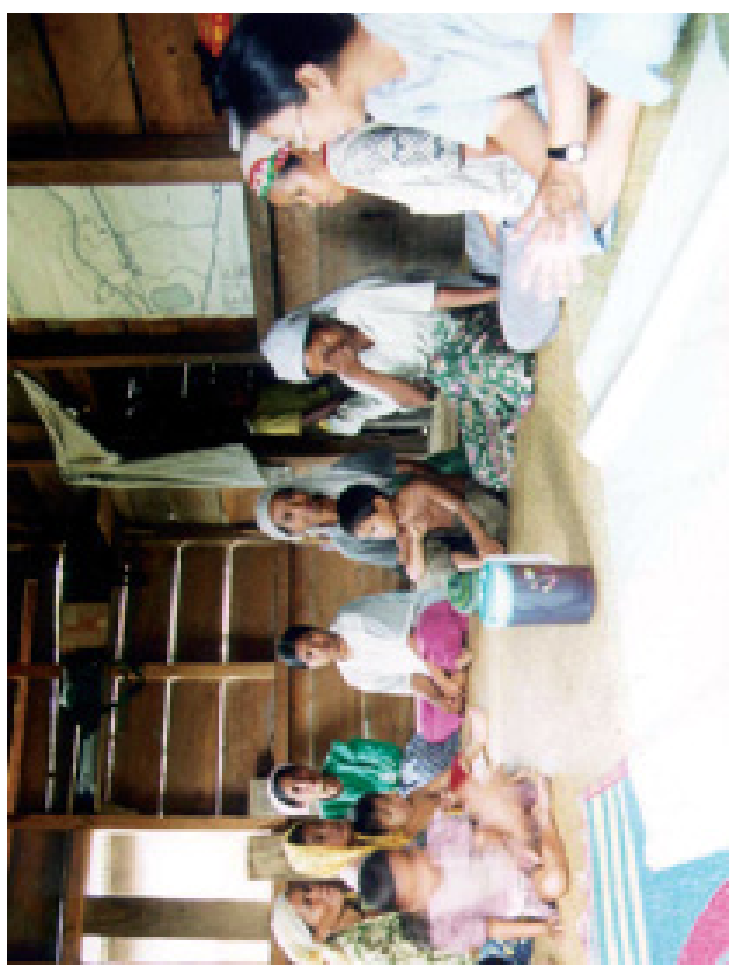




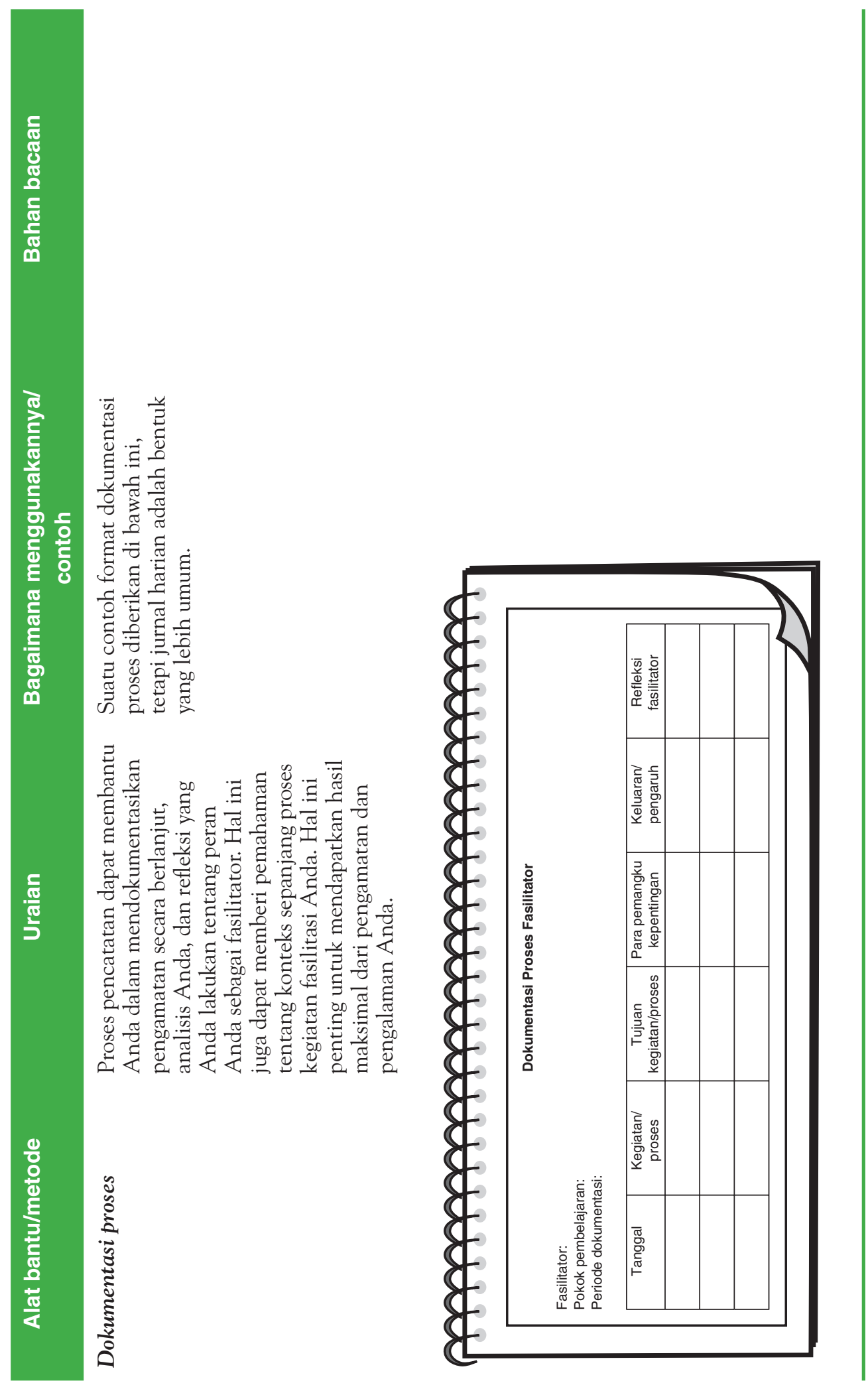



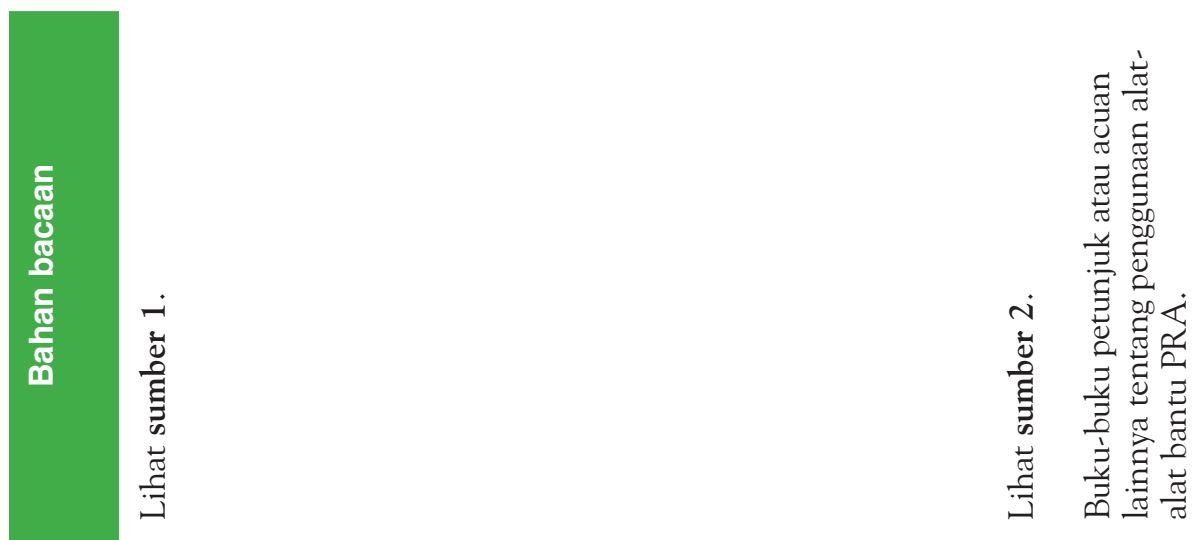

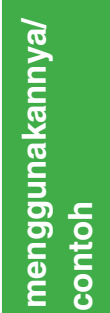
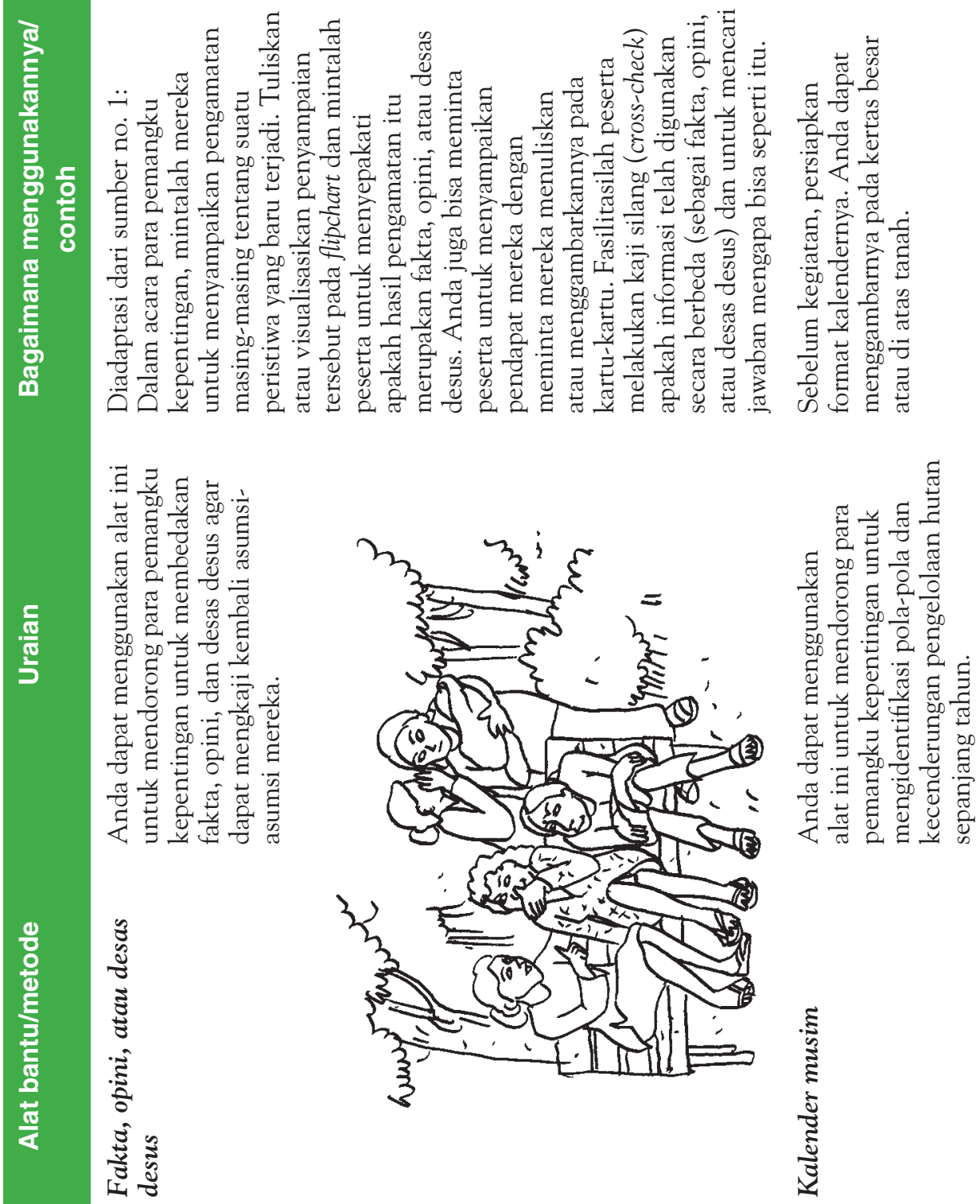


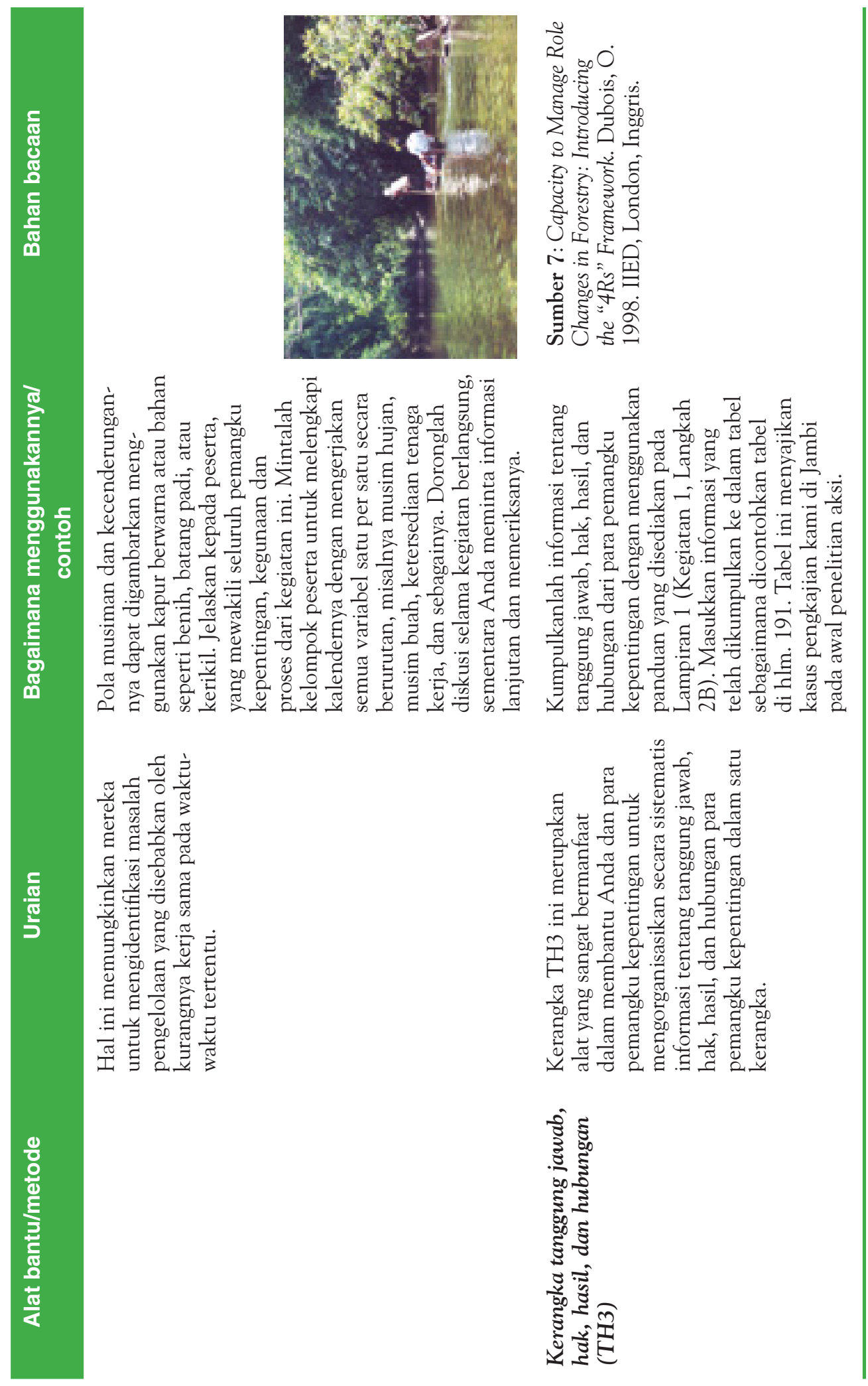




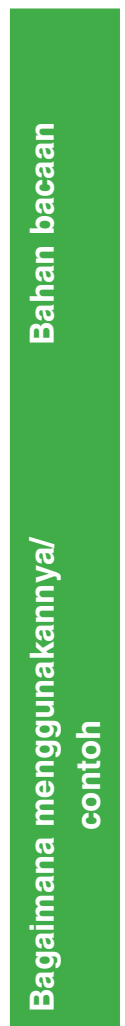

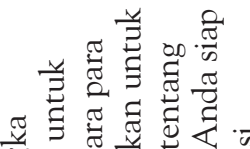

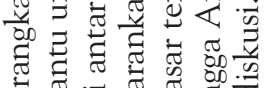

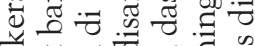
चี

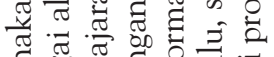

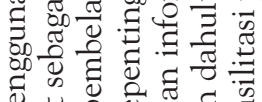

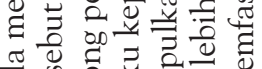

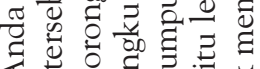

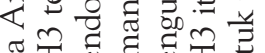

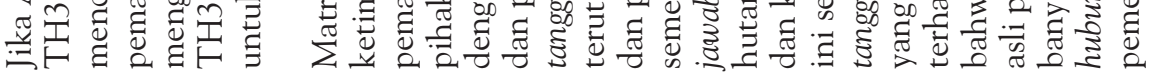

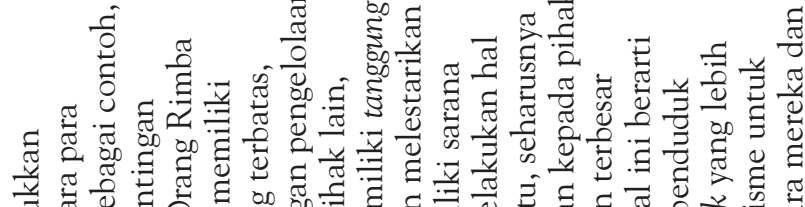

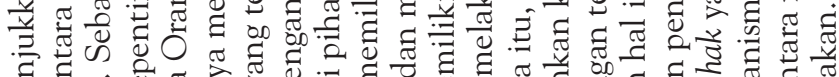

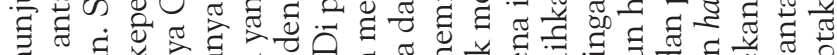

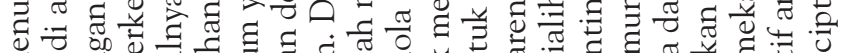

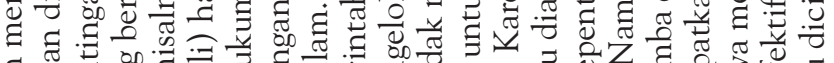

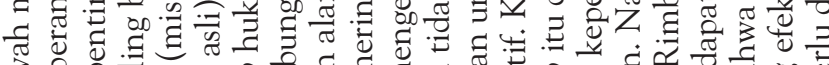

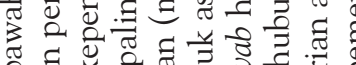

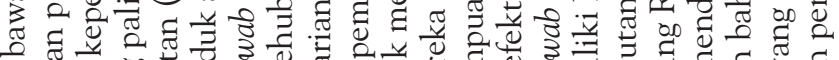
责范

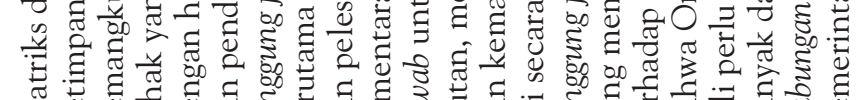
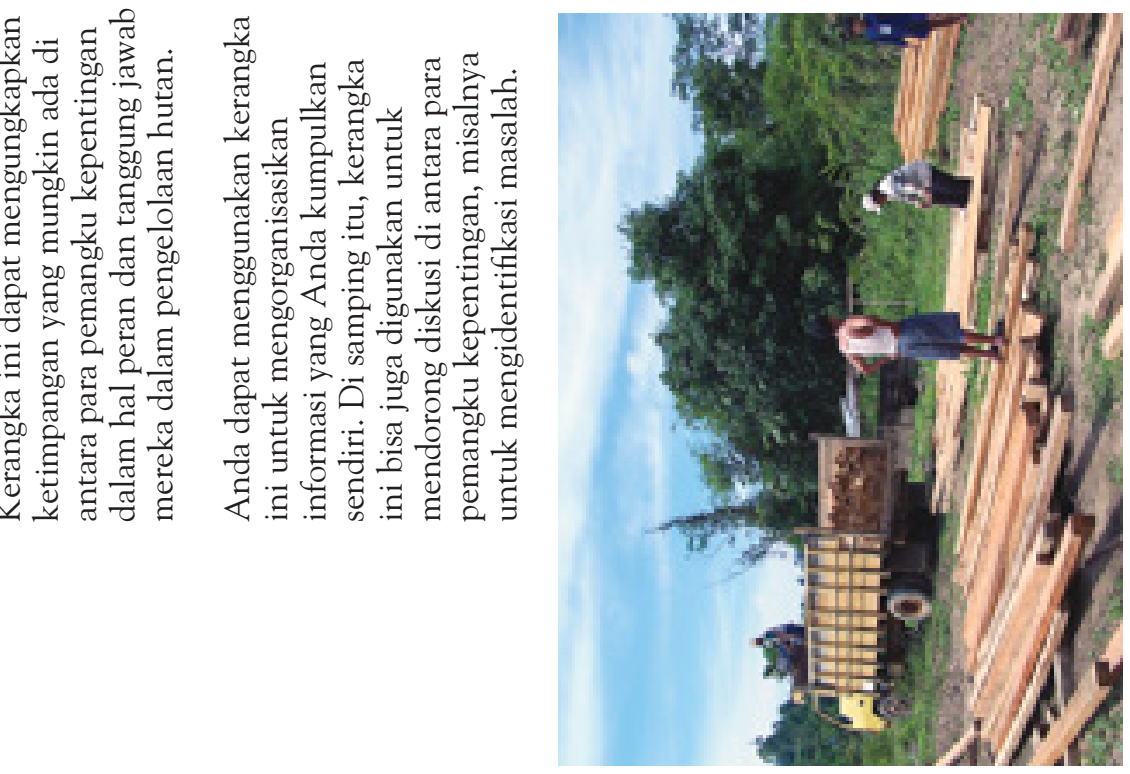


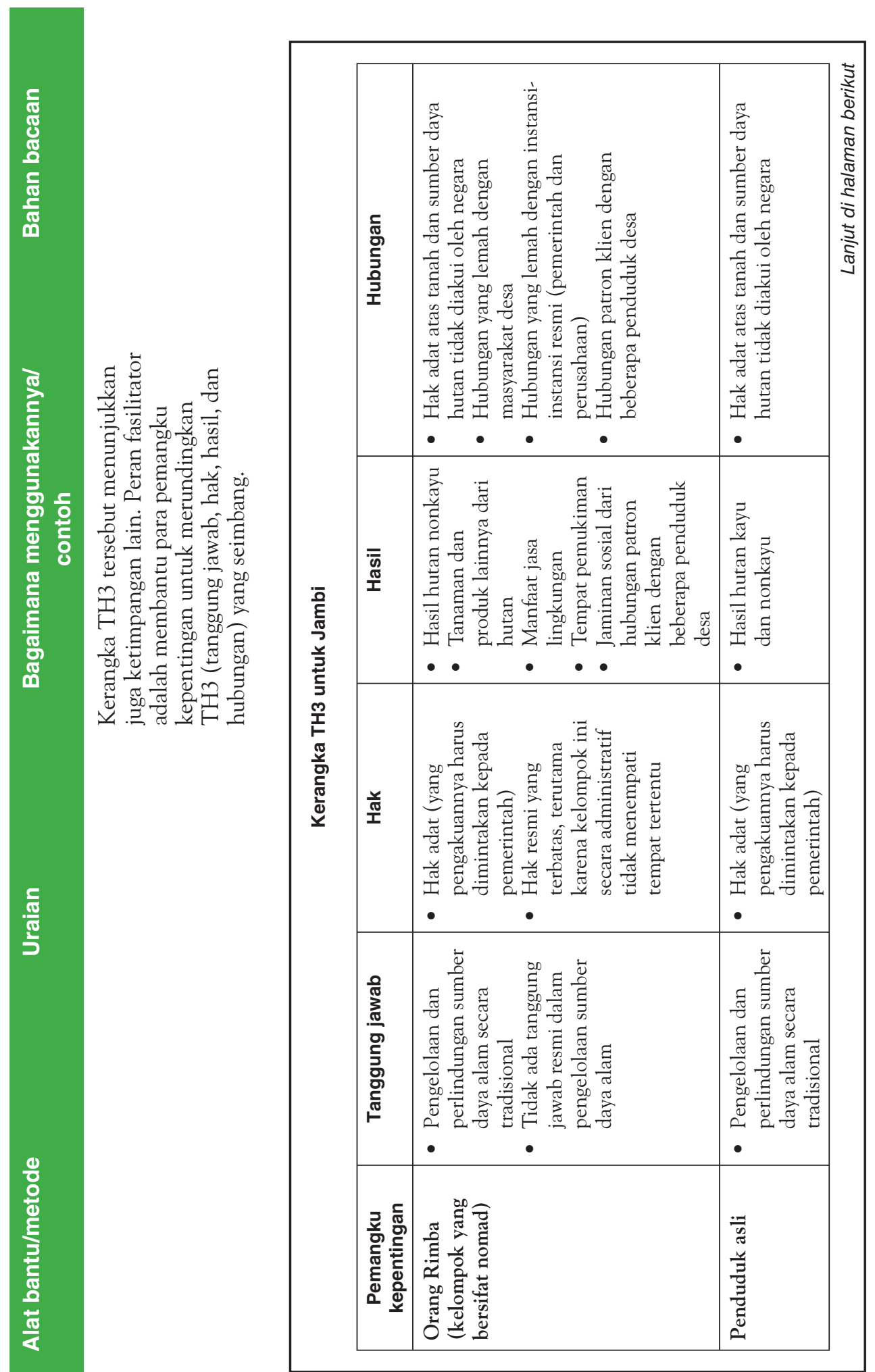




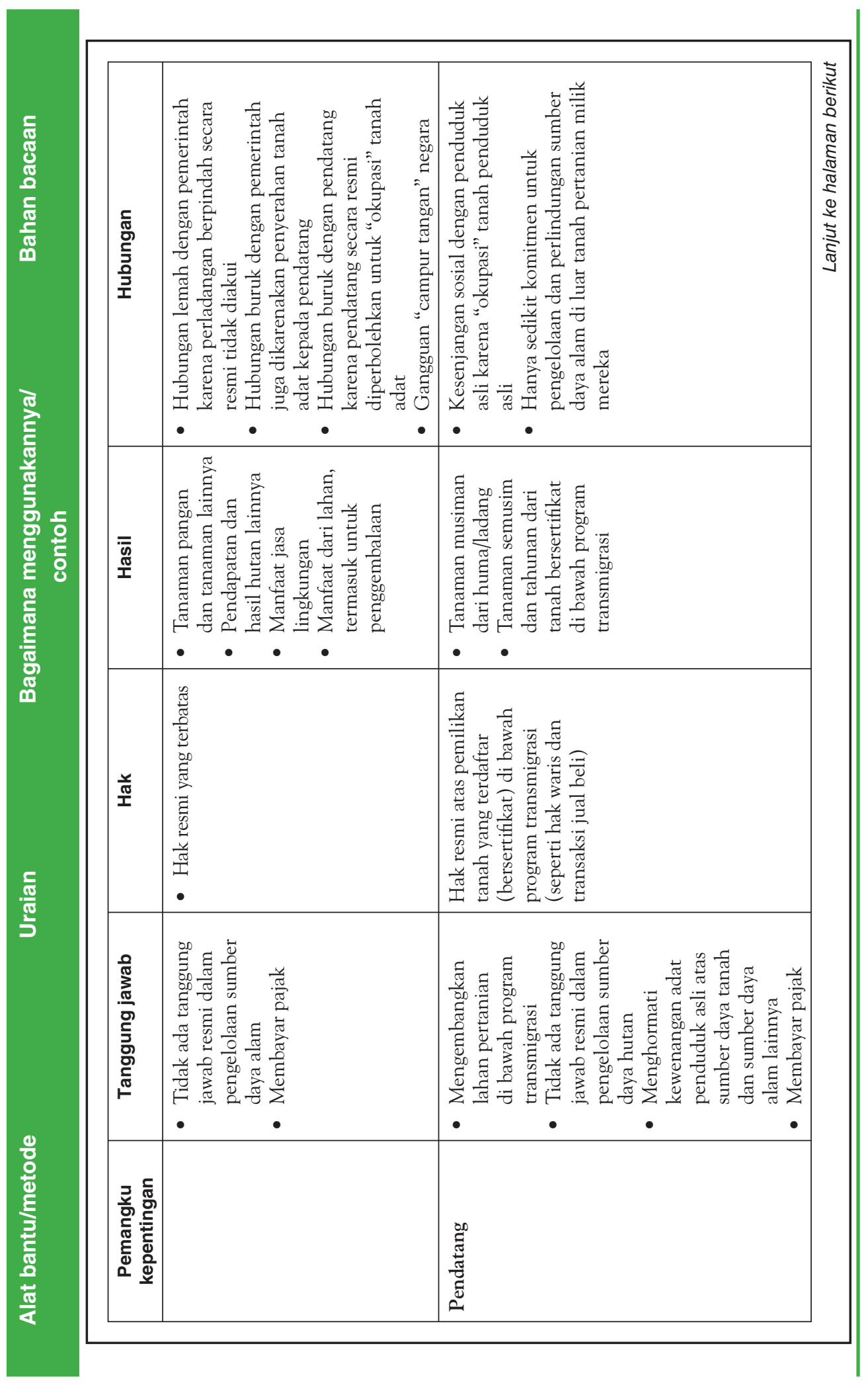




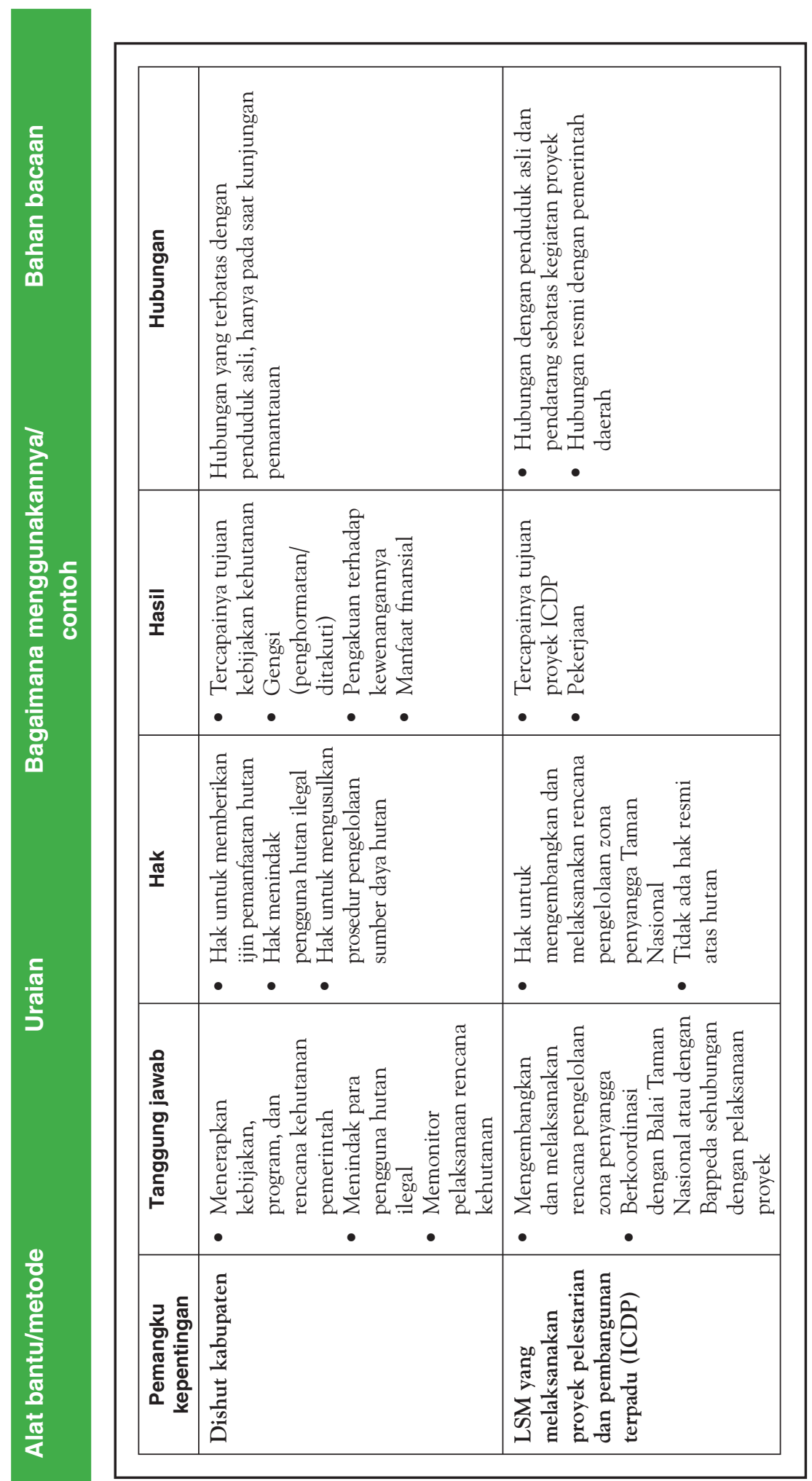




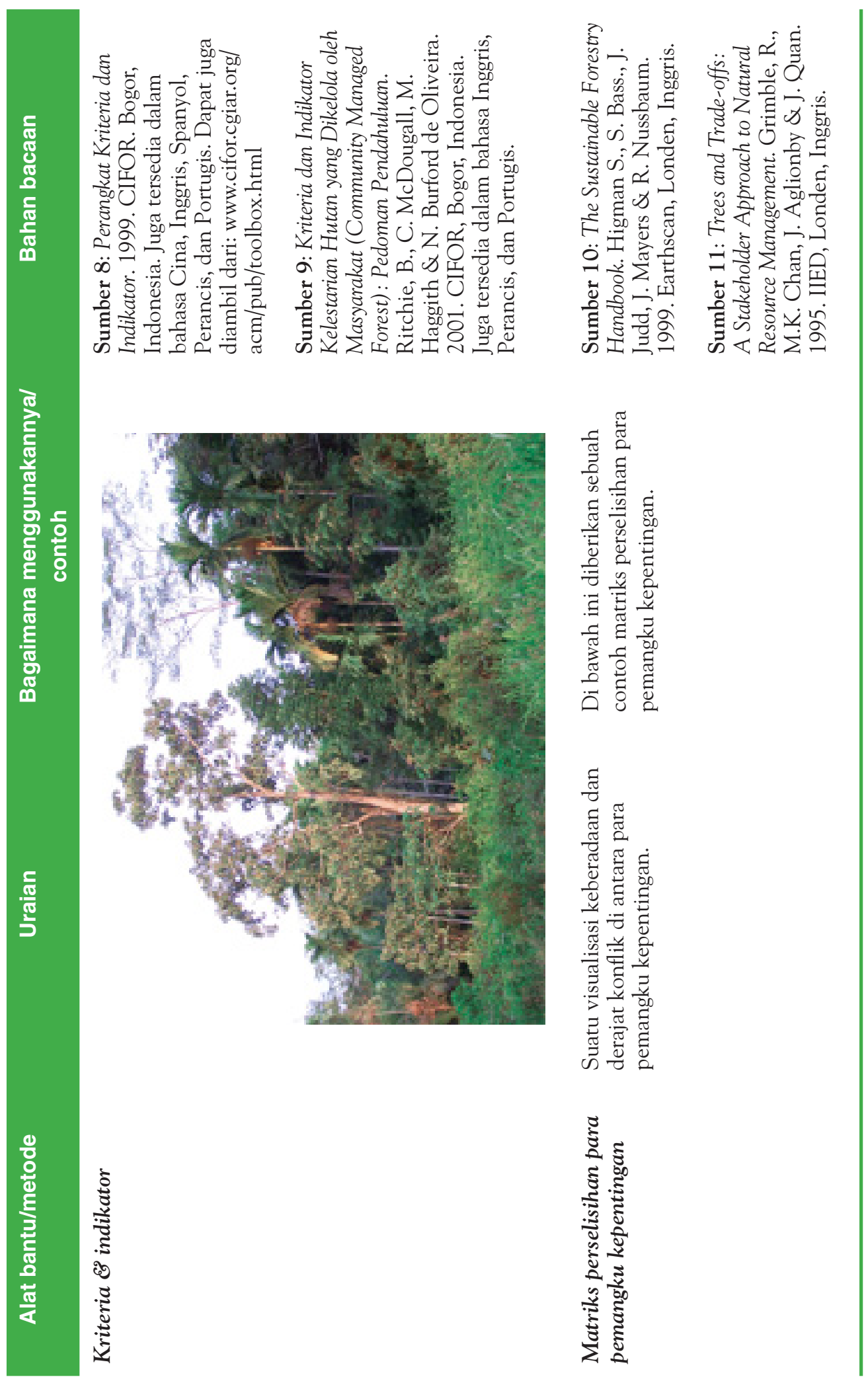




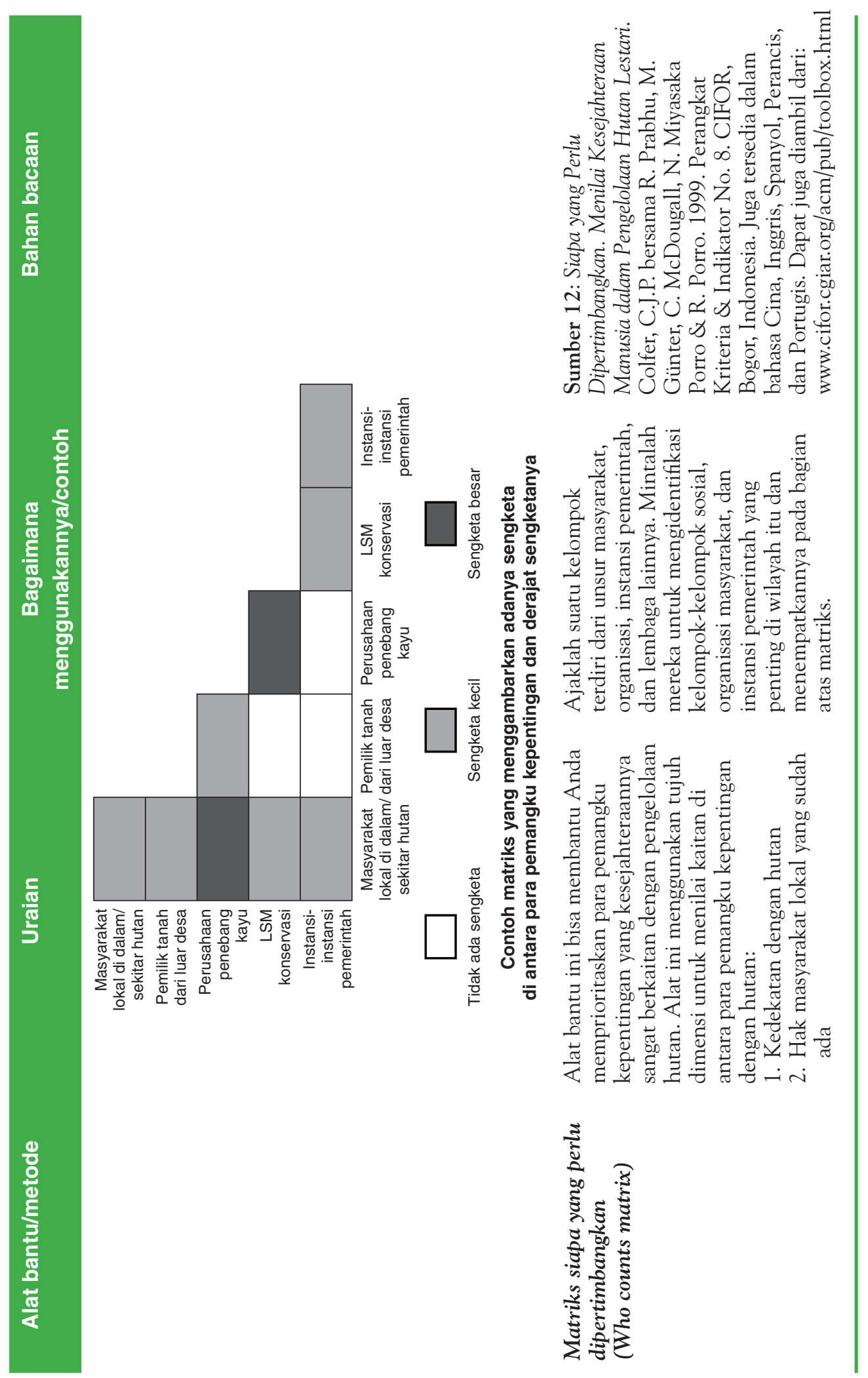



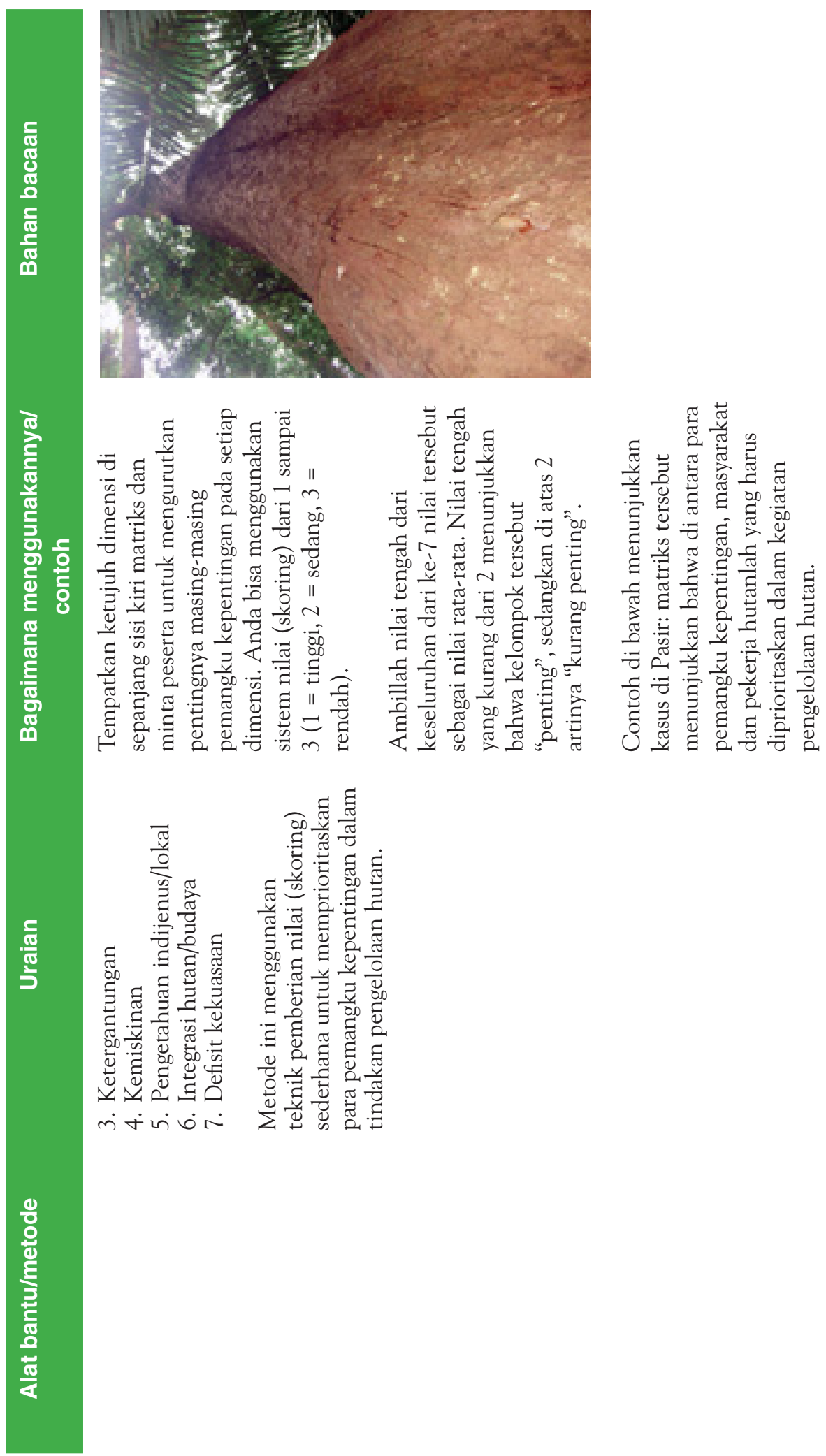


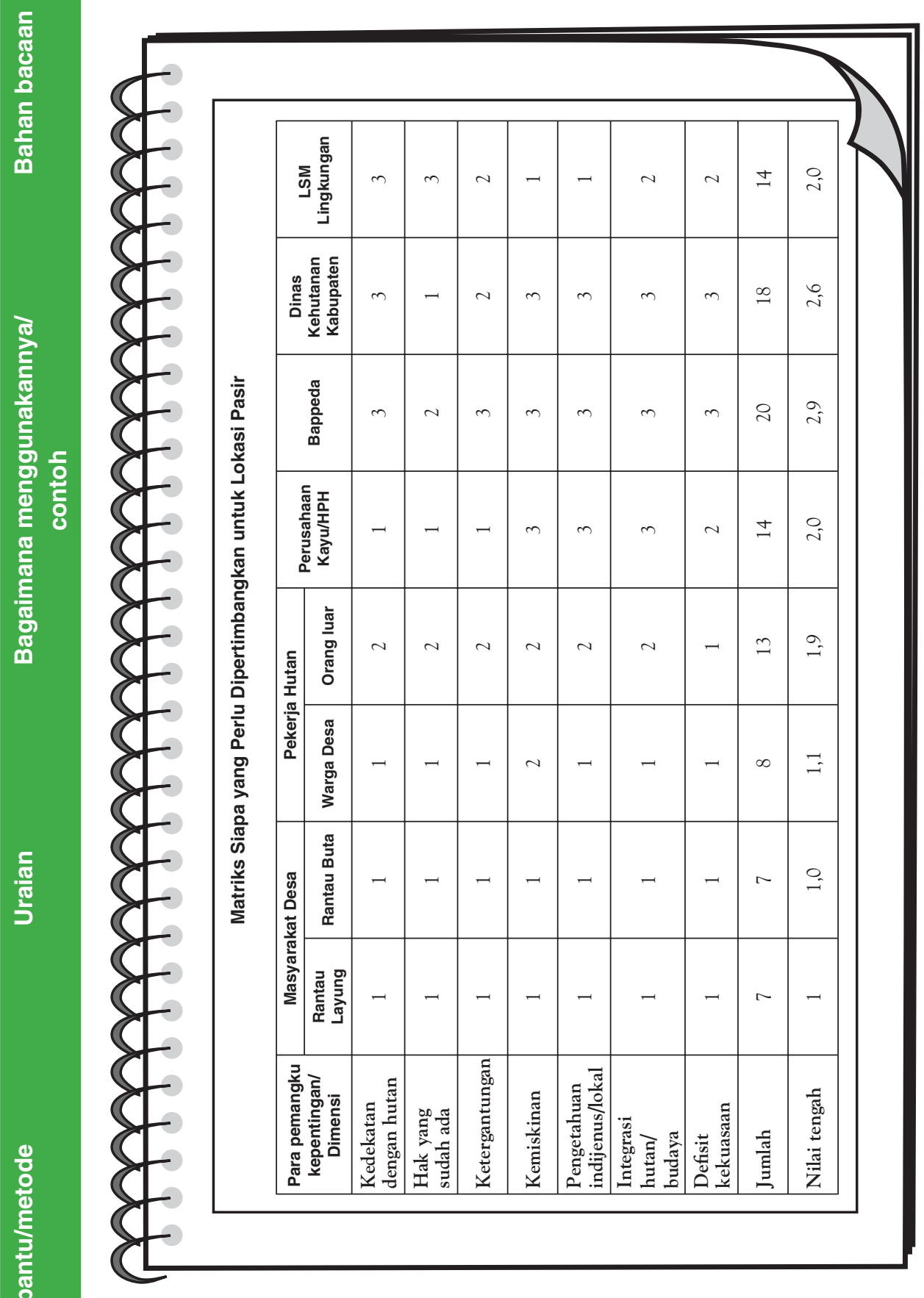




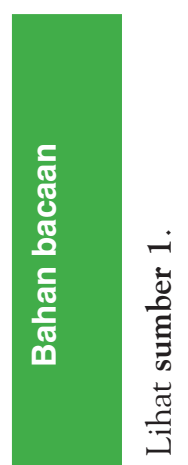

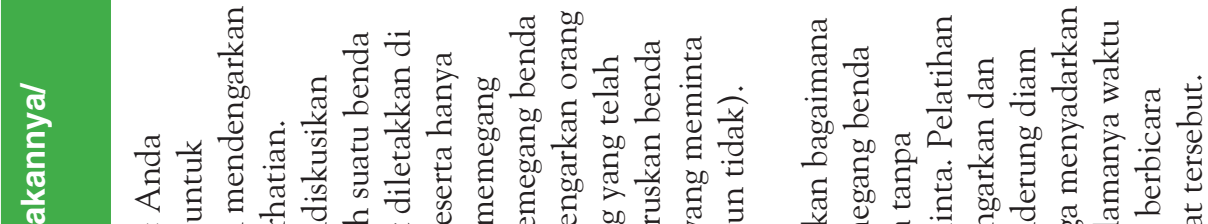

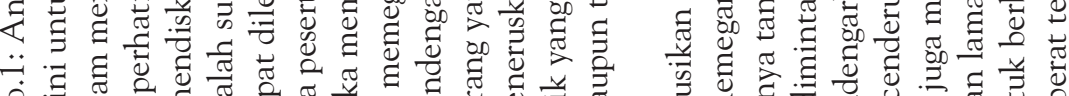

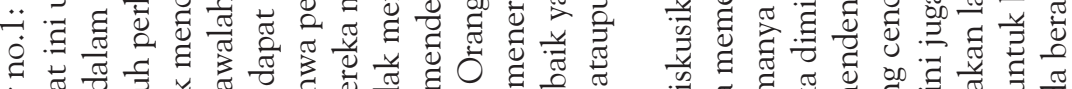

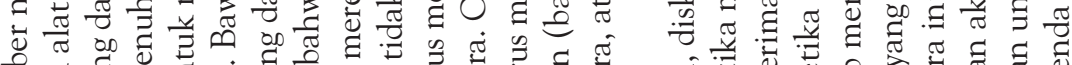

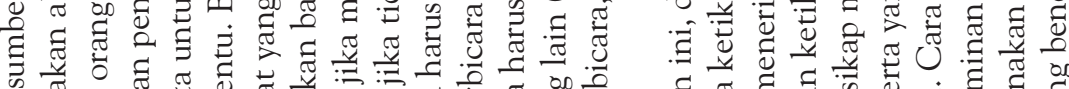

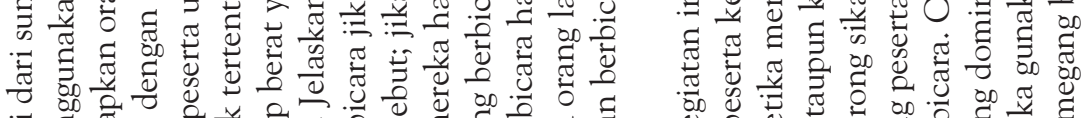

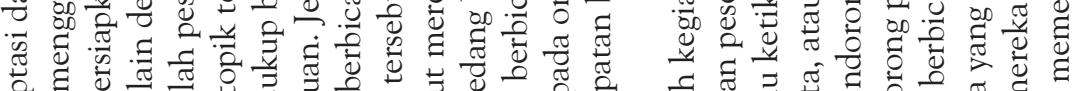

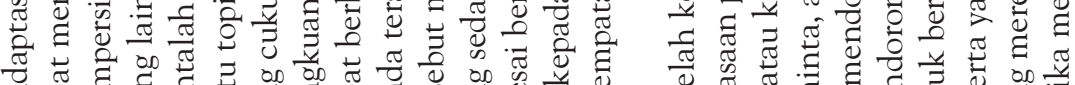

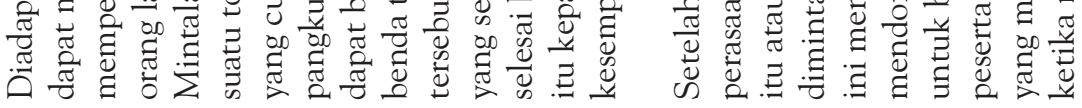
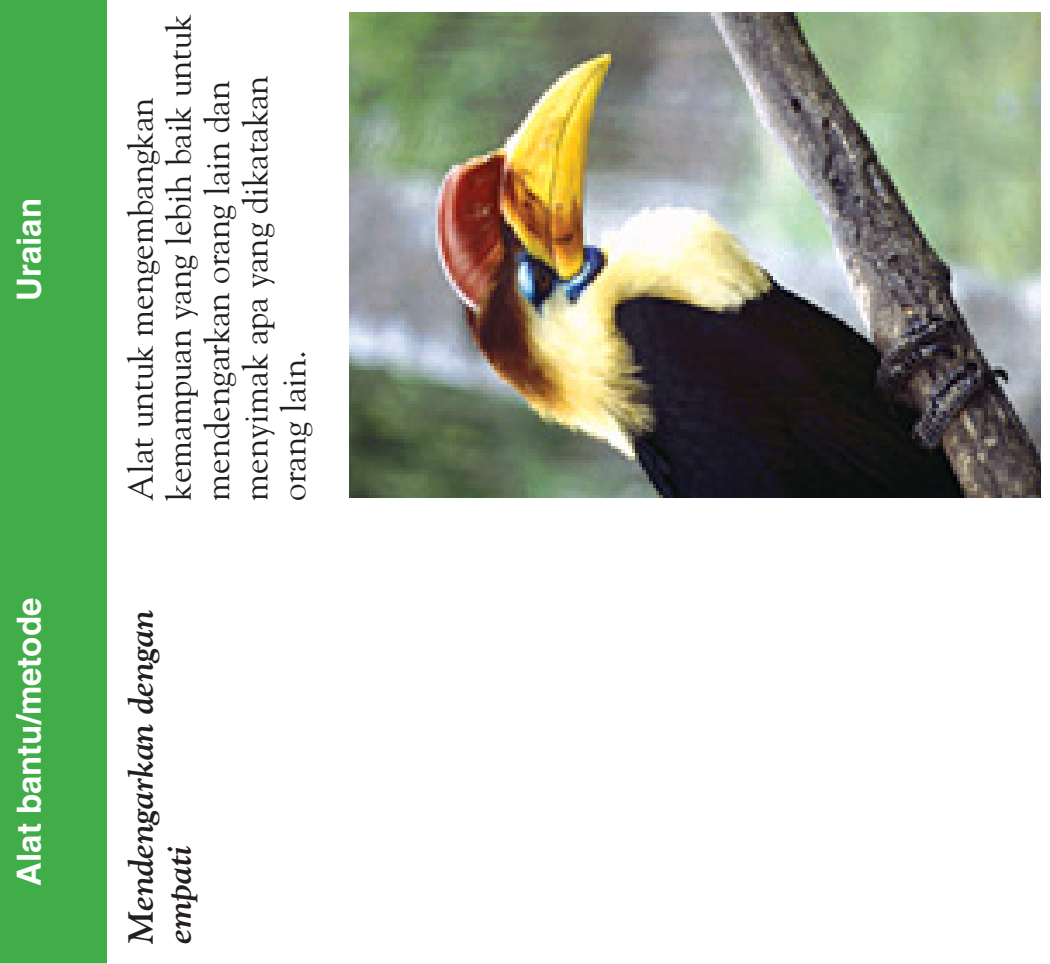


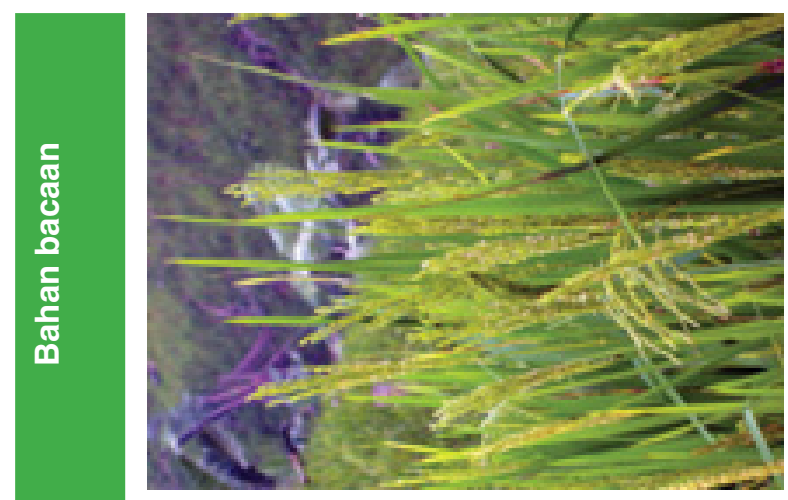

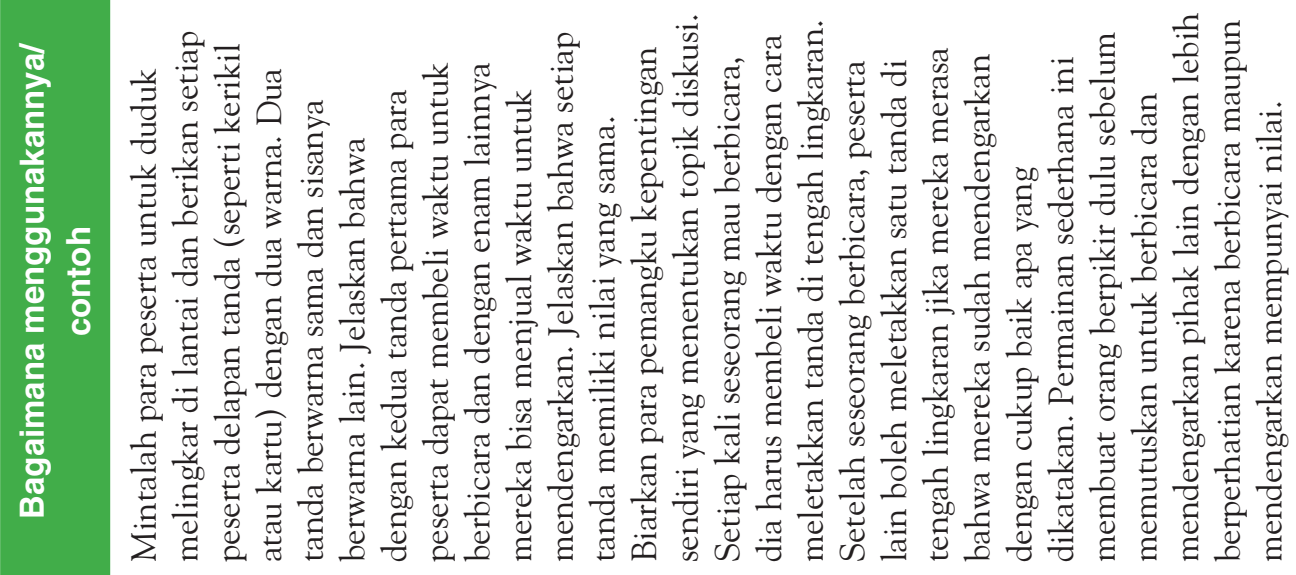
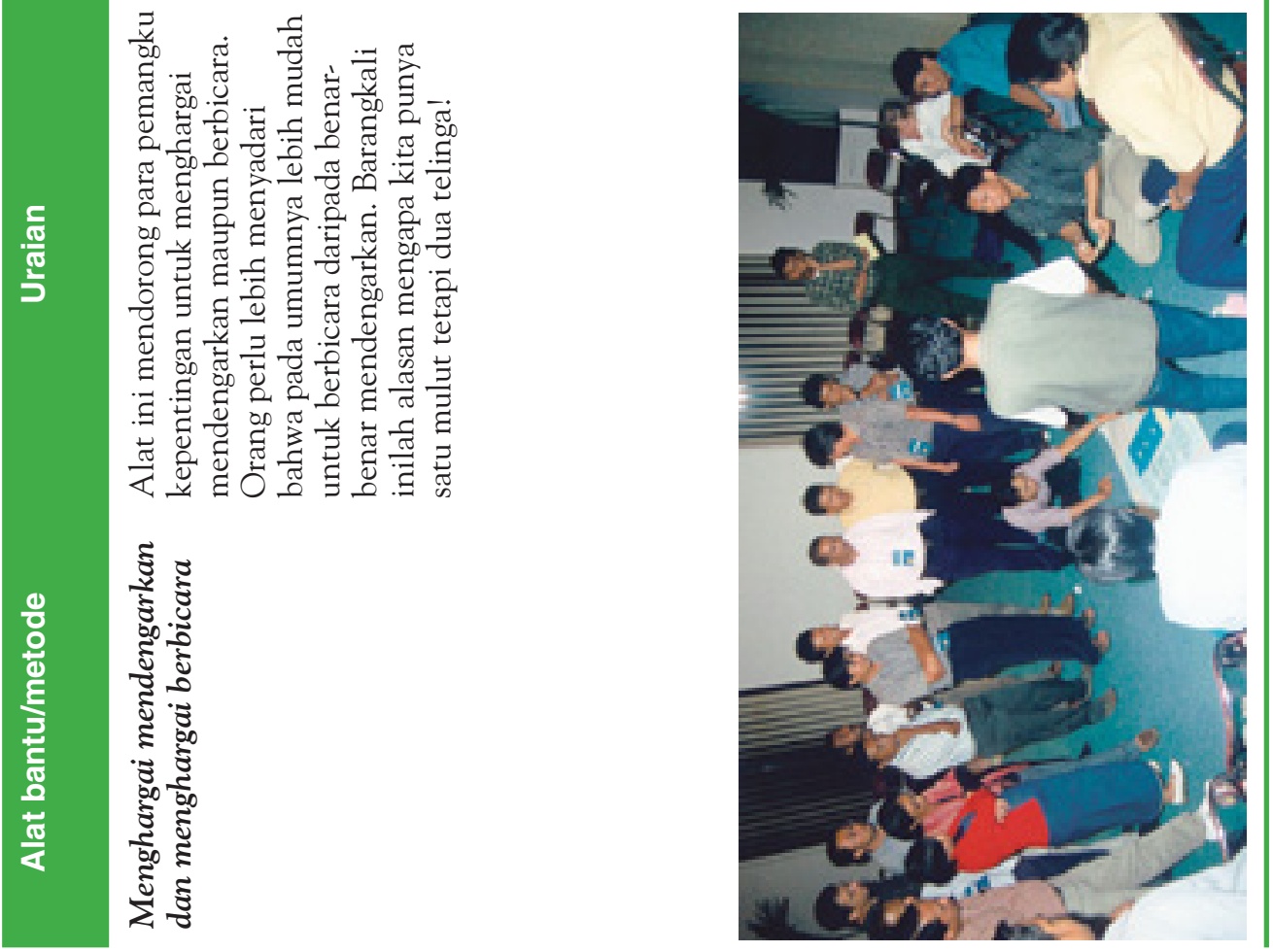

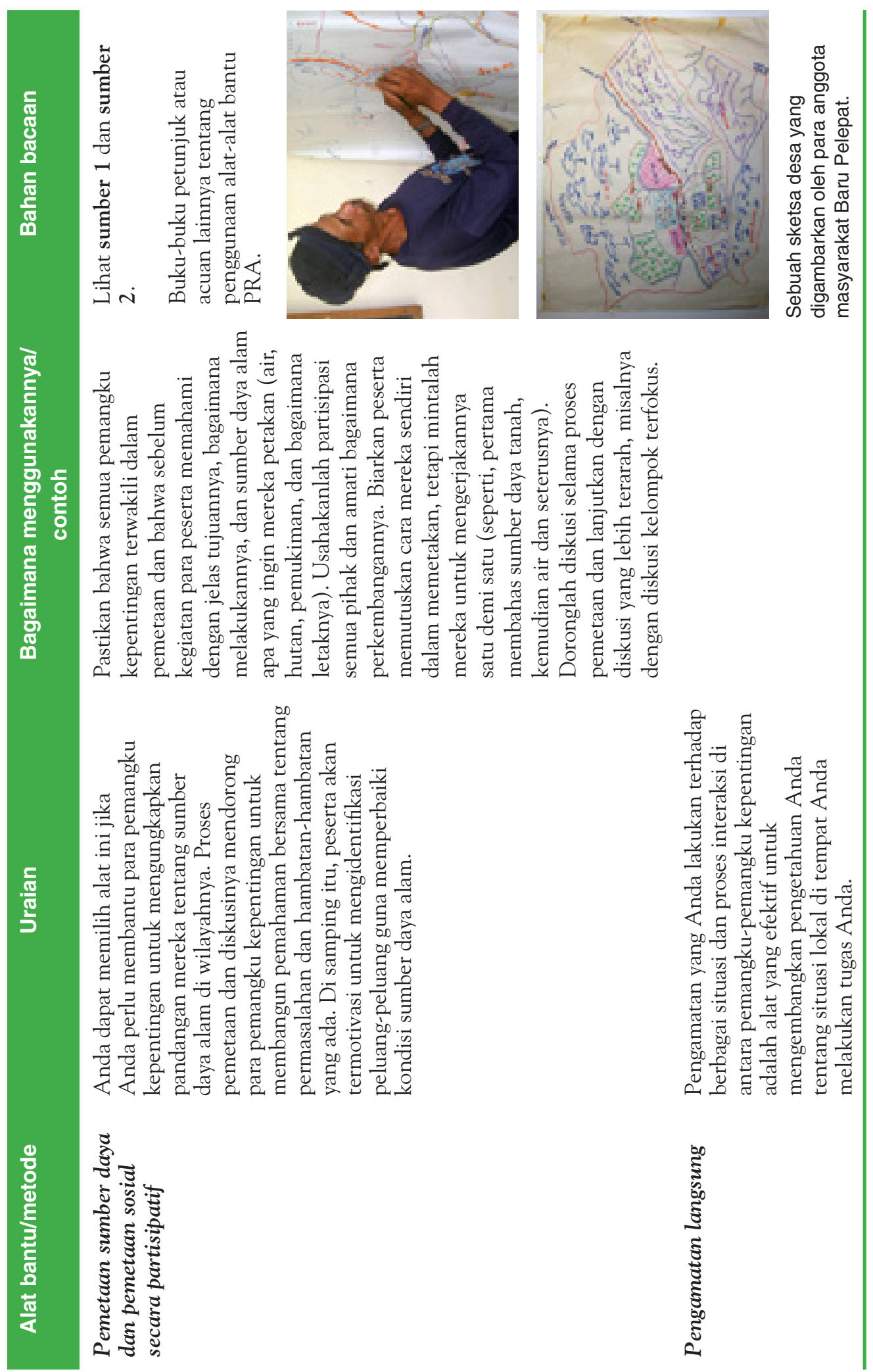


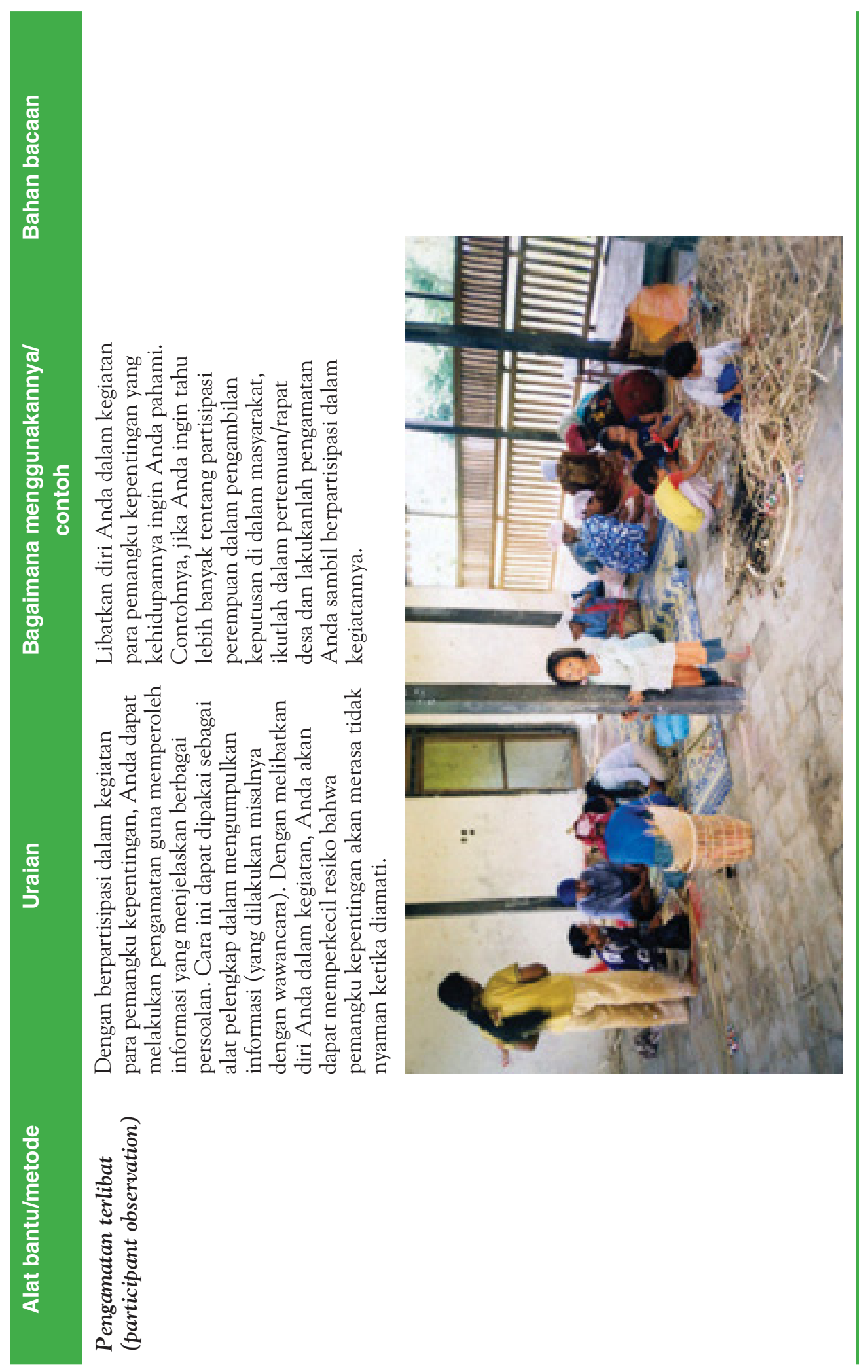




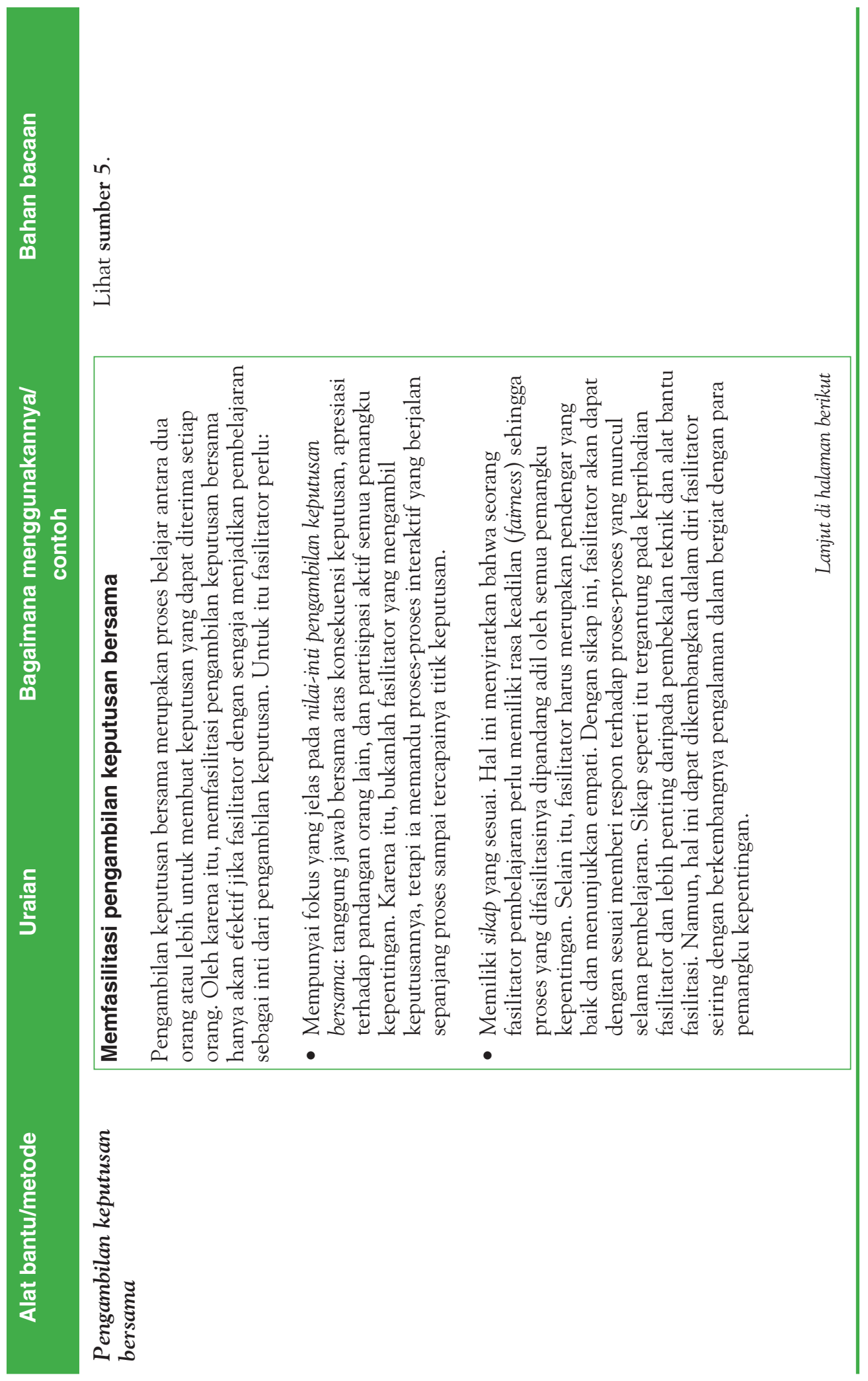




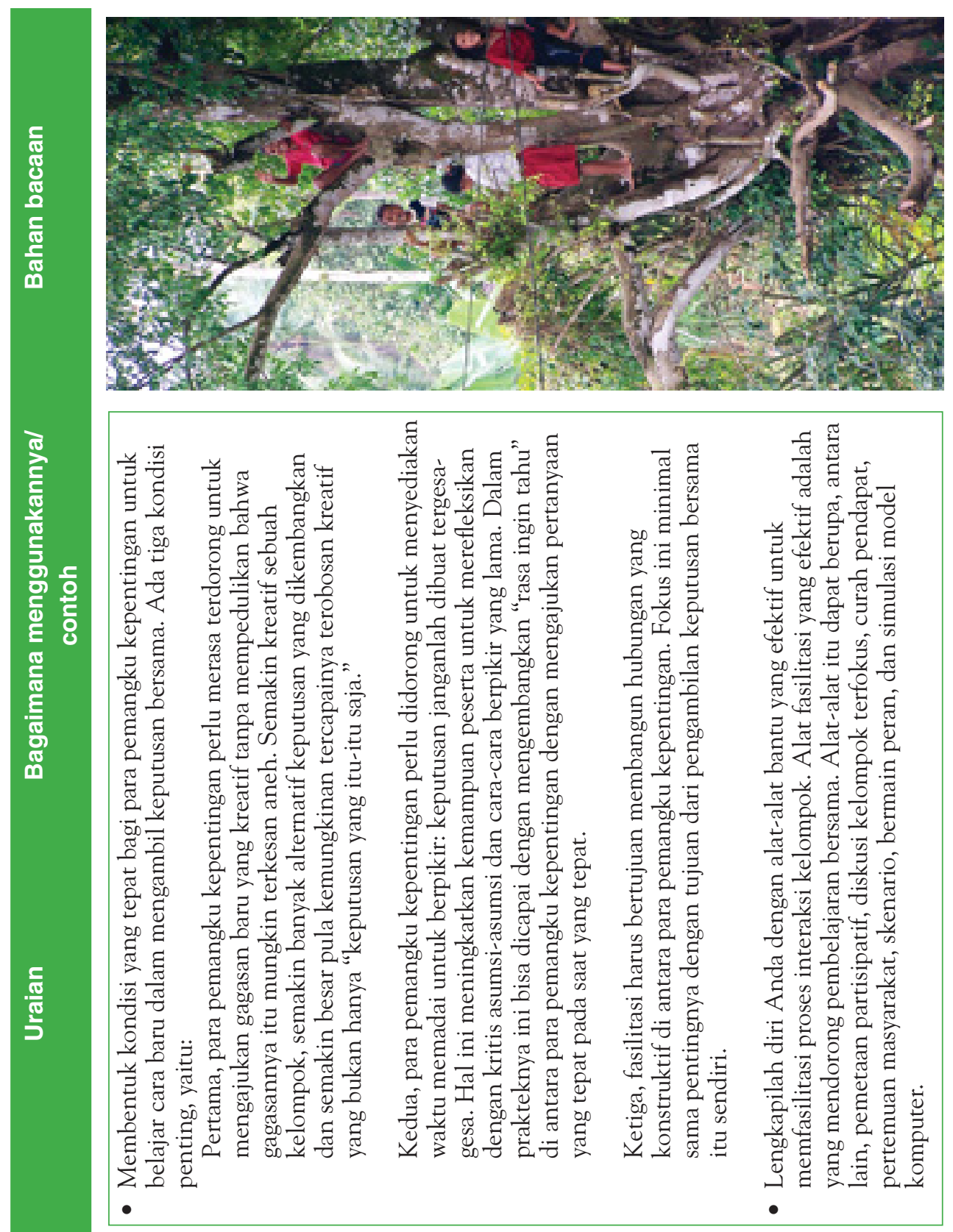




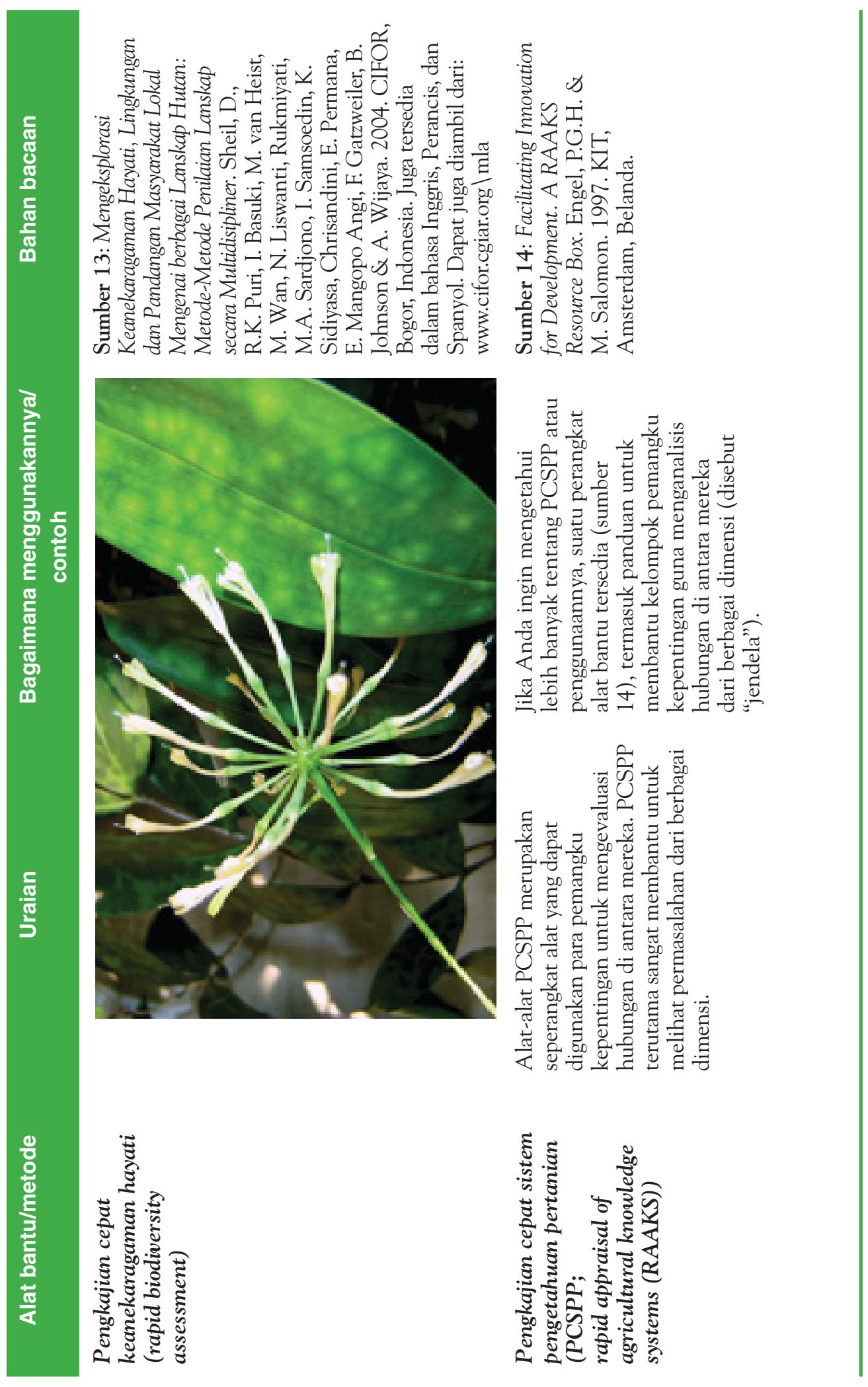




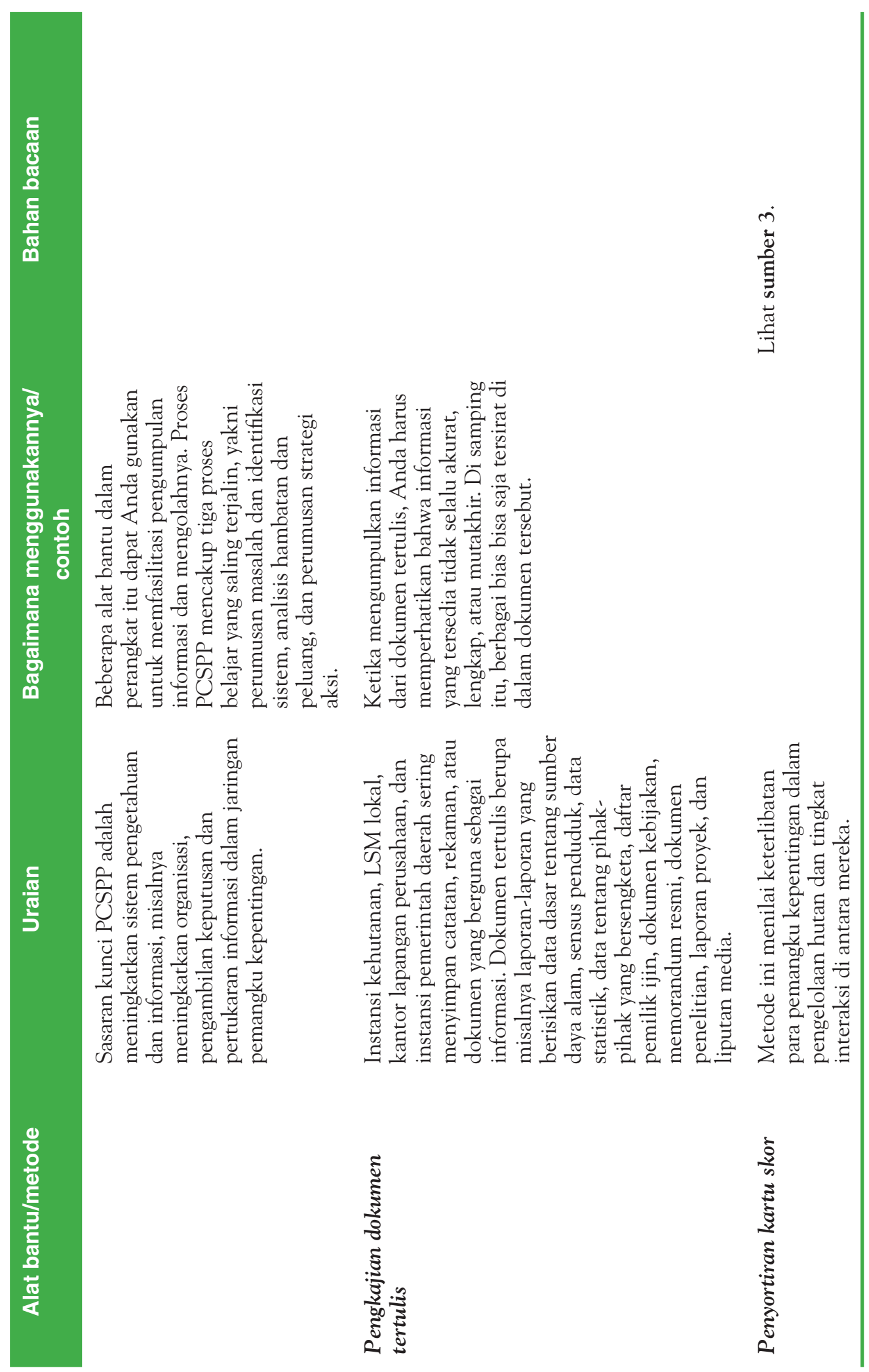




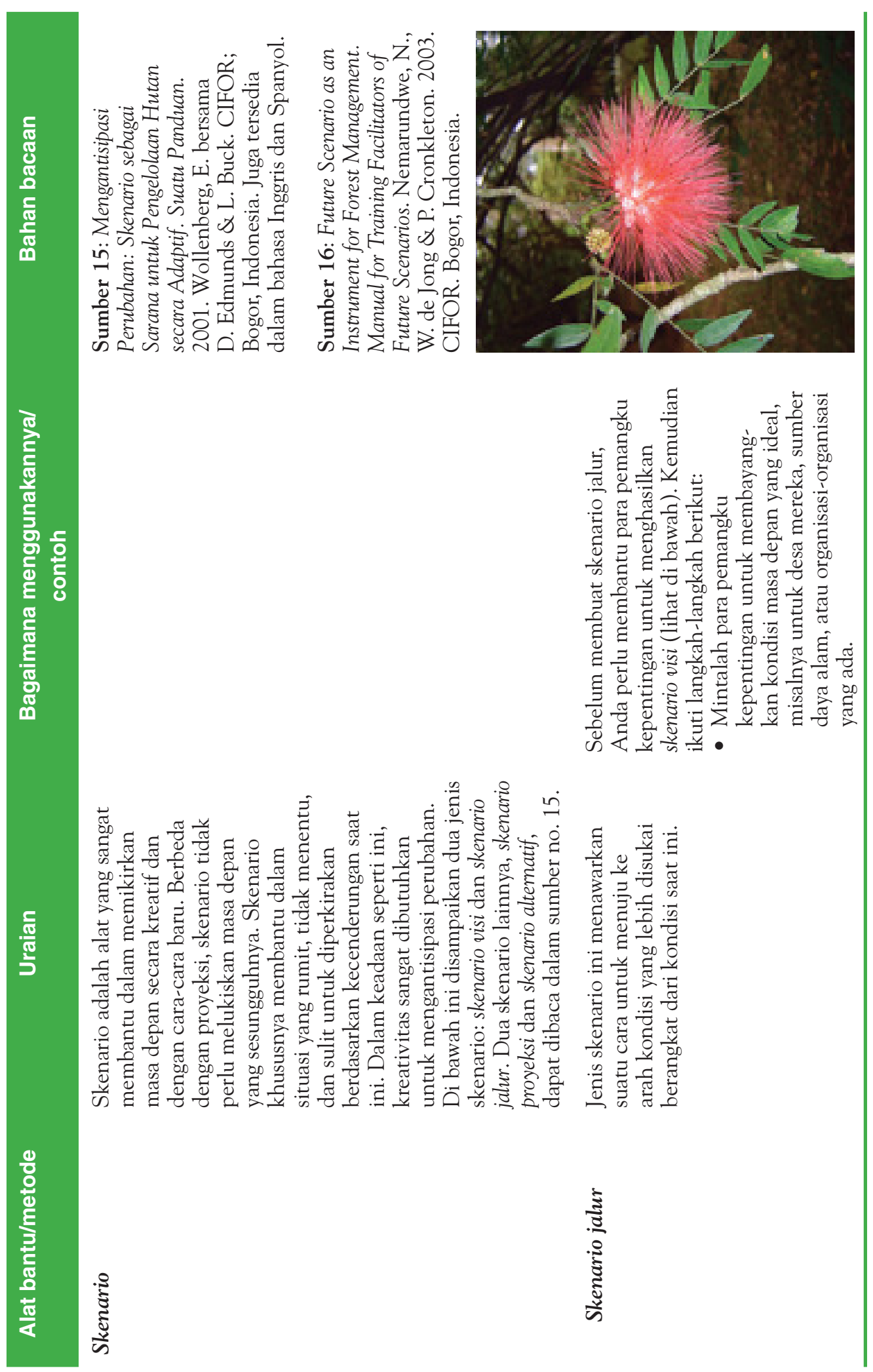




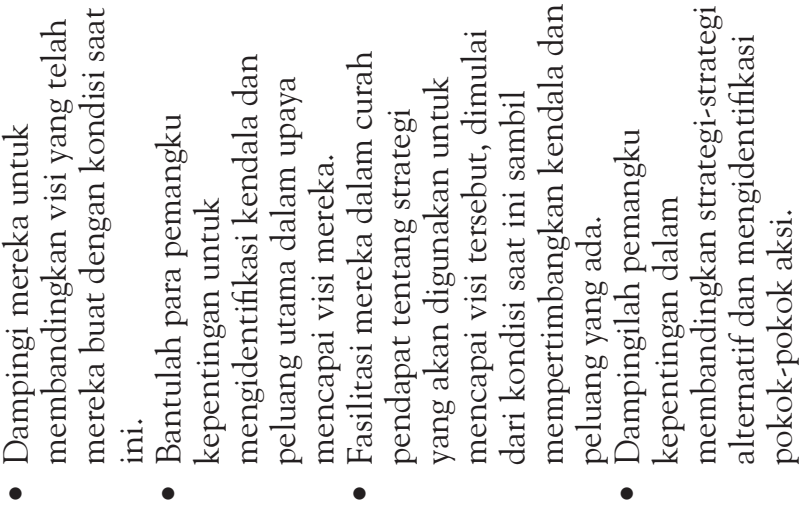

돈

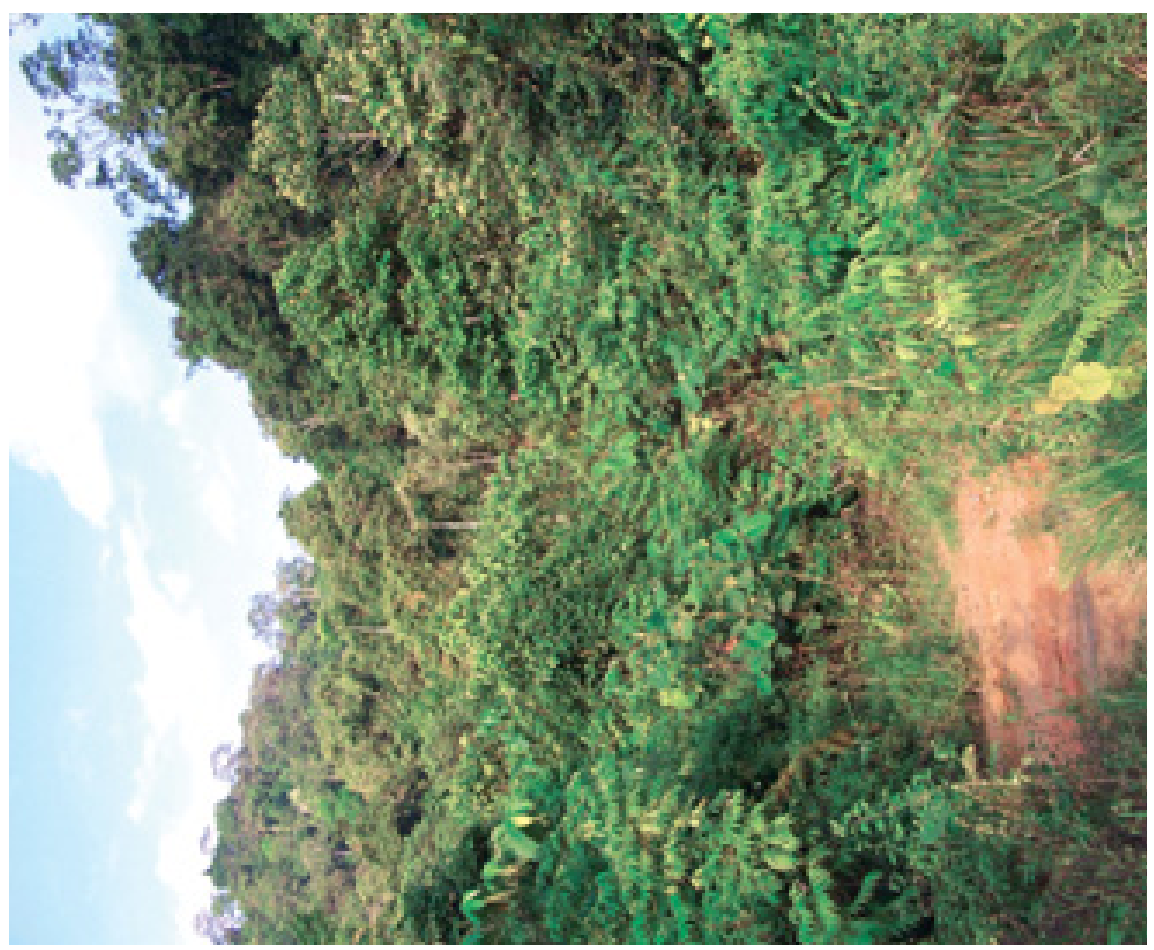



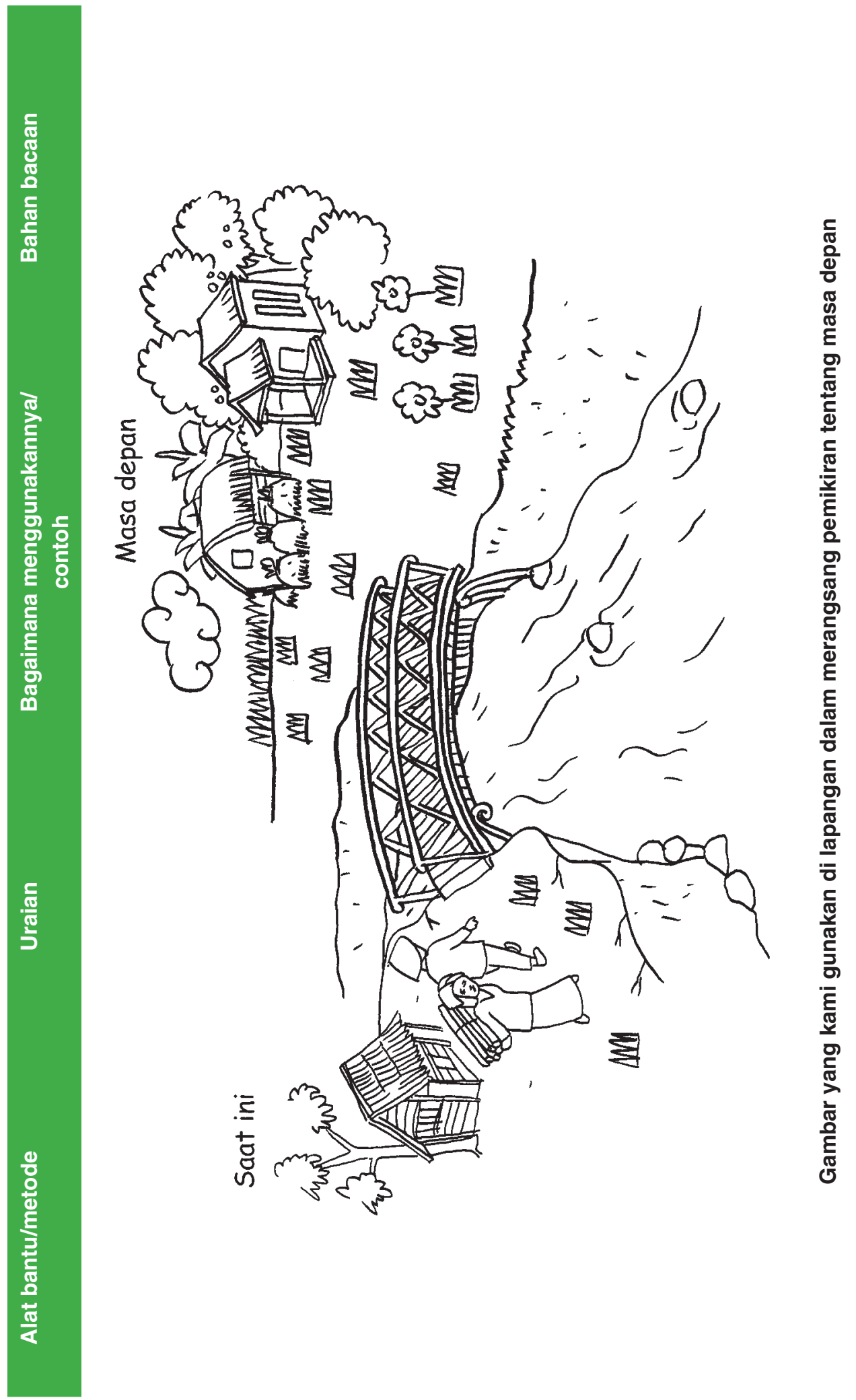


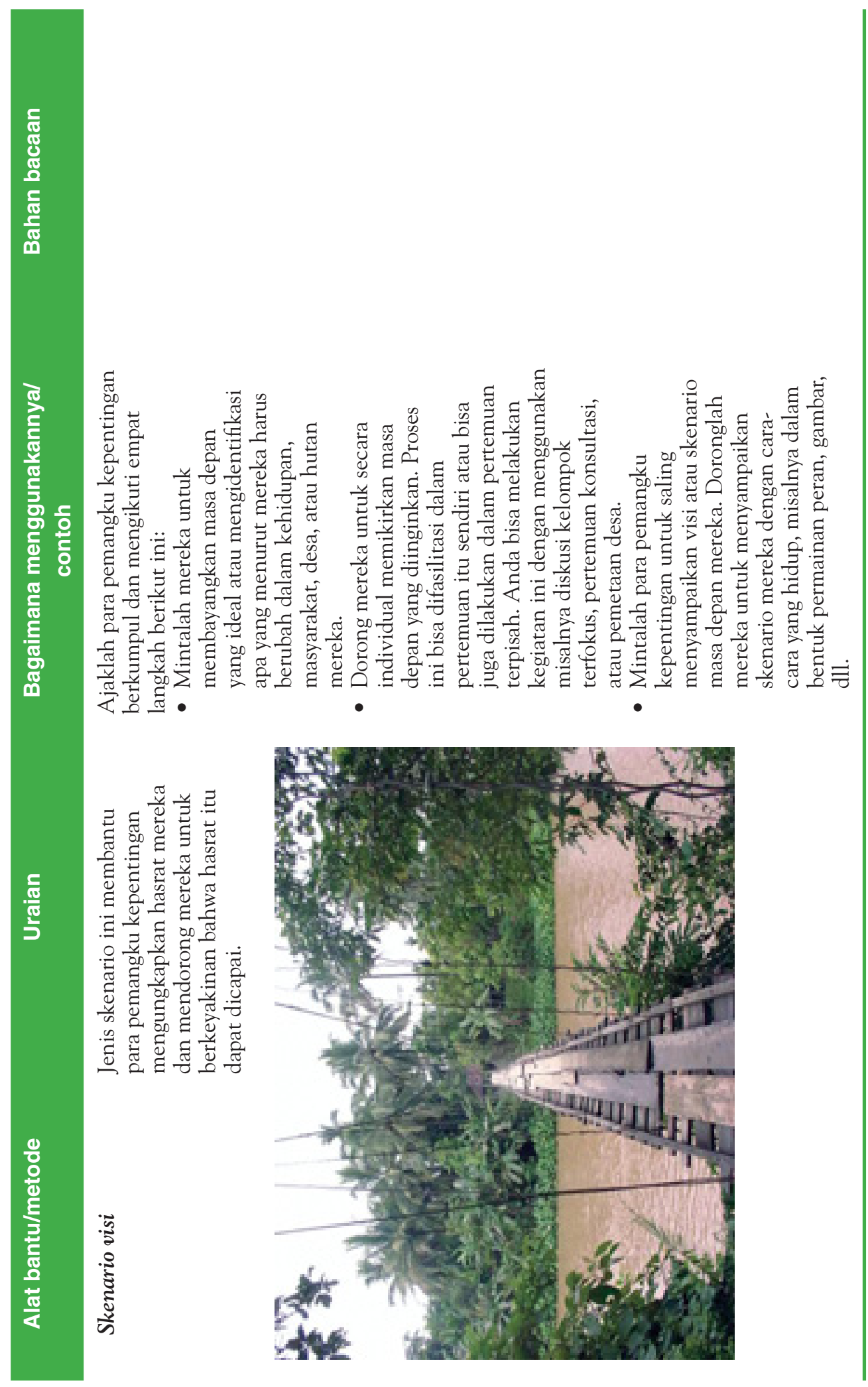




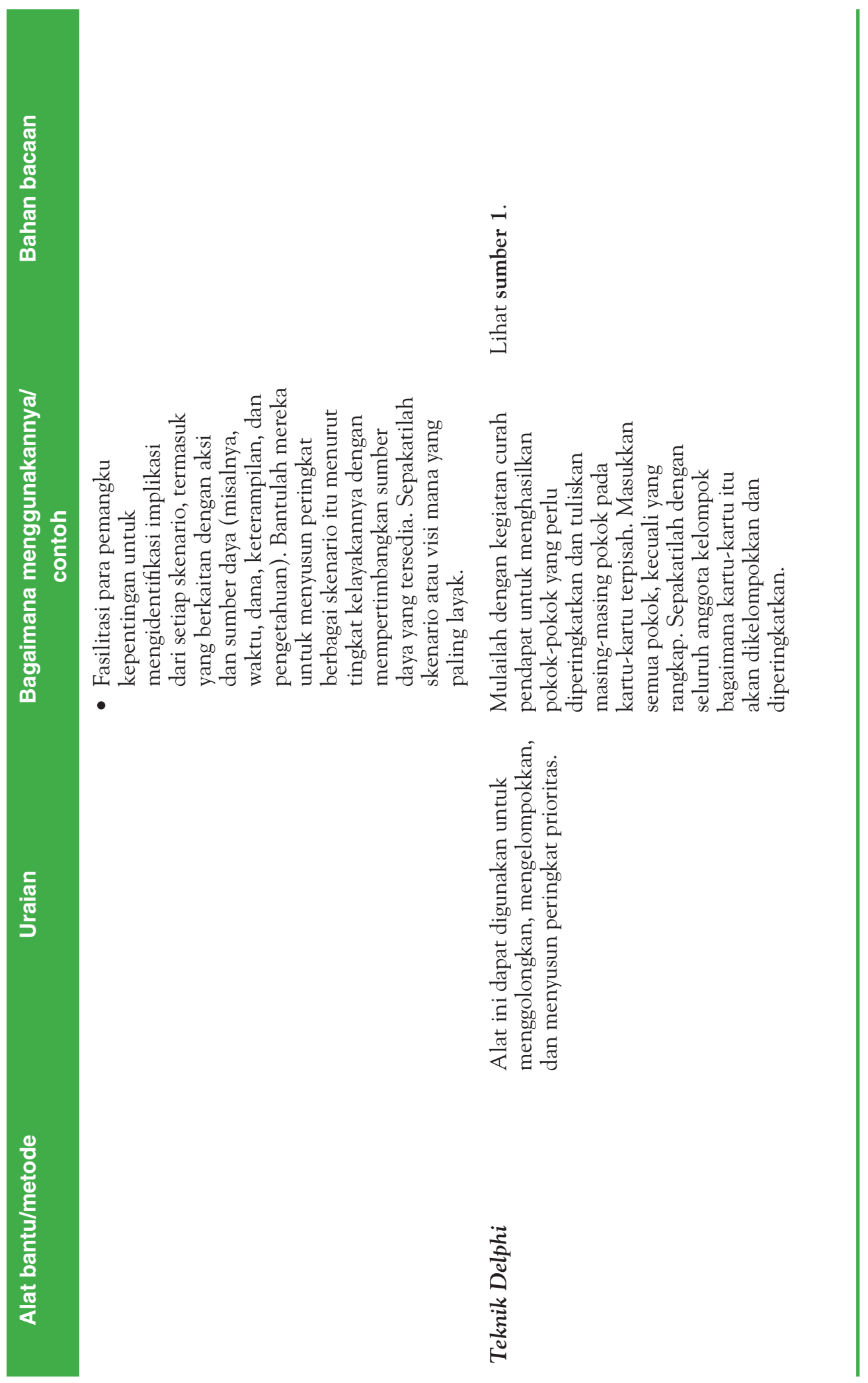




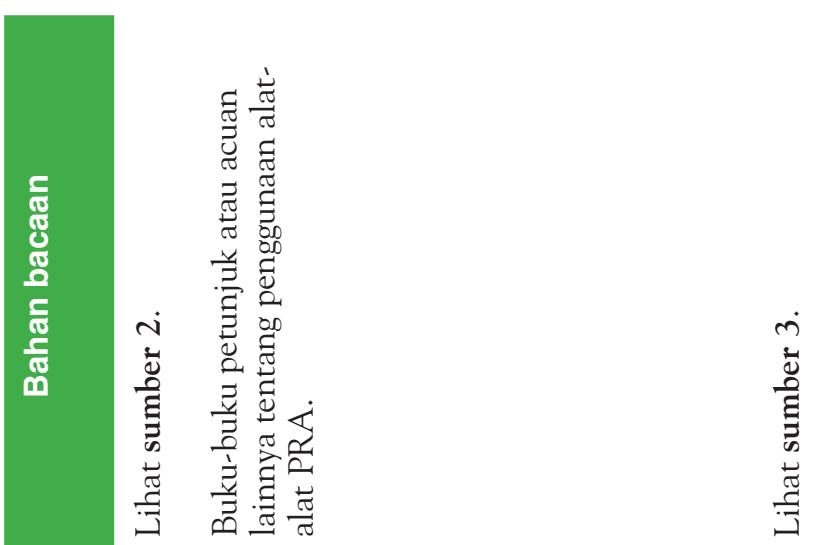

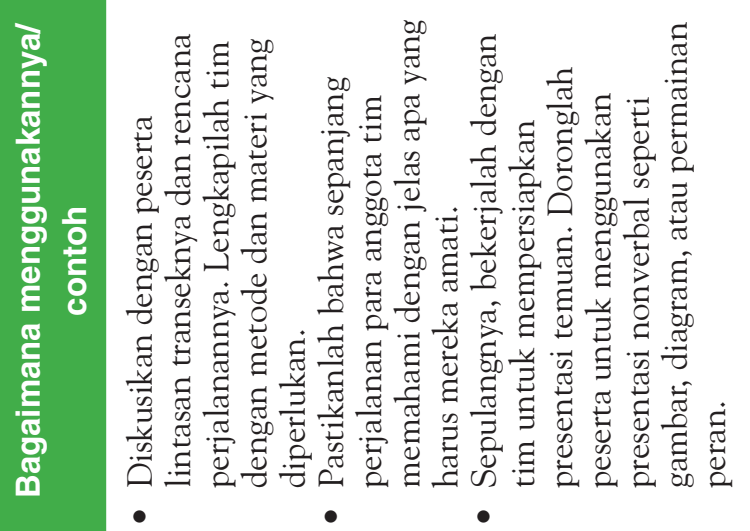
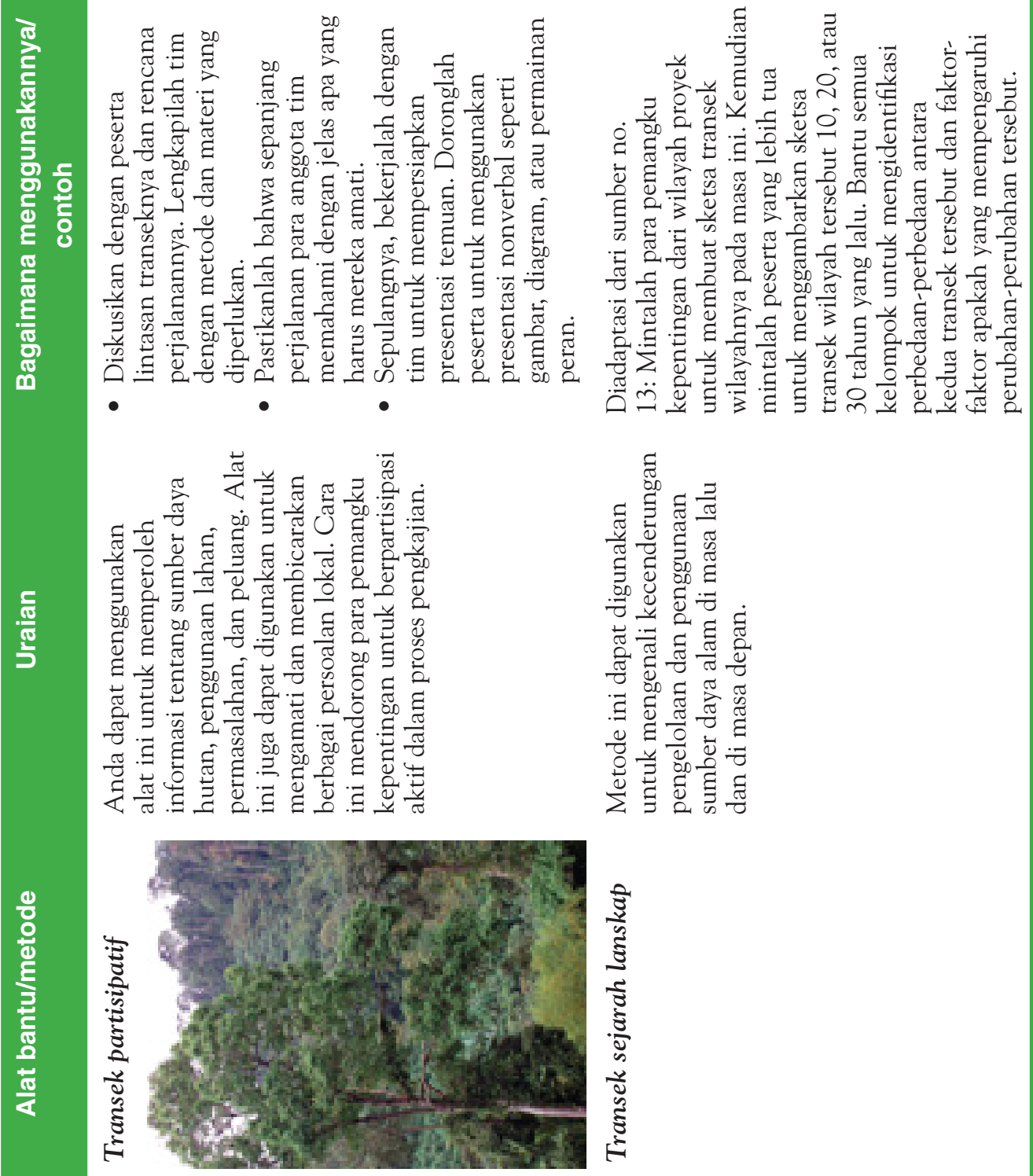


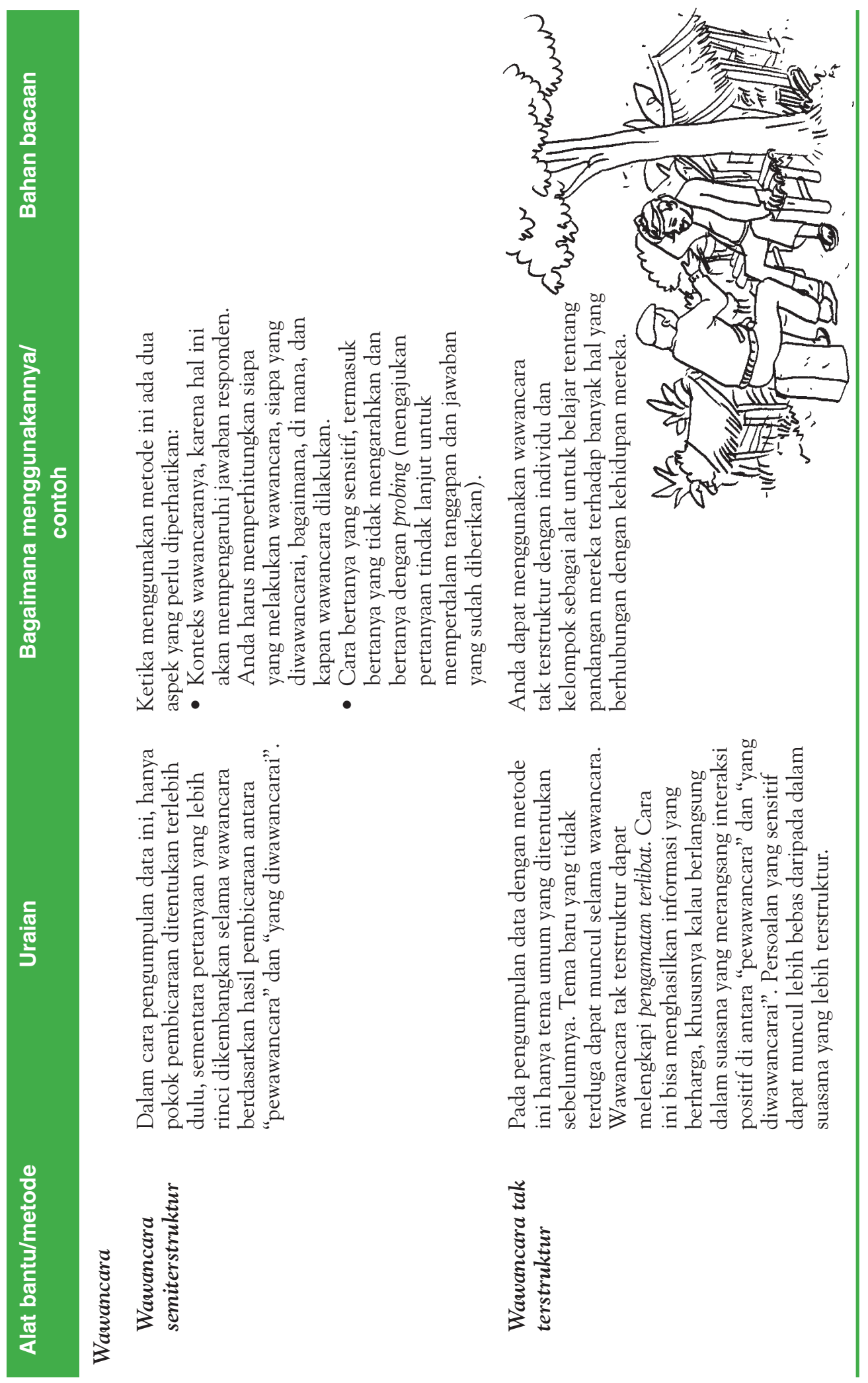




\section{CATATAN AKHIR}

1 Yayasan Gita Buana, Pusat Studi Hukum dan Kebijakan Otonomi Daerah, dan Yayasan Padi. Dua lembaga yang disebut pertama berlokasi di Jambi (Sumatera), sementara lembaga yang terakhir berlokasi di Samarinda (Kalimantan Timur).

2 Disesuaikan dari Hyperdictionary online. http://www.hyperdictionary.com/ search.aspx?define=adaptation dan http://www.hyperdictionary.com/search. aspx? define $=$ collaboration $($ May 17, 2006)

3 Disesuaikan dari McDougall, 2000.

4 Hartanto dkk., 2003.

5 Disesuaikan dari Buck dkk., 2001.

6 Diambil dari Braakman \& Edwards, 2002.

7 Disesuaikan dari Steins \& Edwards, 1999.

8 Kami mengartikan istilah "lembaga" dengan dua cara. Pertama, lembaga (institution) adalah suatu struktur atau mekanisme sosial yang bertujuan untuk mendukung kehidupan kolektif sekelompok orang, seperti misalnya dalam "lembaga adat", "lembaga pendidikan", dan "lembaga keagamaan". Tujuan suatu lembaga dicapai melalui pengaturan (penerapan normanorma atau aturan-aturan) terhadap perilaku para anggotanya. Kedua, kata lembaga (institute) dapat juga diartikan sebagaimana lebih umum digunakan di Indonesia, yakni sebagai organisasi atau instansi yang berbadan hukum, seperti misalnya dalam "lembaga pemerintah desa", "lembaga donor", dan "lembaga pemuda".

9 Kami menggunakan istilah "perhutanan sosial" sebagai konsep payung untuk menjelaskan berbagai bentuk pelibatan masyarakat atau kelompok lokal dalam kebijakan dan program pengelolaan hutan.

10 Lihat, sebagai contoh, Sarin, 1998.

11 Undang-Undang No. 5 Tahun 1979 tentang Tata Pemerintahan Desa, yang telah digantikan oleh undang-undang desentralisasi pada tanggal 1 Januari 2001.

12 Disesuaikan dari gagasan "platform" sebagaimana dirumuskan oleh Röling \& Jiggins, 1998.

13 Lihat, misalnya, Groot dkk., 2002.

14 Lihat Kolb, 1984.

15 Lihat, sebagai contoh, Bawden, 1991.

16 Disesuaikan dari Kusumanto, akan diterbitkan. 
17 Menurut Dubois, 1998.

18 Lihat Buck dkk. 2001 dan 2005.

19 Lihat Maarleveld \& Dangbégnon, 1999.

20 Lihat, sebagai contoh, Wollenberg dkk., 2000.

21 Lihat Carney (penyunting), 1998.

22 Pengertian "insentif" di sini bukan hanya mencakup imbalan finansial, tetapi juga insentif dalam bentuk nonfinansial, seperti hak kelola atas hutan, kesempatan pelatihan dan pendidikan, promosi jenjang karier, dsb. 


\section{DAFTAR PUSTAKA}

Bawden. R.J. 1991. Systems Thinking and Practice in Agriculture. Dalam: Journal of Dairy Science, 74.

Braakman, L. \& K. Edwards. 2002. The Art of Building Facilitation Capacities. A Training Manual. RECOFTC, Bangkok, Thailand.

Buck, L., E. Wollenberg \& D. Edmunds. 2001. Social Learning in the Collaborative Management of Forests. Dalam: Wollenberg, E., D. Edmunds, L. Buck, J. Fox \& S. Brodt (penyunting). Social Learning in Community Forests. CIFOR, Bogor, Indonesia.

Buck, L., E. Wollenberg \& D. Edmunds. 2005. Pembelajaran Sosial dalam Pengelolaan KolaboratifHutan Komunitas: Pelajaran dariLapangan. Dalam: Wollenberg, E., D. Edmunds, L. Buck, J. Fox \& S. Brodt (penyunting). Pembelajaran Sosial dalam Pengelolaan Hutan Komunitas. Pustaka LATIN dan CIFOR, Bogor, Indonesia.

Carney, D. (penyunting). 1998. Sustainable Rural Livelihoods. What Contribution can We Make? Makalah dipresentasikan pada Konferensi Penasehat Sumber Daya Alam - DFID, Juli 1998. DFID, Londen, Inggris.

Dubois, O. 1998. Capacity to Manage Role Changes in Forestry. Introducing the 4R's Framework. IIED, Londen, Inggris.

Groot, A., N. van Dijk \& J. Jiggins. 2002. Three Challenges in the Facilitation of System-wide Change. Dalam: Leeuwis, C. \& R. Pyburn (penyunting). Wheelbarrows Full of Frogs: Social Learning in Rural Resources Management. International Research and Reflections. Hlm. 199-213. Koninklijke van Gorcum, Belanda.

Hartanto, H., C.M. Lorenzo, C. Valmores, L. Arda-Minas, E.M. Burton \& R. Prabhu. 2003. Learning Together. Responding to Change and Complexity to Improve Community Forests in the Philippines. CIFOR, Bogor, Indonesia.

Kolb, D.A. 1984. Experiential Learning: Experience as the Source of Learning and Development. Prentice-Hall, Englewood Cliffs, NJ, AS.

Kusumanto, T. Akan diterbitkan. Beyond Power Barriers: Political Learning in Jambi, Indonesia. Dalam: Guijt, I. (penyunting). Triggering Adaptation in Adaptive Collaborative Management: Learning through Collaborative Monitoring. CIFOR, Bogor, Indonesia; dan Resources for the Future, Washington DC, AS.

Maarleveld, M. \& C. Dangbégnon. 1999. Managing Natural Resources: A Social Learning Perspective. Dalam: Agriculture and Human Values 16:267-280.

McDougall, C. 2000. Draft Working Model of ACM (\#2), Local People, Devolution and Adaptive Co-Management Program, CIFOR (Feb). Draft 
internal. CIFOR, Bogor, Indonesia.

Ritchie, B., C. McDougall, M. Haggith \& N. Burford de Oliveira, N. 2001. Kriteria dan Indikator Kelestarian Hutan yang Dikelola oleh Masyarakat (Community Managed Forests). Pedoman Pendahuluan. CIFOR, Bogor, Indonesia.

Röling, N.G. \& J. Jiggins. 1998. The Ecological Knowledge System. Dalam: Röling, N.G. \& M.A.E. Wagemakers (penyunting). Facilitating Sustainable Agriculture. Cambridge University Press, Cambridge, Inggris.

Sarin, M. 1998. Who is Gaining? Gender and Equity Concerns in Joint Forest Management. Society for Promotion of Wasteland Development, New Delhi, India.

Steins, N.A. \& Edwards, V.M. 1999. Platforms for Collective Action in Multiple Use Common-pool Resources. Dalam: Agriculture and Human Values 16:241-255.

Wollenberg, E. bersama D. Edmunds \& L. Buck. 2001. Mengantisipasi Perubahan. Skenario sebagai Sarana Pengelolaan Hutan secara Adaptif. Suatu Panduan. CIFOR, Bogor, Indonesia. 
Center for International Forestry Research (CIFOR) adalah lembaga penelitian kehutanan internasional terdepan, yang didirikan pada tahun 1993 sebagai tanggapan atas keprihatinan dunia akan konsekuensi sosial, lingkungan dan ekonomi yang disebabkan oleh kerusakan dan kehilangan hutan. Penelitian CIFOR ditujukan untuk menghasilkan kebijakan dan teknologi untuk pemanfaatan dan pengelolaan hutan yang berkelanjutan, dan untuk meningkatkan kesejahteraan masyarakat di negara-negara berkembang yang bergantung kepada hutan tropis untuk kehidupannya. CIFOR adalah salah satu di antara 15 pusat Future Harvest di bawah Consultative Group on International Agricultural Research (CGIAR). Berpusat di Bogor, Indonesia, CIFOR mempunyai kantor regional di Brazil, Burkina Faso, Kamerun dan Zimbabwe, dan bekerja di lebih dari 30 negara di seluruh dunia.

\section{Donatur}

CIFOR menerima pendanaan dari pemerintah, organisasi pembangunan internasional, yayasan swasta dan organisasi regional. Pada tahun 2005, CIFOR menerima bantuan keuangan dari Australia, Asian Development Bank (ADB), Belgia, Brazil, Canada, China, Centre de coopération internationale en recherche agronomique pour le développement (CIRAD), Cordaid, Conservation International Foundation (CIF), European Commission, Finland, Food and Agriculture Organization of the United Nations (FAO), Ford Foundation, France, German Agency for Technical Cooperation (GTZ), German Federal Ministry for Economic Cooperation and Development (BMZ), Indonesia, International Development Research Centre (IDRC), International Fund for Agricultural Development (IFAD), International Tropical Timber Organization (ITTO), Israel, Italy, The World Conservation Union (IUCN), Japan, Korea, Netherlands, Norway, Netherlands Development Organization, Overseas Development Institute (ODI), Peruvian Secretariat for International Cooperation (RSCI), Philippines, Spain, Sweden, Swedish University of Agricultural Sciences (SLU), Switzerland, Swiss Agency for the Environment, Forests and Landscape, The Overbrook Foundation, The Nature Conservancy (TNC), Tropical Forest Foundation, Tropenbos International, United States, United Kingdom, United Nations Environment Programme (UNEP), World Bank, World Resources Institute (WRI) dan World Wide Fund for Nature (WWF). 
Di berbagai tempat di dunia ada kebutuhan yang kian mendesak untuk meningkatkan kualitas pengelolaan hutan. Kebutuhan ini dikarenakan adanya perbedaan kepentingan antara pemangku-pemangku kepentingan yang menggunakan tanah hutan (forestlands) dan sumber daya hutan (forest resources) yang sama. Situasi ini juga terjadi di Indonesia. Meskipun secara umum disepakati bahwa permasalahan ini harus diselesaikan melalui kerja sama antara para pemangku kepentingan yang bersaing, masih terdapat banyak pertanyaan tentang bagaimana kerja sama dapat dilakukan. Buku ini mencoba menjawab sebagian dari pertanyaan tersebut.

Buku ini membahas suatu pendekatan berbasis pembelajaran dalam mengembangkan kerja sama yang disebut adaptive collaborative management (ACM), yang bila diterjemahkan menjadi "pengelolaan bersama secara adaptif". Di dalam buku ini, digambarkan pengalaman Center for International Forestry Research (CIFOR) dan tiga mitra kerjanya, yakni Yayasan Gita Buana (YGB), Pusat Studi Hukum dan Kebijakan Otonomi Daerah (PSHK-ODA), dan Yayasan Padi dalam meneliti dan menerapkan ACM di dua tempat di Indonesia, yaitu di Sumatera dan Kalimantan. Para pembaca dapat membaca bagaimana sebuah tim peneliti aksi mendampingi kelompok dan lembaga lokal dalam menghadapi permasalahan sumber daya hutan di lokasi, apa keluarannya, dan apa implikasinya untuk penerapan ACM secara lebih luas di Indonesia. Buku ini memadukan pengalaman konkret tim dengan konsep-konsep yang lebih abstrak terkait dengan ACM yang berkembang ketika pendekatan ini diterapkan di lapangan.

Buku ini dapat digunakan sebagai acuan bagi para pendamping masyarakat, staf lapangan lembaga swadaya masyarakat (LSM), petugas lapangan instansi pemerintah, staf lapangan perusahaan kehutanan, dan pelatih. Mereka dan pembaca lainnya yang tertarik dapat menggunakan buku ini sebagai bahan acuan, "alat" dalam memfasilitasi kegiatan kelompok atau lembaga lokal, ataupun sekedar sebagai catatan pengalaman tim peneliti aksi dalam menerapkan pendekatan pengelolaan hutan yang berintikan pembelajaran. Buku ini juga dapat digunakan sebagai dasar pemikiran dalam mengembangkan metode, "alat", atau konsep pengelolaan hutan sembari mengaitkannya dengan praktek lapangan.
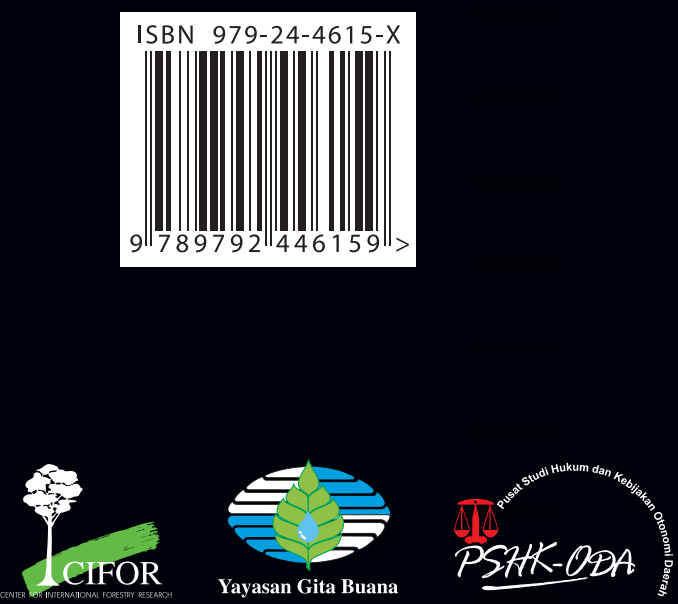

ADB

mi?

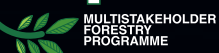

IDRC CRDI 